This is the Green Open Access version of: Georgiev, S., von Quadt, A., Heinrich, C. A., Peytcheva, I., Marchev, P., 2012. Time evolution of a rifted continental arc: integrated IDTIMS and LA-ICPMS study of magmatic zircons from the Eastern Srednogorie, Bulgaria. Lithos, vol. 154, pp. 53-67.

https://doi.org/10.1016/j.lithos.2012.06.020

\title{
Time evolution of a rifted continental arc: integrated ID-TIMS and LA-ICPMS study of magmatic zircons from the Eastern Srednogorie, Bulgaria
}

\author{
S. Georgiev1 ${ }^{*}$, A. von Quadt1 , C. A. Heinrich ${ }^{1,2}$, I. Peytcheva1,3, P. Marchev³ \\ ${ }^{1}$ Institute of Geochemistry and Petrology, ETH Zurich, Clausiusstrasse 25, CH-8092 \\ Zurich, Switzerland \\ 2Faculty of Mathematics and Natural Sciences, University of Zurich, Switzerland \\ ${ }^{3}$ Geological Institute, Bulgarian Academy of Sciences, Acad. G. Bonchev St., 1113 Sofia, \\ Bulgaria
}

${ }^{*}$ Corresponding author. Present address: Geological Survey of Norway, Trondheim and AIRIE Program, Department of Geosciences, Colorado State University, Fort Collins CO, USA

Telephone: ++1 970491 3816. Fax: +41 4463211 79. E-mail: georgiev@colostate.edu.

\begin{abstract}
Eastern Srednogorie in Bulgaria is the widest segment of an extensive magmatic arc that formed by convergence of Africa and Europe during Mesozoic to Tertiary times. Northward subduction of the Tethys ocean beneath Europe in the Late Cretaceous gave rise to a broad range of basaltic to more evolved magmas with locally associated $\mathrm{Cu}-\mathrm{Au}$ mineralization along this arc. We used U-Pb geochronology of single zircons to constrain the temporal evolution of the Upper Cretaceous magmatism and the age of basement rocks through which the magmas were emplaced in this arc segment. High precision isotope dilution - thermal ionization mass spectrometry (ID-TIMS) was combined with laser ablation - inductively coupled plasma mass spectrometry (LA-ICPMS) for spatial resolution within single zircon grains.

Three tectono-magmatic regions are distinguished from north to south within Eastern Srednogorie: East Balkan, Yambol-Burgas and Strandzha. Late Cretaceous magmatic activity started at $\sim 90 \mathrm{Ma}$ in the northernmost East Balkan region, based on stratigraphic evidence and limited geochronology, with the emplacement of minor shallow intrusions and volcanic rocks onto pre-Cretaceous basement. In the southernmost Strandzha region, magmatism was initiated at $\sim 86 \mathrm{Ma}$ with emplacement of gabbroic to dioritic intrusions and related dikes into metamorphic basement rocks that have previously been overprinted by Jurassic-Lower Cretaceous metamorphism. The Yambol-Burgas region is an extensional basin between the East Balkan and the Strandzha regions, which broadens and deepens toward the Black Sea further east and is filled with a thick pile of marine sediments and submarine extrusive volcanic rocks accompanied by coeval intrusions. This dominantly mafic magmatism in the intermediate Yambol-Burgas region commenced at $\sim 81 \mathrm{Ma}$ and produced large volumes of potassium-rich magma until $\sim 78$ Ma. These shoshonitic to ultrapotassic basaltic to intermediate magmas formed by differentiation of ankaramitic (high Ca) parental melts, produced from partial remelting
\end{abstract}


of amphibole clinopyroxenites upon interaction with subduction-modified mantle wedge melts, according to earlier petrological studies. This peak of dominantly extrusive activity in the Yambol-Burgas region extended into the Strandzha region further south, in the form of numerous tholeiitic, calc-alkaline and high-K intrusions emplaced in the same time period between 81 and $78 \mathrm{Ma}$.

Granitic rocks from exposed basement of Eastern Srednogorie zone are dated as Permian/Carboniferous ( 275-300 Ma). Zircons with similar ages occur in Upper Cretaceous rocks from the East Balkan and Strandzha regions, indicating local incorporation as xenocrysts. In contrast, magmatic rocks from the intermediate YambolBurgas region contain mostly Ordovician $(\sim 460 \mathrm{Ma})$ or older inherited zircons, suggesting a either a different basement history or, more likely, a different level of magma storage and crustal assimilation.

Integrating these geochronological results with a synthesis of the regional geology, we propose a two-stage geodynamic evolution for the Eastern Srednogorie segment of the Tethyan arc. The earlier stage of normal arc magmatism was driven by a southwardretreating, which formed the $\sim 90$ Ma calc-alkaline to high-K shallow intrusions and volcanics in the north (East Balkan), 87-86 Ma old tholeiitic and calc-alkaline intrusions in the south (Strandzha), and the voluminous 81-78 Ma old gabbroic to granitic intrusions with predominantly calc-alkaline to high-K composition throughout the Strandzha region. This stage continued westward into the Central Srednogorie zone, where the southward younging of calc-alkaline magmatism correlates well with an increased input of primitive mantle melts, indicating astenospheric incursion into a widening mantle wedge as a result of slab roll-back. The second stage proceeded in the Eastern Srednogorie zone only, where more extreme extension associated with the opening of the Black Sea back-arc basin led to the formation of an intra-arc rift in the Yambol-Burgas region, which now separates the East Balkan region from the Strandzha region. In this extensional environment, crustal thinning lead to decompression and increased heat flow, facilitating large-scale melting of lower crustal rocks and the formation of 81-78 Ma magmas. The unusual calcic composition of the parent magmas, their isotopic character and distinct xenocrystic population are consistent with a component of re-melting of hydrous lower-crustal cumulates, which probably formed in part during the first stage of the evolving arc.

Keywords: U-Pb zircon ages, ID-TIMS, LA ICPMS, Eastern Srednogorie arc, geodynamic evolution

\section{Introduction}

The Alpine orogeny in Europe formed from the long-term convergence between Africa and Europe and the associated consumption of Mesozoic oceanic basins through northward subduction of oceanic lithosphere beneath the European continent (Jankovic, 1997; Neubauer, 2002; Schmid et al., 2008; Burg, 2011). The Carpathian-Balkan segment of the Alpine orogen preserves geochemical evidence for these large-scale processes. The Apuseni-Banat-Timok-Srednogorie (ABTS) belt (Popov et al., 2002) is a more than 1000 $\mathrm{km}$ long belt of Upper Cretaceous calc-alkaline magmatic rocks with subduction-like geochemical signature. Presently, the ABTS belt extends from south Romania through east Serbia and across Bulgaria (Fig. 1) and hosts Europe's major $\mathrm{Cu}$-porphyry deposits (Mitchell, 1996; Berza et al., 1998; Heinrich and Neubauer, 2002).

Since the first plate-tectonic interpretations, the formation of the ABTS belt and the Srednogorie zone is attributed to the northward subduction of the Vardar oceanic branch of the Tethys Ocean beneath the Serbo-Macedonian-Rhodope massif and the Moesian promontory of the European continent (Dewey et al., 1973; Boccaletti et al., 1974; Aiello et al., 1977; Hsü et al., 1977; Dabovski et al., 1991; Jankovic, 1997; Ricou et al., 1998; Stampfli and Borel, 2004). Other models had considered the ABTS belt as an extensional structure in an epicontinental rift environment that formed as a result of post-collisional 
collapse and related astenospheric diapirism (Antonijevic et al., 1974; Popov, 1981; Popov, 1987). Neubauer (2002) suggested that some characteristics of the ABTS belt can be explained by progressive east to west tear-off of the subducted oceanic slab in a syncollisional regime.
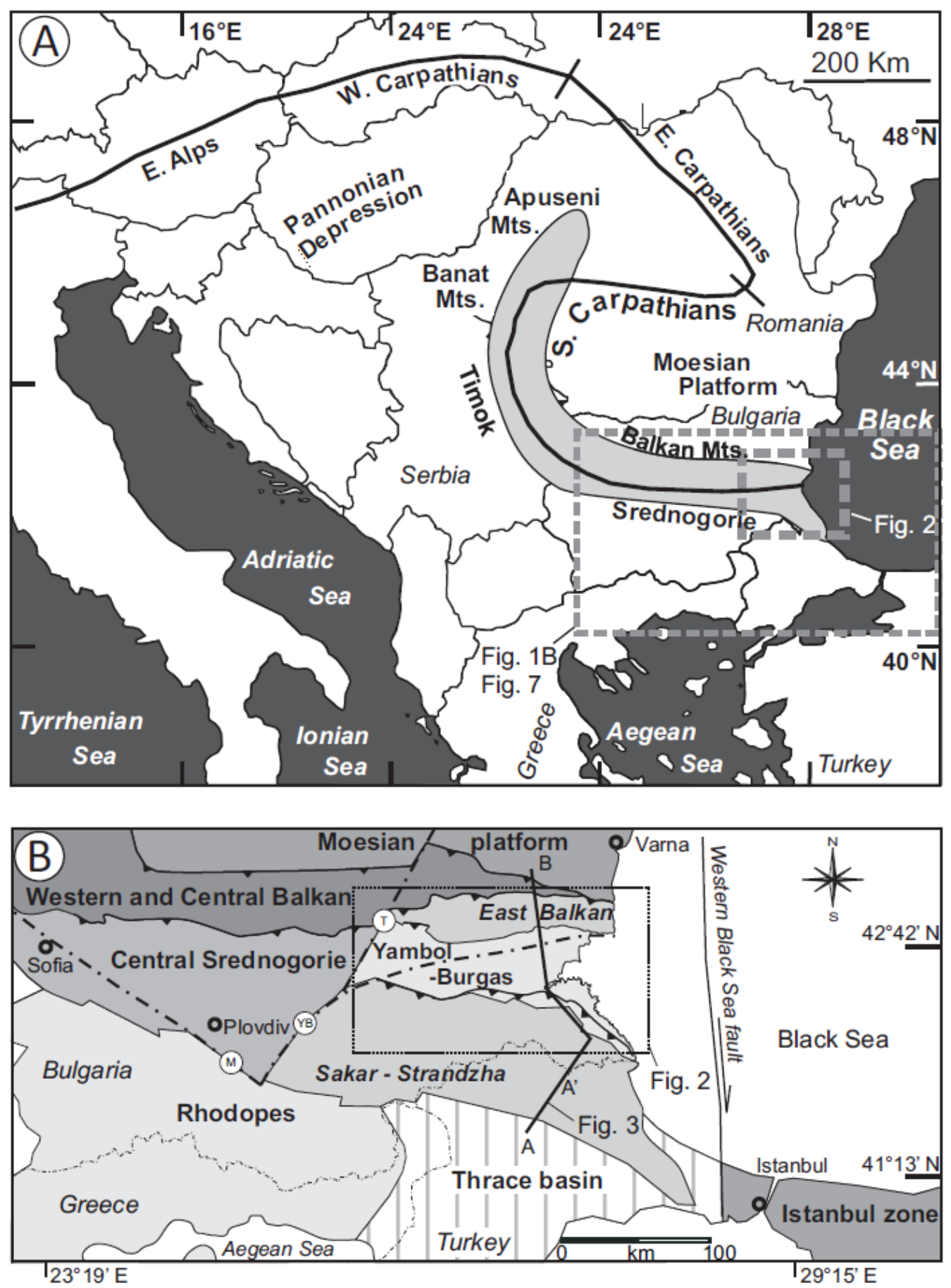

Figure 1. A) Sketch map of south-eastern Europe showing the location of Apuseni-Banat-Timok-Srednogorie Upper Cretaceous magmatic belt (gray field). Solid black line is the main front of the Alpine-CarpathianBalkan orogeny. Eastern Srednogorie zone occupies the easternmost parts of ABTS belt (grey dashed square). Modified after Ciobanu et al. (2002). B) Simplified tectonic map of Eastern Srednogorie zone (dotted rectangle) and adjacent units. Modified after Banks (1997), Dabovski et al. (2009-a), Ivanov (in press), Kamenov et al. (2003) and Okay et al. (2001). Location of Western Black Sea fault after Okay et al. (1994). Thick dash-dot-dash lines are major deep seated faults: YB- Yambol-Burgas fault (Dachev, 1988); M- Maritsa fault; T- Tvarditsa fault (Bončev, 1971). Additional details are shown in Fig. 7. 
Intense post-emplacement tectonics and erosion during the Alpine orogeny, combined with poor outcrops due to the low relief and young sediment infills, hinder a detailed geodynamic reconstruction of this area. High-precision geochronological dating provides a key tool to decipher the sequence of magmatic events in such terranes with complex post-emplacement history and poor preservation. High-precision U-Pb ID-TIMS zircon ages were reported for Late Cretaceous rocks from the Central Srednogorie zone (von Quadt et al., 2005). In the Panagyurishte transect, a $\mathrm{Cu}-\mathrm{Au}$-mineralized trend oriented obliquely to the main strike of the ABTS belt, magmatic ages gradually decrease from $92 \mathrm{Ma}$ in the north to $\sim 78 \mathrm{Ma}$ in the south. Re-Os molybdenite ages confirm the age progression of porphyry and epithermal $\mathrm{Cu}-\mathrm{Au}$ mineralization in this transect (Zimmerman et al., 2008). This trend is accompanied by changing igneous geochemistry, showing increasing mantle input from north to south (von Quadt et al., 2005; Kamenov et al., 2007). The combination of age and geochemical progressions is explained by a geodynamic model involving north-dipping subduction of Vardar oceanic lithosphere that experienced a progressive southward roll back of the subducting slab (von Quadt et al., 2005). In this model, steepening of the slab during rollback leads to an increased corner flow of upper lithospheric mantle and asthenospheric material, combined with extension of the upper plate.

The Eastern Srednogorie zone is the easternmost part of the ABTS belt, situated between the Central Srednogorie zone and the Black Sea (Figs. 1, 2). It is characterized by a presently thinner crust $(28-30 \mathrm{~km})$ compared to the rest of the Balkan Peninsula (e.g. crustal thickness in the adjacent Central Srednogorie zone is $\sim 40 \mathrm{~km}$; Dachev, 1988). Compared to the remaining ABTS belt, this zone hosts voluminous, mostly extrusive magmatism with unusually mafic and alkaline composition and a clear across-arc geochemical zonation (Georgiev et al., 2009 and references therein). The large volume and geochemical diversity of Eastern Srednogorie magmatism provides an excellent opportunity for detailed geochronological and geochemical studies to aid deciphering the evolution of the whole ABTS belt and the Balkan region. The position of Eastern Srednogorie zone next to the Central Srednogorie zone allows direct age and geochemical correlations within the Upper Cretaceous belt. Eastern Srednogorie zone is also the potential link of the ABTS belt with the Upper Cretaceous Pontide belt in Turkey to the southeast (Jankovic, 1997), and with the Black Sea basin to the east. The Black Sea is an extensional back-arc basin (Zonenshain and Le Pichon, 1986) that formed during an Aptian-Albian ( $\sim 125 \mathrm{Ma}$ to $100 \mathrm{Ma})$ main rifting phase, followed by intensive oceanic crust formation in spreading centers (Görür, 1988; Kaz'min and Tikhonova, 2006; Nikishin et al., 2001; Starostenko et al., 2004).

In this paper we aim to constrain the time evolution of the Late Cretaceous magmatism in the Eastern Srednogorie zone. We address the following main questions: 1) what is the precise age of magmatic rocks? 2) is there any along- or across strike age zonation within Eastern Srednogorie zone or correlations between ages and geochemistry of the magmatic rocks? 3) what is the age of the exposed basement intrusive rocks and is there any evidence for assimilation of basement rocks by the Upper Cretaceous magmas? 4) what is the geodynamic significance of the age data? To address these issues, we present and discuss an extensive dataset of U-Pb zircon ages from Eastern Srednogorie zone.

\section{Regional geology}

\subsection{Geology of Eastern Srednogorie zone}

. The basement of Eastern Srednogorie zone begins with Precambrian (?) high-grade metamorphic rocks, Paleozoic granites and greenschist facies rocks, followed by Permian clastics, Triassic carbonates and Lower-Middle Jurassic marine clastics and shales exposed in the present-day Strandzha Mountains (Figs. 2 and 3) (Chatalov, 1990; Dabovski et al., 2002; Gerdjikov, 2005). In the southeastern part of Strandzha these rocks are tectonically overlain by allochthonous Paleozoic and Triassic metasediments. In the East Balkan region, basement rocks are exposed in a narrow strip of Triassic carbonates 


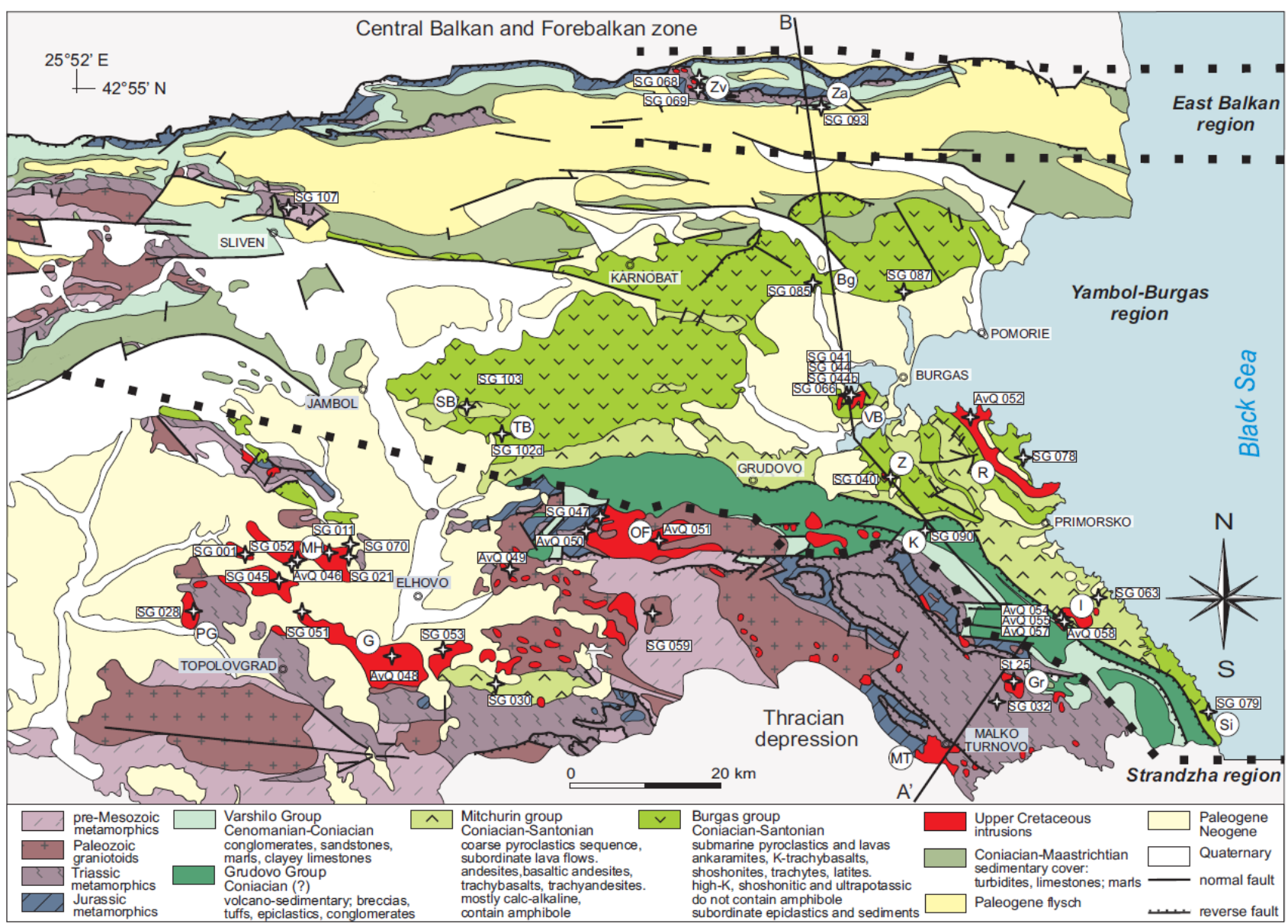

Figure 2. Geological map of Eastern Srednogorie zone, modified after Cheshitev and Kanchev (1989), showing U-Pb zircon ages of magmatic rocks (SG-and AvQ- numbered samples). Bold letters indicate confidently determined ages and italic letters are for tentative ages. Ages preceded with * are obtained by LA-ICPMS. The A'-B line marks the approximate location of a summary cross-section, presented on Fig. 3. Thick dotted lines mark the three magmatic regions within Eastern Srednogorie. White labeled circles are major magmatic centers as follows: in Strandzha region - PG - Polski Gradetz; MH - Monastery Heights; G - Granitovo; OF - Oman-Fakya; MT - Malko Turnovo; Gr - Gramatikovo; in Yambol-Burgas region - Si Silistar; I - Izgrev; K - Krushevetz; R - Rossen; Z - Zidarovo; VB - Vurli Brjag; TB - Tamarino Bakadzhik; SB - Sveti Spaski Bakadzhik; Bg - Bulgarovo; in East Balkan region - Za Zaimchevo; Zv - Zvezda. 
and flysch-like sediments, and Jurassic shales (e.g. Dabovski et al., 2002). The Upper Cretaceous succession begins with Cenomanian continental and shallow marine clastic sediments preserved along the border between the Strandzha Mountains and the YambolBurgas depression, and also in the East Balkan Mountains. During the Turonian, deeper marine shales and argillaceous carbonates were deposited in a deepening basin. In the Coniacian-Campanian the Yambol-Burgas depression was filled with a 5-6 km thick volcano-sedimentary succession (Nachev and Dimitrova, 1995a; Nachev and Dimitrova, 1995b). The East Balkan basin also records a thick Coniacian-Campanian deep marine sequence but lacks voluminous volcanic products. The Upper Cretaceous volcanosedimentary sequence is unconformably overlain by shallow-marine Maastrichtian carbonates in the Yambol-Burgas depression and by Paleogene and Neogene continental to shallow marine clastics and carbonate rocks in the East Balkan. Additional description of the geology of Eastern Srednogorie zone is given in Dabovski (1991), Dabovski et al. (2002), Georgiev et al. (2001) and Georgiev (2008).

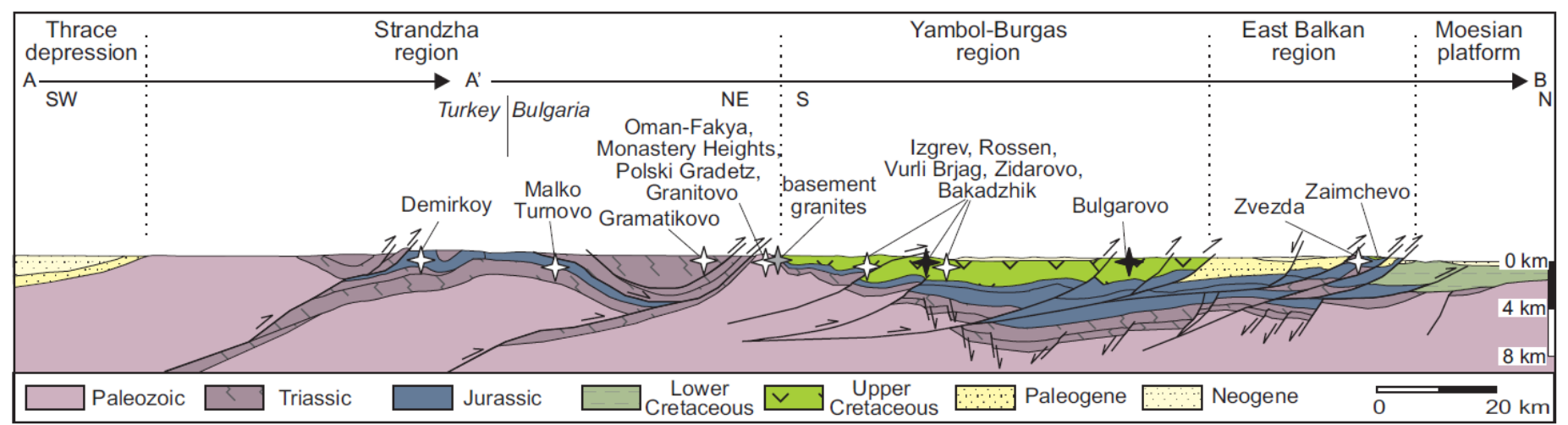

Figure 3. Schematic cross-section of Eastern Srednogorie zone along the A'-A-B line shown on Fig. 1b and Fig. 2, with approximate north-south location of dated Upper Cretaceous intrusions (white stars), Late Cretaceous lavas (black stars), and basement granitoids (gray stars). Cross-section based on tectonic interpretations and geophysical data from Georgiev et al. (2001) and Banks (1997).

\subsection{Magmatism}

More than 90 intrusions and volcanic centers are described in the Eastern Srednogorie zone (Popov, 1981; Nachev and Nachev, 2003), comprising more than 60 area percent of the exposed magmatic rocks of Cretaceous age in the whole Srednogorie zone (Stanisheva-Vassileva, 1989). In contrast to most of the ABTS magmatic belt, where calcalkaline rocks of intermediate composition prevail, the Eastern Srednogorie zone is characterized by a large geochemical variability and a predominance of mafic to intermediate over felsic magmas. Primitive nepheline-normative ankaramites have been reported among the mafic lavas (Georgiev et al., 2009; Marchev et al., 2009). Abundant major element geochemical data show that the mafic and intermediate magmatism in Eastern Srednogorie zone covers the entire spectrum of chemical series observed in volcanic arcs: from tholeiitic through calc-alkaline to alkaline (shoshonitic) compositions (Stanisheva-Vassileva, 1980; Popov, 1981; Stanisheva-Vassileva, 1989; Georgiev et al., 2009). An increase of the $\mathrm{K}_{2} \mathrm{O}$ content of the rocks from south to north has been interpreted as evidence for the progressive deepening of the melt-generation regions, consistent with a northward subduction of the Vardar Ocean plate below the European platform (Stanisheva-Vassileva, 1980; Stanisheva-Vassileva, 1989; Dabovski et al., 1991). However, new geochemical data from the northernmost magmatic products in Eastern Srednogorie zone reveals a complex zonation with more evolved calc-alkaline magmas to the south and north and more mafic shoshonitic to ultra-potassic magmas in the center (Georgiev et al., 2006; Georgiev, 2008; Georgiev et al., 2009). Four magmatic regions are traditionally distinguished within Eastern Srednogorie zone: Strandzha, Yambol-Burgas, North Burgas and East Balkan from south to north. The North Burgas region, which has been considered a back-arc rift (Dabovski et al., 1991; Georgiev et al., 2001), shows similar 
major and trace element characteristics and isotopic fingerprints as the Yambol-Burgas region (Marchev et al., 2009; Georgiev et al., 2009). Based on these similarities, Georgiev et al., (2009) proposed a common origin for the magmatic rocks from the Yambol-Burgas and the North Burgas regions. Here, we adopt this view and merge the two regions into one extended region named Yambol-Burgas region (Figs. 2 and 3).

The Yambol-Burgas and Strandzha regions host most of the Upper Cretaceous magmatic products in the Eastern Srednogorie zone, whereas only few small outcrops are known in the East Balkan region (Georgiev et al., 2009). Magmatic rocks from the Strandzha and East Balkan regions are mostly calc-alkaline to high-K intrusions containing hydrous phases, whereas in the central Yambol-Burgas region they are dominantly basic to intermediate submarine shoshonitic volcanic rocks that rarely contain hydrous minerals (Georgiev et al., 2009). Stratigraphic relations constrain the magmatism in Eastern Srednogorie zone as broadly Turonian-Campanian (from $\sim 94$ to $\sim 70 \mathrm{Ma}$ ) and the peak of the magmatic activity is considered as Coniacian-Campanian, from $\sim 90$ to $\sim 70 \mathrm{Ma}$ (e.g. Dabovski et al., 1991; Georgiev et al., 2001). Prior to this study, available radiometric data consisted exclusively of K-Ar ages of whole-rocks or mineral separates varying between 130 and $50 \mathrm{Ma}$ (summarized in von Quadt et al., 2005). The exposed basement rocks in this zone were not dated radiometrically.

\subsection{Metallogeny}

The ABTS belt is the most important metallogenic belt in the Alpine-BalkanideCarpathian-Dinaride region (Heinrich and Neubauer, 2002), hosting major porphyry style and high-sulphidation $\mathrm{Cu} \pm \mathrm{Au}$ polymetallic and carbonate-replacement deposits. In contrast to the Central Srednogorie and Timok parts of the ABTS belt that host the economically most important deposits, magmatism and associated hydrothermal activity in the Eastern Srednogorie zone produced mostly $\mathrm{Fe} \pm \mathrm{Cu}$ skarn deposits and mesothermal- to epithermal $\mathrm{Cu}-\mathrm{Au}$ polymetallic vein deposits with smaller size. The different chemical composition and depth of magma emplacement predetermined the contrasting mineralization style between the Strandzha and Yambol-Burgas regions of Eastern Srednogorie zone. In the Strandzha region, emplacement of tholeiitic to calcalkaline gabbro-dioritic intrusions in Triassic carbonates formed the Fe-skarn magnetiterich deposit of Krumovo in the Monastery Heights and the Cu-skarn deposits near Malko Turnovo (Fig. 2), as well as numerous smaller occurrences and showings, including orthomagmatic Fe-Ti mineralizations. In the Yambol-Burgas region, ore deposits of mesothermal to epithermal $\mathrm{Cu}$-polymetallic vein type are related to volcano-plutonic systems with shoshonitic and high-K magmatism (Popov, 1996), including the Zidarovo, Vurli Brjag, Rossen and Tamarino Bakadzhik ore fields (Fig. 2) that formed at shallower crustal depth compared to the skarn deposits in the Strandzha region.

\section{Sample selection and analytical techniques}

We sampled fresh to minimally altered intrusive and extrusive rocks, selecting samples where field relations indicated clear temporal succession of emplacement. Samples were crushed and ground, and mineral concentrates were purified by magnetic and density separation (Wilfley table and heavy liquids) techniques. Individual zircons were further selected using a binocular microscope.

\subsection{Conventional high-precision TIMS single-grain dating}

Prior to analyses, most single zircon crystals were pre-treated to remove zircon domains prone to post-crystallization $\mathrm{Pb}$ loss. The majority of the analyzed zircons $(\sim 60 \%)$ were air-abraded for several hours in the presence of pyrite grains following the method of Krogh (1982). The chemical abrasion technique of Mattinson (2005) was tested on 20\% of the grains, and the remaining $20 \%$ of zircon grains were analyzed without any pretreatment (unabraded). All zircon grains were separately cleaned, spiked with a ${ }^{205} \mathrm{~Pb}-$ ${ }^{235} \mathrm{U}$ tracer and digested following procedures in Krogh (1973). After anion exchange column chemistry, both $\mathrm{Pb}$ and $\mathrm{U}$ were loaded on an outgassed Re filament. Isotope ratios 
were determined in ETH-Zurich on a Finnigan MAT 262 mass-spectrometer, using electron multiplier for most samples. Further details are given by Georgiev (2008) and von Quadt et al. (2011). The Pb MacDat Excel spreadsheet (Coleman, unpublished), which incorporates error propagation equations of Ludwig (1980), was used for data reduction. We used a mass fractionation of $0.11 \pm 4.6 \% / \mathrm{AMU}$ for $\mathrm{Pb}$ measured with Faraday cups, and $0.13 \pm 4.0 \% / \mathrm{AMU}$ for $\mathrm{Pb}$ measured with the electron multiplier, determined from multiple analyses of the NBS982 $\mathrm{Pb}$ standard. Total procedural blank was on average 0.8 $\mathrm{pg} \mathrm{Pb}$ and $0.01 \mathrm{pg} \mathrm{U}$ with a $\mathrm{Pb}$ isotopic composition of ${ }^{206} \mathrm{~Pb} /{ }^{204} \mathrm{~Pb}=17.8 \pm 0.29,{ }^{207} \mathrm{~Pb} /{ }^{204} \mathrm{~Pb}$ $=15.47 \pm 0.30,{ }^{208} \mathrm{~Pb} /{ }^{204} \mathrm{~Pb}=37.35 \pm 0.80$. Concordia plots, weighted averages, and probability density plots were constructed with the Isoplot 3.00 software (Ludwig, 1991; Ludwig, 2003).

\section{2. $\quad$ Zircon imaging and LA-ICPMS single grain dating}

The largest and inclusion free grains were handpicked, mounted in epoxy resin and polished to expose grain cores. Chips were then carbon-coated for electron-microscope imaging. Backscattered electron (BSE) and cathode-luminescence (CL) images were acquired at ETH Zurich using a CamScan CS44LB scanning electron microscope. After imaging, chips were re-polished to remove coating and cleaned. Laser dating was performed at ETH Zurich using a $193 \mathrm{~nm}$ ArF excimer laser (Lambda Physik) coupled to an Elan 6100 DRC ICP-MS instrument (Perkin Elmer). More detailed description of the instrumentation is given in Günther et al. (1998) and Heinrich et al. (2003). Ablation spots were chosen based on CL and BSE images and transmitted-light petrography. Energy densities of 20 to $25 \mathrm{~J} / \mathrm{cm}^{2}$ and laser pulse frequency of $10 \mathrm{~Hz}$ were used. A typical analytical block consisted of 20 measurements (3 NIST 610 standards at the beginning, 14 zircons, and 3 standards at the end). Additional details are given in Georgiev (2008).

The reported ages and errors were calculated using an in-house Excel-based spreadsheet (Georgiev, 2008). Data were corrected for laser-induced elemental fractionation using the intercept of the linear regression through the raw ratios as described in Chang et al. (2006). Mass discrimination was controlled and corrected by applying an external correction method. First, we measured NIST 610 as an unknown, corrected the raw data for laser induced fractionation, and used numerous point analyses of the zircon standards Plesovice (Slama et al., 2008) and 91500 (Wiedenbeck et al., 1995) for external mass-bias correction. The resulting NIST 610 values of ${ }^{206} \mathrm{~Pb} /{ }^{238} \mathrm{U}=0.21938,{ }^{207} \mathrm{~Pb} /{ }^{235} \mathrm{U}=89.53417$ and ${ }^{208} \mathrm{~Pb} /{ }^{232} \mathrm{Th}=0.44836$ were reproducible and independent of crater diameters between 20 to 70 microns provided that crater depth stayed smaller than the crater radius. These calculated NIST 610 values thus include a correction for any matrix dependence between zircon and silicate glass, and were subsequently used for external calibration of unknown zircon samples. This calibration procedure has the advantage of better counting-statistical reproducibility of the comparatively Pb-rich (426 ppm $\mathrm{Pb}$ ) NIST 610. The calculated U-Th-Pb isotope ratios differ from published TIMS values for NIST 610 (Stern and Amelin, 2003), but are close to the U-Th-Pb isotope ratios derived from concentrations and isotope abundances in NIST 610 (data from Rocholl et al., 2000). The amount of common $\mathrm{Pb}$ was calculated from ${ }^{204} \mathrm{Hg}$-corrected ${ }^{204} \mathrm{~Pb}$ intensities. ${ }^{201} \mathrm{Hg}$ or ${ }^{202} \mathrm{Hg}$ masses were monitored and used to calculate ${ }^{204} \mathrm{Hg}$ counts, which were subtracted from the ${ }^{204} \mathrm{~Pb}$ counts. Following Hg-correction, the ${ }^{206} \mathrm{~Pb} /{ }^{238} \mathrm{U}$ age calculated from background and mass-bias corrected ${ }^{206} \mathrm{~Pb} /{ }^{238} \mathrm{U}$ ratio was used to estimate the initial common $\mathrm{Pb}$ composition from the Stacey and Kramers (1975) model for Pb isotopic evolution through time. Using this composition, the fraction of $206 \mathrm{~Pb},{ }^{207} \mathrm{~Pb},{ }^{208} \mathrm{~Pb}$ proportional to the measured $\mathrm{Hg}$-corrected ${ }^{204} \mathrm{~Pb}$ was subtracted from the calculated ${ }^{206} \mathrm{~Pb} /{ }^{238} \mathrm{U},{ }^{207} \mathrm{~Pb} /{ }^{235} \mathrm{U}$ and ${ }^{208} \mathrm{~Pb} /{ }^{232} \mathrm{Th}$ ratios.

\subsubsection{Error propagation, precision and accuracy}

The reported error of individual laser dates includes two components. In addition to the counting error on the intercept regression, we included the $2 \sigma$ errors from the first three and the last three standard measurements by standard error propagation. The accuracy 
of our LA-ICPMS U-Pb method was estimated continually by analyzing zircon standards Plesovice and 91500 as unknowns, bracketed by NIST 610 silicate glass standard and using the calibrated NIST values for mass bias correction. The long-term average for Plesovice zircon over several sessions gives an age of $338.3 \pm 2.5 \mathrm{Ma}$ (weighted average ${ }^{206} \mathrm{~Pb} /{ }^{238} \mathrm{U}, \mathrm{n}=13, \mathrm{MSWD}=2.9$ ), which is in agreement with the ID-TIMS age of $337.13 \pm 0.37$ (Slama et al., 2008). Our ${ }^{206} \mathrm{~Pb} /{ }^{238} \mathrm{U}$ LA-ICPMS age for the 91500 standard is 1058.4 $\pm 9.4 \mathrm{Ma}(\mathrm{n}=15, \mathrm{MSWD}=2.5)$, which overlaps within errors the 91500 ID-TIMS age of $1065 \pm 0.4$ Ma (Wiedenbeck et al., 1995).

\section{Results}

Zircon grains from 43 samples were analyzed in this study, 39 from Cretaceous magmatic rocks and 4 from the exposed pre-Cretaceous basement. Results from single-grain U-Pb ID-TIMS dating are presented in Appendix 1; LA-ICPMS U-Pb data are given in Appendix 2. The North-Burgas area is presented as a separate region in the electronic supplement for easier comparison with some published literature. However, this area is considered as part of the Yambol-Burgas region in the discussion, as noted earlier. To better constrain the crystallization age of a rock and minimize subjectivity, we followed several criteria for age calculations. We gave preference to ID-TIMS ages over LA-ICPMS data, where sufficient numbers of zircon grains were analyzed by both methods. Depending on sample population and number of studied grains, concordia ages were preferred rather than upper - or lower intercept ages or weighted averages of ${ }^{206} \mathrm{~Pb} /{ }^{238} \mathrm{U}$ ages. Intercept ages and weighted ${ }^{206 \mathrm{~Pb}} /{ }^{238} \mathrm{U}$ ages were filtered based on the number of grains and MSWD values that indicate the overlap and scatter of data points. Although these general rules were taken into account, every sample has its own specifics. The dated samples are subdivided into two categories based on our confidence in the calculated crystallization age: a) samples with high-confidence crystallization ages; b) samples with tentative ages. The tentative ages reflect either the small number of analyzed grains or the large uncertainty, but these are geologically meaningful ages; additional analyses are likely to better constrain the age. In some rocks, however, the number of studied grains and/or the complex U-Pb systematic did not allow calculations of reliable U-Pb crystallization ages. Discussion of U-Pb zircon age data for individual rock samples is given in Appendix 3 and summarized below. BSE and CL zircon images are given together with the location of the LA-ICPMS dating in Appendix 4.

\section{1. $\quad$ Age of Upper Cretaceous magmatic rocks}

\subsubsection{U-Pb crystallization ages}

High-confidence crystallization ages were obtained for 14 Upper Cretaceous rocks (Table 1). From these, ten are from the Strandzha region and four from the Yambol-Burgas region. Most high-confidence ages are for intrusive rocks, with the exception of samples SG 021 (dike) and SG 103 (lava flow). For nine samples the calculated crystallization ages are tentative. The $\mathrm{U}-\mathrm{Pb}$ ages range from $\sim 87 \mathrm{Ma}$ to $\sim 78 \mathrm{Ma}$, constraining the duration of the Late Cretaceous magmatic activity to ca. 9 Ma (Fig.2, Fig. 4). Most rocks from all regions crystallized between 81.23 and $78.00 \mathrm{Ma}$. A second, clearly visible age group comprises intrusive and dike rocks from Strandzha region (from Monastery Heights and Gramatikovo plutons) with ages ranging from 87.1 to 86.2 Ma. Additionally, a dioritic intrusion from Silistar has a slightly younger age near $76 \mathrm{Ma}$, but the age errors are large and overlap the $78 \mathrm{Ma}$ event.

The ages within a given magmatic center vary within a narrow range and generally overlap within their errors (e.g. Izgrev pluton; Granitovo pluton). The only notable exception is the Monastery Heights pluton in the Strandzha region, where two distinct magmatic events with high-confidence ages of 86 (diorite) and 81-79 Ma (gabbro, basalt and granite) are detected. This age spread is too large to be explained with the presence of a long-lived magma chamber and indicate that the Monastery Heights intrusion was 
Table 1. Calculated crystallization ages for Late Cretaceous rocks from Eastern Srednogorie zone.

\begin{tabular}{|c|c|c|c|c|c|c|c|c|c|c|c|c|}
\hline Sample & Region & Center & Type & Method & $\mathbf{N}$ & $\mathbf{N}^{*}$ & Age, $\mathrm{Ma}$ & Error, Ma & Age type & MSWD & Type of error & Category \\
\hline SG 085 & Yambol-Burgas & Bulgarovo & $\mathrm{v}$ & ID-TIMS & 3 & 1 & 79.90 & 3.20 & $\mathrm{C}$ & & $95 \%$ conf. & tentative \\
\hline SG 103 & Yambol-Burgas & Bakadzhik & $\mathrm{v}$ & ID-TIMS & 1 & 1 & 80.08 & 3.10 & $\mathrm{C}$ & & $95 \%$ conf. & tentative \\
\hline SG 102d & Yambol-Burgas & Bakadzhik & $\mathrm{v}$ & ID-TIMS & 3 & 1 & 79.59 & 3.00 & $\mathrm{C}$ & & $95 \%$ conf. & tentative \\
\hline SG 044 & Yambol-Burgas & Vurli Brjag & $\mathrm{i}$ & ID-TIMS & 7 & 4 & 78.98 & 0.31 & LI & 1.5 & $95 \%$ conf. & confident \\
\hline SG 044b & Yambol-Burgas & Vurli Brjag & $\mathrm{v}$ & ID-TIMS & 4 & 1 & 79.46 & 0.60 & $\mathrm{C}$ & & 2 sigma & tentative \\
\hline SG 040 & Yambol-Burgas & Zidarovo & $\mathrm{i}$ & LA-ICPMS & 9 & 4 & 78.00 & 2.80 & WTD & 1.3 & $95 \%$ conf. & tentative \\
\hline AvQ 052 & Yambol-Burgas & Rossen & $\mathrm{i}$ & ID-TIMS & 2 & 2 & 79.62 & 0.47 & $\mathrm{C}$ & & $95 \%$ conf. & confident \\
\hline AvQ 057 & Yambol-Burgas & Izgrev & $\mathrm{i}$ & ID-TIMS & 13 & 2 & 79.93 & 0.22 & $\mathrm{C}$ & & 2 sigma & confident \\
\hline AvQ 054 & Yambol-Burgas & Izgrev & i & ID-TIMS & 5 & 4 & 81.23 & 0.17 & $\mathrm{C}$ & & 2 sigma & confident \\
\hline SG 079 & Yambol-Burgas & Silistar & $\mathrm{i}$ & LA-ICPMS & 5 & 4 & 76.20 & 1.60 & WTD & 0.71 & $95 \%$ conf. & tentative \\
\hline SG 028 & Strandzha & Polski Gradetz & $\mathrm{i}$ & ID-TIMS & 7 & 1 & 78.27 & 0.18 & $\mathrm{C}$ & & 2 sigma & confident \\
\hline SG 001 & Strandzha & Monastery Heights & $\mathrm{i}$ & LA-ICPMS & 5 & 3 & 80.60 & 1.10 & $\mathrm{C}$ & & 2 sigma & confident \\
\hline AvQ 046 & Strandzha & Monastery Heights & i & ID-TIMS & 4 & 1 & 79.10 & 0.17 & $\mathrm{C}$ & & 2 sigma & tentative \\
\hline SG 052 & Strandzha & Monastery Heights & $\mathrm{d}$ & ID-TIMS & 5 & 2 & 78.83 & 0.17 & $\mathrm{C}$ & & 2 sigma & confident \\
\hline SG 011 & Strandzha & Monastery Heights & $\mathrm{i}$ & ID-TIMS & 5 & 3 & 86.36 & 0.14 & $\mathrm{C}$ & & 2 sigma & confident \\
\hline SG 021 & Strandzha & Monastery Heights & $\mathrm{d}$ & ID-TIMS & 4 & 3 & 78.95 & 0.30 & $\mathrm{C}$ & & $95 \%$ conf. & confident \\
\hline SG 053 & Strandzha & Chernozem-Razdel & $\mathrm{i}$ & LA-ICPMS & 8 & 3 & 79.91 & 2.00 & tuffzirc & & $75 \%$ conf. & tentative \\
\hline SG 045 & Strandzha & Granitovo & i & ID-TIMS & 4 & 1 & 79.66 & 0.14 & $\mathrm{C}$ & & 2 sigma & confident \\
\hline AvQ 048 & Strandzha & Granitovo & $\mathrm{i}$ & ID-TIMS & 15 & 6 & 79.94 & 0.14 & WTD & 2.2 & $95 \%$ conf. & confident \\
\hline AvQ 050 & Strandzha & Oman-Fakya & i & ID-TIMS & 3 & 3 & 80.98 & 0.32 & $\mathrm{C}$ & & $95 \%$ conf. & confident \\
\hline AvQ 051 & Strandzha & Oman-Fakya & $\mathrm{i}$ & ID-TIMS & 6 & 3 & 79.77 & 0.30 & $\mathrm{C}$ & & $95 \%$ conf. & confident \\
\hline SG 032 & Strandzha & Gramatikovo? & $d$ & ID-TIMS & 3 & 1 & 85.23 & 3.60 & $\mathrm{C}$ & & $95 \%$ conf. & tentative \\
\hline ST 25 & Strandzha & Gramatikovo & $\mathrm{i}$ & ID-TIMS & 4 & 4 & 86.84 & 0.29 & $\mathrm{C}$ & & $95 \%$ conf. & confident \\
\hline
\end{tabular}

Abbreviations: $v$ - volcanic; $d$ - dike; I - intrusive; $N$ - number of grains analyzed from the sample with the reported method; $N^{*}-$ the number of grains, used for the calculation of the crystallization age; C - concordia; WTD - weighted average ${ }^{206} \mathrm{~Pb} /{ }^{238} \mathrm{U}$ age; LI - lower intercept; tuffzirc - age, calculated with the zircon age extraction algorithm of ISOPLOT. 
generated in at least two separate magmatic pulses. The two pulses, however, have similar $\mathrm{Sr}$ and $\mathrm{Pb}$ whole-rock isotopes (Georgiev et al., 2009).

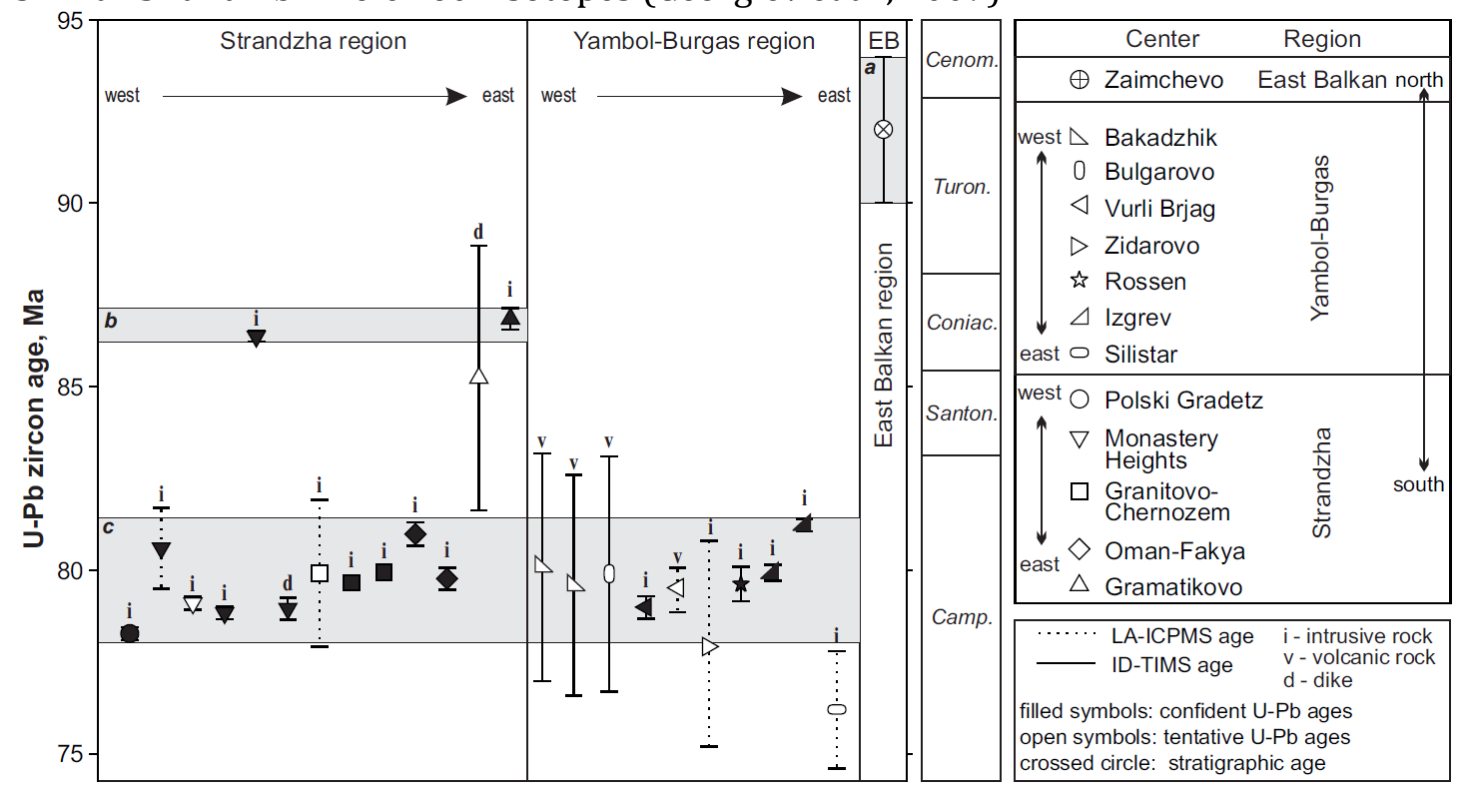

Figure 4. High-confidence and tentative U-Pb crystallization ages of Upper Cretaceous magmatic rocks from Eastern Srednogorie zone and corresponding 2 sigma errors. Stratigraphic constraints for a Late Cenomanian-Early Turonian age (Kunchev, 1966; Dabovski et al., 2009b) are used to plot the East Balkan magmatism at $92 \pm 2 \mathrm{Ma}$. Ages for the Upper Cretaceous stage boundaries taken from Ogg et al. (2008). Gray fields delineate the three major magmatic events discussed: $(a)$ the $~ 92$ Ma event observed only in the East Balkan, ages are based on biostratigraphy; $(b)$ the 87.1-86.2 Ma event based on high-confidence U-Pb ID-TIMS zircon ages, observed only in the Strandzha region; and (c) the 81.4-78.0 Ma event based on high-confidence $\mathrm{U}-\mathrm{Pb}$ ID-TIMS zircon ages, observed in the Strandzha and Yambol-Burgas regions.

\subsubsection{Distribution of $U$-Pb single zircon ages}

Histograms of individual ${ }^{206} \mathrm{~Pb} /{ }^{238} \mathrm{U}$ zircon ages show a prominent peak at 80 - $79 \mathrm{Ma}$ (Fig. $5 a$ ), especially if the data of high confidence (TIMS data and concordant LA-ICPMS ages) are considered. This 80-79 Ma peak is particularly pronounced in the Strandzha region, where the number of dated grains is largest. Even though LA-ICPMS ages in Strandzha are generally more dispersed, their distribution matches ID-TIMS ages with a peak between 82 and $77 \mathrm{Ma}$. A second notable age peak at 87-85 Ma is defined by both ID-TIMS and LAICPMS data.

Similar to the Strandzha region, the most prominent peak in the Yambol-Burgas region is also at 80-79 Ma, with most of the zircons ranging from 82 to $77 \mathrm{Ma}$. However, the 87-85 Ma peak is not observed in the Yambol-Burgas region. Additionally, there is an indication of a $71 \mathrm{Ma}$ event in the Yambol-Burgas region, defined by LA-ICPMS data, but this peak is not confirmed by ID-TIMS data. These younger ages may reflect $\mathrm{Pb}$ loss from zircons, undetected with the lower precision of LA data (larger error ellipses do not allow unambiguous distinction between concordant and slightly discordant grains). Few even younger LA-ICPMS zircon ages in the Strandzha and Yambol-Burgas regions are also attributed to $\mathrm{Pb}$ loss. The few grains showing ages older than $86 \mathrm{Ma}$ from both Strandzha and Yambol-Burgas regions are not sufficient indication for an older magmatic event and probably reflect the presence of minor inherited components.

The number of studied rocks and/or analyzed zircons from the East Balkan region is insufficient for a detailed interpretation. Three rocks have zircons with ${ }^{206} \mathrm{~Pb} / 238 \mathrm{U}$ ages ranging from 45 to $98 \mathrm{Ma}$, with no overlap within single samples.

In summary, zircon $\mathrm{U}-\mathrm{Pb}$ age data unequivocally shows that the peak of the Late Cretaceous magmatic activity in the Eastern Srednogorie zone was from 82 until $77 \mathrm{Ma}$. Abundant magmatism within this time interval is observed in the southernmost Strandzha and the intermediate Yambol-Burgas regions. Few rocks from the Strandzha region are older (87-85 Ma). The radiometric age of the magmatism in East Balkan region 
remains undetermined. However, stratigraphic relations constrain the age of East Balkan magmatism to ca. $90 \mathrm{Ma}$ (see below).
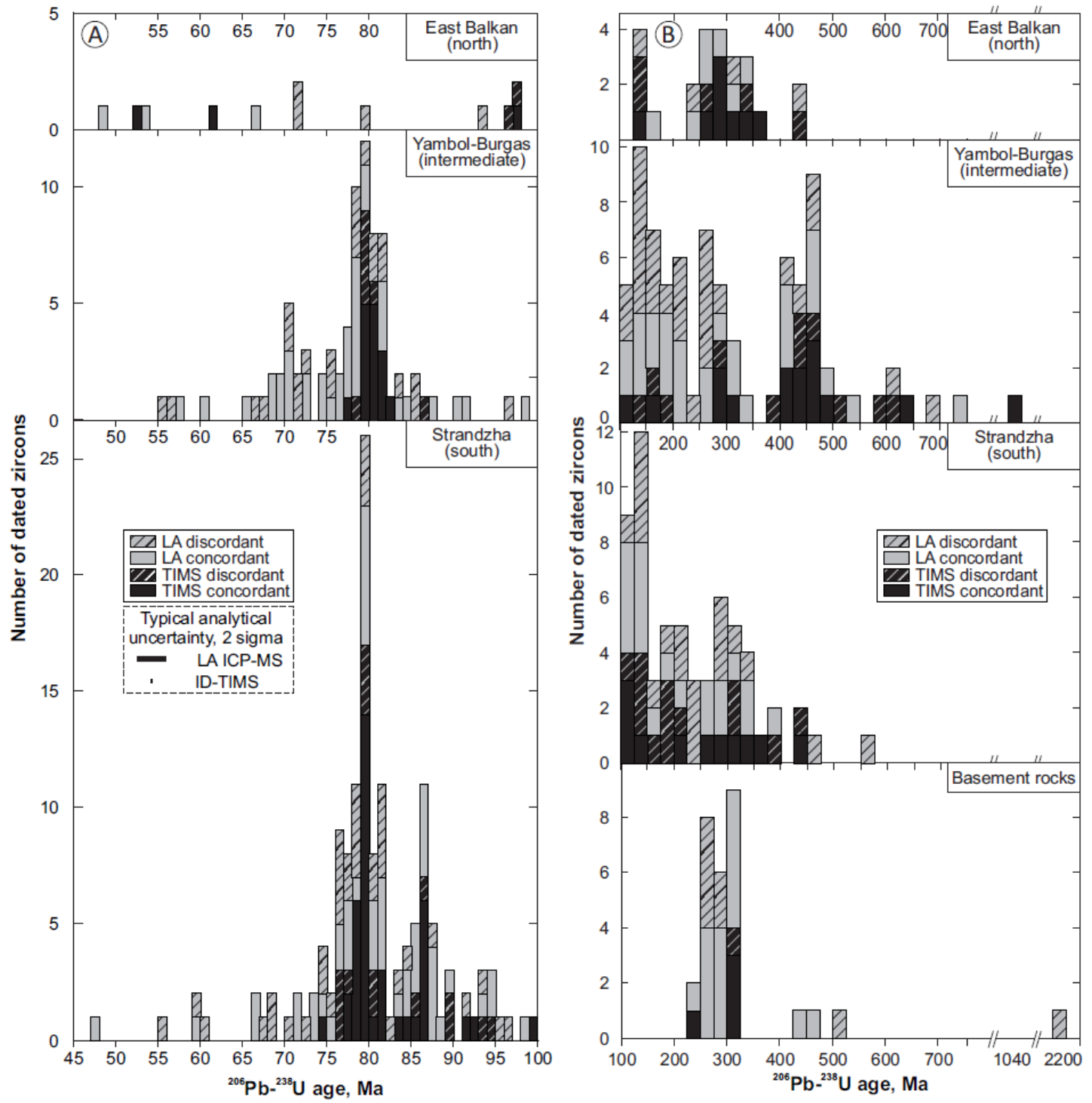

Figure 5. Histograms of single grain 206 Pb/238U ages of all studied zircons. A) zircons younger than $100 \mathrm{Ma}$. Bin width is $1 \mathrm{Ma}$; B) zircons older than $100 \mathrm{Ma}$. Bin width is $25 \mathrm{Ma}$. For plotting purposes, analyses that overlap the Concordia curve are classified and plotted as concordant. This approach avoids subjective decisions on the concordance of the grains, but it does not take into account the size of the error ellipse, or sometimes the unproportionally large error of the $207 \mathrm{~Pb} / 235 \mathrm{U}$ age compared to the $206 \mathrm{~Pb} / 238 \mathrm{U}$ age.

\section{2. $\quad$ Age of basement rocks}

$\mathrm{U}-\mathrm{Pb}$ crystallization ages of three basement rocks from the Eastern Srednogorie zone range from 301 to $274 \mathrm{Ma}$ (Table 2). These ages are similar to published zircon evaporation $\mathrm{Pb}$ ages for basement granites from the Turkish part of Strandzha: $271 \pm 2 \mathrm{Ma}$ for Kirklareli metagranite, $271 \pm 11$ Ma for Kula metagranite and 309 \pm 24 Ma for Uskup metagranite (Okay et al., 2001).

\subsection{Age of inherited zircons}

The studied rocks contain variable amounts of inherited older zircons in the form of xenocrysts and/or xenocrystic cores overgrown by Late Cretaceous rims (Appendix 3, Appendix 4). The distribution of single-grain ${ }^{206} \mathrm{~Pb} /{ }^{238} \mathrm{U}$ ages of inherited zircons is shown on Fig. 5b. Zircons with 120-170 Ma ages are detected in all regions. All regions also contain a peak at $\sim 300 \mathrm{Ma}$, but only the central Yambol-Burgas region has a prominent peak at $\sim 460 \mathrm{Ma}$. Rare older zircon ages (550-1050 Ma) are detected only in this central region, whereas concordant Upper Cretaceous inherited zircons (80-92 Ma and 
discernibly older than the host rock) are found only in Granitovo and Monastery Height intrusions in the Strandzha region. Geographically, most samples with inherited zircons are from the western and central parts of the Strandzha region and from the southeastern part of the Yambol-Burgas region (Fig. 6). This could represent local variations in the basement, but may also result from the unevenly distributed sampling and the different number of studied grains from different samples.

Table 2. Calculated crystallization ages of exposed basement rocks from Eastern Srednogorie zone.

\begin{tabular}{|c|c|c|c|c|c|c|c|c|c|c|c|}
\hline $\begin{array}{c}\text { Sampl } \\
\mathrm{e}\end{array}$ & Region & Center & $\begin{array}{c}\text { Ty } \\
- \\
\text { pe } \\
\end{array}$ & $\begin{array}{c}\text { Metho } \\
\text { d }\end{array}$ & $\mathrm{N}$ & $\mathrm{N}^{*}$ & $\begin{array}{c}\text { Age, } \\
\text { Ma }\end{array}$ & $\begin{array}{l}\text { Erro } \\
\text { r, Ma }\end{array}$ & & $\begin{array}{c}\text { Type } \\
\text { of } \\
\text { error }\end{array}$ & category \\
\hline SG & Strandzh & Oman- & & LA- & & & & & & $95 \%$ & confiden \\
\hline 047 & $\mathrm{a}$ & Fakya & $\mathrm{i}$ & ICPMS & 10 & 5 & 293.80 & 7.60 & $\mathrm{C}$ & conf. & $\mathrm{t}$ \\
\hline SG & Strandzh & Zheljazkov & & ID- & & & & & & & confiden \\
\hline 059 & $\mathrm{a}$ & o & $\mathrm{i}$ & TIMS & 4 & 3 & 301.26 & 0.97 & $\mathrm{C}$ & sigma & $\mathrm{t}$ \\
\hline SG & Strandzh & Monastery & & LA- & & & & & & & confiden \\
\hline 070 & $\mathrm{a}$ & Heights & $\mathrm{i}$ & ICPMS & 11 & 5 & 274.10 & 4.50 & $\mathrm{C}$ & sigma & $\mathrm{t}$ \\
\hline
\end{tabular}

Abbreviations: $v$ - volcanic; $i$ - intrusive; $N$ - number of grains analyzed from the sample with the reported method; $N^{*}$ - the number of grains, used for the calculation of the crystallization age; $C$ - concordia

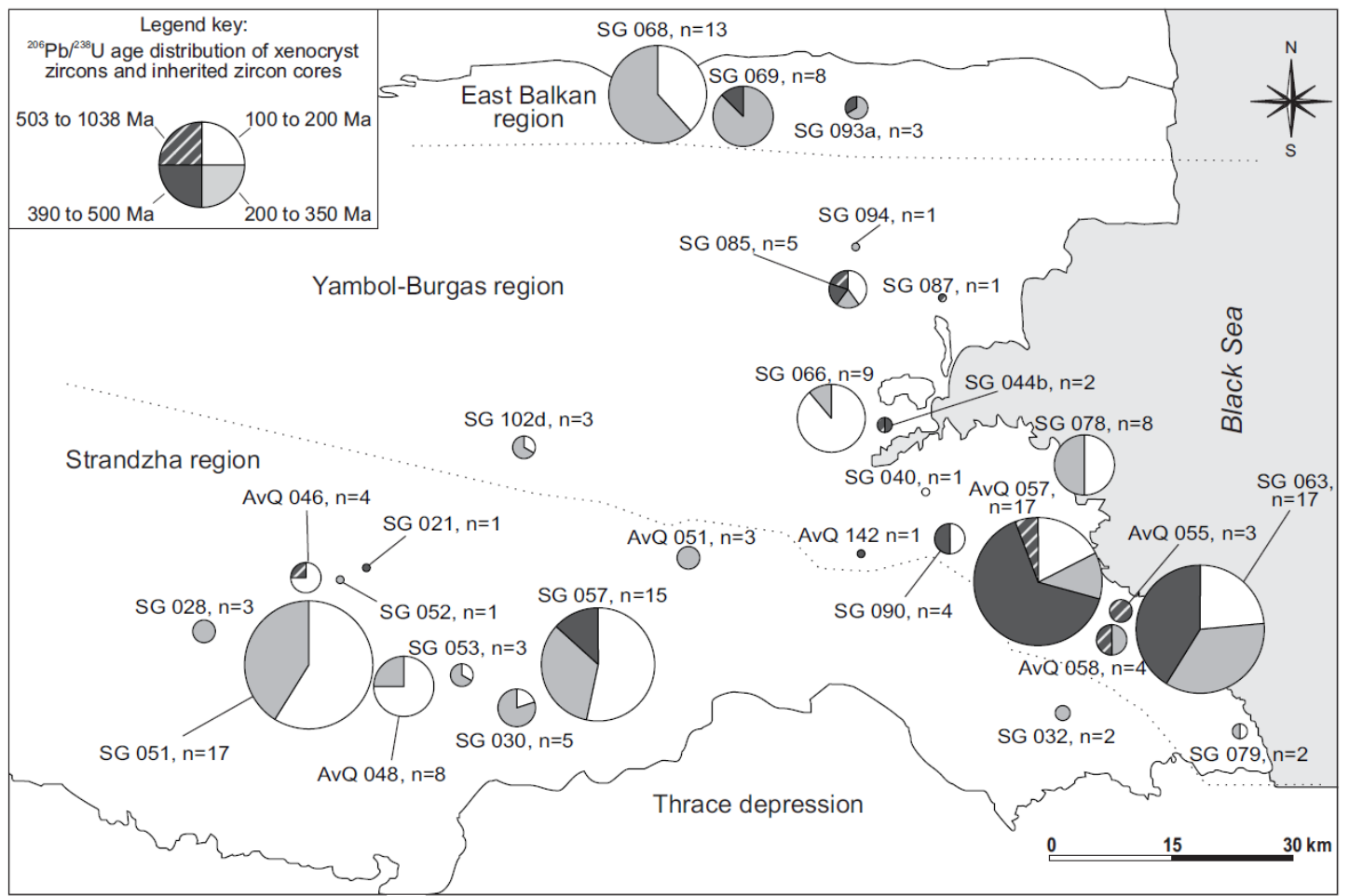

Figure 6. Sketch map showing the ${ }^{206} \mathrm{~Pb} /{ }^{238} \mathrm{U}$ age distribution of inherited zircon cores and xenocryst zircons detected in Upper Cretaceous magmatic rocks (ID-TIMS and LA-ICPMS data). Some ID-TIMS $206 \mathrm{~Pb} / 238 \mathrm{U}$ zircon ages may represent mixtures of inherited cores and younger, Late Cretaceous rims. Sample location is approximate. The size of each circle is proportional to the number of inherited cores and xenocryst zircons (n) detected in the sample.

Calculated ages from ID-TIMS analyzed inherited grains are presented in Table 3. As with the single-grain ${ }^{206} \mathrm{~Pb} /{ }^{238} \mathrm{U}$ ages, in the southernmost and northernmost regions (Strandzha and East Balkan) most inherited ages are 270-350 Ma old, whereas in the central regions the 404-450 Ma inherited ages dominate. Three significantly older ages at 1, 1.4 and $2 \mathrm{Ga}$ are recorded in inherited zircons from the Yambol-Burgas region; such older ages were not found in Upper Cretaceous igneous rocks from the East Balkan and 
Strandzha region (Fig. 5b, Table 3). An inherited core in a Variscan basement rock (sample SG 047) also has a similar concordant 2 Ga LA-ICPMS age.

In summary, the Strandzha and East Balkan regions have similar inheritance patterns with most grains clustering at $\sim 300 \mathrm{Ma}$, while in the Yambol-Burgas region the most prominent peak is at $\sim 460 \mathrm{Ma}$, with several grains showing considerably older ages.

Table 3. Calculated crystallization ages for unexposed basement rocks from Eastern Srednogorie zone, based on inherited grains entrained in Late Cretaceous igneous rocks.

\begin{tabular}{|c|c|c|c|c|c|c|c|c|c|c|}
\hline Sample & Region & Center & Type & $\mathrm{N}$ & $\mathrm{N}^{*}$ & Age, Ma & Error, Ma & Age type & MSWD & Type of error \\
\hline SG 093a & East Balkan & Zaimchevo & $\mathrm{v}$ & 3 & 1 & 271 & 0.7 & $\mathrm{C}$ & & 2 sigma \\
\hline SG 093a & East Balkan & Zaimchevo & $\mathrm{v}$ & 3 & 3 & 577 & 57.0 & UI & 0.13 & $95 \%$ conf. \\
\hline SG 068 & East Balkan & Zvezda & $\mathrm{i}$ & 17 & 4 & 109 & 6.7 & LI & 0.33 & $95 \%$ conf. \\
\hline SG 068 & East Balkan & Zvezda & $\mathrm{i}$ & 17 & 4 & 139 & 18.0 & UI & 2.20 & $95 \%$ conf. \\
\hline SG 069 & East Balkan & Zvezda & d & 3 & 1 & 281 & 0.9 & $\mathrm{C}$ & & 2 sigma \\
\hline SG 068 & East Balkan & Zvezda & $\mathrm{i}$ & 17 & 1 & 303 & 0.5 & $\mathrm{C}$ & & 2 sigma \\
\hline SG 068 & East Balkan & Zvezda & $\mathrm{i}$ & 17 & 1 & 350 & 8.8 & $\mathrm{C}$ & & $95 \%$ conf. \\
\hline SG 085 & Yambol-Burgas & Bulgarovo & $\mathrm{v}$ & 3 & 1 & 631 & 23.0 & $\mathrm{C}$ & & $95 \%$ conf. \\
\hline SG 044b & Yambol-Burgas & Vurli Brjag & $\mathrm{v}$ & 4 & 1 & 442 & 20.0 & $\mathrm{C}$ & & $95 \%$ conf. \\
\hline SG 044b & Yambol-Burgas & Vurli Brjag & $\mathrm{v}$ & 4 & 1 & 1039 & 4.2 & $\mathrm{C}$ & & 2 sigma \\
\hline AvQ 057 & Yambol-Burgas & Izgrev & $\mathrm{i}$ & 13 & 1 & 160 & 0.6 & $\mathrm{C}$ & & 2 sigma \\
\hline AvQ 057 & Yambol-Burgas & Izgrev & $\mathrm{i}$ & 13 & 1 & 280 & 0.7 & $\mathrm{C}$ & & 2 sigma \\
\hline AvQ 058 & Yambol-Burgas & Izgrev & $\mathrm{v}$ & 4 & 3 & 296 & 3.7 & LI & 0.60 & $95 \%$ conf. \\
\hline AvQ 057 & Yambol-Burgas & Izgrev & $\mathrm{i}$ & 13 & 2 & 404 & 0.9 & $\mathrm{C}$ & & 2 sigma \\
\hline AvQ 058 & Yambol-Burgas & Izgrev & $\mathrm{v}$ & 4 & 1 & 445 & 1.6 & $\mathrm{C}$ & & 2 sigma \\
\hline AvQ 057 & Yambol-Burgas & Izgrev & $\mathrm{i}$ & 13 & 1 & 462 & 1.2 & $\mathrm{C}$ & & 2 sigma \\
\hline AvQ 057 & Yambol-Burgas & Izgrev & $\mathrm{i}$ & 13 & 3 & 1353 & 30.0 & UI & 0.46 & $95 \%$ conf. \\
\hline AvQ 058 & Yambol-Burgas & Izgrev & $\mathrm{v}$ & 4 & 3 & 1948 & 3.7 & UI & 0.60 & $95 \%$ conf. \\
\hline SG 063 & Yambol-Burgas & Izgrev? & d & 5 & 3 & 450 & 26.0 & UI & 0.56 & $95 \%$ conf. \\
\hline SG 063 & Yambol-Burgas & Izgrev? & $\mathrm{d}$ & 5 & 3 & 507 & 9.2 & UI & 0.30 & $95 \%$ conf. \\
\hline AvQ 046 & Strandzha & Monastery Heights & $\mathrm{i}$ & 4 & 1 & 85 & 0.3 & $\mathrm{C}$ & & 2 sigma \\
\hline AvQ 046 & Strandzha & Monastery Heights & $\mathrm{i}$ & 4 & 1 & 92 & 0.2 & $\mathrm{C}$ & & 2 sigma \\
\hline AvQ 046 & Strandzha & Monastery Heights & $\mathrm{i}$ & 4 & 1 & 104 & 2.0 & $\mathrm{C}$ & & 2 sigma \\
\hline SG 021 & Strandzha & Monastery Heights & $\mathrm{d}$ & 4 & 3 & 541 & 33.0 & UI & 0.05 & $95 \%$ conf. \\
\hline AvQ 048 & Strandzha & Granitovo & $\mathrm{i}$ & 15 & 1 & 81 & 0.3 & $\mathrm{C}$ & & 2 sigma \\
\hline SG 051 & Strandzha & Granitovo & $\mathrm{i}$ & 6 & 4 & 268 & 37.0 & UI & 1.50 & $95 \%$ conf. \\
\hline AvQ 048 & Strandzha & Granitovo & $\mathrm{i}$ & 15 & 6 & 281 & 64.0 & UI & 0.65 & $95 \%$ conf. \\
\hline AvQ 051 & Strandzha & Oman-Fakya & $\mathrm{i}$ & 6 & 5 & 329 & 27.0 & UI & 6.10 & $95 \%$ conf. \\
\hline SG 057 & Strandzha & Sharkovo & $\mathrm{i}$ & 5 & 3 & 112 & 5.2 & LI & 2.00 & $95 \%$ conf. \\
\hline SG 057 & Strandzha & Sharkovo & $\mathrm{i}$ & 5 & 1 & 138 & 0.3 & $\mathrm{C}$ & & 2 sigma \\
\hline SG 057 & Strandzha & Sharkovo & $\mathrm{i}$ & 5 & 1 & 291 & 0.6 & $\mathrm{C}$ & & 2 sigma \\
\hline SG 057 & Strandzha & Sharkovo & $\mathrm{i}$ & 5 & 4 & 296 & 14.0 & UI & 0.28 & $95 \%$ conf. \\
\hline SG 057 & Strandzha & Sharkovo & $\mathrm{i}$ & 5 & 3 & 442 & 6.1 & UI & 2.00 & $95 \%$ conf. \\
\hline SG 030 & Strandzha & Voden & $\mathrm{v}$ & 5 & 5 & 162 & 8.1 & LI & 1.40 & $95 \%$ conf. \\
\hline SG 030 & Strandzha & Voden & $\mathrm{v}$ & 5 & 5 & 285 & 35.0 & LI & 0.40 & $95 \%$ conf. \\
\hline SG 030 & Strandzha & Voden & $\mathrm{v}$ & 5 & 5 & 397 & 24.0 & UI & 1.40 & $95 \%$ conf. \\
\hline SG 032 & Strandzha & Gramatikovo? & $\mathrm{d}$ & 3 & 3 & 470 & 15.0 & UI & 1.90 & $95 \%$ conf. \\
\hline
\end{tabular}

Abbreviations: $v$ - volcanic; $i$ - intrusive; $N$ - number of grains analyzed from the sample with the reported method; $N^{*}$ - the number of grains, used for the calculation of the crystallization age; C - concordia; LI - lower intercept; UI - upper intercept 


\section{Discussion}

\subsection{Across- arc age zonation of the Late Cretaceous magmatism}

Stratigraphic relations with fossil-bearing Upper Cretaceous sediments provide age constraints for the extrusive magmatism in the northernmost East Balkan region (Kunchev, 1966; summary in Dabovski et al., 2009b). These authors assign a Late Cenomanian-Early Turonian age of the magmatism based on abundant ammonite and foraminifera assemblages preserved in marly-calcareous and in flysch-like sediments intercalated with the volcanic products in the East Balkan. These stages correspond to 95-90 Ma based on numerical ages in Ogg et al. (2008). We were unable to obtain highconfidence ages for East Balkan magmatism, but the indications for 290 Ma old ages (Fig. $5 a)$ are consistent with the well constrained stratigraphic age of the samples.

Further south, volcanism and sedimentation in the central Yambol-Burgas region are considered Coniacian-Santonian-Campanian (90-70 Ma) based on rare fossils in the successions (Georgiev et al., 2001; Dabovski et al., 2009b), but our data suggest a much narrower time interval between 81 and $78 \mathrm{Ma}$ (Fig. 4). The Izgrev, Vurli Brjag and Rossen plutons, intruded in the volcano-sedimentary Late Cretaceous successions, yield precise and high-confidence TIMS zircon ages at ca. 80-79 Ma (Figs. 3, 4). These ages constrain the minimum age of the intruded volcano-sedimentary sequence. Volcanic rocks have similar, but less precise U-Pb zircon ages (Fig. 4). The geochemistry and $\mathrm{Pb}$ and Sr isotopic composition of intrusive and volcanic rocks from a given center (e.g. Izgrev or Rossen, data from Georgiev et al., 2009) suggests that they evolved from chemically similar magmas and are therefore essentially coeval. In this region, zircons concordant within the small uncertainties of the ID-TIMS data form a single population with a clear peak at 8279 Ma (Fig. 5a), providing additional evidence that volcanism in the Yambol-Burgas region is largely coeval with the dated intrusions. Less precise LA-ICPMS ages indicate that some of the magmatism may be younger than $78 \mathrm{Ma}$ (Figs. 4, 5a), consistent with scarce field observations for post-intrusive emplacement of volcanic rocks (Ivanov, 1979).

High-confidence crystallization ages in the southernmost Strandzha region define two distinct Late Cretaceous magmatic events at $\sim 87-85$ Ma and $\sim$ (Fig. 4). Concordant IDTIMS inherited zircons at $\sim 86$ and $\sim 90 \mathrm{Ma}$ (Fig. 5a) suggest incorporation of older Upper Cretaceous rocks by the 81-78 Ma Upper Cretaceous magmas.

\subsection{Comparison with Central Srednogorie zone}

Detailed geochronology in the adjacent segment of the ABTS belt, the Central Srednogorie, reveals a $14 \mathrm{Ma}$ age progression from north $(\sim 92 \mathrm{Ma})$ to south $(\sim 78 \mathrm{Ma})$, coupled with a southward increase of mantle input recorded by $\mathrm{Nd}$, $\mathrm{Sr}$ and $\mathrm{Hf}$ isotopes (von Quadt et al., 2005). This is best explained by hinge retreat (roll back) that led to overall crustal thinning and asthenospheric incursion into an extending arc to back-arc environment (von Quadt et al., 2005). Comparison of crystallization ages of rocks from Eastern Srednogorie zone with the published age data from the Central Srednogorie zone (Fig. 7) shows important similarities.

Magmatism in the East Balkan region is initiated at 94-90 Ma, similar to zircon ages from Elatsite and Chelopech in northernmost Central Srednogorie zone ( $92 \mathrm{Ma}$, von Quadt et al., 2005). Also geochemically, the high $\mathrm{K}$ and calc-alkaline, shallow, and mostly intermediate subvolcanic bodies and associated volcanics from the East Balkan are similar to those from the northern part of Central Srednogorie zone (Elatsite, Chelopech, Assarel).

Further south, the 87-85 Ma intrusions and dikes ages in the Strandzha region (Fig. 4) are similar to the $86 \mathrm{Ma}$ age of Elshitsa intrusion in the central part of Central Srednogorie zone. Most intrusions in the Strandzha region crystallized between 82 to $78 \mathrm{Ma}$; such ages are reported from the southern part of Central and Western Srednogorie zones, for Vurshilo, Vitosha and Capitan Dimitrievo intrusions (Peytcheva et al., 2008). In terms of 


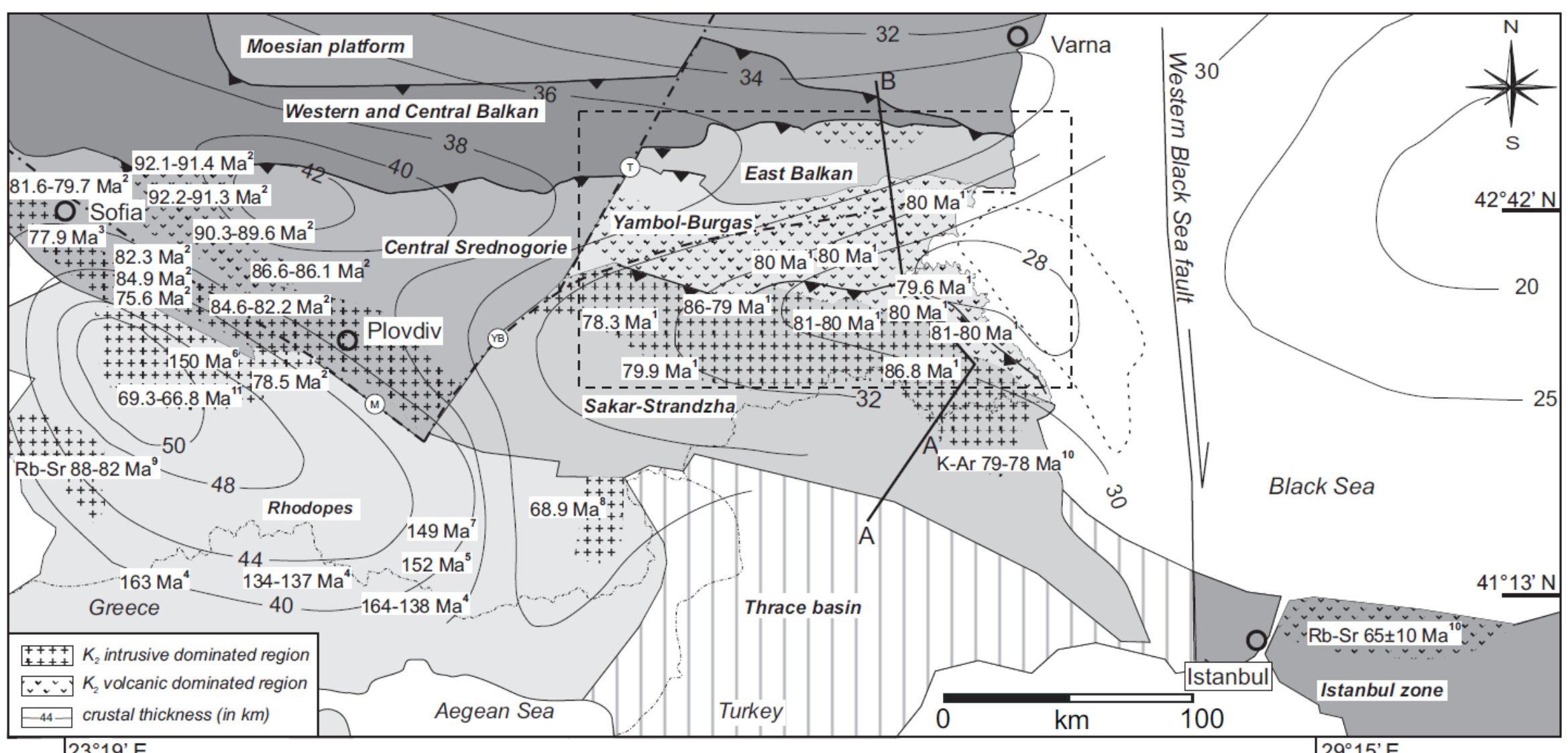

Figure 7. Simplified tectonic map of Eastern Srednogorie zone and surrounding areas, showing crustal thickness (in km) and approximate sample location of published Late-Jurassic to Late Cretaceous magmatic ages discussed in the main text. Superscript numbers are references for radiometric ages as follows: 1 - U-Pb zircon ID-TIMS and LA-ICPMS ages, this study; 2 - U-Pb zircon ID-TIMS (von Quadt et al., 2005); 3 - U-Pb zircon ID-TIMS for Plana pluton (Lora Bidzhova, personal communication); 4 - U-Pb zircon SHRIMP and Pb-Pb evaporation (Turpaud and Reischmann, 2009); 5,6 - U-Pb zircon ID-TIMS (Ovtcharova et al., 2004, Peytcheva et al., 2004 ); 7 - U-Pb zircon ID-TIMS (Cherneva et al., 2006); 8 - U-Pb zircon ID-TIMS (Marchev et al., 2006); 9 - Rb-Sr whole-rock (Zagorčev and Moorbath, 1983); 10 - K-Ar on Bt and Hb (Moore et al., 1980); 11 - Rb-Sr whole-rock (Öztunali and Satir, 1975). Crustal thickness lines from Yosifov and Pchelarov (1977); Black Sea crustal thickness from Dachev (1988). Stippled field in the Black Sea is the area of most intense magnetic anomalies after Yosifov et al. (1986). 
geochemistry and emplacement depth, the deeply eroded middle (?) - crustal gabbroic and granodioritic intrusions with predominantly calc-alkaline affinity in the Strandzha region are similar to the deeply eroded Vurshilo and Capitan Dimitrievo intrusions in the southern Central Srednogorie zone.

Based on the overall similarities in crystallization age, geochemistry and emplacement depth of the magmatism, the East Balkan and Strandzha regions of Eastern Srednogorie zone may be considered eastwards equivalents of the northern and southern parts of Central Srednogorie zone, respectively. We conclude that the large-scale process of slab retreat that operated in Central Srednogorie zone during the Late Cretaceous was probably active also in the Eastern Srednogorie zone, with ages migrating from ca. $90 \mathrm{Ma}$ in the East Balkan to 87-85 Ma and 82-78 Ma in the Strandzha region.

The voluminous mafic to intermediate alkaline magmatism in the central Yambol-Burgas region has no equivalent in Central Srednogorie. Characteristically, the 81-78 Ma old magmatism in the Yambol-Burgas region lacks evidence for the 90-86 Ma events as seen in the East Balkan and Strandzha regions, respectively. The distribution of pre-Cretaceous inherited zircons in this region also clearly differ from those in the East Balkan and Strandzha regions (Figs. 5a, 5b and 6), which is an indication for a possibly different origin of the Yambol-Burgas region. This, combined with the markedly elevated alkalinity of the Yambol-Burgas rocks intermingled with deep marine sediments, are all consistent with the formation of a Late Cretaceous intra-arc rift that separated a previously uniform arc (East Balkan and Strandzha regions) in two parts.

The peak of the magmatism in the Strandzha region overlaps the range of crystallization ages in the Yambol-Burgas region (81-78 Ma). The similar age, but different chemistry and emplacement depth require explanation. One possibility is that rollback caused intraarc rifting and melting of upper mantle or lower crustal rocks; these newly formed magmas were granted a facilitated access through the thinned crust in the extensional regime of the Yambol-Burgas region. Alternatively, extension in the neighboring Black Sea might have caused rifting and related slab roll back. Regardless of the cause for rifting and slab roll back, our age data show that the thicker crust of the Strandzha region was penetrated by melts simultaneously with the rifting phase in the neighboring YambolBurgas region. The abundance of intrusive rocks exposed in the Strandzha region is a result of late exhumation.

The lack of clear along-strike age zonation in Eastern Srednogorie zone does not support the model for east-to-west slab break-off (Neubauer, 2002), which predicts progressively younger magmatic ages along the strike of the ABTS belt in an east-west direction. The overlapping age range of the magmatism in the Central and Eastern Srednogorie zones are also inconsistent with the slab break-off model.

\subsection{Eastward continuation and relation to the Black Sea}

The Srednogorie zone with its deep marine sedimentary succession (Aiello et al., 1977) is considered as a westerly continuation of the Black Sea basin (Hsü et al., 1977). However, the major subsidence and deepening of the Eastern Srednogorie basin is postCenomanian, about 10-30 Ma younger than the mid-Cretaceous opening of the Black sea. A westward propagating rifting was proposed to explain the later opening of the Srednogorie basin (Görür, 1988).

In terms of volume and emplacement mechanisms, the abundant mafic magmatism in the Yambol- Burgas region could represent part of the Black Sea oceanic crust, but its subduction influenced trace element composition clearly differs from typical mid-ocean ridge magmatism (Georgiev et al., 2009). Moreover, geophysical data indicate that large Bouguer anomalies (Dachev, 1988) and positive magnetic anomalies that characterize the oxidized magmatism in the Eastern Srednogorie zone do not continue uninterrupted within the Black Sea (Dachev, 1988; Roussanov and Pchelarov, 1998). They form a zone that bends offshore at almost 90 degrees and runs in a south-southeast direction almost parallel to the present shore (Fig. 7). These features are not consistent with the idea that 
the Srednogorie zone magmatism (including the Yambol-Burgas region) represents Black Sea oceanic crust.

The offshore curvature of the Yambol-Burgas region coincides with the observed orientation of the dome-like uplifts in the Strandzha region, which have an east-west orientation in its western part and a NW-SE orientation in the eastern part. This change could have resulted from syn- to post-magmatic dextral strike-slip movements along the Western Black sea fault (Fig. 7), which is considered central for the opening of the Black Sea basin (Okay et al., 1994; Banks and Robinson, 1997; Nikishin et al., 2001; Nikishin et al., 2003). The Western Black sea fault also separates the Srednogorie zone from the Western Pontides Mountains in the Istanbul zone, which host abundant Upper Cretaceous arc magmatism. If movements along this fault caused the separation of a formerly continuous Upper Cretaceous arc comprising the Srednogorie zone and the Western Pontides, our age results imply major movements in the order of 100-150 km along this fault occurred later than the Santonian. The south- southeast curvature of the Srednogorie zone can be explained by the tail effect of southwards syn- to post- magmatic movements of the western Black Sea plate along the Western Black Sea fault, distorting and displacing the easternmost Srednogorie zone southwards. Additionally, paleomagnetic data indicate that the Srednogorie zone drifted 200 to $400 \mathrm{~km}$ northwards since the Late Cretaceous (Nozharov et al., 1984) as part of stable Europe. These northward movements may have also contributed to the southward tilting of easternmost Srednogorie.

\subsection{Age of basement rocks and inherited zircons}

The Late Carboniferous to Early Permian (274-301 Ma) age of intrusive rocks from the Eastern Srednogorie basement (Table 2) confirm that the studied region was actively involved in the Variscan collisional orogeny, which accreted fragments of Gondwanaland (Moesian, Balkan and Thracian terranes) to each other and to Laurasia (Yanev, 2000). Similar to older $\mathrm{U}-\mathrm{Pb}$ zircon ages are reported for Variscan intrusions from the Central Srednogorie (Peytcheva and von Quadt, 2004; Carrigan et al., 2005; von Quadt et al., 2005), and for metagranites from the neighboring Eastern Rhodopes (Peytcheva and von Quadt, 1995). This age similarity may indicate that the Rhodope Massif, Central Srednogorie and Eastern Srednogorie zones constituted a single terrain during the Permian.

Inherited grains provide additional age constraints for the underlying basement (Fig. 5b). Permian-Carboniferous inherited zircon ages of $\sim 300 \mathrm{Ma}$ are characteristic for the East Balkan and Strandzha regions and probably originate from assimilation of the presently exposed Permian/Carboniferous basements rocks in Strandzha and East Balkan. In contrast, $\sim 460$ Ma old inherited zircon grains are found mostly in the Yambol-Burgas region (Fig. 5b), where the pre-Cretaceous basement is not exposed or reached in drill cores in the Yambol-Burgas region. Similar Ordovician ages have been found in Upper Cretaceous intrusions and several Variscan granitoids from the Central Srednogorie zone (Peytcheva and von Quadt, 2004; Carrigan et al., 2005; Peytcheva et al., 2009) and in the Rhodopean metamorphic basement (Bonev et al., 2010). The different inheritance pattern in the Yambol-Burgas region suggests that either the basement here is different, or that the Late Cretaceous magma chambers were situated at a different depth, compared to those in Strandzha and East Balkan. The latter hypothesis is consistent with thermobarometric estimates for olivine and clinopyroxenes crystallization in deep magma chambers, close to the Moho discontinuity (Georgiev et al., 2009). Therefore, the Ordovician inherited ages are a possible indication that the lower crustal rocks in the region have an Ordovician age.

\subsection{Tectono-magmatic evolution of a rifted arc}

This section integrates the regional geological, geochemical and age information into a model of the geodynamic evolution of the Eastern Srednogorie zone (Fig. 8). 


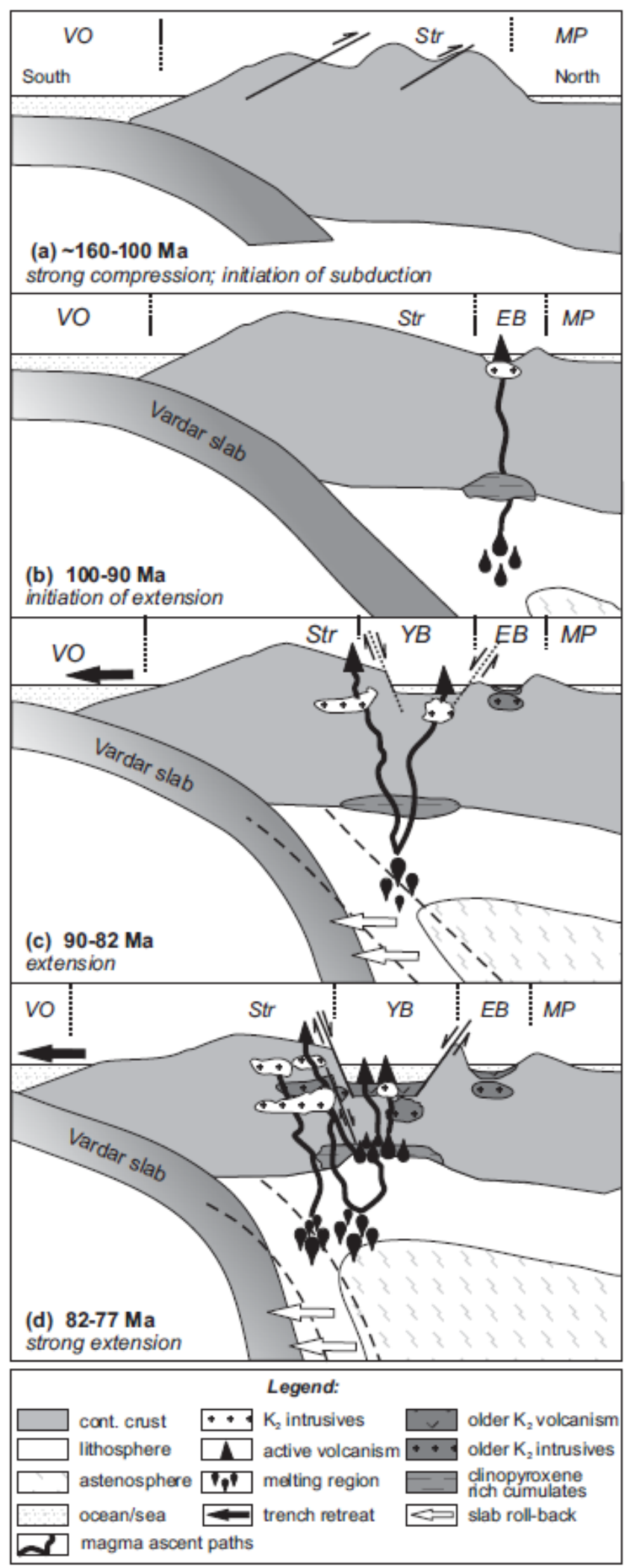

Figure 8. Schematic cartoon, illustrating in a series of diagrams (a-d) our model for the Late Cretaceous geodynamic evolution of Eastern Srednogorie zone. VO - Vardar Ocean; Str - Strandzha region; YB - YambolBurgas region; EB - Eastern Balkan region; MP - Moesian platform; Thr - Thrace depression. Note the absence of an absolute scale, due to the contrasting thickness of the upper crust, oceanic and sea depth on one side, and the subducting slab, lithosphere and asthenosphere on the other. The clinopyroxenite cumulates are drawn as products of the magmatism in (b); however, these cumulates may also have formed during an earlier stage. See text for detailed explanation. 
The Late Jurassic-Early Cretaceous geodynamic evolution was characterized by successive phases of intense compression, northward thrusting, folding and uplift in the Strandzha region (Banks, 1997; Sunal et al., 2011). Ar/Ar mica ages indicate a 140 Ma age of the deformation (Neubauer et al., 2010), whereas K-Ar ages of illites/muscovites from phyllites and diabases from the Bulgarian portion of Strandzha Mountains indicate a Jurassic (160-170 Ma) age of the low-grade greenschist facies metamorphism (Lilov et al., 2004). Rb-Sr muscovite and biotite ages from the southern part of Strandzha mountains reveal that peak metamorphic conditions occurred at around $160 \mathrm{Ma}$ (Sunal et al., 2011), supporting earlier biotite whole-rock Rb-Sr Late Jurassic (155 Ma) age of the regional metamorphism (Okay et al., 2001). This compression was most likely related to the subduction/collision system in the southerly lying Rhodope Massif (e.g. Sunal et al., 2011) and resulted in the closure of the Nish-Troyan trough to the northwest of the studied area and folding of its flysch sediments at the end of the Late Jurassic (Nachev and Nachev, 2003). At this time the area of Eastern Srednogorie zone was not magmatically active and was above the sea level (Fig. 8a). The Moesian platform to the north was a shallow epicontinental sea with continuous sedimentation.

Sedimentation in Eastern Srednogorie zone commenced at the end of the Lower Cretaceous and the Cenomanian with deposition of alluvial, lake and swamp sediments, followed by initiation of marine transgression during the Cenomanian - Turonian (Nachev and Dimitrova, 1995b) when marine deposits were formed in a shallow epicontinental sea (Fig. 8b). Magmatic activity was limited to volumetrically minor shallow intrusives, dikes, and associated andesitic lava flows in the present day East Balkan. Their age is considered Late Cenomanian-Early Turonian based on characteristic fauna in associated marls and flysch sediments (Kunchev, 1966; Dabovski et al., 2009b).

The geodynamic setting changed significantly during the Coniacian with the onset of an intra-arc basin formation. The subducting slab migrated southwards, resulting in the formation of $86 \mathrm{Ma}$ old intrusions and probably volcanics (which were later eroded) in the Strandzha region (Fig. 8c). In our model the slab retreat was a continuous process, similar to the slab retreat in the Central Srednogorie zone (von Quadt et al., 2005). Some 93-87 Ma magmatic products may be situated between Strandzha and East Balkan, now covered by sediments and volcanic products deposited during the intra-arc rift phase.

The 82-77 Ma time period was the most intense phase of extension and crustal thinning in the Yambol-Burgas and North-Burgas regions (Fig. 8d). A thick volcano-sedimentary succession was deposited in a deep marine basin (Nachev and Nachev, 2003). Decompression and crustal thinning combined with increased corner flow in the mantle wedge and associated rise in the temperature led to large-scale melting of lowercrustal/upper mantle clinopyroxene-rich and amphibole-bearing cumulates (Georgiev et al., 2009). The crystallization age for the cumulates is unclear: they could have formed during the previous stage of the Late Cretaceous magmatism (e.g. Fig. 8c), or could be significantly older. Melts from such cumulates mixed with mantle-wedge melts produced the mafic and intermediate alkaline magmatism in the Yambol-Burgas region, including the primitive nepheline-normative ankaramites (Georgiev et al., 2009; Marchev et al., 2009). During this period, mantle wedge melts penetrated the thicker crust in the Strandzha region and crystallized as lower-, middle- or upper crustal intrusions (Fig. 8d). Melt access to the crust might have been facilitated by the possible presence of normal faults, parallel to the main rift fault (Fig. 8d). The $\sim 80 \mathrm{Ma}$ old igneous rocks from the Yambol-Burgas and Strandzha regions have notably different geochemistry (e.g. Stanisheva-Vassileva, 1980; Georgiev et al., 2009). One possible explanation for these differences may be the lack of clinopyroxene-rich and amphibole containing cumulates in the lower crust of the Strandzha region. However, a more probable explanation is that the thicker crust in the Strandzha region prevented large-scale decompressional melting of clinopyroxenite cumulates. Rather, mantle-wedge-derived magmas intruded the thicker crust of Strandzha to form tholeiitic, calc-alkaline and partly high-K intrusions. The relatively similar present-day crustal thickness between the Yambol-Burgas and 
Strandzha regions (Fig. 8) results from post-magmatic shortening and deformation. In the Late Cretaceous the crust in the Strandzha region was probably much thicker than the crust in the Yambol-Burgas region.

Late Cretaceous magmas in the Yambol-Burgas region erupted on the seafloor or crystallized as shallow intrusives, whereas concomitant intrusions in the Strandzha region crystallized at pressures between 0.7 and $0.2 \mathrm{GPa}$ (Dabovski et al., 2009a). Stronger Cenozoic erosion in the elevated Strandzha region compared to the YambolBurgas region may have removed Cretaceous volcanic products. The extensional Late Cretaceous environment in the intermediate Yambol-Burgas region was favorable for the formation of polymetallic vein deposits; submarine volcanogenic-hosted massive sulphide deposits may also be present. In contrast, mostly skarn deposits developed around the deeper intrusions in the Strandzha region.

During the same stage (82-77 Ma), the area of the East Balkan region developed as a separate, non-magmatic deep back-arc basin (Fig. 8d). The lack of volcanic material in the post-Turonian deep-water sediments of East Balkan and their abundance in contemporaneous Yambol-Burgas sediments suggest that both basins were physically separated during the Coniacian-Maastrictian. Nachev and Nachev (2003) proposed the existence of a second elevated arc (in addition to the frontal Rhodope arc) between the Yambol-Burgas and the East Balkan basins. In our model the elevated northern rift shoulder of the Yambol-Burgas intra-arc rift acted as a paleo-relief barrier that prevented the deposition of explosive volcanic material in the deep East Balkan basin.

Sedimentation in the Yambol-Burgas intra-arc rift continued between 77 and $73 \mathrm{Ma}$ (not shown on Fig. 8), probably accompanied by volumetrically small volcanic activity. Towards the end of this period the basin was terminated by uplift, intense thrusting and folding of the sedimentary and volcanic successions, with the total shortening estimated by a factor of three to the original width (Nachev and Nachev, 2003). There is no evidence for magmatic activity in the Strandzha or East Balkan regions at that time. The slab retreat continued further to the south; some younger magmatic products in the southern Strandzha area may be present beneath the younger sediments of the Thrace depression (Fig. 7). At the beginning of Maastrichtian ( $73 \mathrm{Ma})$, shallow water limestones were deposited in the Yambol-Burgas region above the folded Late Cretaceous successions. Sedimentation in the East Balkan continued in a deeper-water environment and the basin was terminated before the Late Paleocene (Nachev and Nachev, 2003). To the south, evidence for further slab retreat and subduction magmatism comes from the Eastern Rhodope and Rila Mountain area where few intrusions have 70-65 Ma ages (Fig. 7). A possible equivalent of this magmatism is a granodiorite from the Istanbul zone in Turkey, which has a Rb-Sr age of $65 \pm 10$ Ma (Öztunali and Satir, 1975).

The present day structure of the Eastern Srednogorie zone resulted from the multiple northward thrusting during the Early Cretaceous - Paleogene time, which superimposed Strandzha on top of the Yambol-Burgas region, and also parts of North-Burgas region on top of East Balkan (Fig. 3). The East Balkan region itself is thrusted on top of the stable Moesian platform. The surface features are dominated by northward thrusting, which is detected also in the deeper basement. Geophysical data indicate that the rift geometry is preserved only in the deep basement of the Yambol-Burgas, and partly East Balkan zone (Georgiev et al., 2001).

\section{Conclusions}

$\mathrm{U}-\mathrm{Pb}$ zircon dating by ID-TIMS and LA-ICPMS methods combined with a synthesis of the regional geology shows that magmatism in the Eastern Srednogorie zone commenced at ca. 90 Ma with volcanism in the northernmost East Balkan region. With time, the magmatic activity migrated southwards, evidenced by several 86 Ma old plutonic bodies that intruded the basement of the present-day Strandzha region. Magmatic activity in the Eastern Srednogorie zone peaked between 81 and $78 \mathrm{Ma}$, when numerous intrusions crystallized in the Strandzha and Yambol-Burgas regions and abundant volcanics were 
formed in the Yambol-Burgas region. The crystallization age of basement granites and gabbros from the Strandzha region is determined as Permian to Carboniferous. Upper Cretaceous rocks from all regions contain abundant inherited zircons. Their age distribution pattern is similar in the Strandzha and East Balkan regions where ca. $300 \mathrm{Ma}$ inherited zircons from the local basement prevail. In contrast, most of the inherited zircons in the Yambol-Burgas region point to an Ordovician age of ca. $450 \mathrm{Ma}$ and few grains have much older ages of 1 to $2 \mathrm{Ga}$.

Integrating new geochronology results with existing geological and geochemical data, we propose a model for the temporal evolution of the magmatism in the Eastern Srednogorie zone. Our model involves a southward retreating slab and related arc magmatism similar to the one in the Central Srednogorie zone, with older calc-alkaline to high-K shallow intrusions and volcanics in the north (East Balkan) and younger large mid-crustal tholeiitic, calc-alkaline and high-K intrusions in the south (Strandzha). The southward migration of the magmatism lasted from $\sim 90 \mathrm{Ma}$ (East Balkan) to $\sim 78 \mathrm{Ma}$ (the youngest intrusions in Strandzha). Subduction roll-back, combined with processes of widening of the Black Sea basin and major dextral strike-slip movements along the western Black Sea fault led to the formation of an intra-arc rift basin (Yambol-Burgas) which separated the formerly adjacent East Balkan and Strandzha regions. The main phase of the intra-arc rift alkaline-rich magmatism was from 81 to $78 \mathrm{Ma}$. Subsequent latest Cretaceous and Cenozoic compression events led to crustal shortening, deformation and northward thrusting, forming the present-day structure of Eastern Srednogorie zone.

\section{Acknowledgements}

We thank Ramon Aubert and Elena Stancheva for their help with zircon separation and Kalin Kouzmanov for his generous help with the CL and BSE imaging. We are grateful to Zhivko Ivanov for his advice and guidance during the first field work season in Strandzha Mountains, to Stoimen Bilyarsky for his help in the field and for testing the limits of his limitless Wartburg, and to Dimitar Paskalev for his assistance with field work in the East Balkan. We thank Franz Neubauer and an anonymous reviewer for their constructive reviews, and Nelson Eby for editorial handling. This study represents part of SG's PhD thesis at ETH Zurich supported by the Swiss National Science Foundation Projects No. 200020-100735, 200020-107955 and 200020-116693.

\section{References:}

Aiello, E., Bartolini, C., Boccaletti, M., Gočev, P., Karagjuleva, J., Kostadinov, V., Manetti, P., 1977. Sedimentary features of Srednogorie zone (Bulgaria) Upper Cretaceous intra-arc basin. Sedimentary Geology 19, 39-68.

Antonijevic, I., Grubic, A., Djordjevic, M., 1974. The Upper Cretaceous paleorift in Eastern Serbia. In: Karamata, S. (ed.) Metallogeny and Concepts of the Geotectonic development of Yugoslavia, 315-339.

Banks, C. J., 1997., Basins and thrust belts of the Balkan coast of the Black Sea. In: A.G.Robinson (ed.) Regional and petroleum geology of the Black Sea and surrounding region, American Association of Petroleum Geologists Memoir 68, pp. 115-128, Tulsa, OK. Banks, C. J., Robinson, A., 1997. Mesozoic strike-slip back-arc basins of the Western Black Sea region. In: A.G.Robinson (ed.) Regional and petroleum geology of the Black Sea and surrounding region, American Association of Petroleum Geologists Memoir 68, pp. 53-62, Tulsa, OK.

Berza, T., Constantinescu, E., Vlad, S. N., 1998. Upper Cretaceous magmatic series and associated mineralisation in the Carpathian-Balkan orogen. Resource Geology 48, 291306.

Boccaletti, M., Manetti, P., Peccerillo.A., 1974. Hypothesis on plate tectonic evolution of Carpatho-Balkan arcs. Earth and Planetary Science Letters 23, 193-198. 
Bončev, E., 1971. Lineamenttektonik und Schollengliederung der Erdkruste im ostlichen Teil der Balkanhalbinsel. Annuaire de l'Université de Sofia, Faculté de Géologie et Géographie 63, 287-303.

Bonev N., Marchev, P., Ovtcharova M., Moritz, R., Ulianov, A., 2010. U-Pb LA-ICP/MS zircon geochronology of metamorphic basement and Oligocene volcanic rocks from the SE Rhodopes: inferences for the geological history of the Eastern Rhodope crystalline basement. Geosciences 2010, Sofia. 115-116.

Burg, J.P., 2011. Rhodope: from Mesozoic convergence to Cenozoic extension.

Review of petro-structural data in the geochronological frame. Journal of

Virtual Explorer, 39 (paper 1), 44pp.

Carrigan, C. W., Mukasa, S. B., Haydoutov, I., Kolcheva, K., 2005. Age of Variscan magmatism from the Balkan sector of the orogen, central Bulgaria. Lithos 82, 125-147.

Chang, Z. S., Vervoort, J. D., McClelland, W. C., Knaack, C., 2006. U-Pb dating of zircon by LA-ICP-MS. Geochemistry Geophysics Geosystems, Q05009, doi:10.1029/2005GC001100 Chatalov, G.A., 1990. Geology of the Strandzha Zone in Bulgaria. Geologica Balcanica, Series Operum Singularum 4, Publishing House Bulgarian Academy of Sciences, Sofia, 272 pp (in Bulgarian).

Cherneva, Z., Ovtcharova, M., Dimov, D., von Quadt, A., 2006. "Baby granites" in migmatites from Chepinska river valley, Western Rhodope - geochemistry and U-Pb isotope dating of monazite and zircon. Geosciences 2006, Sofia, 205-208.

Cheshitev, G., Kanchev, I. (eds.), 1989. Geological Map of P. R. Bulgaria, 1:500 000. Sofia, Bulgaria: Supreme Technical Council

Ciobanu, C. L., Cook, N. J., Stein, H., 2002. Regional setting and geochronology of the Late Cretaceous Banatitic Magmatic and Metallogenetic Belt. Mineralium Deposita 37, 541567.

Dabovski, C., Harkovska, A., Kamenov, B., Mavroudchiev, B., Stanisheva-Vassileva, G. and Yanev, Y., 1991. A geodynamic model of the Alpine magmatism in Bulgaria. Geologica Balcanica 21 (4), 3-15.

Dabovski, C., Boyanov, I., Khrischev, K., Nikolov, T., Sapounov, I., Yanev, Y., Zagorčev, I., 2002. Structure and Alpine evolution of Bulgaria. Geologica Balcanica 32, 9-15.

Dabovski, C., Kamenov, B., Vassilev, E., 2009a. Upper Cretaceous Magmatism. In: Zagorchev, I., Dabovski, C., Nikolov, T. (eds.) Geology of Bulgaria. Volume II. Mesozoic Geology. Sofia: Academic Publishing House "Prof. Marin Drinov", 423-553 (in Bulgarian). Dabovski, C., Sinyovski, D., Vassilev, E., Dimitrova, E., 2009b. Upper Cretaceous Stratigraphy. In: Zagorchev, I., Dabovski, C., Nikolov, T. (eds.) Geology of Bulgaria, Volume II. Mesozoic Geology. Sofia: Academic Publishing House "Prof. Marin Drinov", 308-422 (in Bulgarian).

Dachev, H., 1988. Structure of the Earth's Crust in Bulgaria. Sofia: Technika (in Bulgarian). Dewey, J., Pitman, W., Ryan, W., Bonnin, J., 1973. Plate tectonics and the evolution of the Alpine system. Geological Society of America Bulletin 84, 3137-3180.

Georgiev, G., Dabovski, C., Stanisheva-Vassileva, G., 2001. East Srednogorie-Balkan rift zone. In: P.A.Ziegler, Cavazza, W., Robertson, A. H. F., Crasquin-Soleau, S. (eds.) PeriTethys Memoir 6: Peri-Tethyan Rift/Wrench Basins and Passive Margins. Paris. Memoires du Museum National d'Histoire Naturelle, 259-293.

Georgiev, S. V., Von Quadt, A., Peytcheva, I., Marchev, P., Heinrich, C. A., 2006. Eastern Srednogorie - new geochemical data for lateral zonation of magmatism. In: Geosciences 2006. Bulgarian Geological Society, Sofia, 197-200.

Georgiev, S., 2008. Sources and evolution of Late Cretaceous magmatism in Eastern Srednogorie, Bulgaria: constraints from petrology, isotope geochemistry and geochronology: PhD thesis, ETH Zurich, 270 pp.

Georgiev, S., Marchev, P., Heinrich, C., Von Quadt, A., Peytcheva, I., Manetti, P., 2009. Origin of Nepheline-Normative High-K Ankaramites and the Evolution of Eastern Srednogorie Arc in Southeastern Europe. Journal of Petrology 50, 1899-1933. 
Gerdjikov, I., 2005. Alpine metamorphism and granitoid magmatism in the Strandja Zone: new data from the Sakar unit, SE Bulgaria. Turkish Journal of Earth Sciences 14, 167-183. Görür, N., 1988. Timing of opening of the Black-Sea basin. Tectonophysics 147, 247-262. Günther, D., Audetat, A., Frischknecht, R., Heinrich, C. A., 1998. Quantitative analysis of major, minor and trace elements in fluid inclusions using laser ablation inductively coupled plasma mass spectrometry. Journal of Analytical Atomic Spectrometry 13, 263270.

Heinrich, C. A., Neubauer, F., 2002. Cu-Au-Pb-Zn-Ag metallogeny of the Alpine-BalkanCarpathian- Dinaride geodynamic province. Mineralium Deposita 37, 533-540.

Heinrich, C. A., Pettke, T., Halter, W. E., Aigner-Torres, M., Audetat, A., Günther, D., Hattendorf, B., Bleiner, D., Guillong, M., Horn, I., 2003. Quantitative multi-element analysis of minerals, fluid and melt inclusions by laser-ablation inductively-coupled-plasma massspectrometry. Geochimica et Cosmochimica Acta 67, 3473-3497.

Hsü, K., Nachev, I., Vuchev, V., 1977. Geologic evolution of Bulgaria in the light of plate tectonics. Tectonophysics 40, 245-256.

Ivanov, R., 1979. To the tectonogeochemical analysis of the Upper Cretaceous magmatism in the East Srednogorie. Review of the Bulgarian Geological Society 40, 47-61 (in Bulgarian, with English abstract).

Ivanov, Z. (in press). Geology of Bulgaria (in Bulgarian).

Janković, S., 1997. The Carpatho-Balkanides and adjacent area: a sector of the Tethyan Eurasian metallogenic belt. Mineralium Deposita 32, 426-433.

Kamenov, B., Nedialkov, R., Yanev, Y., Stoykov, S., 2003. Petrology of the Late Cretaceous ore-magmatic centres in the Central Srednogorie, Bulgaria. In: Bogdanov, K., Strashimirov, S. (eds.) Cretaceous porphyry-epithermal systems of the Srednogorie zone, Bulgaria: SEG Guidebook Series, 27-46.

Kamenov, B., Yanev, Y., Nedialkov, R., Moritz, R., Peytcheva, I., Von Quadt, A., Stoykov, S., Zartova, A., 2007. Petrology of Upper Cretaceous island-arc ore-magmatic centers from Central Srednogorie, Bulgaria: Magma evolution and paths. Geochemistry, Mineralogy and Petrology 45, 39-77.

Kaz'min, V. G., Tikhonova, N. F., 2006. Late Cretaceous-Eocene marginal seas in the Black Sea-Caspian region: paleotectonic reconstructions. Geotectonics 40, 169-182.

Krogh, T. E., 1973. Low-contamination method for hydrothermal decomposition of zircon and extraction of $\mathrm{U}$ and $\mathrm{Pb}$ for isotopic age determinations. Geochimica et Cosmochimica Acta 37, 485-494.

Krogh, T. E., 1982. Improved accuracy of U-Pb zircon ages by the creation of more concordant systems using an air abrasion technique. Geochimica et Cosmochimica Acta 46, 637-649.

Kunchev, I., 1966. Mediterranean type Upper Cretaceous in the Luda Kamchya part of the East Stara Planina. Izvestija NIGI 3, 45-70 (in Bulgarian).

Lilov, P., Maliakov, Y. and Balogh, K., 2004. K-Ar dating of metamorphic rocks from Strandja massif, SE Bulgaria. Geochemistry, mineralogy and petrology, 41, 107-120.

Ludwig, K. R., 1980. Calculation of uncertainties of U-Pb isotope data. Earth and Planetary Science Letters 46, 212-220.

Ludwig, K. R., 1991. ISOPLOT: A plotting program for radiogenic isotope data. U.S. Geological Survey Open-file Report 39.

Ludwig, K. R., 2003. User's manual for Isoplot 3.00. A geochronological toolkit for Microsoft Excel. Berkeley Geochronology Center Special Publication 4.

Marchev, P., Georgiev, S., Zajacz, Z., Raycheva, R., Manetti, P., von Quadt, A., Tomassini, S., 2009. High-K ankaramitic melt inclusions and lavas in the Upper Cretaceous Eastern Srednogorie continental arc, Bulgaria: Implications for the genesis of arc shoshonites. Lithos 113; 228-245.

Marchev, P., Von Quadt, A., Peytcheva, I., Ovtcharova, M., 2006. The age and origin of the Chuchuliga and Rozino granites, Eastern Rhodopes. Geosciences 2006. Sofia, Bulgaria, 213-216. 
Mattinson, J. M., 2005. Zircon U-Pb chemical abrasion ("CA-TIMS") method: Combined annealing and multi-step partial dissolution analysis for improved precision and accuracy of zircon ages. Chemical Geology 220, 47-66.

Mitchell, A.H.G., 1996. Distribution and genesis of some epizonal $\mathrm{Zn}-\mathrm{Pb}$ and Au provinces in the Carpathian-Balkan region. Transactions of the Institution of Mining and Metallurgy (Section B: Applied Earth Sciences) 105, 127- 138.

Moore, W., McKee, E., Akinci, O., 1980. Chemistry and chronology of plutonic rocks in the Pontide mountains, northern Turkey. European Copper Deposits Congress Book. Belgrade, 209-216.

Nachev, I., Dimitrova, E., 1995a. Upper Cretaceous stratigraphy of the Eastern Balkan Mountains. Geologica Balcanica 25, 43-74.

Nachev, I., Dimitrova, E., 1995b. Upper Cretaceous stratigraphy of the Eastern Sredna Gora zone. Geologica Balcanica 25, 3-26.

Nachev, I., Nachev, C., 2003. Alpine plate-tectonic of Bulgaria. Sofia: Artik 2001., 198 pp. Neubauer, F., 2002. Contrasting Late Cretaceous with Neogene ore provinces in the Alpine-Balkan-Carpathian-Dinaride collision belt. In: Blundell, D. J., Neubauer, F., von Quadt, A. (eds.) The Timing and Location of Major Ore Deposits in an Evolving Orogen, 81102.

Neubauer F., Bilyarski S., Genser J., Ivanov Z., Peytcheva I., von Quadt A., 2010. Jurassic and Cretaceous tectonic evolution of the Sakar and Srednogorie zones, Bulgaria: ${ }^{40} \mathrm{Ar} /{ }^{39} \mathrm{Ar}$ mineral ages and structures. Geologica Balcanica, CBGA 2010 meeting, Thessaloniki, abstract volume, 273-274

Nikishin, A. M., Korotaev, M. V., Ershov, A. V., Brunet, M. F., 2003. The Black Sea basin: tectonic history and Neogene-Quaternary rapid subsidence modelling. Sedimentary Geology 156, 149-168.

Nikishin, A. M., Ziegler, P. A., Panov, D. I., Nazarevich, B. P., Brunet, M. F., Stephenson, R. A., Bolotov, S. N., Korotaev, M. V., Tikhomirov, P. L., 2001. Mesozoic and Cainozoic evolution of the Scythian platform - Black Sea - Caucasus domain. In: P.A.Ziegler, Cavazza, W., Robertson, A. H. F., Crasquin-Soleau, S. (eds.) Peri-Tethys Memoir 6: Peri-Tethyan Rift/Wrench Basins and Passive Margins. Memoires du Museum National d'Histoire Naturelle, 186, 295-346.

Nozharov, P., Yosifov, D., Dolapchieva, M., Petkov, N., 1984. Late Alpine paleogeodynamic of the Srednogorie inferred from paleomagnetic data. Bulletin Research Institute Mineral Resources 1, 272-277.

Ogg, J.G., Ogg, G., Gradstein, F.M., 2008. The Concise Geologic Time Scale. Oxford University Press, $184 \mathrm{p}$.

Okay, A. I., Satir, M., Tüysüz, O., Akyüz, S., Chen, F., 2001. The tectonics of the Strandja Massif: late-Variscan and mid-Mesozoic deformation and metamorphism in the northern Aegean. International Journal of Earth Sciences 90, 217-233.

Okay, A. I., Şengör, A. M. C., Görür, N., 1994. Kinematic history of the opening of the Black Sea and its effect on the surrounding regions. Geology 22, 267-270.

Ovtcharova, M., von Quadt, A., Cherneva, Z., Sarov, S., Heinrich, C., Peytcheva, I., 2004. U$\mathrm{Pb}$ dating of zircon and monazite from granitoids and migmatites in the core and eastern periphery of the Central Rhodopean Dome, Bulgaria. Geochimica et Cosmochimica Acta 68, A664.

Öztunali, Ö., Satir, M., 1975. Rubidium-strontium alterbestimungen des Tiefengesteinen as Çavuşbaşi (Istanbul). Istanbul Üniversiteti Fen Fakültesi Mecmuast Seri B.

Peytcheva, I., von Quadt, A., 1995. U-Pb zircon dating of metagranites from Byala-reka region in the East Rhodopes, Bulgaria. Procedings of XV Congress GBGA, Geoogical Society of Greece Special Publication 4, 627-631.

Peytcheva, I., von Quadt, A., 2004. The Palaeozoic protoliths of Central Srednogorie, Bulgaria: records in zircons from basement rocks and Cretaceous magmatites. 5th International Symposium on Eastern Mediterranean Geology. Thessaloniki, Greece, 392395. 
Peytcheva, I., von Quadt, A., Ovtcharova, M., Handler, R., Neubauer, F., Salnikova, E., Kostitsyn, Y., Sarov, S., Kolcheva, K., 2004. Metagranitoids from the eastern part of the Central Rhodopean dome (Bulgaria): U-Pb, Rb-Sr and ${ }^{40} \mathrm{Ar} /{ }^{39} \mathrm{Ar}$ timing of emplacement and exhumation and isotope-geochemical features. Mineralogy and Petrology 82, 1-31.

Peytcheva, I., von Quadt, A., Georgiev, N., Ivanov, Z., Heinrich, C. A., Frank,

M., 2008. Combining trace-element compositions, U-Pb geochronology

and $\mathrm{Hf}$ isotopes in zircons to unravel complex calcalkaline magma chambers as inferred by mixed gabbros and granodiorites in the Upper Cretaceous Srednogorie zone (Bulgaria). Lithos 104, 405-427

Peytcheva, I., von Quadt, A., Neubauer, F., Frank, M., Nedialkov, R., Heinrich, C., Strashimirov, S., 2009. U-Pb dating, Hf-isotope characteristics and trace-REE-patterns of zircons from Medet porphyry copper deposit, Bulgaria: implications for timing, duration and sources of ore-bearing magmatism. - Mineralogy and Petrology 96, 19-41.

Popov, P., 1981. Magmotectonic features of the Banat-Srednogorie belt. Geologica Balcanica 11, 43-72.

Popov, P., 1987. Tectonics of the Banat Srednogorie rift. Tectonophysics 143, 209-216. Popov, P., 1996. Characteristic features of the Banat-Srednogorie metallogenic zone. "Plate Tectonic Aspects of the Alpine Metallogeny in the Carpatho-Balkan Region", IGCP Project No. 356. Annual Meet. Sofia 1996, 1, 137-154.

Popov, P., Berza, T., Grubic, A., Ioane, D., 2002. Late Cretaceous Apuseni-Banat-TimokSrednogorie(ABTS) magmatic and metallogenic belt in the Carpathian-Balkan orogen. Geologica Balcanica 32, 145-162.

Ricou, L. E., Burg, J. P., Godfriaux, I., Ivanov, Z. 1998. Rhodope and Vardar: the metamorphic and the olistostromic paired belts related to the Cretaceous subduction under Europe. Geodinamica Acta 11, 285-309.

Rocholl, A., Dulski, P., Raczek, I., 2000. New ID-TIMS, ICP-MS and SIMS data on the trace element composition and homogeneity of NIST certified reference material SRM 610-611. Geostandards Newsletter 24, 261-274.

Roussanov, I., Pchelarov, V., 1998. Phanerozoic terranes and megastutures of the Balkan peninsula. Geology and Mineral Resources 1, 36-42.

Schmid, S. M., Bernoulli, D., Fugenschuh, B., Matenco, L., Schefer, S., Schuster, R., Tischler, M., Ustaszewski, K., 2008. The Alpine-Carpathian-Dinaridic orogenic system: correlation and evolution of tectonic units. Swiss Journal of Geosciences 101, 139-183.

Slama, J., Kosler, J., Crowley, J. L., Gerdes, A., Hanchar, J., Horstwood, M., Morris, G. A., Nasdala, L., Norberg, N., Schaltegger, U., Tubrett, M. N., Whitehouse, M. J., 2008. Plešovice zircon - a new natural reference material for $\mathrm{U}-\mathrm{Pb}$ and $\mathrm{Hf}$ isotopic microanalysis. Chemical Geology 249, 1-35.

Stacey, J. S., Kramers, J. D., 1975. Approximation of terrestrial lead isotope evolution by a 2-stage model. Earth and Planetary Science Letters 26, 207-221.

Stampfli, G. M., Borel, G., 2004. The TRANSMED transect in space and time: constraints on the paleotectonic evolution of the Mediterranean domain. In: Cawazza, W., Roure, F., Spakman, W., Stampfli, G. M., Ziegler, P. (eds.) The TRANSMED Atlas: the Mediterranean Region from Crust to Mantle. Berlin: Springer Verlag, 53-90.

Stanisheva-Vassileva, G., 1980. The Upper Cretaceous magmatism in Srednogorie zone, Bulgaria: a classification attempt and some implications. Geologica Balcanica 10, 15-36.

Stanisheva-Vassileva, G., 1989. East Srednogorie volcano-intrusive area. In: StanishevaVassileva, G., Strashimirov, S., Yanev, Y. (eds.) Alpine magmatism and related metallogeny in Srednogorie and Eastern Rhodopes-XIV Congress Carpatho-Balkan Geological Association, Sofia, Field Trip Guide Book. Sofia: Sofia University, 27-38 (in Russian).

Starostenko, V., Buryanov, V., Makarenko, I., Rusakov, O., Stephenson, R., Nikishin, A., Georgiev, G., Gerasimov, M., Dimitriu, R., Legostaeva, O., Pehelarov, V. and Sava, C., 2004. Topography of the crust-mantle boundary beneath the Black Sea Basin. Tectonophysics, 381(1-4), 211-233. 
Stern, R. A., Amelin, Y., 2003. Assessment of errors in SIMS zircon U-Pb geochronology using a natural zircon standard and NIST SRM 610 glass. Chemical Geology 197, 111-142. Sunal, G., Satir, M., Natal'in, B.A., Topuz, G. and Vonderschmidt, O., 2011. Metamorphism and diachronous cooling in a contractional orogen: the Strandja Massif, NW Turkey. Geological Magazine 148 (4), 580-596.

Turpaud, Ph., Reischmann, Th., 2009. Characterisation of igneous terranes by zircon dating: implications for UHP occurrences and suture identification in the Central Rhodope, northern Greece. International Journal of Earth Sciences 99, 567-591.

von Quadt, A., Moritz, R., Peytcheva, I., Heinrich, C. A., 2005. Geochronology and geodynamics of Late Cretaceous magmatism and $\mathrm{Cu}-\mathrm{Au}$ mineralization in the Panagyurishte region of the Apuseni-Banat-Timok-Srednogorie belt, Bulgaria. Ore Geology Reviews 27, 95-126.

von Quadt,A., Sarov, St., Peytcheva, I., Voinova, E., Georgiev,N., 2009. Jurassic metagranitoids south of the West-Rhodope batholith - conventional and in situ U-Pb zircon analyses, Sr-Nd-Hf isotope tracing and geodynamic constraints. Geosciences 2009. Sofia, Bulgaria, 11-12.

von Quadt,A., Erni, M., Martinek, K., Peytcheva, I., Moll, M., Heinrich, C.A., 2011. Zircon crystallization and the life times of magmatic-hydrothermal ore systems. Geology 39 (8), 731-734.

Wiedenbeck, M., Alle, P., Corfu, F., Griffin, W. L., Meier, M., Oberli, F., von Quadt, A., Roddick, J. C., Speigel, W., 1995. Natural zircon standards for U-Th-Pb, Lu-Hf, trace-element and REE analyses. Geostandards newsletter 19, 1-23.

Yanev, S., 2000. Palaeozoic terranes of the Balkan Peninsula in the framework of Pangea assembly. Palaeogeography Palaeoclimatology Palaeoecology 161 (1-2), 151-177.

Yosifov, D., Mirlin, E., Valjashko, G., Pchelarov, V., Brusilovskii, J., 1986. A possible spreading phase in the development of the Srednogorie rift (according to geophysical data). Geologica Balcanica 16, 3-14 (in Russian, with English abstract).

Yosifov, D., Pchelarov, V., 1977. A scheme of the thickness of the Earth's crust in the Balkan Peninsula and some features of its structures. Geologica Balcanica 7, 7-22 (in Russian, with English abstract).

Zagorčev, I., Moorbath., 1983. Rubidium-strontium isotope data on the age of Dautovski pluton (Pirin type granodiorites), southwest Bulgaria. Geologica Balcanica 17, 59-71 (in Russian, with English abstract).

Zimmerman, A., Stein, H. J., Hannah, J. L., Koželj, D., Bogdanov, K., Berza, T., 2008. Tectonic configuration of the Apuseni-Banat-Timok-Srednogorie belt, Balkans-South Carpathians, constrained by high precision Re-Os molybdenite ages. Mineralium Deposita 43, 1-21.

Zonenshain, L. P., Le Pichon, X., (1986). Deep basins of the Black Sea and Caspian Sea as remnants of mesozoic back-arc basins. Tectonophysics 123, 181-211. 
Appendix 1.

Appendix 1. U-Pb zircon analyses by ID-TIMS Abbreviations: Abr - level of pre-treatment where "na" is lack of pre-tratment, "aa" - air abrasion (with the time of air abrasion pecified);"ca" - chemical abrasion. $2 \sigma$ is the standard analytical error. Str-Strandzha region; YB - YambolBurgas region; NB - North Burgas region; EB - East Balkan region.

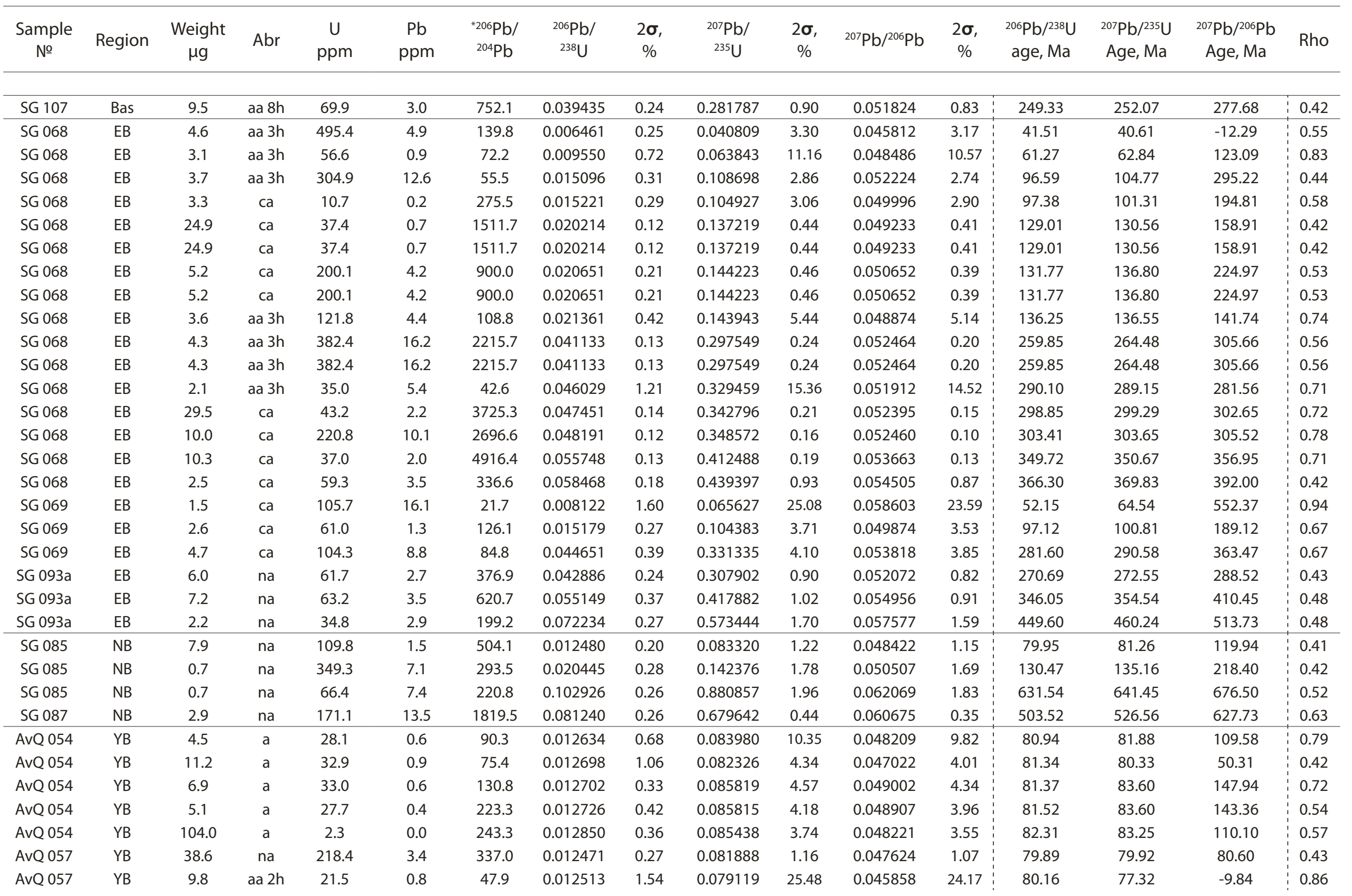


Appendix 1.

\begin{tabular}{|c|c|c|c|c|c|c|c|c|c|c|c|c|c|c|c|c|}
\hline $\begin{array}{l}\text { Sample } \\
\text { № }\end{array}$ & Region & $\begin{array}{c}\text { Weight } \\
\mu \mathrm{g}\end{array}$ & Abr & $\begin{array}{c}U \\
\mathrm{ppm}\end{array}$ & $\begin{array}{c}\mathrm{Pb} \\
\mathrm{ppm}\end{array}$ & $\begin{array}{l}{ }^{* 206} \mathrm{~Pb} / \\
{ }^{204} \mathrm{~Pb}\end{array}$ & $\begin{array}{l}{ }^{206} \mathrm{~Pb} / \\
{ }^{238} \mathrm{U}\end{array}$ & $\begin{array}{c}2 \sigma \\
\%\end{array}$ & $\begin{array}{l}{ }^{207} \mathrm{~Pb} / \\
{ }^{235} \mathrm{U}\end{array}$ & $\begin{array}{c}2 \boldsymbol{\sigma}, \\
\%\end{array}$ & ${ }^{207} \mathrm{~Pb} /{ }^{206} \mathrm{~Pb}$ & $\begin{array}{c}2 \sigma \\
\%\end{array}$ & $\begin{array}{c}{ }^{206} \mathrm{~Pb} /{ }^{238} \mathrm{U} \\
\text { age, } \mathrm{Ma}\end{array}$ & $\begin{array}{c}{ }^{207} \mathrm{~Pb} /{ }^{235} \mathrm{U} \\
\mathrm{Age}, \mathrm{Ma}\end{array}$ & $\begin{array}{c}{ }^{207} \mathrm{~Pb} /{ }^{206} \mathrm{~Pb} \\
\mathrm{Age}, \mathrm{Ma}\end{array}$ & Rho \\
\hline AvQ 057 & YB & 7.5 & & 17.2 & 0.8 & 78.2 & 0.025168 & 0.45 & 0.173601 & 4.99 & 0.050027 & 4.73 & 160.23 & 162.54 & 196.24 & 0.61 \\
\hline AvQ 057 & YB & 4.6 & na & 86.8 & 8.2 & 71.6 & 0.044321 & 0.36 & 0.315997 & 5.03 & 0.051710 & 4.74 & 279.56 & 278.82 & 272.59 & 0.81 \\
\hline AvQ 057 & YB & 6.2 & na & 24.3 & 2.7 & 61.4 & 0.045351 & 1.09 & 0.830587 & 6.30 & 0.132829 & 5.37 & 285.92 & 613.94 & 2135.71 & 0.88 \\
\hline AvQ 057 & YB & 2.3 & aa $2 \mathrm{~h}$ & 241.9 & 16.5 & 447.5 & 0.064575 & 0.34 & 0.492252 & 0.93 & 0.055287 & 0.82 & 403.39 & 406.44 & 423.86 & 0.49 \\
\hline AvQ 057 & YB & 3.6 & na & 80.0 & 8.6 & 107.0 & 0.064629 & 0.27 & 0.489436 & 2.56 & 0.054925 & 2.40 & 403.71 & 404.53 & 409.12 & 0.62 \\
\hline AvQ 057 & YB & 2.6 & na & 690.3 & 49.6 & 965.5 & 0.071794 & 0.22 & 0.560381 & 0.52 & 0.056610 & 0.45 & 446.96 & 451.77 & 476.38 & 0.52 \\
\hline AvQ 057 & YB & 3.9 & & 40.9 & 3.7 & 213.8 & 0.072789 & 0.25 & 0.561907 & 1.12 & 0.055988 & 1.04 & 452.94 & 452.77 & 451.87 & 0.45 \\
\hline AvQ 057 & YB & 16.7 & & 21.7 & 1.6 & 1061.5 & 0.073264 & 0.28 & 0.571649 & 0.54 & 0.056590 & 0.44 & 455.79 & 459.08 & 475.55 & 0.59 \\
\hline AvQ 057 & YB & 12.7 & & 68.7 & 5.0 & 1778.1 & 0.074322 & 0.26 & 0.576971 & 0.40 & 0.056304 & 0.30 & 462.14 & 462.51 & 464.37 & 0.68 \\
\hline AvQ 057 & YB & 3.5 & aa $2 \mathrm{~h}$ & 34.1 & 3.3 & 247.1 & 0.076469 & 0.61 & 0.600882 & 3.25 & 0.056991 & 3.01 & 475.01 & 477.79 & 491.17 & 0.47 \\
\hline AvQ 057 & YB & 14.0 & & 55.6 & 5.6 & 491.2 & 0.094392 & 0.33 & 0.855909 & 0.54 & 0.065765 & 0.40 & 581.46 & 627.89 & 798.90 & 0.67 \\
\hline AvQ 058 & YB & 3.5 & na & 84.9 & 4.2 & 246.7 & 0.046990 & 0.29 & 0.341759 & 2.98 & 0.052749 & 2.83 & 296.01 & 298.50 & 318.00 & 0.55 \\
\hline AvQ 058 & YB & 1.1 & aa $2 \mathrm{~h}$ & 164.0 & 8.6 & 307.8 & 0.047832 & 0.62 & 0.352250 & 2.29 & 0.053411 & 2.10 & 301.20 & 306.41 & 346.33 & 0.42 \\
\hline AvQ 058 & YB & 1.6 & aa $2 \mathrm{~h}$ & 43.8 & 3.1 & 72.3 & 0.071717 & 0.63 & 0.577328 & 10.25 & 0.058385 & 9.73 & 446.49 & 462.74 & 544.21 & 0.85 \\
\hline AvQ 058 & YB & 2.8 & aa $2 \mathrm{~h}$ & 105.7 & 11.5 & 191.7 & 0.100186 & 0.28 & 1.290945 & 1.59 & 0.093454 & 1.45 & 615.50 & 841.72 & 1497.10 & 0.55 \\
\hline SG 044 & YB & 3.3 & aa $3 \mathrm{~h}$ & 589.5 & 12.4 & 145.1 & 0.012354 & 0.19 & 0.080022 & 1.63 & 0.046978 & 1.55 & 79.15 & 78.17 & 48.06 & 0.49 \\
\hline SG 044 & YB & 5.5 & aa $3 \mathrm{~h}$ & 525.1 & 8.3 & 429.1 & 0.012370 & 0.13 & 0.082117 & 0.43 & 0.048147 & 0.40 & 79.25 & 80.13 & 106.50 & 0.41 \\
\hline SG 044 & YB & 13.5 & aa $3 \mathrm{~h}$ & 668.1 & 9.4 & 2400.5 & 0.012371 & 0.14 & 0.081569 & 0.18 & 0.047820 & 0.11 & 79.26 & 79.62 & 90.36 & 0.79 \\
\hline SG 044 & YB & 3.4 & aa $3 \mathrm{~h}$ & 742.8 & 11.2 & 766.2 & 0.012404 & 0.20 & 0.082237 & 0.45 & 0.048084 & 0.39 & 79.47 & 80.25 & 103.42 & 0.47 \\
\hline SG 044 & YB & 3.7 & aa $3 \mathrm{~h}$ & 186.6 & 4.0 & 107.8 & 0.012445 & 0.18 & 0.081677 & 1.88 & 0.047598 & 1.78 & 79.73 & 79.72 & 79.38 & 0.58 \\
\hline SG 044 & YB & 2.1 & $\begin{array}{l}\text { aa } \\
3 \mathrm{~h}\end{array}$ & 1128.7 & 19.8 & 264.5 & 0.012470 & 0.17 & 0.083206 & 0.90 & 0.048395 & 0.87 & 79.89 & 81.15 & 118.59 & 0.27 \\
\hline SG 044 & YB & 5.0 & aa $3 \mathrm{~h}$ & 493.2 & 11.3 & 101.9 & 0.012598 & 0.26 & 0.082580 & 2.96 & 0.047541 & 2.80 & 80.71 & 80.57 & 76.51 & 0.63 \\
\hline SG 044b & YB & 2.3 & na & 150.6 & 3.9 & 71.9 & 0.012406 & 1.09 & 0.081772 & 15.02 & 0.047806 & 14.21 & 79.48 & 79.81 & 89.68 & 0.76 \\
\hline SG 044b & YB & 6.6 & na & 150.3 & 2.8 & 581.3 & 0.013538 & 0.29 & 0.090690 & 0.88 & 0.048584 & 0.79 & 86.69 & 88.15 & 127.75 & 0.45 \\
\hline SG 044b & YB & 2.1 & na & 19.0 & 2.0 & 94.9 & 0.071224 & 0.44 & 0.572863 & 4.74 & 0.058334 & 4.46 & 443.53 & 459.86 & 542.35 & 0.66 \\
\hline SG 044b & YB & 4.0 & na & 18.9 & 3.4 & 703.4 & 0.174703 & 0.44 & 1.789964 & 0.72 & 0.074309 & 0.54 & 1037.97 & 1041.81 & 1049.87 & 0.67 \\
\hline SG 063 & YB & 7.8 & aa $6 \mathrm{~h}$ & 18.9 & 0.7 & 216.0 & 0.027056 & 0.20 & 0.193838 & 2.17 & 0.051960 & 2.08 & 172.10 & 179.90 & 283.65 & 0.47 \\
\hline SG 063 & YB & 2.6 & aa $6 \mathrm{~h}$ & 42.4 & 2.2 & 93.4 & 0.030615 & 0.26 & 0.225683 & 3.66 & 0.053464 & 3.48 & 194.40 & 206.63 & 348.54 & 0.68 \\
\hline SG 063 & YB & 4.3 & aa $6 \mathrm{~h}$ & 21.3 & 1.3 & 678.7 & 0.063063 & 0.17 & 0.483446 & 0.88 & 0.055599 & 0.82 & 394.23 & 400.43 & 436.43 & 0.42 \\
\hline SG 063 & YB & 5.8 & aa $6 \mathrm{~h}$ & 33.7 & 2.6 & 447.1 & 0.068411 & 0.30 & 0.577459 & 0.84 & 0.061220 & 0.76 & 426.57 & 462.83 & 646.97 & 0.43 \\
\hline SG 063 & YB & 8.7 & aa $6 \mathrm{~h}$ & 46.6 & 3.7 & 786.0 & 0.075881 & 0.15 & 0.598451 & 0.30 & 0.057200 & 0.25 & 471.49 & 476.25 & 499.24 & 0.57 \\
\hline SG 102d & YB & 6.2 & aa $6 \mathrm{~h}$ & 147.8 & 9.3 & 32.1 & 0.012067 & 0.81 & 0.073557 & 15.32 & 0.044210 & 14.60 & 77.32 & 72.07 & -98.98 & 0.89 \\
\hline SG 102d & YB & 4.6 & aa $6 \mathrm{~h}$ & 178.3 & 2.6 & 330.3 & 0.012222 & 0.24 & 0.082757 & 1.70 & 0.049110 & 1.60 & 78.31 & 80.73 & 153.03 & 0.47 \\
\hline SG 102d & YB & 6.8 & aa $6 \mathrm{~h}$ & 135.2 & 1.9 & 578.3 & 0.012428 & 0.21 & 0.082602 & 1.02 & 0.048205 & 0.95 & 79.62 & 80.59 & 109.31 & 0.40 \\
\hline SG 103 & $\mathrm{YB}$ & 2.8 & aa $8 \mathrm{~h}$ & 142.8 & 2.4 & 169.9 & 0.012516 & 0.27 & 0.084435 & 2.48 & 0.048926 & 2.35 & 80.19 & 82.31 & 144.26 & 0.53 \\
\hline AvQ 046 & Str & 6.9 & aa $2 \mathrm{~h}$ & 217.1 & 4.0 & 133.2 & 0.012349 & 0.22 & 0.081354 & 2.38 & 0.047779 & 2.25 & 79.12 & 79.42 & 88.33 & 0.63 \\
\hline AvQ 046 & Str & 1.7 & aa $2 \mathrm{~h}$ & 1005.1 & 14.6 & 327.0 & 0.013228 & 0.39 & 0.086616 & 2.86 & 0.047492 & 2.69 & 84.71 & 84.35 & 73.98 & 0.48 \\
\hline
\end{tabular}




\begin{tabular}{|c|c|c|c|c|c|c|c|c|c|c|c|c|c|c|c|c|}
\hline $\begin{array}{c}\text { Sample } \\
\text { № }\end{array}$ & Region & $\begin{array}{l}\text { Weight } \\
\mu \mathrm{g}\end{array}$ & Abr & $\underset{\mathrm{ppm}}{U}$ & $\begin{array}{c}\mathrm{Pb} \\
\mathrm{ppm}\end{array}$ & $\begin{array}{l}{ }^{{ }^{206}} \mathrm{~Pb} / \\
{ }^{204} \mathrm{~Pb}\end{array}$ & $\begin{array}{c}{ }^{206} \mathrm{~Pb} / \\
{ }^{238} \mathrm{U}\end{array}$ & $\begin{array}{c}2 \sigma \\
\%\end{array}$ & $\begin{array}{l}{ }^{207} \mathrm{~Pb} / \\
{ }^{235} \mathrm{U}\end{array}$ & $\begin{array}{l}2 \sigma \\
\%\end{array}$ & ${ }^{207} \mathrm{~Pb} /{ }^{206} \mathrm{~Pb}$ & $\begin{array}{c}2 \sigma \\
\%\end{array}$ & $\begin{array}{c}{ }^{206} \mathrm{~Pb} /{ }^{238} \mathrm{U} \\
\text { age, } \mathrm{Ma}\end{array}$ & $\begin{array}{c}{ }^{207} \mathrm{~Pb} /{ }^{235} \mathrm{U} \\
\text { Age, } \mathrm{Ma}\end{array}$ & $\begin{array}{c}{ }^{207} \mathrm{~Pb} /{ }^{206} \mathrm{~Pb} \\
\mathrm{Age}, \mathrm{Ma}\end{array}$ & Rho \\
\hline AvQ 046 & Str & 0.3 & aa $2 \mathrm{~h}$ & 1052.3 & 56.2 & 40.2 & 0.014440 & 0.37 & 0.095074 & 5.74 & 0.047752 & 5.46 & 92.42 & 92.22 & 86.97 & 0.78 \\
\hline AvQ 046 & Str & 2.3 & aa $2 \mathrm{~h}$ & 144.2 & 4.6 & 78.4 & 0.016332 & 2.40 & 0.113560 & 37.42 & 0.050428 & 35.88 & 104.44 & 109.22 & 214.77 & 0.66 \\
\hline AvQ 048 & Str & 12.0 & aa & 623.8 & 8.1 & 607.2 & 0.012184 & 0.19 & 0.079905 & 0.87 & 0.047567 & 0.82 & 78.07 & 78.06 & 77.75 & 0.39 \\
\hline AvQ 048 & Str & 8.2 & aa & 561.2 & 9.2 & 192.1 & 0.012247 & 0.22 & 0.081155 & 1.63 & 0.048059 & 1.53 & 78.47 & 79.23 & 102.22 & 0.49 \\
\hline AvQ 048 & Str & 3.9 & $\mathrm{ca}$ & 189.0 & 5.8 & 58.1 & 0.012385 & 0.23 & 0.084241 & 2.17 & 0.049333 & 2.07 & 79.35 & 82.12 & 163.71 & 0.47 \\
\hline AvQ 048 & Str & 11.2 & $\mathrm{ca}$ & 172.3 & 2.6 & 265.4 & 0.012452 & 0.43 & 0.082965 & 0.86 & 0.048324 & 0.73 & 79.77 & 80.93 & 115.13 & 0.53 \\
\hline AvQ 048 & Str & 12.0 & $\mathrm{ca}$ & 155.7 & 2.5 & 213.3 & 0.012455 & 0.54 & 0.083107 & 1.10 & 0.048393 & 0.94 & 79.80 & 81.06 & 118.59 & 0.51 \\
\hline AvQ 048 & Str & 9.7 & aa $2 \mathrm{~h}$ & 281.0 & 4.1 & 324.3 & 0.012467 & 0.13 & 0.081910 & 0.50 & 0.047651 & 0.46 & 79.87 & 79.94 & 81.95 & 0.43 \\
\hline AvQ 048 & Str & 9.0 & aa $2 \mathrm{~h}$ & 296.2 & 4.3 & 320.8 & 0.012469 & 0.28 & 0.082110 & 0.63 & 0.047758 & 0.54 & 79.89 & 80.13 & 87.28 & 0.52 \\
\hline AvQ 048 & Str & 4.2 & $\mathrm{ca}$ & 127.9 & 2.0 & 171.5 & 0.012472 & 0.52 & 0.082291 & 5.21 & 0.047855 & 4.96 & 79.90 & 80.30 & 92.09 & 0.52 \\
\hline AvQ 048 & Str & 7.8 & $\mathrm{ca}$ & 164.8 & 2.2 & 552.0 & 0.012510 & 0.18 & 0.083458 & 0.86 & 0.048387 & 0.83 & 80.14 & 81.39 & 118.21 & 0.29 \\
\hline AvQ 048 & Str & 17.7 & $\mathrm{ca}$ & 213.3 & 3.4 & 225.9 & 0.012666 & 0.39 & 0.082937 & 1.06 & 0.047492 & 0.94 & 81.14 & 80.90 & 74.03 & 0.48 \\
\hline AvQ 048 & Str & 3.8 & aa $2 \mathrm{~h}$ & 144.3 & 2.7 & 281.2 & 0.015623 & 0.39 & 0.106300 & 2.30 & 0.049349 & 2.16 & 99.93 & 102.57 & 164.45 & 0.45 \\
\hline AvQ 048 & Str & 4.7 & aa $2 \mathrm{~h}$ & 127.1 & 3.2 & 110.7 & 0.015812 & 0.23 & 0.107585 & 2.44 & 0.049347 & 2.32 & 101.13 & 103.75 & 164.38 & 0.54 \\
\hline AvQ 048 & Str & 7.4 & aa & 249.9 & 5.8 & 152.7 & 0.016351 & 0.19 & 0.111098 & 1.47 & 0.049280 & 1.38 & 104.55 & 106.97 & 161.16 & 0.51 \\
\hline AvQ 048 & Str & 4.2 & aa & 112.5 & 2.8 & 185.9 & 0.018247 & 2.25 & 0.136898 & 21.76 & 0.054414 & 20.46 & 116.57 & 130.28 & 388.23 & 0.61 \\
\hline AvQ 048 & Str & 10.5 & aa & 307.6 & 6.9 & 447.8 & 0.020303 & 0.27 & 0.139130 & 1.55 & 0.049699 & 1.44 & 129.57 & 132.27 & 180.98 & 0.45 \\
\hline AvQ 050 & Str & 18.2 & aa $7 \mathrm{~h}$ & 181.4 & 2.9 & 714.4 & 0.012625 & 0.17 & 0.083185 & 0.33 & 0.047788 & 0.28 & 80.88 & 81.13 & 88.78 & 0.56 \\
\hline AvQ 050 & Str & 22.8 & aa $7 \mathrm{~h}$ & 192.6 & 2.9 & 706.9 & 0.012637 & 0.19 & 0.083484 & 0.47 & 0.047913 & 0.43 & 80.95 & 81.42 & 95.01 & 0.43 \\
\hline AvQ 050 & Str & 32.1 & aa $7 \mathrm{~h}$ & 185.4 & 3.1 & 696.7 & 0.012638 & 0.51 & 0.083683 & 0.66 & 0.048026 & 0.41 & 80.96 & 81.60 & 100.57 & 0.78 \\
\hline AvQ 051 & Str & 7.2 & aa $7 \mathrm{~h}$ & 105.7 & 2.2 & 124.2 & 0.012415 & 0.19 & 0.080621 & 2.07 & 0.047098 & 1.96 & 79.54 & 78.73 & 54.27 & 0.60 \\
\hline AvQ 051 & Str & 24.7 & aa $7 \mathrm{~h}$ & 76.8 & 1.3 & 326.1 & 0.012449 & 0.30 & 0.081257 & 2.20 & 0.047338 & 2.08 & 79.76 & 79.33 & 66.28 & 0.49 \\
\hline AvQ 051 & Str & 13.9 & aa $7 \mathrm{~h}$ & 121.0 & 2.2 & 302.9 & 0.012477 & 0.15 & 0.081768 & 0.69 & 0.047530 & 0.64 & 79.94 & 79.81 & 75.89 & 0.42 \\
\hline AvQ 051 & Str & 8.5 & aa $7 \mathrm{~h}$ & 49.9 & 1.1 & 95.3 & 0.012562 & 0.22 & 0.089094 & 2.24 & 0.051440 & 2.16 & 80.47 & 86.66 & 260.59 & 0.38 \\
\hline AvQ 051 & Str & 12.1 & aa $7 \mathrm{~h}$ & 139.9 & 2.3 & 524.6 & 0.014019 & 0.24 & 0.094845 & 0.66 & 0.049069 & 0.61 & 89.74 & 92.01 & 151.14 & 0.41 \\
\hline AvQ 051 & Str & 19.7 & aa $7 \mathrm{~h}$ & 85.6 & 3.0 & 1496.4 & 0.032830 & 0.17 & 0.235510 & 0.25 & 0.052027 & 0.17 & 208.24 & 214.74 & 286.60 & 0.71 \\
\hline AvQ 052 & Str & 41.6 & aa $6 \mathrm{~h}$ & 174.5 & 2.2 & 1801.9 & 0.012416 & 0.15 & 0.081821 & 0.24 & 0.047797 & 0.18 & 79.54 & 79.86 & 89.23 & 0.66 \\
\hline AvQ 052 & Str & 4.5 & aa $6 \mathrm{~h}$ & 267.4 & 3.6 & 820.6 & 0.012430 & 0.37 & 0.082375 & 0.87 & 0.048064 & 0.75 & 79.64 & 80.38 & 102.37 & 0.50 \\
\hline SG 011 & Str & 8.4 & aa $6 \mathrm{~h}$ & 90.3 & 5.2 & 37.4 & 0.012987 & 9.80 & 0.080292 & 44.50 & 0.044841 & 41.39 & 83.18 & 78.42 & -64.29 & 0.42 \\
\hline SG 011 & Str & 2.8 & aa $6 \mathrm{~h}$ & 93.0 & 3.8 & 47.9 & 0.013341 & 0.45 & 0.089931 & 7.01 & 0.048889 & 6.65 & 85.43 & 87.44 & 142.52 & 0.81 \\
\hline SG 011 & Str & 12.2 & aa $6 \mathrm{~h}$ & 69.6 & 1.4 & 175.4 & 0.013471 & 0.15 & 0.089125 & 1.27 & 0.047984 & 1.23 & 86.26 & 86.69 & 98.49 & 0.30 \\
\hline SG 011 & Str & 22.7 & aa $6 \mathrm{~h}$ & 62.5 & 1.0 & 558.5 & 0.013481 & 0.33 & 0.089045 & 0.63 & 0.047904 & 0.52 & 86.33 & 86.61 & 94.53 & 0.56 \\
\hline SG 011 & Str & 13.4 & aa $6 \mathrm{~h}$ & 302.9 & 5.2 & 2807.2 & 0.013490 & 0.28 & 0.088937 & 0.46 & 0.047817 & 0.36 & 86.38 & 86.51 & 90.19 & 0.62 \\
\hline SG 021 & Str & 2.3 & aa $6 \mathrm{~h}$ & 185.6 & 6.2 & 48.5 & 0.012272 & 0.31 & 0.077540 & 5.51 & 0.045826 & 5.27 & 78.63 & 75.83 & -11.56 & 0.81 \\
\hline SG 021 & Str & 0.8 & aa $6 \mathrm{~h}$ & 163.3 & 4.1 & 45.9 & 0.012349 & 0.89 & 0.081272 & 16.59 & 0.047731 & 15.82 & 79.12 & 79.34 & 85.92 & 0.88 \\
\hline SG 021 & Str & 2.1 & na & 496.6 & 10.2 & 115.7 & 0.012357 & 0.21 & 0.082820 & 2.26 & 0.048610 & 2.14 & 79.17 & 80.79 & 129.11 & 0.62 \\
\hline SG 021 & Str & 0.2 & na & 457.0 & 36.0 & 214.8 & 0.068962 & 0.39 & 0.550288 & 1.44 & 0.057873 & 1.31 & 429.90 & 445.19 & 524.96 & 0.45 \\
\hline
\end{tabular}


Appendix 1.

\begin{tabular}{|c|c|c|c|c|c|c|c|c|c|c|c|c|c|c|c|c|}
\hline $\begin{array}{l}\text { Sample } \\
\text { № }\end{array}$ & Region & $\begin{array}{c}\text { Weight } \\
\mu \mathrm{g}\end{array}$ & Abr & $\begin{array}{c}\mathrm{U} \\
\mathrm{ppm}\end{array}$ & $\begin{array}{c}\mathrm{Pb} \\
\mathrm{ppm}\end{array}$ & $\begin{array}{l}{ }^{*} 206 \mathrm{~Pb} / \\
{ }^{204} \mathrm{~Pb}\end{array}$ & $\begin{array}{l}{ }^{206} \mathrm{~Pb} / \\
{ }^{238} \mathrm{U}\end{array}$ & $\begin{array}{c}2 \boldsymbol{\sigma} \\
\%\end{array}$ & $\begin{array}{l}{ }^{207} \mathrm{~Pb} / \\
{ }^{235} \mathrm{U}\end{array}$ & $\begin{array}{c}2 \sigma \\
\%\end{array}$ & ${ }^{207} \mathrm{~Pb} /{ }^{206} \mathrm{~Pb}$ & $\begin{array}{c}2 \boldsymbol{\sigma} \\
\%\end{array}$ & $\begin{array}{c}{ }^{206} \mathrm{~Pb} /{ }^{238} \mathrm{U} \\
\text { age, Ma }\end{array}$ & $\begin{array}{c}{ }^{207} \mathrm{~Pb} /{ }^{235} \mathrm{U} \\
\mathrm{Age}, \mathrm{Ma}\end{array}$ & $\begin{array}{c}{ }^{207} \mathrm{~Pb} /{ }^{206} \mathrm{~Pb} \\
\text { Age, Ma }\end{array}$ & Rho \\
\hline SG 028 & Str & 9.4 & aa $3 \mathrm{~h}$ & 505.7 & 6.0 & 1613.0 & 0.011999 & 0.15 & 0.079278 & 0.45 & 0.047917 & 0.41 & 76.89 & 77.47 & 95.14 & 0.41 \\
\hline SG 028 & Str & 116.0 & $\begin{array}{l}\text { aa } \\
3 \mathrm{~h}\end{array}$ & 31.0 & 0.4 & 596.6 & 0.012103 & 0.17 & 0.079798 & 0.59 & 0.047817 & 0.56 & 77.56 & 77.96 & 90.27 & 0.32 \\
\hline SG 028 & Str & 6.0 & aa $3 \mathrm{~h}$ & 284.9 & 4.7 & 164.9 & 0.012119 & 0.14 & 0.080337 & 0.96 & 0.048079 & 0.93 & 77.65 & 78.46 & 103.21 & 0.28 \\
\hline SG 028 & Str & 4.1 & aa $3 \mathrm{~h}$ & 188.9 & 2.6 & 315.9 & 0.012449 & 0.32 & 0.082604 & 3.13 & 0.048125 & 2.97 & 79.76 & 80.59 & 105.42 & 0.55 \\
\hline SG 028 & Str & 6.4 & aa $3 \mathrm{~h}$ & 249.8 & 3.7 & 486.1 & 0.013933 & 0.36 & 0.095175 & 1.62 & 0.049544 & 1.50 & 89.20 & 92.31 & 173.67 & 0.42 \\
\hline SG 028 & Str & 3.7 & aa $3 \mathrm{~h}$ & 242.0 & 5.6 & 105.7 & 0.014238 & 0.39 & 0.095998 & 4.63 & 0.048900 & 4.37 & 91.14 & 93.08 & 142.98 & 0.68 \\
\hline SG 030 & Str & 19.4 & $\mathrm{ca}$ & 109.0 & 3.7 & 589.8 & 0.030106 & 0.15 & 0.210348 & 0.38 & 0.050674 & 0.33 & 191.21 & 193.84 & 225.96 & 0.50 \\
\hline SG 030 & Str & 3.5 & na & 89.5 & 4.6 & 485.0 & 0.050263 & 0.16 & 0.371537 & 0.57 & 0.053611 & 0.52 & 316.13 & 320.79 & 354.78 & 0.43 \\
\hline SG 030 & Str & 0.8 & $\mathrm{ca}$ & 86.8 & 5.6 & 172.3 & 0.050972 & 0.36 & 0.382692 & 3.03 & 0.054453 & 2.85 & 320.48 & 329.02 & 389.79 & 0.54 \\
\hline SG 030 & Str & 0.4 & $\mathrm{ca}$ & 81.8 & 7.5 & 67.3 & 0.052973 & 0.67 & 0.403065 & 8.72 & 0.055185 & 8.22 & 332.75 & 343.87 & 419.71 & 0.76 \\
\hline SG 032 & Str & 2.9 & na & 72.8 & 3.6 & 537.2 & 0.049839 & 0.23 & 0.380508 & 0.84 & 0.055373 & 0.77 & 313.53 & 327.41 & 427.34 & 0.42 \\
\hline SG 032 & Str & 1.5 & na & 126.0 & 8.1 & 444.5 & 0.062869 & 0.27 & 0.487873 & 0.78 & 0.056282 & 0.70 & 393.05 & 403.46 & 463.52 & 0.47 \\
\hline SG 045 & Str & 12.8 & $\mathrm{ca}$ & 310.8 & 4.1 & 548.0 & 0.012433 & 0.14 & 0.081811 & 0.42 & 0.047725 & 0.38 & 79.65 & 79.85 & 85.63 & 0.46 \\
\hline SG 045 & Str & 13.1 & $\mathrm{ca}$ & 235.8 & 2.8 & 3472.1 & 0.012438 & 0.14 & 0.082195 & 0.29 & 0.047929 & 0.25 & 79.69 & 80.21 & 95.77 & 0.53 \\
\hline SG 045 & Str & 25.2 & $\mathrm{ca}$ & 122.4 & 1.7 & 2285.8 & 0.014564 & 0.13 & 0.097252 & 0.28 & 0.048429 & 0.23 & 93.21 & 94.24 & 120.26 & 0.55 \\
\hline SG 045 & Str & 5.6 & $\mathrm{ca}$ & 281.1 & 4.8 & 320.4 & 0.014774 & 0.15 & 0.099369 & 0.87 & 0.048783 & 0.82 & 94.54 & 96.19 & 137.42 & 0.43 \\
\hline SG 051 & Str & 2.1 & na & 426.8 & 19.2 & 40.5 & 0.011944 & 1.32 & 0.095941 & 16.07 & 0.058257 & 15.07 & 76.54 & 93.02 & 539.46 & 0.77 \\
\hline SG 051 & Str & 3.0 & aa $2 \mathrm{~h}$ & 191.6 & 8.6 & 69.9 & 0.021440 & 0.31 & 0.158645 & 1.85 & 0.053666 & 1.76 & 136.75 & 149.52 & 357.09 & 0.35 \\
\hline SG 051 & Str & 4.1 & aa $2 \mathrm{~h}$ & 192.2 & 7.2 & 108.8 & 0.021633 & 0.25 & 0.153903 & 1.14 & 0.051597 & 1.08 & 137.97 & 145.35 & 267.60 & 0.36 \\
\hline SG 051 & Str & 5.7 & na & 145.1 & 4.9 & 367.7 & 0.030026 & 0.21 & 0.212930 & 1.00 & 0.051433 & 0.93 & 190.71 & 196.01 & 260.28 & 0.43 \\
\hline SG 051 & Str & 2.2 & aa $2 \mathrm{~h}$ & 191.0 & 8.2 & 150.2 & 0.030422 & 0.55 & 0.216528 & 2.11 & 0.051621 & 2.01 & 193.19 & 199.02 & 268.63 & 0.30 \\
\hline SG 051 & Str & 2.6 & aa $2 \mathrm{~h}$ & 189.6 & 9.8 & 323.1 & 0.042523 & 4.43 & 0.314674 & 6.54 & 0.053670 & 4.78 & 268.46 & 277.80 & 357.19 & 0.68 \\
\hline SG 052 & Str & 0.8 & na & 705.0 & 133.3 & 531.2 & 0.011662 & 0.25 & 0.076129 & 1.46 & 0.047346 & 1.38 & 74.74 & 74.50 & 66.67 & 0.40 \\
\hline SG 052 & Str & 65.6 & aa $6 \mathrm{~h}$ & 344.2 & 4.4 & 7995.9 & 0.012113 & 0.19 & 0.081388 & 0.22 & 0.048733 & 0.11 & 77.61 & 79.45 & 135.03 & 0.87 \\
\hline SG 057 & Str & 2.5 & aa $3 \mathrm{~h}$ & 242.4 & 3.9 & 144.6 & 0.011873 & 0.26 & 0.080477 & 1.68 & 0.049160 & 1.58 & 76.09 & 78.59 & 155.45 & 0.45 \\
\hline SG 057 & Str & 4.3 & aa $3 h$ & 231.0 & 6.9 & 165.4 & 0.021584 & 0.23 & 0.145177 & 1.44 & 0.048783 & 1.35 & 137.66 & 137.64 & 137.38 & 0.46 \\
\hline SG 057 & Str & 4.2 & aa $3 h$ & 194.2 & 4.7 & 1828.6 & 0.025387 & 0.21 & 0.179774 & 0.47 & 0.051359 & 0.40 & 161.61 & 167.87 & 256.98 & 0.52 \\
\hline SG 057 & Str & 2.5 & aa $3 \mathrm{~h}$ & 97.1 & 6.4 & 75.8 & 0.034169 & 0.58 & 0.237420 & 8.19 & 0.050395 & 7.73 & 216.58 & 216.31 & 213.29 & 0.80 \\
\hline SG 057 & Str & 6.0 & aa $3 \mathrm{~h}$ & 103.9 & 6.0 & 260.2 & 0.046157 & 0.16 & 0.332327 & 0.63 & 0.052219 & 0.58 & 290.88 & 291.34 & 295.02 & 0.43 \\
\hline SG 057 & Str & 22.8 & aa $6 \mathrm{~h}$ & 132.7 & 8.6 & 5570.1 & 0.069391 & 0.13 & 0.532733 & 0.15 & 0.055681 & 0.06 & 432.48 & 433.62 & 439.69 & 0.91 \\
\hline ST 25 & Str & 7.0 & $\mathrm{ca}$ & 116.2 & 3.7 & 71.4 & 0.013513 & 0.21 & 0.091246 & 2.61 & 0.048973 & 2.48 & 86.53 & 88.66 & 146.51 & 0.60 \\
\hline ST 25 & Str & 3.8 & $\mathrm{ca}$ & 93.4 & 4.4 & 44.9 & 0.013562 & 0.44 & 0.092518 & 6.87 & 0.049476 & 6.51 & 86.84 & 89.85 & 170.43 & 0.84 \\
\hline ST 25 & Str & 11.3 & $\mathrm{ca}$ & 136.8 & 5.0 & 60.5 & 0.013573 & 0.23 & 0.091276 & 2.97 & 0.048774 & 2.81 & 86.91 & 88.69 & 136.99 & 0.71 \\
\hline ST 25 & Str & 9.4 & $\mathrm{ca}$ & 121.2 & 5.0 & 53.5 & 0.013576 & 0.24 & 0.093452 & 3.36 & 0.049923 & 3.20 & 86.93 & 90.71 & 191.42 & 0.68 \\
\hline
\end{tabular}


Appendix 1. U-Pb zircon analyses by LA-ICPMS Abbreviations : EB - East Balkan region; NB - North Balkan region; YB - YambolBurgas region; Str - Strandzha region; Bas - basement rocks; P \% - for samples where common Pb correction was applied this is the age difference in percentage between the common $\mathrm{Pb}$ corrected age, presented here and the uncorrected age; Rho-correlation coefficient ; $\mathrm{R}$ - number of readings integrated from the signal; $\mathrm{S}$ - seconds integrated from the signal ; A/In - the ratio of the age calculated using the average approach (similar to LAMTRACE program) versus the calculated age using the intercept regression approach (used in this study), i.e. this ratio is an estimation of the degree of elemental fractionation in the course of the analyses; $\mathrm{C}$ (concordance) - within their analytical errors samples marked with * cross the concordia band.

\begin{tabular}{|c|c|c|c|c|c|c|c|c|c|c|c|c|c|c|c|c|c|}
\hline \multirow{2}{*}{$\begin{array}{l}\text { sample \# } \\
\text { crystal \# }\end{array}$} & \multirow{2}{*}{\multicolumn{2}{|c|}{ Region block }} & \multirow{2}{*}{\multicolumn{2}{|c|}{$\mathbf{P} \%$}} & \multirow[b]{2}{*}{${ }^{207} \mathrm{~Pb} /{ }^{235} \mathrm{U}$} & \multicolumn{2}{|c|}{ Isotope ratios } & \multirow[b]{2}{*}{$2 \sigma, \%$} & \multirow[b]{2}{*}{ Rho } & \multirow[b]{2}{*}{${ }^{206} \mathrm{~Pb} /{ }^{238} \mathrm{U}$} & \multicolumn{2}{|c|}{ Apparent ages } & \multirow[b]{2}{*}{$2 \sigma, \mathrm{Ma}$} & \multirow[b]{2}{*}{$\mathbf{R}$} & \multirow[b]{2}{*}{$\mathbf{S}$} & \multirow[b]{2}{*}{$A / l n$} & \multirow[b]{2}{*}{ C } \\
\hline & & & & & & ,\% & & & & & & & & & & & \\
\hline G 047-cr1 & Bas & ja12e & 5 & 2.3 & 0.5409 & 13. & 0.0486 & 4.64 & 0.34 & 299.0 & 13.9 & 430.84 & $58.3 i$ & 31 & 4.2 & 1.03 & \\
\hline SG 047-cr10 & Bas & ja12e & 14 & & & 4.45 & & 2.27 & & & 7.2 & & 14.4 & 146 & 19.7 & 0.91 & \\
\hline SG 047-cr2 & Bas & a12e & 6 & & & 7.10 & & 2.06 & 0.29 & & 6.0 & & $20.6 !$ & 280 & 37.5 & 1.05 & \\
\hline G 047-cr3 & Bas & ja12e & 7 & 2.4 & & 10.67 & & & 0.55 & & & & $48.6 !$ & 272 & 36.4 & 0.94 & \\
\hline SG 047-cr4 & as & ja12e & 8 & & & 9. & & & & & & & $31.5 !$ & 163 & 21.8 & 1.06 & \\
\hline & & ja12e & 9 & & & 10. & & & & & & & 30.8 & 185 & 24.8 & 1.08 & \\
\hline & & ja12e & 10 & & & & & 5.25 & 0.48 & & & & 277.5 & 125 & 16.8 & 1.28 & \\
\hline & & ja12e & 11 & & & & & & & & & & & 207 & 27.7 & 1.07 & \\
\hline & & ja12e & 12 & & & & & & & & & & & 67 & 9.0 & 0.98 & \\
\hline & & ja12e & 13 & & & 14. & & & & & & & $49.9 !$ & 115 & & 101 & \\
\hline & & ja12d & 5 & 4.4 & & 72. & & & & & & & & 255 & .2 & 1.40 & \\
\hline & & a12d & 17 & 2.4 & & & & & & & & & & 26 & & 14 & \\
\hline & as & ja12d & 4 & & & 8. & & & & & & & & 160 & 6 & 16 & \\
\hline & & ja12d & 6 & & & 8. & & & 0.23 & & & & & 250 & .5 & 1.02 & \\
\hline & & ja12d & 7 & & & 6. & & 1. & '3 0 & & & & & & 4.7 & 1.00 & \\
\hline & & ja12d & 8 & & & & & & 0.28 & & & & & 45 & 2.8 & 1.07 & \\
\hline & & ja12d & 10 & 4.8 & & 36. & & & 0.18 & & & & -39.5 & 120 & 16.1 & 1 & \\
\hline & & ja12d & 9 & & & & & & & & & & & 151 & 20.2 & 1 & \\
\hline & & & 11 & & & & & & & & & & & 112 & 15.0 & 1 & \\
\hline & & ja12d & 12 & & & & & & & & & & & 55 & 7.4 & 1.1 & \\
\hline & & & 14 & & & & & & & & & & & 88 & 1.8 & 1 & \\
\hline & & & 13 & & & & & & & & & & & 99 & 3 & 06 & \\
\hline & & & 16 & 2.6 & & & & & & & & & & 120 & 1 & 1.09 & \\
\hline & & ja12d & 15 & & & 134 & & & & & & & & 86 & 5 & 1.19 & \\
\hline & & $\mathrm{ma04c}$ & 4 & & & & & & & & & & & & & & \\
\hline & & $\mathrm{ma04c}$ & 6 & & & & & & & & & & & 120 & & & \\
\hline & & & 7 & 5 & & & & & & & & & & & & & \\
\hline & & & 8 & 3.6 & & & & & & & & & & 70 & & .06 & \\
\hline & & & 9 & & & & & & & & & & & 128 & & .03 & \\
\hline & & & & 1. & & & & & & & & & & 40 & .2 & 12 & \\
\hline SG C & & & 10 & 16.2 & & & & & & & & & & & & .07 & \\
\hline SG 068-cr8-r & EB & $\mathrm{ma} 04 \mathrm{c}$ & & & 0.0384 & 37.56 & 0.0076 & 9.09 & 0.24 & 48.8 & 4.4 & 38.31 & $14.4 i$ & 180 & 24.7 & 1.17 & \\
\hline
\end{tabular}


Appendix 2.

\begin{tabular}{|c|c|c|c|c|c|c|c|c|c|c|c|c|c|c|c|c|c|}
\hline \multirow{2}{*}{$\begin{array}{l}\text { sample \# } \\
\text { crystal \# }\end{array}$} & \multirow{2}{*}{\multicolumn{2}{|c|}{ Region block }} & \multirow{2}{*}{\multicolumn{2}{|c|}{$\mathrm{P} \%$}} & \multirow[b]{2}{*}{${ }^{207} \mathrm{~Pb} /{ }^{235} \mathrm{U}$} & \multicolumn{2}{|c|}{ Isotope ratios } & \multirow[b]{2}{*}{$2 \sigma, \%$} & \multirow[b]{2}{*}{ Rho } & \multirow[b]{2}{*}{${ }^{206} \mathrm{~Pb} /{ }^{238} \mathrm{U}$} & \multicolumn{2}{|c|}{ Apparent ages } & \multirow[b]{2}{*}{$2 \sigma, \mathrm{Ma}$} & \multirow[b]{2}{*}{$\mathbf{R}$} & \multirow[b]{2}{*}{$\mathbf{S}$} & \multirow[b]{2}{*}{$A / I n$} & \multirow[b]{2}{*}{ C } \\
\hline & & & & & & $2 \sigma, \%$ & ${ }^{206} \mathrm{~Pb} /{ }^{238} \mathrm{U}$ & & & & $2 \sigma, \mathrm{Ma}$ & ${ }^{207} \mathrm{~Pb} /{ }^{235} \mathrm{U}$ & & & & & \\
\hline SG 068-cr9 & EB & $\mathrm{ma04c}$ & 13 & & 0.0929 & 7.70 & 0.0124 & 1.99 & $0.26 i$ & 79.6 & 1.6 & 90.16 & $6.9 i$ & 314 & 43.0 & 1.08 & \\
\hline SG 069-cr1 & EB & jn08a & 13 & 8.6 & 0.3464 & 12.60 & 0.0121 & 6.47 & $0.51 i$ & 71.0 & 4.6 & 279.30 & $35.2 !$ & 137 & 17.0 & 1.14 & \\
\hline SG 069-cr13 & EB & jn08b & 5 & & 0.2718 & 3.97 & 0.0375 & 1.37 & $0.35 i$ & 237.3 & 3.3 & 244.16 & $9.7 !$ & 380 & 47.1 & 1.03 & * \\
\hline SG 069-cr14 & EB & jn08b & 6 & 2.5 & 0.3568 & 10.32 & 0.0392 & 2.45 & $0.24 !$ & 241.6 & 5.9 & 303.06 & $31.3 !$ & 90 & 11.2 & 1.19 & \\
\hline SG 069-cr16 & EB & jn08b & 7 & & 0.0549 & 3.72 & 0.0084 & 1.28 & 0.34 & 53.7 & 0.7 & 54.26 & $2.0 !$ & 384 & 47.6 & 1.00 & * \\
\hline SG 069-cr17-r & EB & jn08b & 8 & & 0.3777 & 3.46 & 0.0486 & 1.35 & $0.39 !$ & 305.8 & 4.1 & 325.38 & 11.3 & 370 & 45.9 & 0.99 & \\
\hline SG 069-cr2 & EB & jn08a & 14 & 6.0 & 0.9233 & 15.58 & 0.0757 & 3.77 & $0.24 !$ & 443.3 & 16.7 & 634.38 & $98.8 !$ & 181 & 22.4 & 1.04 & \\
\hline SG 069-cr5 & EB & jn08a & 16 & 2.0 & 0.4068 & 14.35 & 0.0536 & 3.52 & 0.25 & 329.9 & 11.6 & 340.74 & $48.9 !$ & 60 & 7.4 & 1.05 & * \\
\hline SG 069-cr6 & EB & jn08a & 17 & & 0.3201 & 3.94 & 0.0434 & 1.59 & $0.40 !$ & 273.8 & 4.4 & 281.98 & 11.1 & 430 & 53.3 & 0.96 & * \\
\hline SG 069-cr7 & EB & jn08b & 4 & & 0.3644 & 4.45 & 0.0489 & 1.45 & 0.33 & 307.5 & 4.5 & 315.47 & $14.0 !$ & 248 & 30.8 & 1.00 & * \\
\hline SG 085-cr1 & NB & jn15b & 11 & 5.5 & 0.4607 & 10.80 & 0.0449 & 2.54 & 0.24 & 267.9 & 6.8 & 366.94 & 39.6 & 226 & 28.0 & 1.19 & \\
\hline SG 085-cr2 & NB & jn15b & 12 & 9.8 & 0.5648 & 7.15 & 0.0223 & 3.59 & $0.50 !$ & 128.2 & 4.6 & 417.88 & $29.9 !$ & 120 & 14.9 & 1.09 & \\
\hline SG 085-cr4 & NB & jn15b & 13 & 10.4 & 1.6583 & 7.08 & 0.0815 & 1.88 & 0.27 & 454.7 & 8.6 & 924.85 & 65.4 & 334 & 41.4 & 0.96 & \\
\hline SG 094-9 & NB & jn15b & 15 & & 0.4216 & 16.09 & 0.0516 & 3.65 & $0.23 !$ & 324.4 & 11.8 & 357.22 & 57.5 & 146 & 18.1 & 1.22 & * \\
\hline AvQ 046-cr5-c & Str & $\operatorname{ar01c}$ & 7 & & 0.1255 & 22.27 & 0.0203 & 4.61 & $0.21 !$ & 114.5 & 5.3 & 106.88 & $23.8 !$ & 132 & 18.1 & 0.97 & * \\
\hline AvQ 046-cr7-c & Str & $\operatorname{ar01c}$ & 10 & 2.4 & 0.1158 & 14.83 & 0.0157 & 4.10 & $0.28 !$ & 100.6 & 4.1 & 111.28 & 16.5 & 67 & 9.2 & 1.02 & * \\
\hline AvQ 046-cr7-r & Str & $\operatorname{ar01c}$ & 11 & 2.7 & 0.0231 & 93.10 & 0.0086 & 6.90 & $0.07 !$ & 55.4 & 3.8 & 23.16 & $21.6 !$ & 80 & 11.0 & 1.58 & \\
\hline AvQ 046-cr8-r & Str & $\operatorname{ar01c}$ & 9 & & 1.1952 & 8.58 & 0.0894 & 2.64 & $0.31 !$ & 551.8 & 14.6 & 798.35 & 68.5 & 117 & 16.0 & 1.06 & \\
\hline AvQ 046-cr9-c & Str & $\operatorname{ar01c}$ & 12 & & 0.1284 & 16.83 & 0.0116 & 5.35 & $0.32 !$ & 74.2 & 4.0 & 122.69 & $20.6 !$ & 89 & 12.2 & 1.13 & \\
\hline AvQ 048-cr10r & Str & $\operatorname{ar01d}$ & 13 & & 0.1179 & 16.45 & 0.0164 & 3.66 & 0.22 & 104.8 & 3.8 & 113.14 & $18.6 !$ & 97 & 13.3 & 1.01 & * \\
\hline AvQ 048-cr2-c & Str & $\operatorname{ar01c}$ & 13 & & 0.05958 & 157.22 & 0.0208 & 6.88 & 0.04 & 132.9 & 9.1 & 58.8 & 92.4 & 237 & 33 & 1.17 & * \\
\hline AvQ 048-cr2-r & Str & $\operatorname{ar01c}$ & 14 & & 0.0842 & 8.20 & 0.0127 & 2.33 & $0.28 !$ & 81.5 & 1.9 & 82.07 & $6.7 !$ & 387 & 53.0 & 1.17 & * \\
\hline AvQ 048-cr3-r & Str & $\operatorname{ar01c}$ & 15 & 16.9 & 0.1098 & 11.40 & 0.0106 & 4.54 & $0.40 !$ & 68.0 & 3.1 & 105.78 & 12.1 & 239 & 32.7 & 1.17 & \\
\hline AvQ 048-cr4-c & Str & $\operatorname{ar01c}$ & 17 & 8.0 & 0.0981 & 18.70 & 0.0130 & 4.03 & 0.22 & 76.4 & 3.1 & 87.67 & $16.4 !$ & 336 & 46.0 & 1.29 & * \\
\hline AvQ 048-cr4-r & Str & $\operatorname{ar01c}$ & 16 & & 0.0983 & 12.14 & 0.0118 & 3.13 & $0.26 !$ & 76.7 & 2.4 & 96.56 & 11.7 & 157 & 21.5 & 1.14 & \\
\hline AvQ 048-cr5-c & Str & $\operatorname{ar01d}$ & 4 & & 0.0893 & 10.16 & 0.0132 & 2.36 & 0.23 & 84.5 & 2.0 & 86.87 & $8.8 !$ & 169 & 23.2 & 1.19 & * \\
\hline AvQ 048-cr5-r & Str & $\operatorname{ar01d}$ & 5 & 3.2 & 0.1042 & 10.44 & 0.0129 & 2.85 & $0.27 !$ & 80.1 & 2.3 & 97.57 & 10.2! & 128 & 17.5 & 1.07 & \\
\hline AvQ 048-cr6-c & Str & $\operatorname{ar01d}$ & 6 & & 0.2301 & 14.24 & 0.0345 & 3.19 & $0.22 i$ & 218.7 & 7.0 & 210.31 & $30.0 !$ & 53 & 7.3 & 1.09 & * \\
\hline AvQ 048-cr6-r & Str & $\operatorname{ar01d}$ & 7 & & 0.0946 & 9.24 & 0.0122 & 2.53 & 0.27 & 78.1 & 2.0 & 91.79 & $8.5 !$ & 111 & 15.2 & 1.15 & \\
\hline AvQ 048-cr7-c & Str & $\operatorname{ar01d}$ & 8 & & 0.3378 & 17.38 & 0.0442 & 5.51 & 0.32 & 278.6 & 15.3 & 295.53 & $51.4 !$ & 32 & 4.4 & 1.12 & * \\
\hline AvQ 048-cr7-r & Str & $\operatorname{ar01d}$ & 9 & & 0.0701 & 10.31 & 0.0128 & 2.12 & $0.21 !$ & 81.8 & 1.7 & 68.81 & $7.1 i^{\prime}$ & 77 & 10.5 & 1.05 & \\
\hline AvQ 048-cr8-c & Str & $\operatorname{ar01d}$ & 10 & & 0.0940 & 21.58 & 0.0125 & 5.19 & 0.24 & 79.9 & 4.1 & 91.25 & 19.7 & 329 & 45.1 & 1.37 & * \\
\hline AvQ 048-cr8-r & Str & $\operatorname{ar01d}$ & 11 & & 0.0812 & 14.37 & 0.0115 & 4.25 & $0.30 !$ & 73.7 & 3.1 & 79.32 & $11.4 !$ & 60 & 8.2 & 1.12 & * \\
\hline AvQ 048-cr9-r & Str & $\operatorname{ar01d}$ & 12 & 18.2 & 0.1063 & 14.78 & 0.0140 & 5.03 & 0.34 & 73.6 & 3.7 & 84.72 & 12.5 & 221 & 30.3 & 1.15 & * \\
\hline AvQ 050-cr10 & Str & ja21f & 14 & & 0.1470 & 26.53 & 0.0119 & 7.30 & $0.28 i$ & 76.1 & 5.6 & 139.28 & $36.9 !$ & 77 & 9.5 & 1.18 & \\
\hline AvQ 050-cr10r & Str & ja21f & 13 & & 0.1037 & 48.04 & 0.0134 & 10.39 & 0.22 & 85.7 & 8.9 & 100.21 & 48.1' & 78 & 9.7 & 1.07 & * \\
\hline AvQ 050-cr3-c & Str & ja21f & 16 & & 0.0894 & 22.35 & 0.0124 & 5.12 & $0.23 !$ & 79.2 & 4.1 & 86.99 & $19.4 !$ & 248 & 30.8 & 1.19 & * \\
\hline AvQ 050-cr4-c & Str & ja21f & 17 & 1.9 & 0.1318 & 19.29 & 0.0123 & 7.32 & 0.38 & 78.6 & 5.8 & 125.74 & 24.3 & 204 & 25.3 & 1.24 & \\
\hline AvQ 050-cr5-c & Str & ja21f & 15 & 15.9 & 0.0998 & 15.82 & 0.0107 & 5.30 & $0.34 !$ & 68.4 & 3.6 & 96.55 & $15.3 !$ & 272 & 33.7 & 1.21 & \\
\hline
\end{tabular}


Appendix 2.

\begin{tabular}{|c|c|c|c|c|c|c|c|c|c|c|c|c|c|c|c|c|c|}
\hline \multirow{2}{*}{$\begin{array}{l}\text { sample \# } \\
\text { crystal \# }\end{array}$} & \multirow{2}{*}{\multicolumn{2}{|c|}{ Region block }} & \multirow{2}{*}{\multicolumn{2}{|c|}{$\mathrm{P} \%$}} & \multirow[b]{2}{*}{${ }^{207} \mathrm{~Pb} /{ }^{235} \mathrm{U}$} & \multicolumn{2}{|c|}{ Isotope ratios } & \multirow[b]{2}{*}{$2 \sigma, \%$} & \multirow[b]{2}{*}{ Rho } & \multirow[b]{2}{*}{${ }^{206} \mathrm{~Pb} / 238 \mathrm{U}$} & \multicolumn{2}{|c|}{ Apparent ages } & \multirow[b]{2}{*}{$2 \sigma, \mathrm{Ma}$} & \multirow[b]{2}{*}{$\mathbf{R}$} & \multirow[b]{2}{*}{$\mathbf{S}$} & \multirow[b]{2}{*}{$\mathrm{A} / \mathrm{ln}$} & \multirow[b]{2}{*}{ C } \\
\hline & & & & & & $2 \sigma, \%$ & ${ }^{206} \mathrm{~Pb} /{ }^{238} \mathrm{U}$ & & & & $2 \sigma, \mathrm{Ma}$ & ${ }^{207} \mathrm{~Pb} /{ }^{235} \mathrm{U}$ & & & & & \\
\hline AvQ 050-cr8-c & Str & ja21f & & 34.4 & 0.0745 & 183.63 & 092 & 7.39 & $0.04 i$ & 59.0 & 4.4 & 72.95 & 134. & 231 & 28.6 & 1.01 & \\
\hline AvQ 050-cr8-r & Str & ja21f & 102 & 27.0 & 0.0980 & 28.05 & 0.0094 & 6.55 & 0.23 & 60.3 & 4.0 & 94.97 & 26.6 & 194 & 24.1 & 1.16 & \\
\hline AvQ 050-cr9-c & Str & ja21f & 11 & & 0.0430 & 97.00 & 0.0137 & 7.29 & 0.08 & 87.5 & 6.4 & 42.75 & 41.5 & 218 & 27.0 & 1.21 & \\
\hline AvQ 050-cr9-r & Str & ja21f & 12 & & 0.0809 & 36.43 & 0.0146 & 6.06 & 0.17 & 93.5 & 5.7 & 78.98 & 28.8 & 152 & 18.8 & 0.97 & \\
\hline AvQ 051-cr10 & Str & ja21g & 4 & & 0.1961 & 46.41 & 0.0429 & 5.88 & 0.13 & 270.7 & 15.9 & 181.84 & $84.4 !$ & 60 & 7.4 & 1.14 & \\
\hline AvQ 051-cr10 & Str & ja21g & 5 & 5.0 & 0.4341 & 25.68 & 0.0534 & 4.77 & $0.19 !$ & 319.1 & 15.2 & 350.49 & 90.0 & 302 & 37.4 & 1.15 & \\
\hline AvQ 051-cr1-c & Str & ja21g & 7 & 8.3 & 0.0812 & 32.36 & 0.0132 & 5.98 & 0.18 & 77.4 & 4.6 & 72.89 & 23.6 & 178 & 22.1 & 1.13 & \\
\hline AvQ 051-cr1-r & Str & ja21g & 8 & & 0.1026 & 19.02 & 0.0127 & 5.07 & 0.27 & 81.1 & 4.1 & 99.14 & $18 . \subseteq$ & 133 & 16.5 & 1.13 & \\
\hline AvQ 051-cr5 & Str & ja21g & 9 & 3.2 & 0.0426 & 81.06 & 0.0155 & 5.72 & 0.07 & 96.0 & 5.5 & 41.06 & 33.3 & 129 & 16.0 & 0.93 & \\
\hline AvQ 051-cr8-r & Str & ja21g & 6 & 2.8 & 0.0928 & 11.87 & 0.0130 & 2.68 & $0.23 !$ & 83.1 & 2.2 & 90.14 & 10.7 & 203 & 25.2 & 1.10 & \\
\hline SG 001-cr11 & Str & jn07a & 11 & 8.5 & 0.2009 & 6.06 & & 2.10 & 0.35 & 84.6 & 1.8 & 185.93 & 11.3 & 315 & 39.1 & 1.00 & \\
\hline SG 001-12-c? & Str & jn07a & 12 & 7.6 & 0.0606 & 22.80 & 0.0104 & 3.54 & 0.16 & 66.9 & 2.4 & 59.75 & $13.6 !$ & 419 & 52.0 & 1.07 & \\
\hline SG 001-12-r & Str & jn07a & 13 & & 0.0833 & 8.74 & 0.0126 & 2.16 & 0.25 & 80.9 & 1.7 & 81.27 & 7.1 & 290 & 36.0 & 1.02 & \\
\hline $1-1-c$ & Str & jn07a & 4 & 2.0 & 0.0630 & 22.74 & 0.0130 & 3.16 & 0.14 & 81.8 & 2.6 & 60.87 & 13.8 & 458 & 56.8 & 0.96 & \\
\hline $1-1-r$ & Str & jn07a & 5 & & & 10.41 & & & & & 2.3 & & $8.2 !$ & 315 & 39.1 & 1.06 & \\
\hline$-5-r$ & Str & jn07a & 6 & & 77 & 9.86 & 132 & 2.16 & 0.22 & 85.7 & 1.9 & & 8.5 & 231 & 28.6 & 1.03 & \\
\hline SG 001-6-c? & Str & jn07a & 7 & & 0.0750 & 14.95 & 125 & 2.43 & 0.16 & 80.3 & 2.0 & 73.40 & 11.0 & 420 & 52.1 & 1.03 & \\
\hline $1-7-r$ & Str & jn07a & 8 & .4 & & 15.64 & 123 & 4.05 & $0.26 !$ & 77.2 & 3.1 & 105.23 & 16.5 & 229 & 28.4 & 1.18 & \\
\hline 1-cr8 & Str & jn07a & 9 & & & & & & & & 2.1 & & $8.6 !$ & 176 & 21.8 & 0.98 & \\
\hline$-\operatorname{cr} 9$ & Str & jn07a & 10 & 1.9 & & 5.38 & & & & & 1.8 & & $8.4 !$ & 360 & 44.6 & 1.02 & \\
\hline SG 011-cr1 & Str & ja12b & 4 & & 0.0958 & 7.76 & 129 & 1.78 & 0.23 & 82.8 & 1.5 & 92.92 & 7.2 & 76 & 10.2 & 1.10 & \\
\hline SG 011-cr10 & Str & ja12b & 14 & & 85 & 10.88 & 122 & 3.18 & $0.29 !$ & 78.3 & 2.5 & 39 & 10.4 & 158 & 21.2 & 1.14 & \\
\hline SG 011-cr11 & Str & ja12b & 15 & & & & & & $0.25 !$ & & 2.1 & & 8.5 & 394 & 52.8 & 1.03 & \\
\hline 1-cr12 & Str & & 16 & & & & & & & & 1.6 & & $61^{\prime}$ & 125 & 16.8 & 1.10 & \\
\hline SG 011-cr2 & Str & ja12b & 5 & & 80 & 8.68 & 135 & 2.43 & 0.28 & 86.5 & 2.1 & 94.90 & 8.2 & 122 & 16.3 & 1.05 & \\
\hline SG 011-cr3 & Str & ja12b & 6 & & 99 & 11.53 & 136 & 2.72 & $0.24 !$ & 86.9 & 2.4 & 87.45 & 10.1! & 116 & 15.5 & 1.05 & \\
\hline SG 011-cr4 & Str & ja12b & 7 & & & 13.12 & 0.0124 & 2.85 & $0.22 !$ & 79.2 & 2.3 & 74.83 & $9.8 !$ & 79 & 10.6 & 1.11 & \\
\hline 011-cr5 & Str & & 8 & & & & & 1.76 & 0.28 & & 1.7 & & 5.9 & 114 & 15.3 & 1.02 & \\
\hline SG 011-cr6 & Str & ja12b & 9 & & & 8.34 & 132 & 2.42 & & 84.4 & 2.0 & 98 & 7.7 & 201 & 26.9 & 1.03 & \\
\hline SG 011-cr7 & Str & ja12b & 10 & 2.1 & 0.0 & 8.08 & 140 & 2.41 & 0.30 & 87.9 & 2.1 & 91.09 & $7.4 !$ & 313 & 41.9 & 1.07 & \\
\hline SG 011-cr7 & Str & ja12b & 11 & 9.1 & 0.0774 & 20.73 & 0.0118 & 4.27 & 0.21 & 75.4 & 3.2 & 75.66 & 15.7 & 311 & 41.7 & 1.18 & \\
\hline SG 011-cr8 & Str & ja12b & 12 & & & 11.89 & 0.0137 & 3.27 & $0.27 !$ & 87.8 & 2.9 & 84.27 & 10.0 & 36 & 4.8 & 1.00 & \\
\hline SG 011-cr9 & Str & ja12b & 13 & 3.0 & 0.1215 & 12.25 & 0.0148 & 3.65 & & 91.6 & 3.3 & 113.19 & 13.9 & 198 & 26.5 & 1.15 & \\
\hline SG 021-cr1 & Str & jn15a & 12 & & 0.0753 & 5.86 & 0.0124 & 1.31 & 0.22 & 79.4 & 1.0 & 73.68 & $4.3 !$ & 364 & 45.1 & 1.04 & \\
\hline SG 021-11 & Str & jn15a & 15 & & 0.0754 & 8.60 & 0.0121 & 1.88 & 0.22 & 77.5 & 1.5 & 73.80 & 6.3 & 97 & 12.0 & 1.05 & \\
\hline SG 021-12 & Str & jn15a & 16 & & 0.0858 & 6.89 & 0.0113 & 1.63 & 0.24 & 72.7 & 1.2 & 83.62 & $5.8 !$ & 343 & 42.5 & 1.07 & \\
\hline SG 021-2-r & Str & jn15a & 13 & & 0.0684 & 7.89 & 0.0103 & 1.76 & 0.22 & 66.0 & 1.2 & 67.14 & 5.3 & 224 & 27.8 & 1.09 & \\
\hline SG 021-cr8 & Str & jn15a & 14 & & 0.0853 & 6.43 & 0.0122 & 1.52 & 0.24 & 77.8 & 1.2 & 82.65 & 5.3! & 336 & 41.7 & 1.05 & \\
\hline SG 028-cr1-c & Str & ma04c & 14 & 5.0 & 0.2989 & 13.91 & 0.0418 & 3.71 & 0.27 & 250.8 & 9.3 & 253.83 & 35.3 & 113 & 15.5 & 1.22 & \\
\hline SG 028-cr1-r & Str & $\mathrm{ma04c}$ & 14 & & 0.1402 & 18.44 & 0.0127 & 7.33 & 0.40 & 81.5 & 6.0 & 133.22 & $24.6 !$ & 68 & 9.3 & 1.07 & \\
\hline
\end{tabular}


Appendix 2.

\begin{tabular}{|c|c|c|c|c|c|c|c|c|c|c|c|c|c|c|c|c|c|}
\hline \multirow{2}{*}{$\begin{array}{l}\text { sample \# } \\
\text { crystal \# }\end{array}$} & \multirow{2}{*}{\multicolumn{2}{|c|}{ Region block }} & \multirow{2}{*}{\multicolumn{2}{|c|}{$\mathrm{P} \%$}} & \multirow[b]{2}{*}{${ }^{207} \mathrm{~Pb} /{ }^{235} \mathrm{U}$} & \multicolumn{2}{|c|}{ Isotope ratios } & \multirow[b]{2}{*}{$2 \sigma, \%$} & \multirow[b]{2}{*}{ Rho } & \multirow[b]{2}{*}{${ }^{206} \mathrm{~Pb} /{ }^{238} \mathrm{U}$} & \multicolumn{2}{|c|}{ Apparent ages } & \multirow[b]{2}{*}{$2 \sigma, \mathrm{Ma}$} & \multirow[b]{2}{*}{$\mathbf{R}$} & \multirow[b]{2}{*}{$\mathbf{S}$} & \multirow[b]{2}{*}{$A / \ln$} & \multirow[b]{2}{*}{ C } \\
\hline & & & & & & $2 \sigma, \%$ & ${ }^{206} \mathrm{~Pb} /{ }^{238} \mathrm{U}$ & & & & $2 \sigma, \mathrm{Ma}$ & ${ }^{07} \mathrm{~Pb} /{ }^{235} \mathrm{U}$ & & & & & \\
\hline SG 028-cr2-c & Str & $\mathrm{ma04c}$ & 17 & 7.4 & 0.1082 & 38.32 & & 7.10 & $0.19 i$ & 76.7 & 5.4 & 96.91 & 37.1 & 167 & 22.9 & 1.14 & \\
\hline SG 028-cr2-r & Str & $\mathrm{ma04c}$ & 16 & & 0.1077 & 21.11 & 0.0131 & 5.74 & $0.27 !$ & 79.4 & 4.6 & 98.72 & $20.8 i$ & 251 & 34.4 & 1.23 & \\
\hline SG 028-cr3-c & Str & $\mathrm{ma04d}$ & 4 & & 0.3500 & 18.21 & 0.0467 & 3.91 & $0.21 !$ & 296.1 & 11.6 & 306.19 & $55.8 i$ & 156 & 21.4 & 1.28 & \\
\hline SG 028-cr3-r & Str & $\mathrm{ma04d}$ & 5 & & 0.0758 & 15.12 & 0.0127 & 2.76 & 0.18 & 81.8 & 2.3 & 74.71 & 11.3 & 242 & 33.2 & 1.08 & \\
\hline SG 028-cr4 & Str & $\mathrm{ma04d}$ & 6 & 5.1 & 0.0984 & 10.51 & 0.0117 & 3.91 & $0.37 !$ & 74.7 & 2.9 & 95.34 & $10.0 !$ & 164 & 22.5 & 1.09 & \\
\hline SG 028-cr4-c? & Str & $\mathrm{ma04d}$ & 7 & & 0.3345 & 13.66 & 0.0358 & 5.26 & 0.39 & 225.4 & 11.9 & 291.64 & 39.8 & 86 & 11.8 & 1.10 & \\
\hline SG 028-cr5 & Str & ma04d & 8 & & 0.0833 & 7.52 & 123 & & $0.25 !$ & 78.0 & 1.5 & 80.25 & $6.0 !$ & 503 & 68.9 & 1.09 & \\
\hline SG 028-cr6 & Str & $\mathrm{ma04d}$ & 9 & 8.5 & 0.1185 & 26.05 & 0.0119 & 6.43 & 0.25 & 76.3 & 4.9 & 113.74 & 29.6 & 266 & 36.4 & 1.26 & \\
\hline SG 028-cr6-r & Str & $\mathrm{ma04d}$ & 10 & & 0.0826 & 10.68 & 0.0116 & 3.14 & $0.29 !$ & 74.4 & 2.3 & 80.61 & $8.6 !$ & 156 & 21.4 & 1.13 & \\
\hline SG 028-cr7 & Str & $\mathrm{ma04d}$ & 11 & & 0.0915 & 6.81 & 0.0123 & 2.05 & 0.30 & 79.3 & 1.6 & & $6.1 i$ & 444 & 60.8 & 1.03 & \\
\hline $028-c r 8$ & Str & $\mathrm{ma04d}$ & 13 & 8.9 & & & & 2.66 & $0.23 !$ & 71.9 & 1.9 & & $8.9 !$ & 325 & 4.5 & 1.13 & \\
\hline SG 028-cr8-c & Str & ma04d & 12 & 1.9 & 0.0853 & 14.54 & 124 & 3.30 & 0.23 & 79.3 & 2.6 & 83.12 & 12.1 & 280 & 38.4 & 1.07 & \\
\hline SG 028-cr-r & Str & $\mathrm{ma04c}$ & 15 & & 0.0978 & 6.82 & 0.0151 & 1.73 & $0.25 !$ & 94.1 & 1.6 & 92.32 & $6.3 !$ & 195 & 26.7 & 0.91 & \\
\hline SG 051-cr1 & Str & ja12c & & 16.5 & 1.6938 & 5.32 & 0.0416 & 6.95 & $0.99 !$ & 220.2 & 15.3 & 894.73 & $47.6 !$ & 247 & 33.1 & 1.39 & \\
\hline 1-cr10 & Str & ja12c & 17 & & & & & & $0.61 !$ & & 5.6 & & $13.3 !$ & 456 & & 1.03 & \\
\hline SG 051-cr11-c & Str & ja12d & 4 & & & 12.80 & & 5.63 & $0.44 !$ & 85.2 & 4.8 & & $10.6 !$ & 375 & 0.3 & 1.03 & \\
\hline SG 051-cr1 & Str & ja12c & 4 & & 0.6230 & 7.41 & 543 & 9.98 & $0.99 !$ & 340.9 & 34.0 & 491.74 & $36.4 !$ & 101 & 13.5 & 1.28 & \\
\hline -cr1-r & Str & $\mathrm{ja} 12 \mathrm{~b}$ & 17 & 7.2 & & 59.14 & 285 & 7.09 & $0.12 !$ & 168.5 & 11.9 & .77 & $60.8 !$ & 220 & 29.5 & 1.17 & \\
\hline & Str & & 7 & 2.3 & & & & & & & 4.7 & & $.1 !$ & 186 & 24.9 & 0.99 & \\
\hline 1-cr2-r & Str & ja12c & & 74.6 & & & & & $0.83 !$ & & 9.7 & & $93.0 !$ & 240 & 32.2 & 1.10 & \\
\hline 51-cr3-c & itr & ja12c & 8 & 7.0 & 69 & 6.25 & 240 & 5.31 & 0.85 & 2.6 & 7.6 & 56 & $21.2 !$ & 208 & 27.9 & 0.83 & \\
\hline 1-cr3-r & Str & ja12c & & 19.0 & & 15.00 & 05 & 13.08 & 0.87 & 67.1 & 8.8 & & 39.9 & 33 & 4.4 & 1.19 & \\
\hline & Str & & 10 & 4.1 & & & & & & & 4.0 & & $.1 !$ & 85 & 1.4 & 0.94 & \\
\hline -cr5-c & Str & & 12 & 2.0 & & & & & & & & & 20.5 & 418 & 6.0 & 1.17 & \\
\hline I-cr5-r & tr & ja12c & 11 & & & 10.76 & 24 & 6.61 & $0.61 !$ & 9.3 & 21.8 & & 40.2 & 175 & 3.5 & 1.32 & \\
\hline SG 051-cr6-c & Str & ja12c & 13 & 10.4 & & & 61 & 10.46 & $0.66 !$ & & 21.5 & & $65.4 !$ & 103 & 13.8 & 1.22 & \\
\hline SG 051-cr7-c & Str & & & 56.4 & & & & & & & 9.2 & & & 100 & 3.4 & 1.04 & \\
\hline $1-c r 8$ & Str & ja12c & & 12.7 & & & & & & & 7.5 & & $52.2 !$ & 394 & 52.8 & 0.91 & \\
\hline SG 051-cr9-r & Str & ja12c & 16 & 66.8 & & & & & & 75.2 & 1.9 & & $22.6 !$ & 292 & 39.1 & 1.07 & \\
\hline $2-1-c$ & Str & jn08d & 12 & & 25 & 7.66 & & 3.45 & $0.45 !$ & 98.3 & 3.4 & & $6.9 i^{i}$ & 370 & 45.9 & 0.95 & \\
\hline & Str & & 132 & 26.5 & & 17.28 & & & & 59.8 & 3.4 & & $28.0 !$ & 386 & 47.9 & 1.31 & \\
\hline$-c r 3$ & Str & & 14 & 9.1 & & & & & & 78.6 & 4.1 & & $22.5 !$ & 245 & 30.4 & 1.15 & \\
\hline SG 052-5-c & & jn08d & 17 & 10.4 & & 47.01 & & & & 79.6 & 4.9 & & $30.7 !$ & 290 & 36.0 & 1.11 & \\
\hline SG 052-6-c & Str & jn08d & 16 & 1.9 & & 12.64 & 37 & 3.89 & $0.31 i$ & 330.8 & 12.9 & & $40.0 !$ & 343 & 42.5 & 1.04 & \\
\hline SG 052-cr7 & Str & jn08d & 15 & 2.1 & & 58.65 & & & & 77.9 & 4.0 & & $19.1 !$ & 268 & 33.2 & 1.17 & \\
\hline SG $053-10-c$ & Str & & 9 & 12.9 & & 7.66 & 143 & 4.14 & & 79.9 & 3.3 & & $24.4 !$ & 260 & 32.2 & 1.13 & \\
\hline SG 053-11 & Str & & 10 & & & 11.14 & 0.0114 & & 0.27 & 70.5 & 2.1 & 93.60 & 10.4 & 200 & 24.8 & 1.02 & \\
\hline SG 053-1-c? & Str & jn15b & 4 & & & 12.12 & 0.0439 & 3.11 & $0.26 !$ & 275.8 & 8.6 & 352.74 & $42.8 !$ & 190 & 23.6 & 1.11 & \\
\hline SG 053-cr2 & Str & jn15b & 5 & & 0.0859 & 26.28 & 0.0112 & 4.81 & 0.18 & 71.1 & 3.4 & 82.78 & 21.8 & 151 & 18.7 & 1.31 & \\
\hline SG 053-3-c & Str & jn15b & 6 & 3.5 & 0.1610 & 6.83 & 0.0195 & 1.75 & $0.26 !$ & 120.0 & 2.1 & 146.68 & $10.0 !$ & 237 & 29.2 & 1.21 & \\
\hline
\end{tabular}


Appendix 2.

\begin{tabular}{|c|c|c|c|c|c|c|c|c|c|c|c|c|c|c|c|c|c|}
\hline & & & & & & & & & & & & & & & & & \\
\hline & gi & ock & & $\mathbf{P} \%$ & ${ }^{35} \mathrm{U}$ & $2 \sigma, \%$ & & $\sigma, \%$ & ho & 60 & in & & $\sigma, \mathrm{Ma}$ & $\mathbf{R}$ & $\mathbf{S}$ & $\mathrm{A} / \mathrm{ln}$ & C \\
\hline SG 053-cr5 & Str & jn15a & 17 & & 0.5320 & 9.47 & 0623 & .22 & $0.23 i$ & 393.5 & 8.7 & 37.06 & $41.4 i$ & 115 & 14.3 & 1.09 & \\
\hline SG 053-cr7-c & Str & jn15b & 7 & & & 17.55 & & 3.77 & $0.22 i$ & & 3.1 & & 16.7 & 154 & 19.1 & 1.19 & * \\
\hline SG 053-cr9 & Str & jn15b & 8 & & & 10.59 & & 3.49 & $0.33 i$ & 76.8 & 2.7 & & $12.0 !$ & 235 & 29.1 & 1.21 & \\
\hline SG 057-cr1-r? & Str & ma04e & 11 & & 0.3580 & 9.05 & & 2.28 & $0.25 i$ & 278.1 & 6.3 & & $28.3 !$ & 458 & 62.7 & 1.13 & \\
\hline G 057-cr2-r & Str & ma04e & 12 & 7.4 & 0.2102 & 6.06 & & 1.69 & $0.28 i$ & & 2.2 & & 11.7 & 356 & 48.8 & 0.98 & \\
\hline SG 057-cr2-r & Str & $\mathrm{ma04e}$ & 13 & & & 8.17 & & 2.40 & $0.29 i$ & & 3.5 & & & 176 & 24.1 & 1.02 & 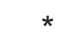 \\
\hline G 057-cr3 & Str & ma04e & 10 & 2.2 & 0.2923 & 6.26 & & 1.85 & $0.30 i$ & & 4. & & $16.0 !$ & 288 & 39.5 & 0.99 & \\
\hline 7-cr4 & Str & ma04e & 14 & & & 3.40 & & 1.30 & & & 5.9 & & 16.4 & 347 & 47.5 & 1.04 & \\
\hline 7-cr5-r & Str & ma04e & 16 & & & 17.27 & & 4.47 & & & & & $7.7 !$ & 78 & 10.7 & 1.21 & \\
\hline$?$ & Str & $\mathrm{ma0}$ & 15 & & & & & 2.25 & & & & & 9.5 & 81 & & 1.13 & * \\
\hline$-r$ & Str & ma04e & 17 & 4.4 & & 19 & & 4.75 & & & & & $27.7 !$ & 304 & 41.6 & 1.21 & * \\
\hline sc & Str & $\mathrm{mac}$ & 6 & 7.1 & & 1 & & 6.51 & & & 15.5 & & & & 0 & 1.21 & \\
\hline SG & Str & ma04f & 5 & & & 1 & & 2.95 & & & & & & & & 1.20 & \\
\hline & & $\mathrm{ma}$ & 4 & & & 17. & & 3. & & & & & & & & 1.01 & * \\
\hline & & jn08c & 10 & & & & & 1.79 & & & & & 6.11 & & & 1.07 & * \\
\hline & & jn08c & 11 & & & & & 1.88 & & & & & $6.9 !$ & & & 98 & * \\
\hline & & jn08c & 12 & & & & & 2. & & & & & $8.9 !$ & & & 44 & * \\
\hline & & jnc & 8 & 2 & & & & & & & & & 7.3i & & & 34 & \\
\hline & 5 & jno & 9 & & & & & 1. & & & & & .81 & & & 4 & * \\
\hline & & & 1 & & & & & & & & & & .4i & & & & \\
\hline & & & 16 & 3.8 & & & & & & & & & $.6 !$ & & & 11 & \\
\hline & & & 7 & & & & & & & & & & $-5.6 !$ & 6 & & 6 & \\
\hline & & & 8 & 3.6 & & & & & & & & & 19.4 & & & 8 & * \\
\hline & & & 10 & & & & & & & & & & $52.0 !$ & & & 17 & \\
\hline & & $\mathrm{ma}$ & 11 & 5.4 & & 2. & & 4. & & & 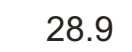 & & $56.7 !$ & 405 & 5 & 1.56 & \\
\hline & & $\mathrm{ma}$ & 12 & & & 19 & & 2. & & & 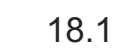 & & $148.2 i$ & $2 \varepsilon$ & 6 & 34 & 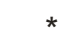 \\
\hline & & ja2 & 14 & 8.5 & & 1 & & 3. & $0.21 i$ & & 14 & & $77.2 i$ & 178 & 22.1 & .16 & * \\
\hline & $\mathrm{v}$ & in & 15 & & & 2 & & 4. & $0.15 i$ & & 19 & & 138.4 & 120 & 14.9 & 1.19 & 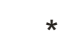 \\
\hline S & & 20? & 13 & 3.2 & & 105.7 & & 3. & $0.03 i$ & & 15.2 & & $20.0 !$ & 264 & 32.7 & 1.18 & \\
\hline & & i2 210 & 11 & & & 9.6 & & 2.2 & $0.23 i$ & & 3 & & 15.8i & 200 & 24.8 & 1.00 & \\
\hline & & i2 210 & 12 & & & 8.2 & & 2. & $0.28 i$ & & & & $3 i$ & & 8.1 & 1.06 & \\
\hline & & i2 $21 \mathrm{a}$ & 10 & 5.6 & & 113 & & 4.9 & 0.34 & & 20.7 & & 00.5 & 71 & 8 & 0.99 & \\
\hline $\mathrm{AvC}$ & & jn15a & 10 & & & & & 3.3 & 0.29 & & 2 & & 9.1 & 328 & 40.7 & 1.07 & \\
\hline & & $5-$ & 7 & & & 18.2 & & 3.2 & 0.18 & & 2. & & 12.4 & 78 & 9.7 & 1.19 & \\
\hline $\mathrm{AvC}$ & & $5-$ & 8 & & & & & 2.2 & $0.23 !$ & & & & 8.0 & 384 & 47.6 & 1.01 & \\
\hline AvQ 0 & & jn15a & 5 & & & 6.2 & & 1. & $0.24 i$ & & & & 5.2 & 373 & 6.3 & 1.00 & \\
\hline AvQ 058-cr1 & YB & jn15a & 4 & & & & & 1.7 & $0.23 i$ & 70.8 & 1.2 & & 5.8 & 438 & 54.3 & 1.06 & \\
\hline$A v Q 05$ & YB & jn15a & 6 & 2.7 & & 21. & & 3.81 & 0 & & 2.2 & & 11.2 & 215 & 26.7 & 1.18 & \\
\hline AvQ 142 & YB & ja21f & 8 & & 0.0897 & 12.64 & 0.0113 & 3.77 & 0.30 & 72.1 & 2.7 & 87.19 & 11.0 & 235 & 29.1 & 1.18 & \\
\hline
\end{tabular}


Appendix 2.

\begin{tabular}{|c|c|c|c|c|c|c|c|c|c|c|c|c|c|c|c|c|c|}
\hline \multirow{2}{*}{$\begin{array}{l}\text { sample \# } \\
\text { crystal \# }\end{array}$} & \multirow{2}{*}{\multicolumn{2}{|c|}{ Region block }} & \multirow{2}{*}{\multicolumn{2}{|c|}{$\mathbf{P} \%$}} & \multirow[b]{2}{*}{${ }^{207} \mathrm{~Pb} /{ }^{235} \mathrm{U}$} & \multicolumn{3}{|c|}{ Isotope ratios } & \multirow[b]{2}{*}{ Rho } & \multirow[b]{2}{*}{${ }^{206} \mathrm{~Pb} /{ }^{238} \mathrm{U}$} & \multicolumn{2}{|c|}{ Apparent ages } & \multirow[b]{2}{*}{$2 \sigma, \mathrm{Ma}$} & \multirow[b]{2}{*}{$\mathbf{R}$} & \multirow[b]{2}{*}{$\mathrm{s}$} & \multirow[b]{2}{*}{$A / \ln$} & \multirow[b]{2}{*}{ C } \\
\hline & & & & & & $2 \sigma, \%$ & ${ }^{206} \mathrm{~Pb} /{ }^{238} \mathrm{U}$ & $2 \sigma, \%$ & & & $2 \sigma, \mathrm{Ma}$ & ${ }^{207} \mathrm{~Pb} /{ }^{235} \mathrm{U}$ & & & & & \\
\hline AvQ 142 & YB & ja21f & & 17.8 & 0.0940 & 10.16 & 0.0124 & 3.73 & $0.37 i$ & 65.4 & 2.4 & 75.56 & $7.7 i$ & 272 & 33.7 & 1.10 & * \\
\hline AvQ 142 & YB & ja21f & 6 & 3.5 & 0.6091 & 16.25 & 0.0768 & 3.53 & $0.22 i$ & 461.2 & 16.3 & 469.60 & $76.3 !$ & 190 & 23.6 & 1.15 & * \\
\hline SG 040-cr1 & YB & jn15c & & 13.5 & 0.1574 & 9.20 & 0.0099 & 3.91 & $0.42 i$ & 55.0 & 2.2 & 129.68 & $11.9 !$ & 80 & 9.9 & 1.21 & \\
\hline SG 040-cr2 & YB & jn15c & & 32.0 & 0.1888 & 15.62 & 0.0088 & 8.01 & $0.51 i$ & 56.4 & 4.5 & 175.63 & $27.4 !$ & 120 & 14.9 & 1.03 & \\
\hline SG 040-cr3 & YB & jn15c & 101 & 10.1 & 0.1696 & 22.47 & 0.0104 & 4.79 & $0.21 !$ & 66.9 & 3.2 & 159.09 & $35.7 !$ & 29 & 3.6 & 1.11 & \\
\hline SG 040-cr4-r & YB & jn15c & 11 & 3.0 & 0.0822 & 26.66 & 0.0124 & 5.87 & $0.22 !$ & 79.3 & 4.7 & 80.20 & $21.4 !$ & 195 & 24.2 & 0.92 & * \\
\hline SG 040-cr5 & YB & jn15c & 12 & & 0.0952 & 13.79 & 0.0122 & 5.82 & $0.42 !$ & 77.3 & 4.5 & 91.20 & $12.6 !$ & 107 & 13.3 & 1.12 & * \\
\hline SG 040-cr6 & YB & jn15c & 13 & 3.0 & 0.1122 & 6.48 & 0.0124 & 2.93 & 0.45 & 79.4 & 2.3 & 108.00 & $7.0 !$ & 446 & 55.3 & 0.95 & \\
\hline SG 040-cr7 & YB & jn15c & 14 & 2.4 & 0.0860 & 7.21 & 0.0119 & 3.49 & $0.48 i$ & 76.1 & 2.7 & 83.76 & $6.0 i$ & 163 & 20.2 & 1.07 & * \\
\hline SG 040-cr8 & YB & jn15c & 15 & & 0.0941 & 3.22 & 0.0130 & 1.67 & $0.52 !$ & 83.5 & 1.4 & 91.32 & $2.9 !$ & 326 & 40.4 & 0.99 & \\
\hline SG 040-cr9 & YB & jn15c & 16 & & 0.1735 & 8.29 & 0.0225 & 3.26 & $0.39 !$ & 143.3 & 4.7 & 162.46 & 13.5 & 450 & 55.8 & 1.23 & \\
\hline SG 041-cr10 & YB & jn07b & 7 & & 0.0904 & 3.19 & 0.0132 & 1.09 & 0.34 & 84.7 & 0.9 & 87.90 & $2.8 !$ & 320 & 39.7 & 1.01 & * \\
\hline SG 041-cr12 & YB & jn07a & 172 & 21.3 & 0.1681 & 6.74 & 0.0106 & 1.78 & $0.26 !$ & 67.8 & 1.2 & 157.75 & 10.6! & 97 & 12.0 & 1.18 & \\
\hline SG 041-cr13 & YB & jn07b & & 13.0 & 0.2826 & 7.00 & 0.0129 & 2.64 & 0.38 & 71.9 & 1.9 & 223.26 & 15.6 & 302 & 37.4 & 1.07 & \\
\hline SG 041-cr3 & YB & jn07b & 4 & 3.1 & 0.1132 & 2.65 & 0.0137 & 0.82 & $0.31 !$ & 85.0 & 0.7 & 105.68 & $2.8 i$ & 383 & 47.5 & 1.01 & \\
\hline SG 041-cr4 & YB & jn07a & 16 & & 0.0953 & 3.62 & 0.0134 & 0.89 & 0.25 & 85.8 & 0.8 & 92.40 & $3.3 !$ & 374 & 46.4 & 1.01 & \\
\hline SG 041-cr6 & YB & jn07b & 5 & & 0.0825 & 3.06 & 0.0126 & 0.86 & $0.28 i$ & 81.0 & 0.7 & 80.46 & 2.5 & 398 & 49.4 & 1.05 & * \\
\hline SG 041-7-r & YB & jn07a & 14 & & 0.0924 & 5.23 & 0.0144 & 1.45 & 0.28 & 91.7 & 1.3 & 89.45 & $4.7 !$ & 275 & 34.1 & 1.00 & * \\
\hline SG 041-8-r & YB & jn07a & 15 & 5.0 & 0.0413 & 20.46 & 0.0115 & 1.70 & $0.08 !$ & 70.0 & 1.2 & 39.11 & $8.0 !$ & 183 & 22.7 & 1.20 & \\
\hline SG 041-cr9 & YB & jn07b & 6 & & 0.0849 & 7.32 & 0.0121 & 1.88 & 0.26 & 78.0 & 1.5 & 82.97 & $6.1 !$ & 56 & 6.9 & 1.06 & * \\
\hline SG 044-cr1 & YB & $\mathrm{ma04d}$ & 14 & & 0.0789 & 9.73 & 0.0123 & 2.26 & $0.23 !$ & 78.7 & 1.8 & 77.14 & $7.5 !$ & 270 & 37.0 & 1.08 & * \\
\hline SG 044-cr10 & YB & ma04e & 9 & & 0.0802 & 4.49 & 0.0125 & 1.29 & $0.29 !$ & 80.0 & 1.0 & 78.33 & 3.5 & 402 & 55.1 & 1.00 & * \\
\hline SG 044-cr2 & YB & ma04d & 15 & & 0.0906 & 5.92 & 0.0130 & 1.71 & $0.29 !$ & 83.2 & 1.4 & 88.03 & $5.2 !$ & 270 & 37.0 & 1.03 & * \\
\hline SG 044-cr3 & YB & $\mathrm{ma04d}$ & 16 & & 0.0733 & 26.79 & 0.0120 & 4.85 & 0.18 & 76.8 & 3.7 & 71.96 & 19.3 & 135 & 18.5 & 1.19 & * \\
\hline SG 044-cr4 & YB & $\mathrm{ma04d}$ & 17 & & 0.0733 & 6.63 & 0.0121 & 1.63 & 0.25 & 77.8 & 1.3 & 72.28 & $4.8 i$ & 235 & 32.2 & 1.11 & * \\
\hline SG 044-cr5 & YB & ma04e & 4 & & 0.0883 & 16.83 & 0.0110 & 4.08 & $0.24 !$ & 70.5 & 2.9 & 85.88 & $14.5 !$ & 61 & 8.4 & 1.06 & * \\
\hline SG 044-cr6 & YB & ma04e & 5 & & 0.0730 & 7.74 & 0.0110 & 2.02 & $0.26 !$ & 70.2 & 1.4 & 71.57 & $5.5 i$ & 57 & 7.8 & 1.10 & * \\
\hline SG 044-cr7 & YB & ma04e & 6 & & 0.0808 & 8.51 & 0.0124 & 1.97 & 0.23 & 79.7 & 1.6 & 79.32 & 6.8 & 149 & 20.4 & 1.03 & * \\
\hline SG 044-cr8 & YB & ma04e & 7 & & 0.0839 & 4.86 & 0.0123 & 1.49 & $0.31 !$ & 78.5 & 1.2 & 81.83 & $4.0 !$ & 208 & 28.5 & 1.04 & * \\
\hline SG 044-cr9-r & YB & $\mathrm{ma04e}$ & 8 & & 0.0883 & 4.00 & 0.0125 & 1.42 & 0.35 & 80.0 & 1.1 & 85.93 & $3.4 !$ & 328 & 44.9 & 1.00 & \\
\hline SG 063-cr10 & YB & jn12a & 17 & & 0.1557 & 7.97 & 0.0194 & 4.00 & $0.50 !$ & 123.6 & 4.9 & 146.91 & $11.7 !$ & 100 & 13.4 & 0.90 & \\
\hline SG 063-cr1 & YB & jn12a & 4 & & 0.0723 & 20.95 & 0.0107 & 5.28 & 0.25 & 68.4 & 3.6 & 70.83 & 14.8 & 118 & 15.8 & 1.20 & * \\
\hline SG 063-cr2-c & YB & jn12a & 6 & & 0.8584 & 30.25 & 0.0344 & 16.61 & 0.55 & 217.9 & 36.2 & 629.24 & $190.4 !$ & 23 & 3.1 & 1.18 & \\
\hline SG 063-cr2-r & YB & jn12a & 5 & & 0.1014 & 13.98 & 0.0112 & 4.76 & $0.34 !$ & 71.6 & 3.4 & 98.07 & $13.7 !$ & 80 & 10.7 & 1.17 & \\
\hline SG 063-cr3 & YB & jn12a & 7 & & 0.6738 & 11.49 & 0.0866 & 3.59 & 0.31 & 537.0 & 19.3 & 524.18 & $60.2 !$ & 110 & 14.7 & 1.04 & * \\
\hline SG 063-cr4 & YB & jn12a & 8 & & 0.2692 & 16.54 & 0.0330 & 4.24 & 0.26 & 209.3 & 8.9 & 242.04 & 40.0 & 70 & 9.4 & 1.15 & * \\
\hline SG 063-cr5 & YB & jn12a & & 17.7 & 0.0668 & 422.57 & 0.0261 & 5.95 & $0.01 !$ & 166.4 & 9.9 & 65.65 & $277.4 !$ & 200 & 26.8 & 0.99 & * \\
\hline SG 063-cr6-c & YB & jn12a & 11 & & 0.5356 & 18.40 & 0.0656 & 4.64 & 0.25 & 410.9 & 19.1 & 436.67 & 80.4 & 67 & 9.0 & 1.09 & * \\
\hline SG 063-cr6-r & YB & jn12a & 10 & & 0.4998 & 29.24 & 0.0553 & 7.76 & $0.27 !$ & 346.9 & 26.9 & 411.54 & $120.3 !$ & 44 & 5.9 & 1.25 & * \\
\hline
\end{tabular}


Appendix 2.

\begin{tabular}{|c|c|c|c|c|c|c|c|c|c|c|c|c|c|c|c|c|c|}
\hline \multirow{2}{*}{$\begin{array}{l}\text { sample \# } \\
\text { crystal \# }\end{array}$} & \multirow{2}{*}{\multicolumn{2}{|c|}{ Region block }} & \multirow{2}{*}{\multicolumn{2}{|c|}{$\mathbf{P} \%$}} & \multirow[b]{2}{*}{${ }^{207} \mathrm{~Pb} /{ }^{235} \mathrm{U}$} & \multicolumn{3}{|c|}{ Isotope ratios } & \multirow[b]{2}{*}{ Rho } & \multirow[b]{2}{*}{${ }^{206} \mathrm{~Pb} /{ }^{238} \mathrm{U}$} & \multicolumn{2}{|c|}{ Apparent ages } & \multirow[b]{2}{*}{$2 \sigma, \mathrm{Ma}$} & \multirow[b]{2}{*}{$\mathbf{R}$} & \multirow[b]{2}{*}{$\mathbf{S}$} & \multirow[b]{2}{*}{$\mathrm{A} / \mathrm{ln}$} & \multirow[b]{2}{*}{$\mathrm{C}$} \\
\hline & & & & & & $2 \sigma, \%$ & ${ }^{206} \mathrm{~Pb} /{ }^{238} \mathrm{U}$ & $2 \sigma, \%$ & & & $2 \sigma, \mathrm{Ma}$ & ${ }^{207} \mathrm{~Pb} /{ }^{235} \mathrm{U}$ & & & & & \\
\hline SG 063-cr7 & YB & jn12a & 12 & & 0.5513 & 17.84 & 0.0808 & 4.38 & $0.25 i$ & 498.8 & 21.9 & 444.19 & $79.2 i$ & 50 & 6.7 & 1.03 & * \\
\hline SG 063-cr8-c & YB & jn12a & 14 & & 0.6075 & 4.73 & 0.0745 & 3.04 & $0.64 i$ & 463.4 & 14.1 & 481.95 & $22.8 i$ & 190 & 25.5 & 1.09 & * \\
\hline SG 063-cr8-r & YB & jn12a & 13 & & 0.3199 & 3.64 & 0.0416 & 2.55 & 0.70 & 262.6 & 6.7 & 281.85 & 10.3! & 325 & 43.6 & 1.09 & \\
\hline SG 063-cr9-c & YB & jn12a & 15 & & 0.3199 & 5.88 & 0.0417 & 2.94 & $0.50 !$ & 264.1 & 7.8 & 282.83 & $16.6 !$ & 245 & 32.8 & 1.06 & * \\
\hline SG 063-cr9-r & YB & jn12a & 16 & & 0.2837 & 4.78 & 0.0316 & 2.73 & 0.57 & 203.5 & 5.5 & 257.01 & 12.3 & 431 & 57.8 & 1.18 & \\
\hline SG 066-cr10 & YB & jn07b & 13 & & 0.2877 & 7.09 & 0.0340 & 2.68 & $0.38 !$ & 216.3 & 5.8 & 257.87 & 18.3! & 188 & 23.3 & 1.01 & \\
\hline SG 066-cr11 & YB & jn07b & 14 & & 0.2256 & 4.80 & 0.0257 & 1.77 & $0.37 !$ & 163.8 & 2.9 & 206.57 & $9.9 !$ & 427 & 52.9 & 1.08 & \\
\hline SG 066-12-c & YB & jn07b & 15 & & 0.1734 & 6.76 & 0.0251 & 2.34 & 0.35 & 158.8 & 3.7 & 161.65 & $10.9 !$ & 136 & 16.9 & 1.14 & * \\
\hline SG 066-12-r & YB & jn07b & 16 & & 0.1377 & 4.11 & 0.0196 & 1.16 & 0.28 & 125.2 & 1.4 & 131.19 & $5.4 !$ & 227 & 28.1 & 1.01 & * \\
\hline SG 066-cr13 & YB & jn07b & 17 & & 0.1504 & 5.48 & 0.0203 & 1.62 & $0.30 !$ & 129.6 & 2.1 & 142.27 & $7.8 !$ & 404 & 50.1 & 0.99 & \\
\hline SG 066-cr6 & YB & jn07b & 9 & & 0.1123 & 8.68 & 0.0157 & 4.13 & 0.48 & 100.3 & 4.1 & 108.21 & 9.4 & 199 & 24.7 & 1.17 & * \\
\hline SG 066-7-c & YB & jn07b & 10 & 6.9 & 0.2248 & 6.16 & 0.0174 & 2.42 & $0.39 !$ & 111.3 & 2.7 & 205.86 & $12.7 !$ & 142 & 17.6 & 1.08 & \\
\hline SG 066-8-r & YB & jn07b & 11 & 3.6 & 0.1376 & 12.37 & 0.0220 & 4.44 & $0.36 !$ & 140.3 & 6.2 & 130.93 & 16.2 & 101 & 12.5 & 1.02 & * \\
\hline SG 066-cr9 & YB & jn07b & 12 & & 0.2573 & 5.34 & 0.0258 & 1.92 & $0.36 !$ & 167.0 & 3.2 & 235.86 & $12.6 !$ & 336 & 41.7 & 1.01 & \\
\hline SG 078-cr1 & YB & jn08b & 9 & 6.7 & 0.1720 & 20.50 & 0.0228 & 4.01 & 0.20 & 135.9 & 5.5 & 151.08 & 31.0 & 95 & 11.8 & 1.03 & * \\
\hline SG 078-12-c & YB & jn08b & 16 & 2.0 & 0.3114 & 5.94 & 0.0368 & 2.87 & $0.48 !$ & 228.4 & 6.5 & 270.49 & 16.1! & 80 & 9.9 & 1.05 & \\
\hline SG 078-12-r & YB & jn08b & 17 & & 0.4193 & 4.03 & 0.0433 & 1.98 & 0.49 & 273.5 & 5.4 & 355.58 & 14.3 & 111 & 13.8 & 1.04 & \\
\hline SG 078-cr13 & YB & jn08b & $14:$ & 34.2 & 2.4211 & 5.85 & 0.0460 & 3.48 & $0.59 !$ & 192.1 & 6.7 & 967.31 & $56.6 !$ & 77 & 9.5 & 1.05 & \\
\hline SG 078-cr14 & YB & jn08b & 13 & & 0.2122 & 9.82 & 0.0306 & 2.86 & 0.29 & 194.3 & 5.6 & .40 & 19.2 & 100 & 12.4 & 1.09 & * \\
\hline SG 078-3-c & YB & jn08b & 10 & & 0.1030 & 8.17 & 0.0154 & 2.91 & $0.36 !$ & 98.7 & 2.9 & 99.58 & $8.1 !$ & 122 & 15.1 & 1.21 & * \\
\hline SG 078-cr7 & YB & jn08b & 112 & 28.9 & 2.3462 & 1.68 & 0.0599 & 1.78 & $1.06 !$ & 268.9 & 4.8 & 996.53 & 16.8 & 378 & 46.9 & 0.99 & \\
\hline SG 078-cr8 & YB & jn08b & 12 & 3.3 & 0.6287 & 4.48 & 0.0460 & 2.52 & $0.56 !$ & 280.6 & 7.1 & 482.05 & $21.6 !$ & 270 & 33.5 & 1.09 & \\
\hline SG 078-cr9 & YB & jn08b & 15 & 68.0 & 5.4543 & 4.72 & 0.0656 & 4.58 & 0.97 & & 6.1 & 1026.41 & 48.4 & 153 & 19.0 & 1.13 & \\
\hline SG 079-cr1 & YB & jn08c & 14 & & 0.3439 & 3.72 & 0.0466 & 1.13 & $0.30 !$ & 293.4 & 3.3 & 300.09 & 11.2 & 307 & 38.1 & 1.09 & * \\
\hline SG 079-2-C & YB & jn08c & 13 & 4.5 & 0.1170 & 6.96 & 0.0123 & 1.89 & 0.27 & 75.5 & 1.4 & 107.62 & 7.5 & 287 & 35.6 & 1.00 & \\
\hline SG 079-cr5 & YB & jn08c & 15 & 3.1 & 0.0966 & 7.36 & 0.0121 & 2.13 & 0.29 & 75.1 & 1.6 & 90.79 & $6.7 !$ & 285 & 35.3 & 1.01 & \\
\hline SG 079-cr5 & YB & jn08c & 16 & & & 9.75 & 0.0123 & 2.61 & 0.27 & 78.5 & 2.0 & 95.88 & $9.3 !$ & 210 & 26.0 & 1.01 & \\
\hline SG 079-cr7 & YB & jn08c & 17 & 2.1 & 0.0725 & 10.65 & 0.0123 & 2.31 & $0.22 !$ & 77.0 & 1.8 & 69.59 & $7.4 !$ & 160 & 19.8 & 1.00 & * \\
\hline SG 090-cr1 & YB & jn15b & 16 & 4.2 & 0.1217 & 20.07 & 0.0148 & 6.57 & 0.33 & 90.9 & 6.0 & 111.94 & 22.5 & 118 & 14.6 & 1.40 & * \\
\hline SG 090-cr2 & YB & jn15b & 17 & & 0.0576 & 49.54 & 0.0137 & 4.64 & 0.09 & 87.7 & 4.1 & 56.90 & $28.2 i$ & 465 & 57.7 & 1.10 & * \\
\hline SG 090-cr6 & YB & jn15b & 4 & 2.6 & 0.2781 & 16.18 & 0.0357 & 3.76 & 0.23 & 220.3 & 8.3 & 243.46 & $39.4 !$ & 166 & 20.6 & 1.20 & * \\
\hline SG 090-cr7 & YB & jn15b & 5 & & 0.6603 & 15.45 & 0.0744 & 3.75 & $0.24 !$ & 462.4 & 17.3 & 514.78 & 79.5 & 117 & 14.5 & 1.08 & * \\
\hline SG 090-cr8 & YB & jn15c & 6 & & 0.2260 & 8.26 & 0.0304 & 2.27 & 0.27 & 193.2 & 4.4 & 206.87 & 17.1 & 216 & 26.6 & 1.02 & * \\
\hline SG 090-cr9 & YB & jn15c & 7 & & 0.1250 & 15.87 & 0.0182 & 3.68 & 0.23 & 116.4 & 4.3 & 119.56 & 19.0 & 150 & 18.6 & 1.16 & * \\
\hline SG 102d-cr1 & YB & jn08a & 4 & & 0.3051 & 7.57 & 0.0401 & 1.99 & $0.26 !$ & 253.5 & 5.0 & 270.41 & 20.5 & 350 & 43.4 & 0.98 & * \\
\hline SG $102 d-c r 10$ & YB & jn08a & 10 & 1.9 & 0.0713 & 11.25 & 0.0110 & 2.54 & $0.23 !$ & 69.0 & 1.8 & 68.67 & $7.7 !$ & 301 & 37.3 & 1.08 & * \\
\hline SG $102 d-c r 11$ & YB & jn08a & 11 & 4.2 & 0.2458 & 3.83 & 0.0247 & 1.41 & 0.37 & 150.5 & 2.1 & 214.66 & 8.2 & 130 & 16.1 & 1.13 & \\
\hline SG $102 d-c r 12$ & YB & jn08a & 12 & 2.7 & 0.0904 & 8.13 & 0.0125 & 2.30 & 0.28 & 78.0 & 1.8 & 85.56 & 7.0 & 285 & 35.3 & 0.98 & * \\
\hline SG $102 d-c r 3$ & YB & jn08a & 5 & & 0.0530 & 17.76 & 0.0094 & 2.84 & $0.16 !$ & 60.5 & 1.7 & 52.44 & $9.3 !$ & 232 & 28.8 & 1.28 & * \\
\hline
\end{tabular}


Appendix 2.

\begin{tabular}{|c|c|c|c|c|c|c|c|c|c|c|c|c|c|c|c|c|c|}
\hline \multirow{2}{*}{$\begin{array}{l}\text { sample \# } \\
\text { crystal \# }\end{array}$} & \multirow{2}{*}{\multicolumn{2}{|c|}{ Region block }} & \multirow{2}{*}{\multicolumn{2}{|c|}{$\mathbf{P} \%$}} & \multirow[b]{2}{*}{${ }^{207} \mathrm{~Pb} /{ }^{235} \mathrm{U}$} & \multicolumn{3}{|c|}{ Isotope ratios } & \multirow[b]{2}{*}{ Rho } & \multirow[b]{2}{*}{${ }^{206} \mathrm{~Pb} /{ }^{238} \mathrm{U}$} & \multicolumn{2}{|c|}{ Apparent ages } & \multirow[b]{2}{*}{$2 \sigma, \mathrm{Ma}$} & \multirow[b]{2}{*}{$\mathbf{R}$} & \multirow[b]{2}{*}{$\mathbf{S}$} & \multirow[b]{2}{*}{$A / \ln$} & \multirow[b]{2}{*}{ C } \\
\hline & & & & & & $2 \sigma, \%$ & ${ }^{206} \mathrm{~Pb} /{ }^{238} \mathrm{U}$ & $2 \sigma, \%$ & & & $2 \sigma, \mathrm{Ma}$ & ${ }^{207} \mathrm{~Pb} /{ }^{235} \mathrm{U}$ & & & & & \\
\hline SG $102 d-c r 5$ & YB & jn08a & 7 & & 0.0875 & 4.68 & 0.0128 & 1.40 & $0.30 i$ & 81.8 & 1.1 & 85.17 & $4.0 i$ & 292 & 36.2 & 1.00 & * \\
\hline SG 102d-cr7 & YB & jn08a & 8 & & 0.0892 & 7.39 & 0.0122 & 2.21 & $0.30 !$ & 78.1 & 1.7 & 86.74 & $6.4 !$ & 300 & 37.2 & 0.97 & \\
\hline SG 102d-cr8 & YB & jn08a & 9 & & 0.2560 & 4.54 & 0.0353 & 1.41 & $0.31 !$ & 223.7 & 3.1 & 231.42 & 10.5 & 427 & 52.9 & 1.03 & * \\
\hline SG 103-cr10 & YB & jn08d & 10 & & 0.0933 & 5.80 & 0.0126 & 2.72 & $0.47 !$ & 81.0 & 2.2 & 90.56 & $5.3 i$ & 377 & 46.7 & 1.01 & \\
\hline SG 103-cr11 & YB & jn08d & 11 & & 0.0673 & 14.35 & 0.0127 & 3.39 & $0.24 !$ & 81.3 & 2.8 & 66.13 & 9.5 & 362 & 44.9 & 1.08 & \\
\hline SG 103-cr2-c & YB & jn08d & 4 & & 0.0608 & 22.19 & 0.0115 & 3.61 & $0.16 !$ & 74.0 & 2.7 & 59.90 & $13.3 !$ & 401 & 49.7 & 1.14 & * \\
\hline SG 103-cr3 & YB & jn08d & 5 & & 0.0799 & 10.30 & 0.0118 & 3.46 & $0.34 !$ & 75.7 & 2.6 & 78.03 & $8.0 !$ & 403 & 50.0 & 1.05 & * \\
\hline SG 103-cr6 & YB & jn08d & 6 & & 0.0805 & 13.79 & 0.0113 & 3.51 & $0.25 !$ & 72.3 & 2.5 & 78.65 & $10.8 !$ & 363 & 45.0 & 1.06 & * \\
\hline SG 103-cr7 & YB & jn08d & 7 & & 0.0832 & 13.15 & 0.0122 & 3.62 & $0.28 !$ & 78.1 & 2.8 & 81.10 & $10.7 !$ & 374 & 46.4 & 1.07 & * \\
\hline SG 103-cr8 & YB & jn08d & 8 & 3.4 & 0.0657 & 16.01 & 0.0126 & 3.71 & $0.23 !$ & 78.0 & 2.9 & 62.50 & $10.0 !$ & 316 & 39.2 & 1.03 & \\
\hline SG 103-cr9 & YB & jn08d & 9 & & 0.0755 & 10.95 & 0.0116 & 3.26 & $0.30 !$ & 74.2 & 2.4 & 73.91 & $8.1 !$ & 369 & 45.8 & 1.15 & * \\
\hline
\end{tabular}

\section{Additional sphene analyses}

\begin{tabular}{|c|c|c|c|c|c|c|c|c|c|c|c|c|c|c|c|c|}
\hline \multirow{2}{*}{$\begin{array}{l}\text { sample \# } \\
\text { crystal \# }\end{array}$} & \multirow[b]{2}{*}{ Region } & \multirow[b]{2}{*}{ block } & & \multirow[b]{2}{*}{$\mathbf{P} \%$} & \multicolumn{5}{|c|}{ Isotope ratios } & \multicolumn{3}{|c|}{ Apparent ages } & \multirow[b]{2}{*}{$\mathbf{R}$} & \multirow[b]{2}{*}{$\mathbf{S}$} & \multirow[b]{2}{*}{$A / I n$} & \multirow[b]{2}{*}{ C } \\
\hline & & & & & $\begin{array}{c}{ }^{207} \mathrm{~Pb} / \\
{ }^{235} \mathrm{U}\end{array}$ & $2 \sigma, \%$ & $\begin{array}{c}{ }^{206} \mathrm{~Pb} / \\
{ }^{238} \mathrm{U}\end{array}$ & $2 \sigma, \%$ & Rho & $\begin{array}{c}{ }^{206} \mathrm{~Pb} / \\
{ }^{238} \mathrm{U}\end{array}$ & $2 \sigma, \mathrm{Ma}$ & $\begin{array}{c}{ }^{207} \mathrm{~Pb} / \\
{ }^{235} \mathrm{U}\end{array}$ & & & & \\
\hline SG 063-3-sphene & YB & jn08a & 15 & 49.4 & 1.8025 & 15.52 & 0.0261 & 5.58 & 0.36 & 84.7 & 4.7 & 658.03 & 187 & 23.2 & 0.83 & \\
\hline ST-25-1-sphene & Str & jn08c & 4 & 7.7 & 0.1743 & 7.50 & 0.0128 & 2.75 & 0.37 & 75.6 & 2.1 & 151.52 & 458 & 56.8 & 1.01 & \\
\hline ST-25-2-sphene & Str & jn08c & 5 & 23.8 & 0.2718 & 21.75 & 0.0135 & 7.03 & 0.32 & 65.8 & 4.6 & 191.21 & 251 & 31.1 & 1.09 & \\
\hline ST-25-4-sphene & Str & jn08c & 6 & 11.4 & 0.5314 & 12.58 & 0.0164 & 4.10 & 0.33 & 93.3 & 3.8 & 391.92 & 456 & 56.5 & 1.01 & \\
\hline ST-25-5-sphene & Str & jn08c & 7 & 17.4 & 0.2195 & 14.23 & 0.0143 & 3.22 & 0.23 & 75.9 & 2.4 & 169.18 & 412 & 51.1 & 1.00 & \\
\hline SG 068-sphene-cr3 & EB & $\mathrm{ma04f}$ & 15 & 43.6 & 0.7555 & 12.14 & 0.0154 & 5.96 & 0.49 & 55.7 & 3.3 & 360.38 & 65 & 8.9 & 1.03 & \\
\hline SG 068sphene-cr5 & EB & ma04f & 16 & 11.2 & 0.7060 & 8.19 & 0.0137 & 4.61 & 0.56 & 87.9 & 4.1 & 542.40 & 210 & 28.8 & 1.02 & \\
\hline
\end{tabular}




\section{Appendix 3. U-Pb age results by sample}

$\mathrm{U}-\mathrm{Pb}$ age results for Eastern Srednogorie zone are presented below, starting with the southernmost Strandzha region through the intermediate Yambol-Burgas and North Burgas regions and finally for the northernmost East Balkan region. Location of samples and regions is shown on Figure 3-1. For each sample the data are presented as a series of graphs, constructed with the ISOPLOT add-in for Excel (Ludwig, K. R., 2003, Berkeley Geochronology Center Special Publication 4). We gave preference to ID-TIMS ages over LAICPMS data, where sufficient numbers of zircon grains were analyzed by both methods. Depending on sample population and number of studied grains, concordia ages were preferred rather than upper - or lower intercept ages or weighted averages of ${ }^{206} \mathrm{~Pb} /{ }^{238} \mathrm{U}$ ages. Intercept ages and weighted ${ }^{206} \mathrm{~Pb} /{ }^{238} \mathrm{U}$ ages were filtered based on the number of grains and MSWD values. 
Appendix 3.

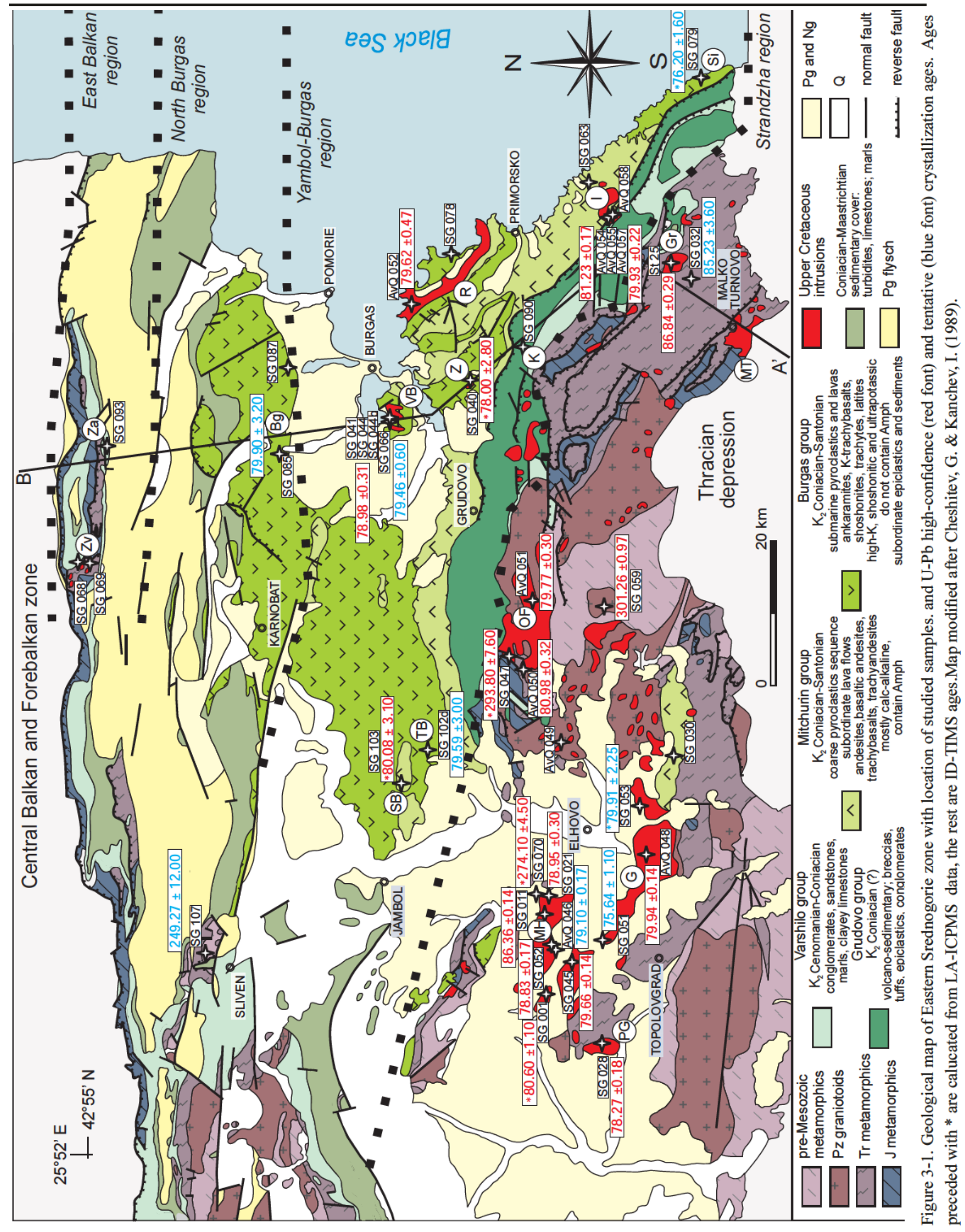




\section{AvQ 046 - Gabbro, Monastery Heights}

The sample is taken close to the village of Goljam Manastir, and is representative for the basic intrusive phase of Monastery Heights pluton. Four zircons air-abraded for 2 hours and analyzed by ID-TIMS plot on the concordia band between 79 and $105 \mathrm{Ma}$, without overlapping, and with increasing ${ }^{207} \mathrm{~Pb} /{ }^{235} \mathrm{U}$ errors from the youngest to the oldest (Figure 3-2a). The youngest zircon has the smallest errors, and its concordia age of $79.10 \pm 0.17$ Ma most likely represents the crystallization age of the sample (Figure 3-2b). The remaining three zircons were probably entrapped during assimilation of host rocks from the gabbroic magma. It remains unclear whether the $92.4 \mathrm{Ma}$ and especially the $104.4 \mathrm{Ma}{ }^{206} \mathrm{~Pb} /{ }^{238} \mathrm{U}$ ages represent magmatic events, or the $\mathrm{U}-\mathrm{Pb}$ systematic of the grains had been disturbed by the presence of older component or $\mathrm{Pb}$ loss (large ${ }^{207} \mathrm{~Pb} /{ }^{235} \mathrm{U}$ errors prevent further interpretation). LA-ICPMS results on 5 zircons generally agree with the ID-TIMS age range, except for one grain with considerably older age (Figure 3-3).

a

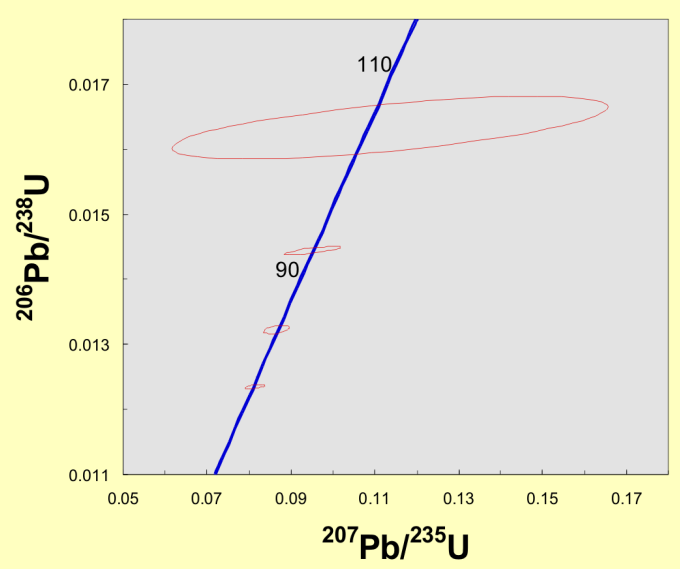

b

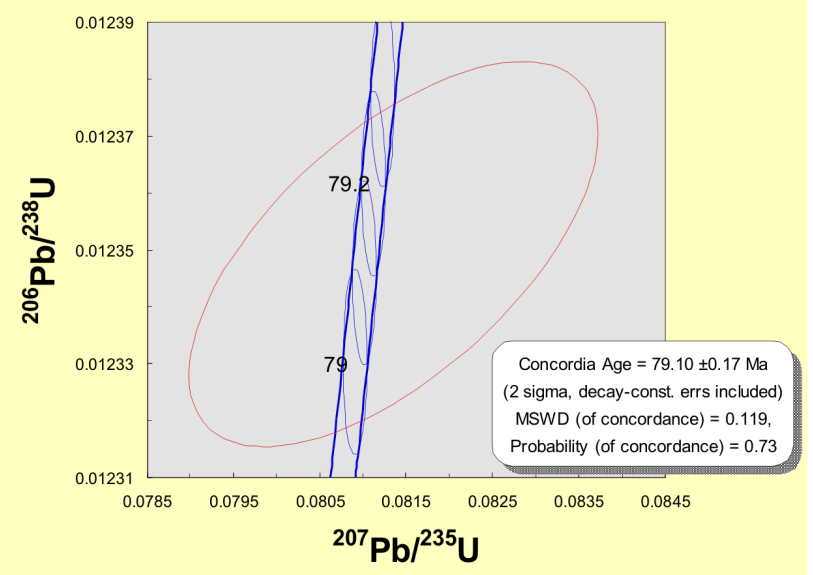

Figure 3-2. Results from single zircon U-Pb ID-TIMS dating for sample AvQ 046

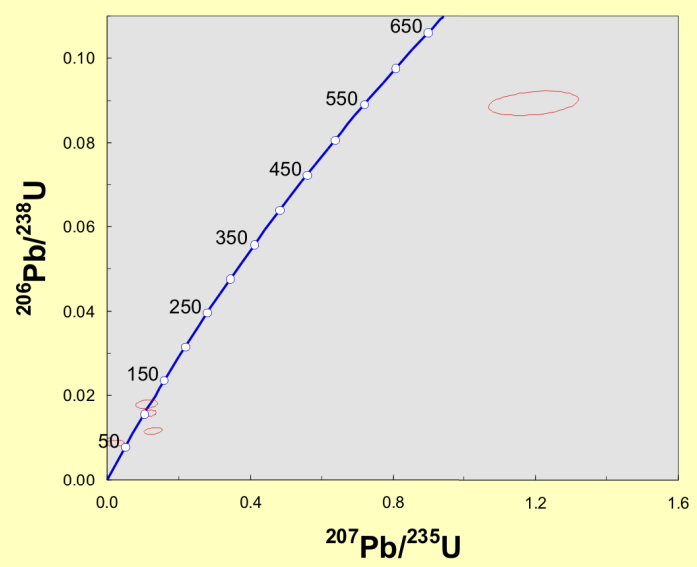

Figure 3-3. Results from single zircon U-Pb LA-ICPMS dating for sample AvQ 046

\section{AvQ 048 - Granodiorite, Granitovo}

Granitovo pluton is the largest granitic intrusion in the Strandzha region and the whole Eastern Srednogorie. Fifteen zircons were analyzed by ID-TIMS. Five of them show evidence for incorporation of older component and lie to the right of the concordia band with ${ }^{206} \mathrm{~Pb} /{ }^{238} \mathrm{U}$ ages ranging from 100 to $130 \mathrm{Ma}$ (Figure 3-4a). Four air abraded zircons yield two possible ages, one at $78 \mathrm{Ma}$ and another one at $80 \mathrm{Ma}$ with unclear relations (Figure 3-4b). Six chemically abraded zircons plot closer to the older, $\sim 80 \mathrm{Ma}$ age. The chemically 
a

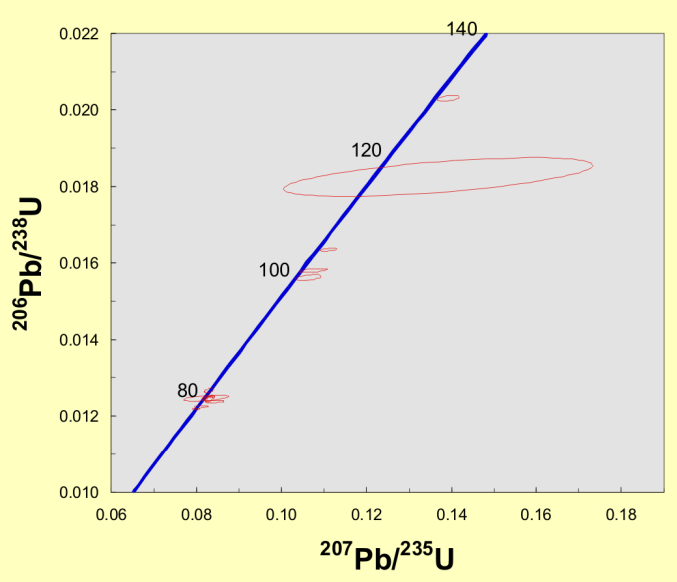

C

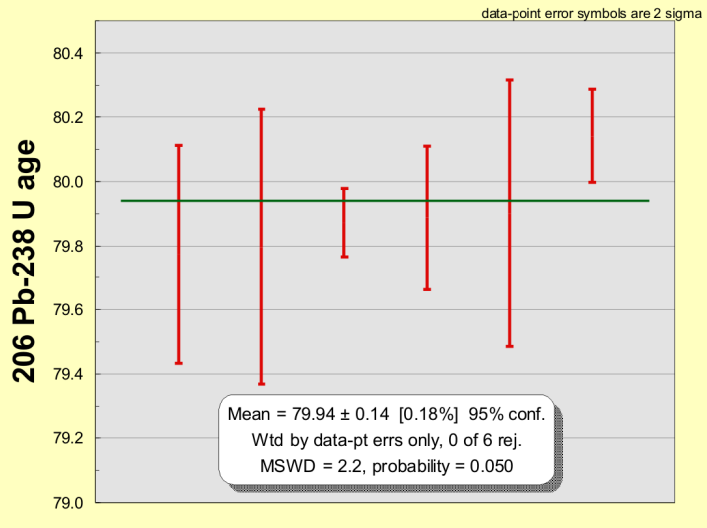

e

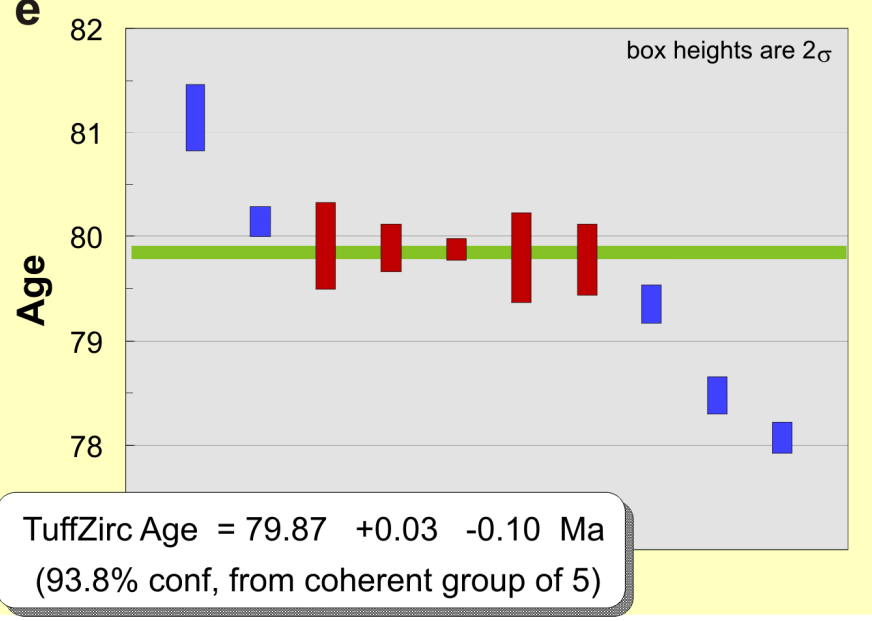

b

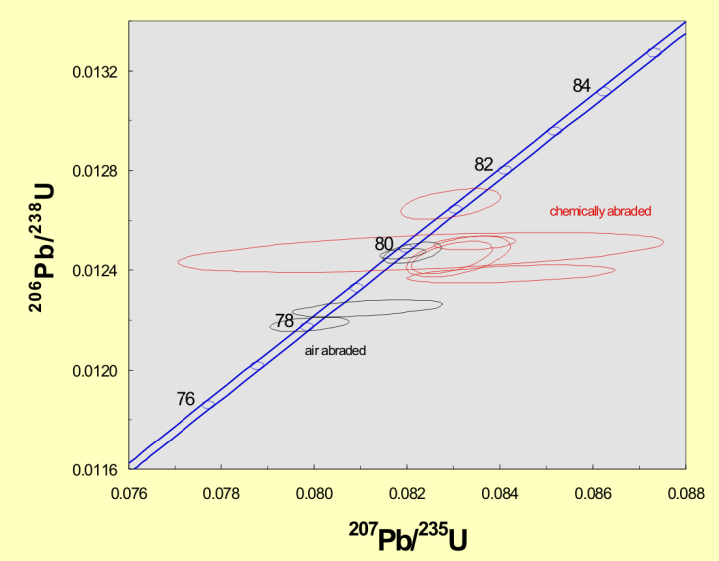

d

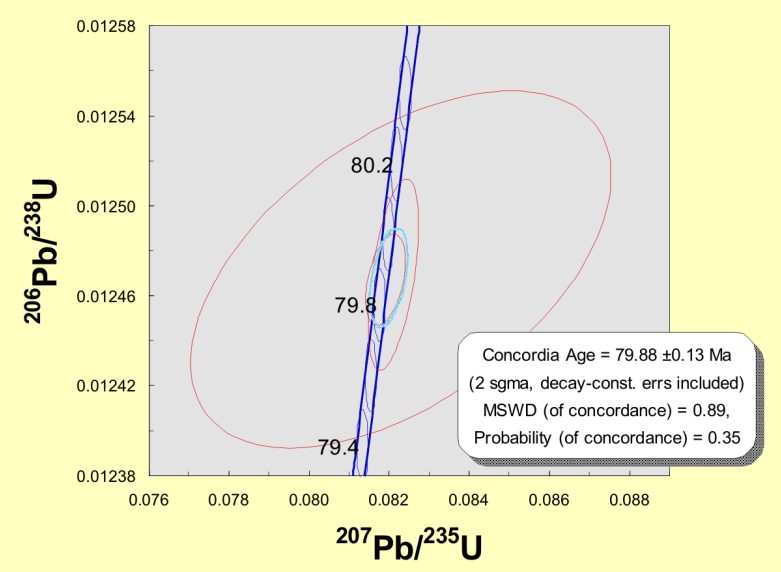

$\mathbf{f}$

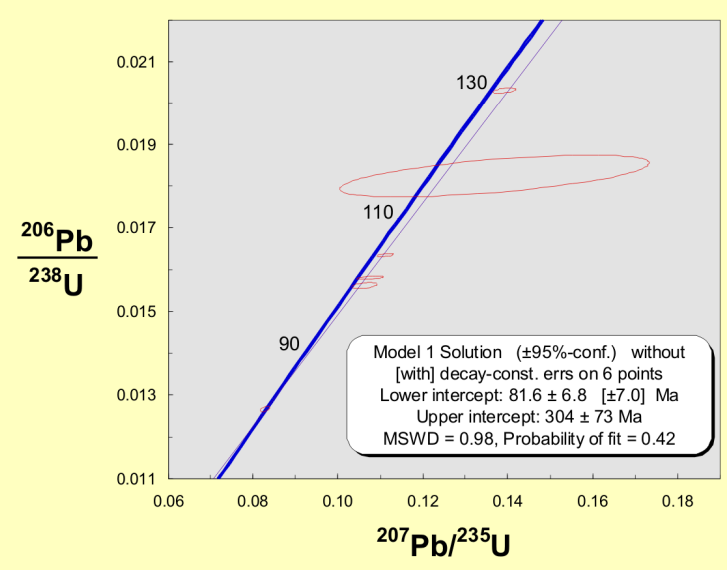

Figure 3-4. Results from single zircon U-Pb ID-TIMS dating for sample AvQ 048

abraded zircons show some discordance signaling insufficient annealing/leaching steps; the chemical abrasion procedure was being established establishing at the time. Nevertheless, they all have consistent ${ }^{206} \mathrm{~Pb} /{ }^{238} \mathrm{U}$ ages coinciding with the ages of the two older air abraded zircons and therefore we consider the weighted average $79.94 \pm 0.14 \mathrm{Ma}^{206} \mathrm{~Pb} /{ }^{238} \mathrm{U}$ age of 6 zircons to represent the crystallization age of the granite (Figure 3-4c). Similar age and error are obtained if we use the concordia age of three zircons (Figure 3-4d), or the zircon age extractor algorithm for all Late Cretaceous zircons (Figure 3-4e). The constructed discordia chord from the older zircons and either of the Late Cretaceous zircons indicate a Carboniferous/Permian inherited component in those zircon grains (Figure 3-4f). Most of the fifteen grains, analyzed by LA ICPMS form a coherent group with a weighed average ${ }^{206} \mathrm{~Pb} /{ }^{238} \mathrm{U}$ age of $79.8 \pm 2.4 \mathrm{Ma}$ (Figure 3-5a). The larger spread of the LAICPMS individual ages compared to the TIMS data is reflected in the higher MSWD value of 7.9. The relative 
probability plot of the LA-ICPMS zircon data and the applied unmixing of ages show a prominent peak at $80.35 \pm 0.71 \mathrm{Ma}$ (Figure 3-5b). The zircon age extractor algorithm gives a slightly younger, but nevertheless overlapping within the error age (Figure 3-5c). The oldest analyzed zircon core has a Permian age.

a
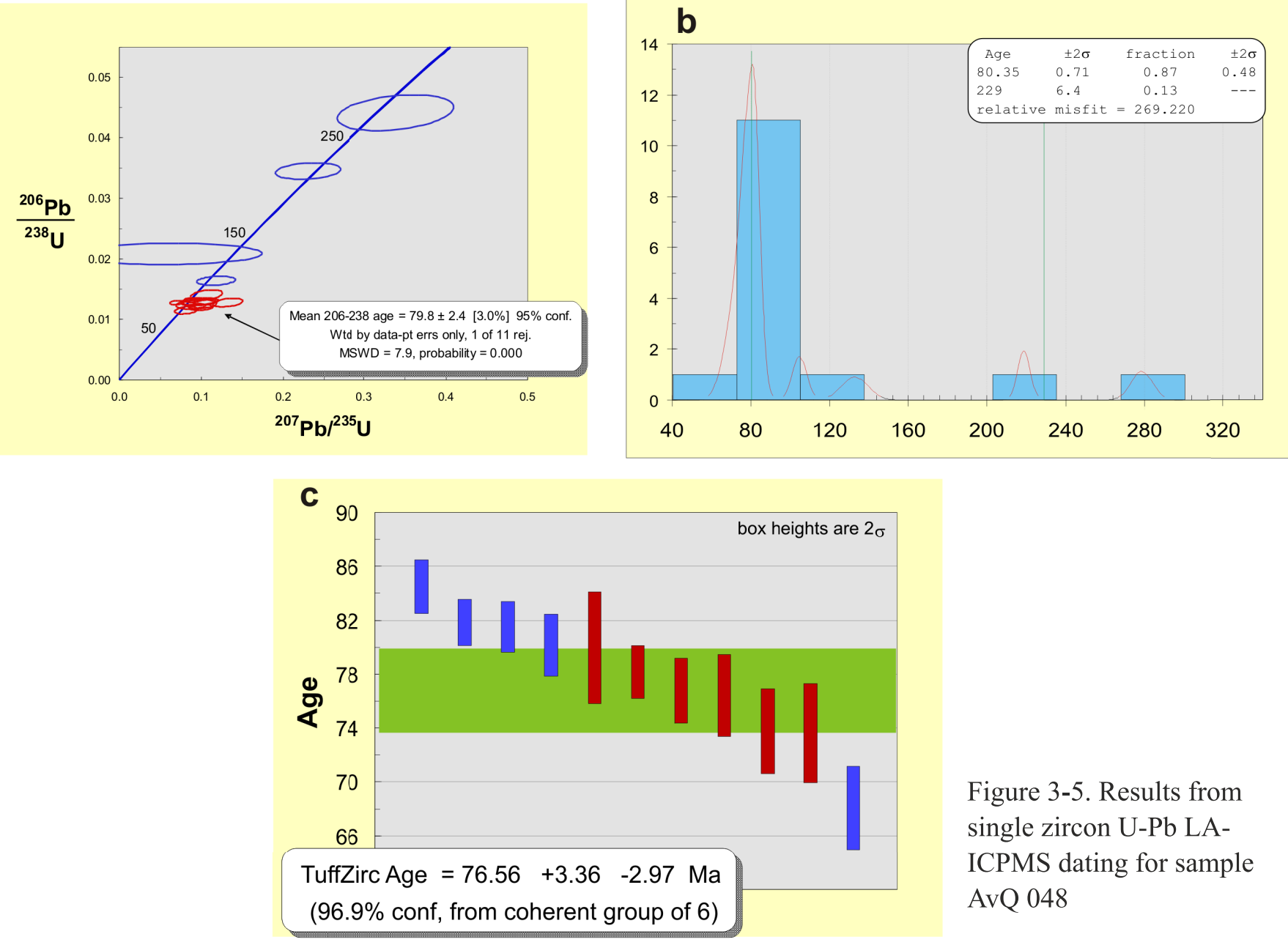

Figure 3-5. Results from single zircon U-Pb LAICPMS dating for sample AvQ 048

\section{AvQ 050 - Amph Gabbro, Oman-Fakya}

Three zircon grains were air-abraded for 7 hours and analyzed by ID-TIMS. The zircons still show

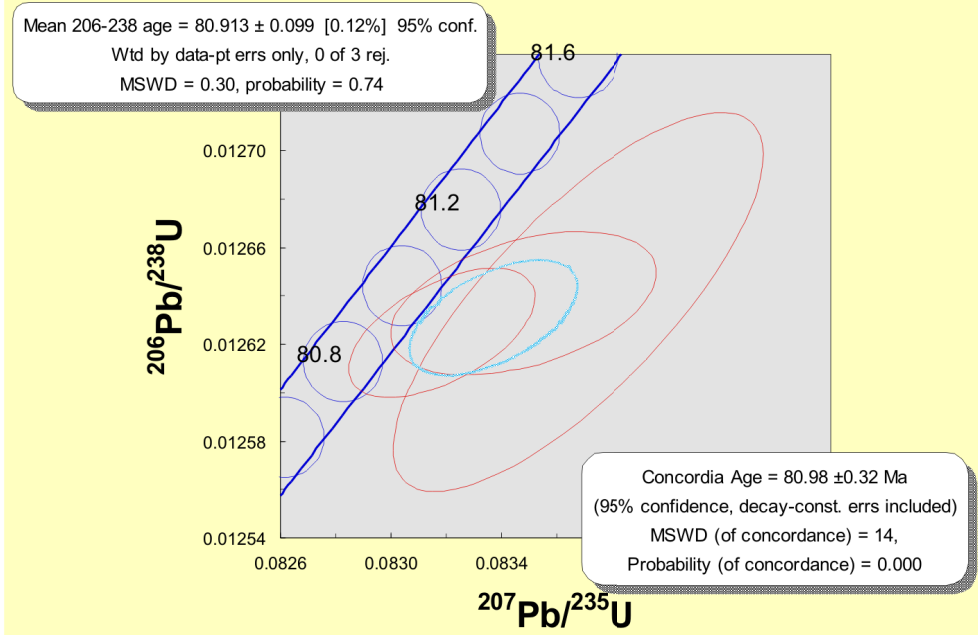

Figure 3-6. Results from single zircon U-Pb ID-TIMS dating for sample AvQ 050 minimal evidence of $\mathrm{Pb}$ loss but nevertheless yield a concordant age of $80.98 \pm 0.32 \mathrm{Ma}$ at the 95\% confidence level (Figure 3-6), which we consider to be the crystallization age of the rock. The weighted average ${ }^{206} \mathrm{~Pb} /{ }^{238} \mathrm{U}$ age is $80.91 \pm$ $0.09 \mathrm{Ma}$, which equivalent within errors to the Concordia age.

Nine grains dated by LA-ICPMS all show Late Cretaceous ages (Figure 3-7a). Although individual measurement errors are high, the probability plot indicates a peak at ca. $80 \mathrm{Ma}$ (Figure 3-7b) and the zircon age extraction algorithm also yields an age consistent with the TIMS data, but with larger errors (Figure 3-7c). 
a

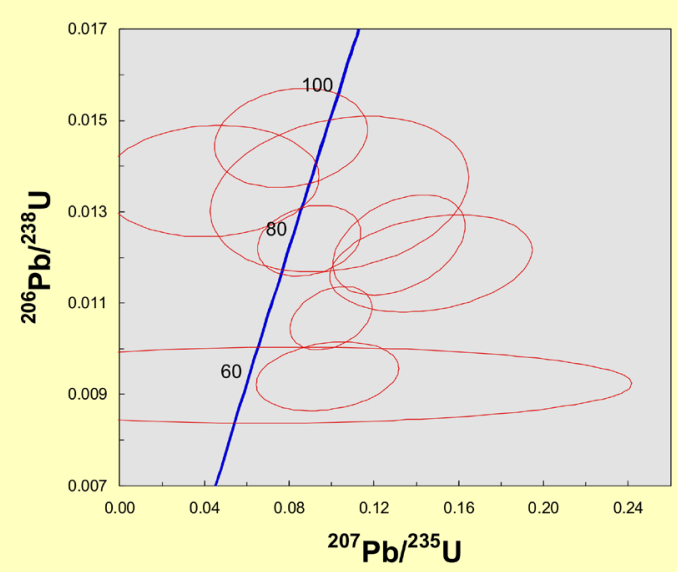

b

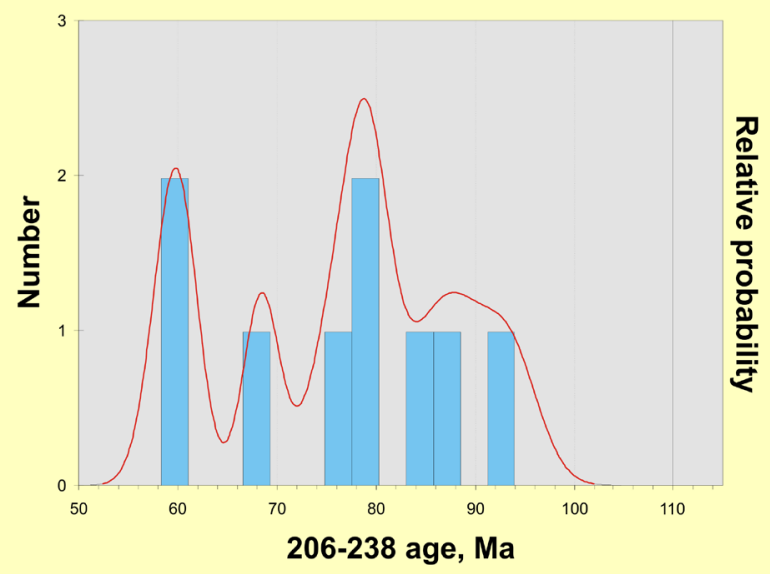

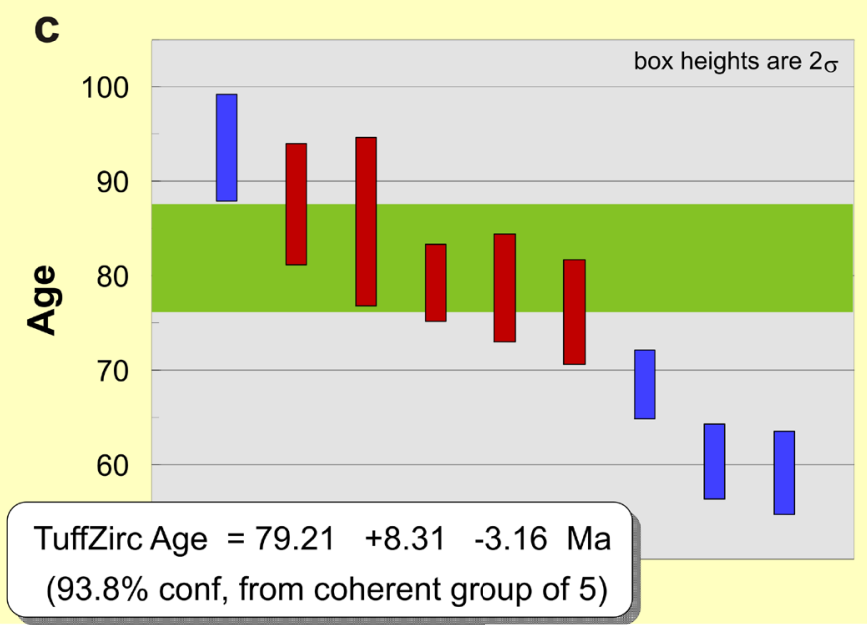

Figure 3-7. Results from single zircon U-Pb LA-ICPMS dating for sample AvQ 050

\section{AvQ 051 - Qz leucosyenite, Oman-Fakya}

Six zircons were air-abraded for 7 hours and analyzed by ID-TIMS. Five zircons form a discordia line with a lower intercept at 82.2 $\pm 3.9 \mathrm{Ma}$ and upper intercept at 332.8 \pm 9.0 Ma, MSWD $=0.42$ (Figure 3-8a). Three grains are concordant at $79.77 \pm 0.30 \mathrm{Ma}$ at the $95 \%$ confidence level (Figure 3-8b). The two zircons with larger errors and slightly lower ${ }^{206} \mathrm{~Pb} /{ }^{238} \mathrm{U}$ age on the diagram may have experienced minor $\mathrm{Pb}$ loss.

Additional six grains were dated by LA-ICPMS (Figure 3-9a). Three zircons yield a concordant age of $81.8 \pm 3.5 \mathrm{Ma}$ at the $95 \%$ confidence level, which overlaps with the ID-TIMS age. The weighted average ${ }^{206} \mathrm{~Pb} /{ }^{238} \mathrm{U}$ age and the zircon extraction age are also similar (Figure 3-9a, c). Two iherited grains have Carboniferous/Permian ages (Figure 3-9a, c, d).

a

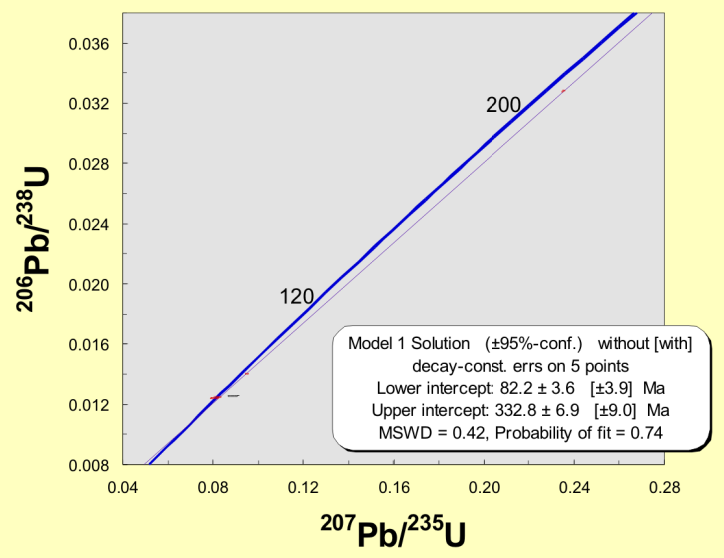

b

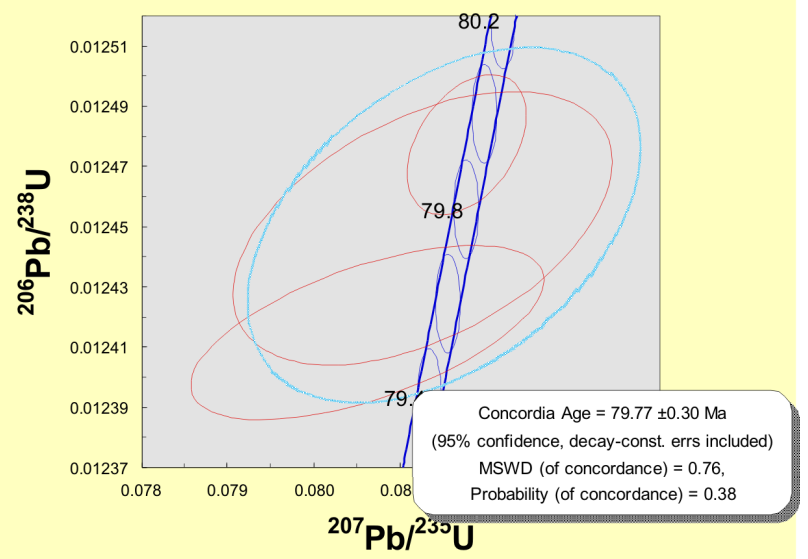

Figure 3-8. Results from single zircon U-Pb ID-TIMS dating for sample AvQ 051 
a

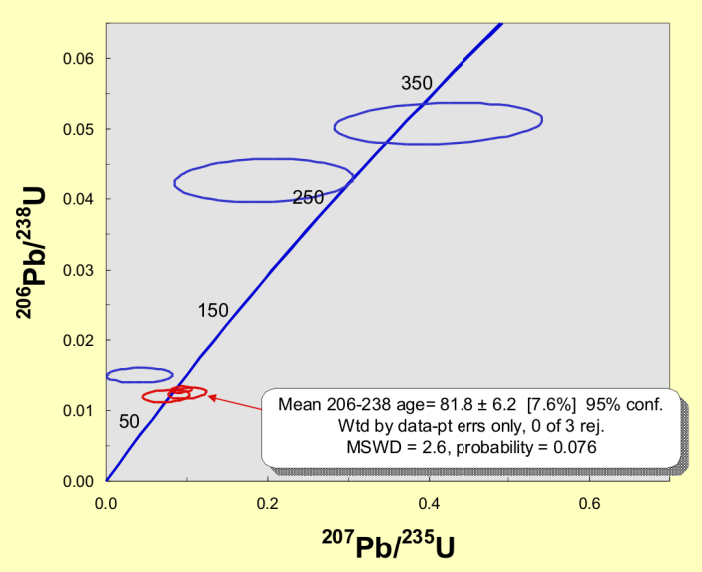

C

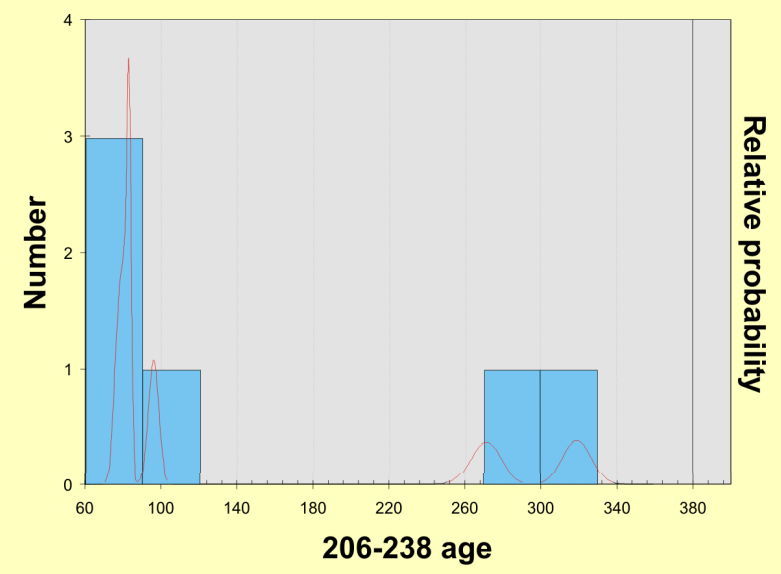

b

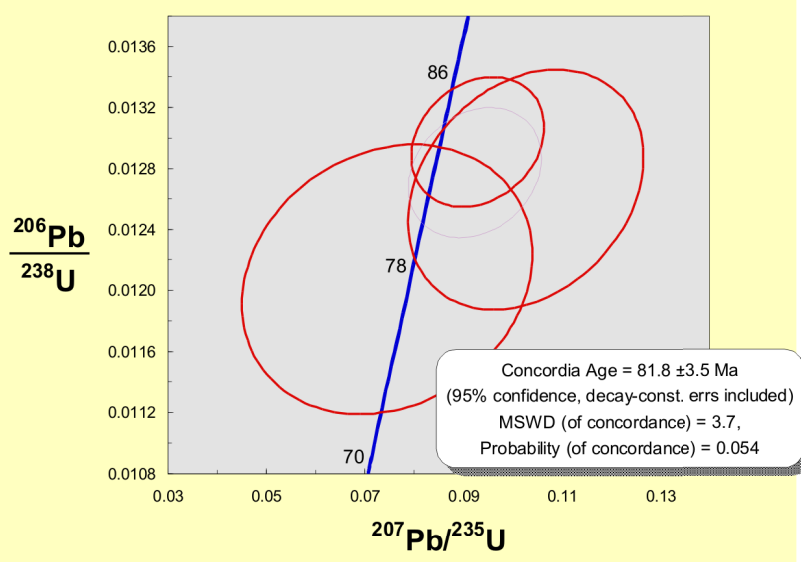

d

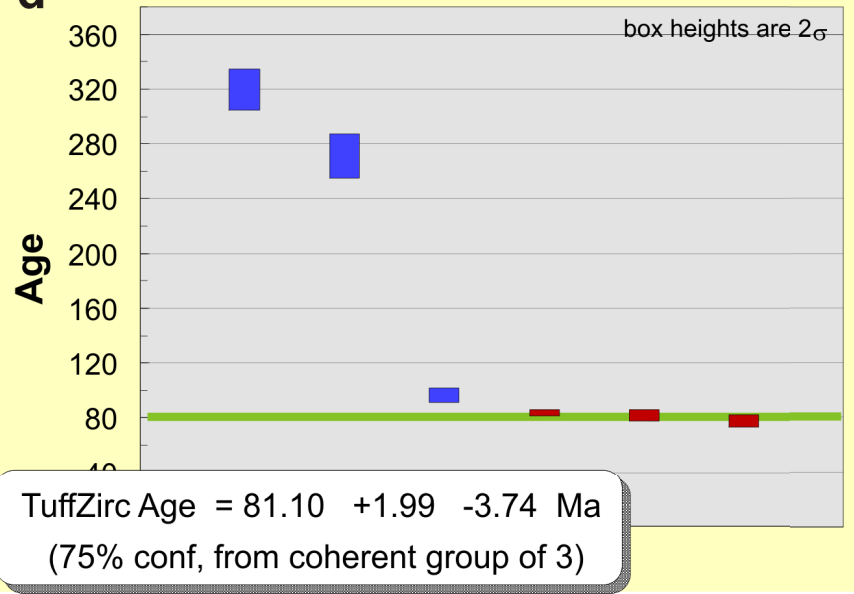

Figure 3-9. Results from single zircon U-Pb LA-ICPMS dating for sample AvQ 051

\section{SG 001 - Granodiorite, Monastery Heights}

The sample is collected near the village of Ovtchi Kladenetz and represents the granodioritic phase of the Monastery Heights intrusion. Results for ten zircons dated by LA-ICPMS are presented on Figure 3-10. The concordia age formed by three grains at 80.6 $\pm 1.1 \mathrm{Ma}, 2$ sigma errors (Figure 3-10b) is considered as the best estimate for the crystallization age of the granodiorite. Discernibly older inherited components are not detected in this sample. One grain shows younger age of $66 \mathrm{Ma}$, which is probably a result of overcorrection for common $\mathrm{Pb}$.

\section{SG 011 - Diorite, Monastery Heights}

This sample, collected between the villages of Goljam Manastir and Krumovo is representative of the diorite phase of the Monastery Heights pluton. Five zircon grains, air abraded for 6 hours, were analyzed by ID-TIMS and they all yield similar ages (Figure 3-11a). Three of the zircons yield a well defined concordia age of $86.31 \pm 0.14 \mathrm{Ma}$, which is considered as the crystallization age of the rock. The remaining two grains have slightly younger ages with larger errors. Their anomalously low ${ }^{206} \mathrm{~Pb}^{*} / 204 \mathrm{~Pb}$ ratios of 37 and 47 which indicates a large proportion of common $\mathrm{Pb}$ either from within the grain, or from contamination.

LA-ICPMS age results for thirteen zircons from this sample are presented on Figure 3-12a. The mean ${ }^{206} \mathrm{~Pb} /{ }^{238} \mathrm{U}$ age for the whole population is $85.3 \pm 3.2 \mathrm{Ma}$ at the $95 \%$ confidence level and the MSWD is high (26). The relative probability is highest at $87 \mathrm{Ma}$ (Figure 3-12c), and this is the age resulting from the zircon tuff age algorithm as well (Figure 3-12d). Five grains are concordant within their errors at $87.8 \pm 1.0 \mathrm{Ma}$ (Figure 3-12b), an age similar to the well defined ID-TIMS concordia age. 
a

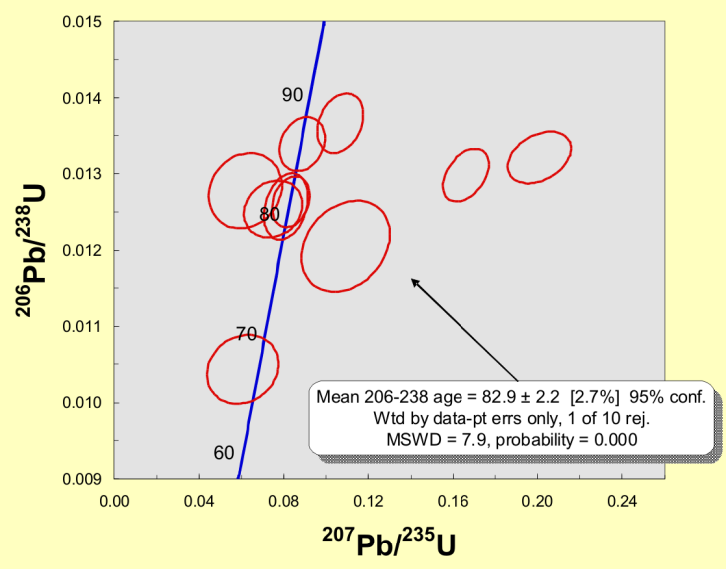

C

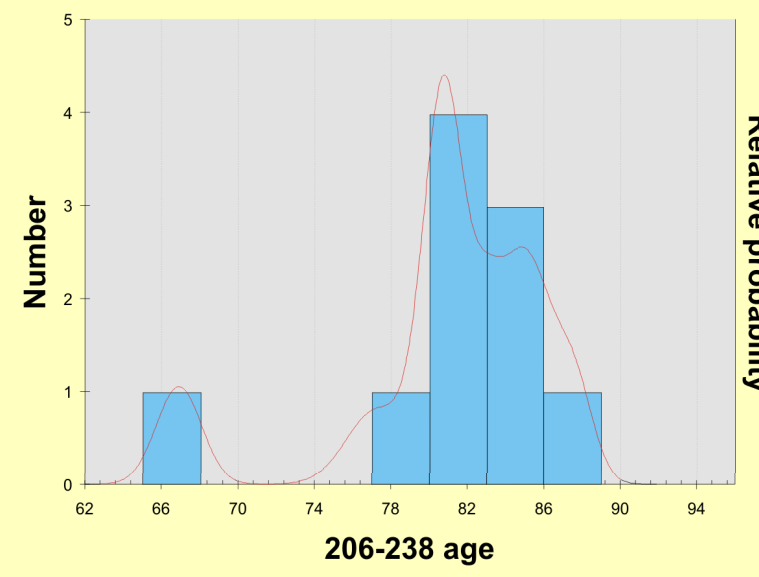

b
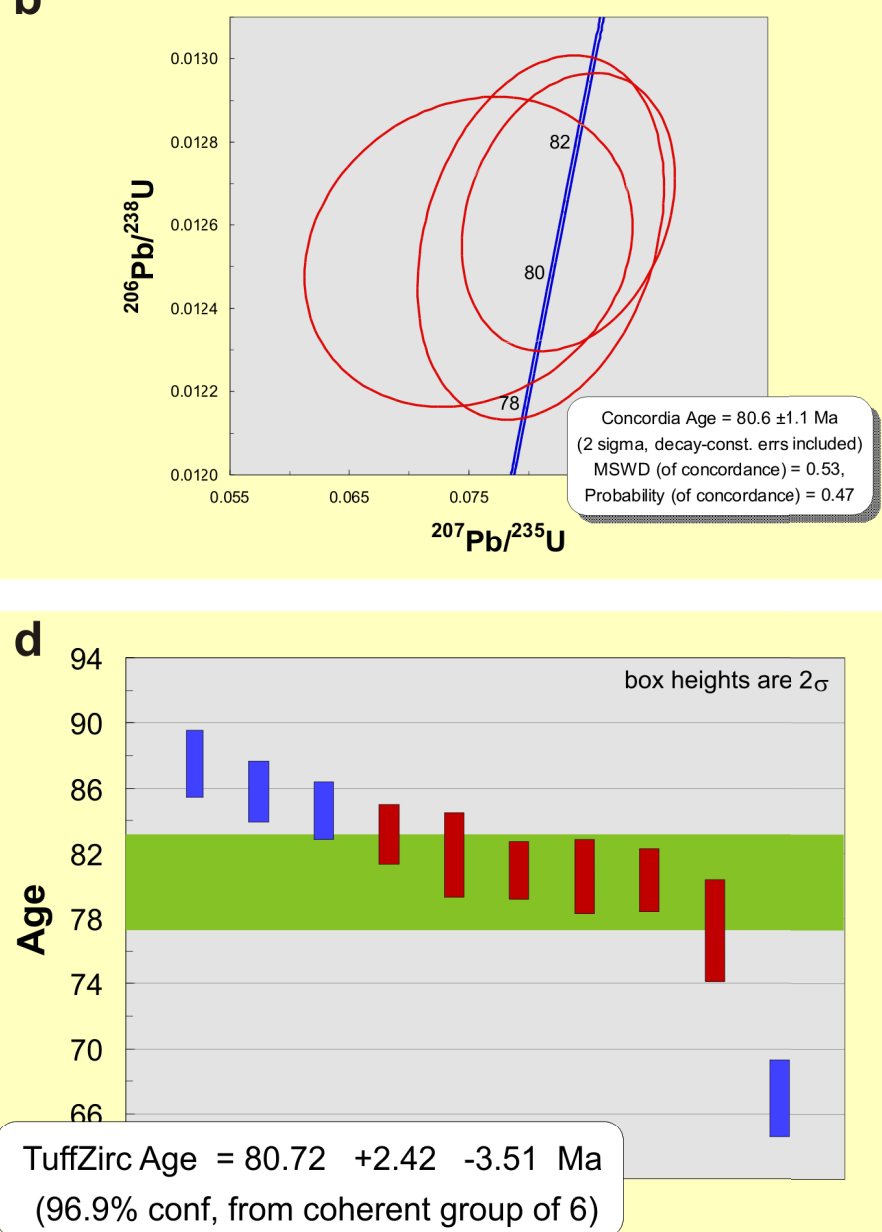

Figure 3-10. Results from single zircon U-Pb LA-ICPMS dating for sample SG 001

a

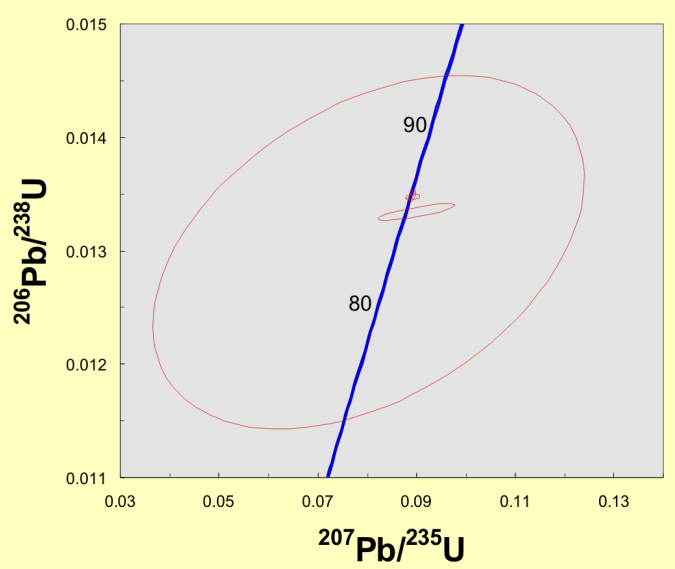

b

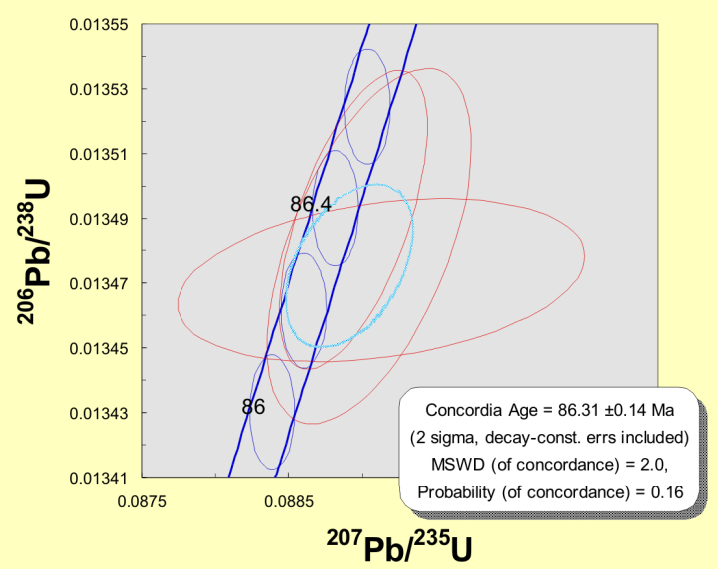

Figure 3-11. Results from single zircon U-Pb ID-TIMS dating for sample SG 011 
a

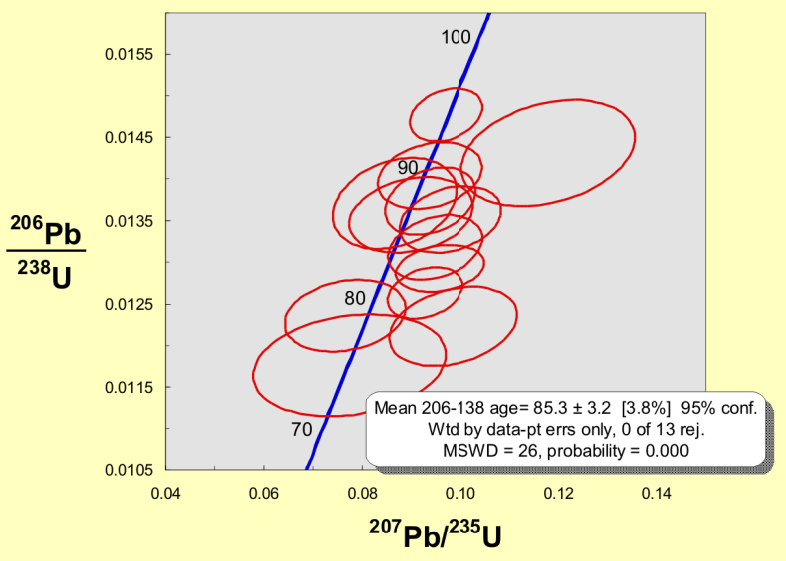

C

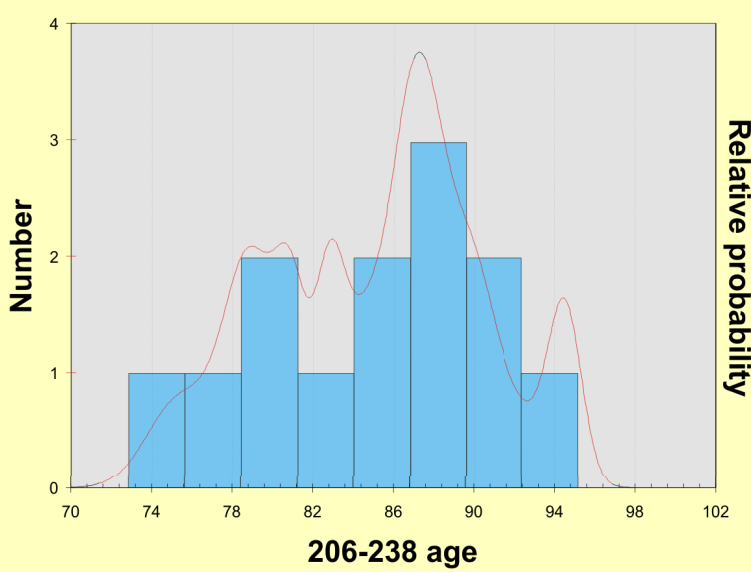

b
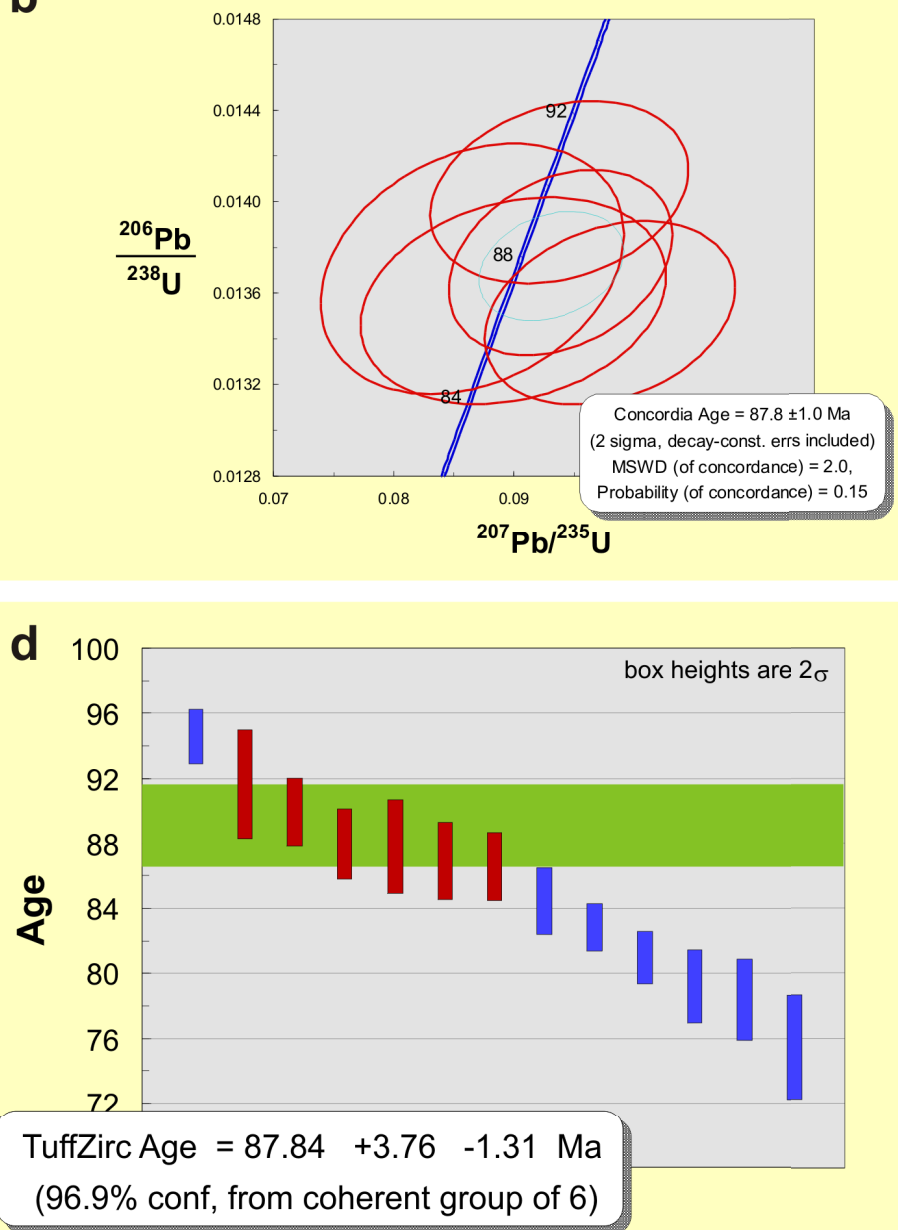

Figure 3-12. Results from single zircon U-Pb LA-ICPMS dating for sample SG 011

\section{SG 021 - Basaltic andesite dike, Monastery Heights}

The dike crosscuts a basic medium-grained intrusion near the Drama village, at the eastern part of Monastery Heights pluton. Four zircons were analyzed by ID-TIMS (Figure 3-13a). Three zircons are concordant within their errors and yield a $78.95 \pm 0.30$ Ma concordia age at the $95 \%$ confidence limit (Figure $3-13 \mathrm{~b}$ ). Two of the concordant zircons have low ${ }^{206} \mathrm{~Pb}^{*} / 204 \mathrm{~Pb}$ ratios of 46 and 48 and the zircon with highest ${ }^{206} \mathrm{~Pb}^{*} / 204 \mathrm{~Pb}$ ratios has the oldest ${ }^{206} \mathrm{~Pb} /{ }^{238} \mathrm{U}$ age within this group. One grain has older discordant ages and together with the remaining zircons forms a discordia line with an upper intercept age of $546 \pm 35 \mathrm{Ma}$,

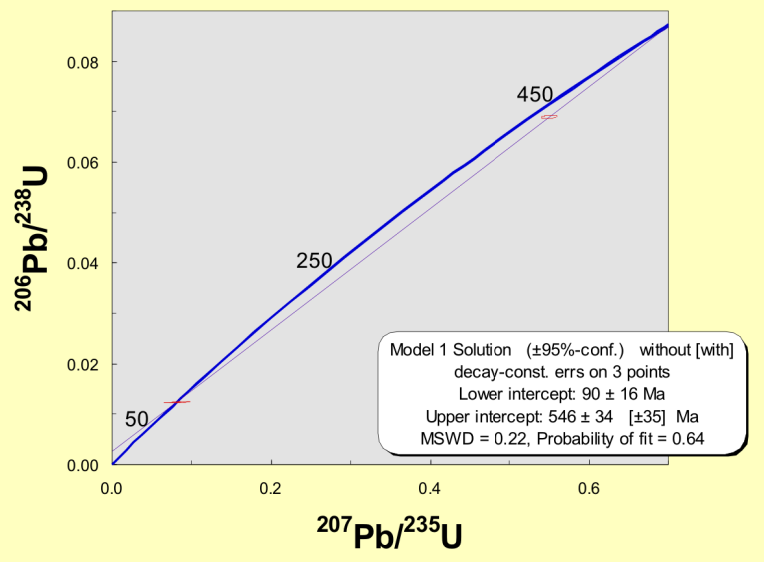

b

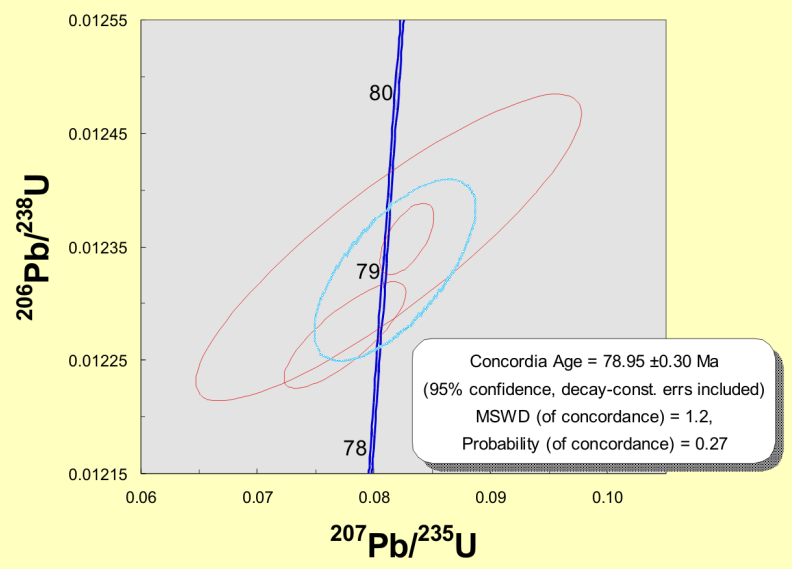

Figure 3-13. Results from single zircon U-Pb ID-TIMS dating for sample SG 021 
indicating a possible Neoproterozoic/Cambrian inheritance. Five zircons were dated by LA-ICPMS, which proved insufficient for a confident age determination (Figure 3-14a, b).

a

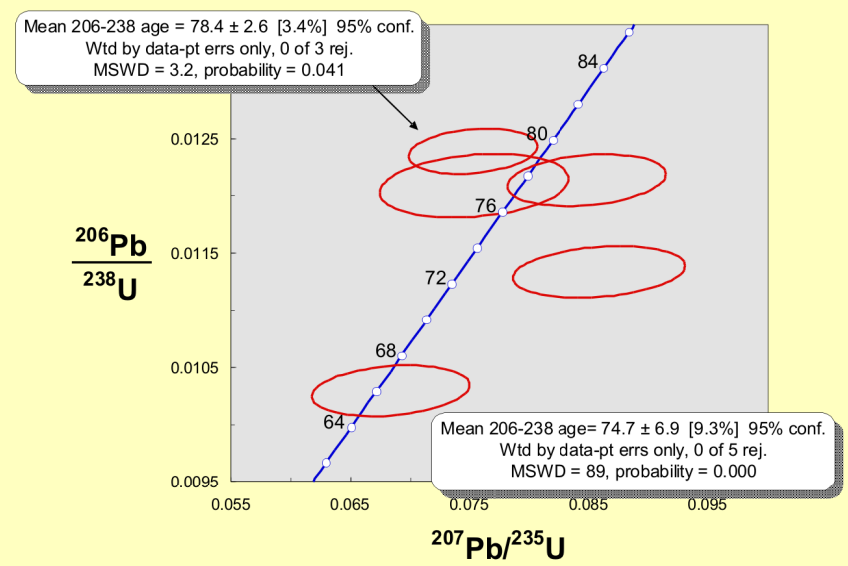

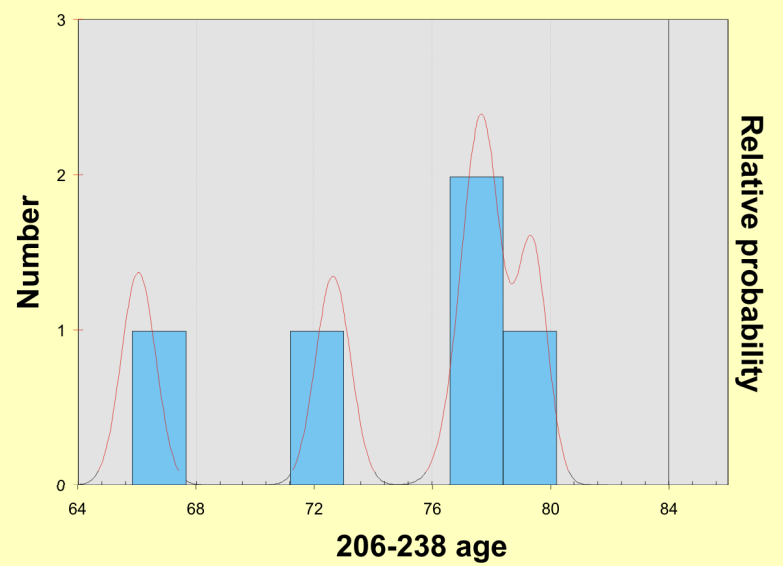

Figure 3-14. Results from single zircon U-Pb LA-ICPMS dating for sample SG 021

\section{SG 028 - Granodiorite, Polski Gradetz pluton}

Seven zircon grains were air abraded for 3 hours and dated by U-Pb ID-TIMS. On a concordia plot, four grains are situated around $78 \mathrm{Ma}$ and three grains have older ${ }^{206} \mathrm{~Pb} /{ }^{238} \mathrm{U}$ ages from 80 to $90 \mathrm{Ma}$ (Figure 3-15a). When regressed together, all zircons form a chord with MSWD of 4 and very imprecise and geologically unreasonable upper intercept age. The most concordant zircon yields a concordia age of $78.27 \pm 0.18 \mathrm{Ma}, 2$ sigma errors (Figure 3-15b). Two other zircons are overstepping partly the concordia band and yield a 77.63

a

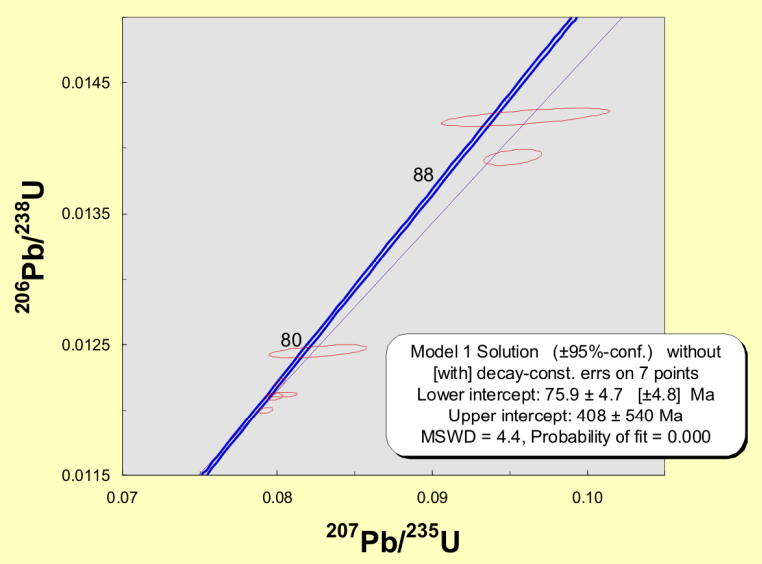

C

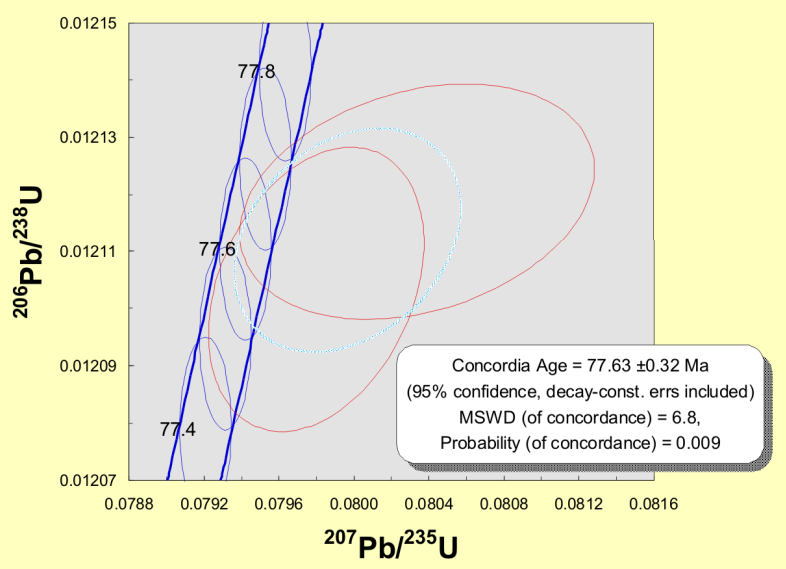

b

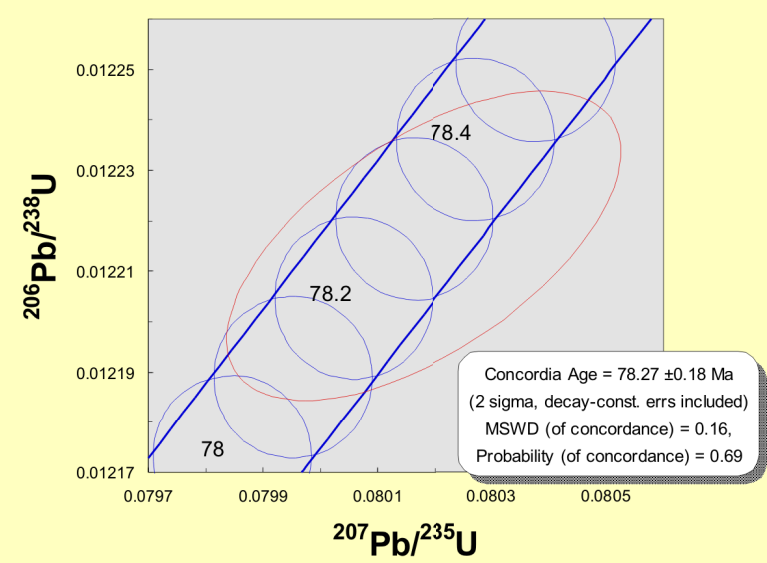

d

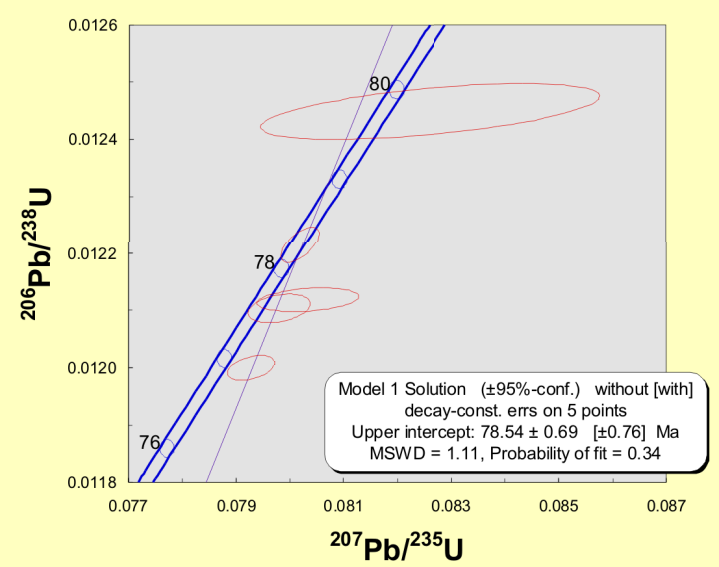

Figure 3-15. Results from single zircon U-Pb ID-TIMS dating for sample SG 028 
$\pm 0.32 \mathrm{Ma}$ concordia age at the $95 \%$ confidence limit (Figure $3-15 \mathrm{c}$ ). These two grains may be younger than the concordant zircon at $78.27 \pm 0.18 \mathrm{Ma}$ (Figure 3-15b), but their limited overlap with the concordia band suggests that their slightly younger ages may reflect minor $\mathrm{Pb}$ loss. Indeed, together with the remaining Campanian zircons they lie on a discordia chord with MSWD of 1.1 and upper intercept age very close to the age of the most concordant zircon, at $78.54 \pm 0.76 \mathrm{Ma}$ (Figure 3-15d). Therefore we consider the age of 78.27 $\pm 0.18 \mathrm{Ma}$ to be the best estimate of the crystallization age of the granodiorite.

Fifteen zircons were analyzed by LA-ICPMS (Figure 3-16a). Eleven grains form a coherent group at about $78 \mathrm{Ma}$ and three analyses detect Permian cores in Late Cretaceous zircons (Figure 3-16a, b). The crystallization age of $78.63+0.74-2.32$ Ma calculated with the TuffZircAge algorithm of ISOPLOT (Figure 3-16c) is similar to the ID-TIMS estimate for crystallization age of the rock $(78.27 \pm 0.18 \mathrm{Ma})$.

a

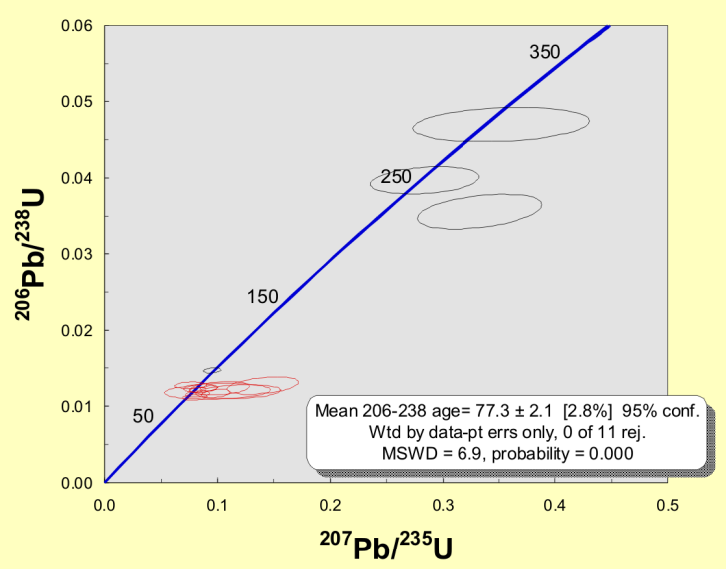

b

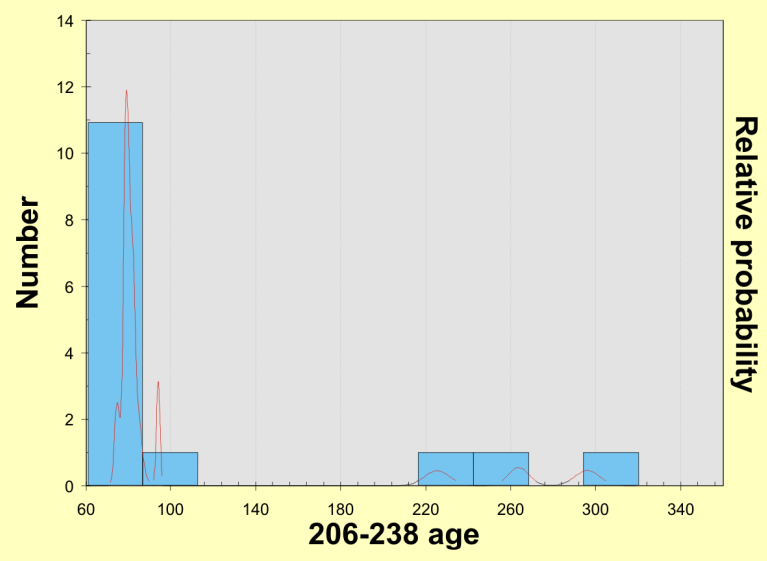

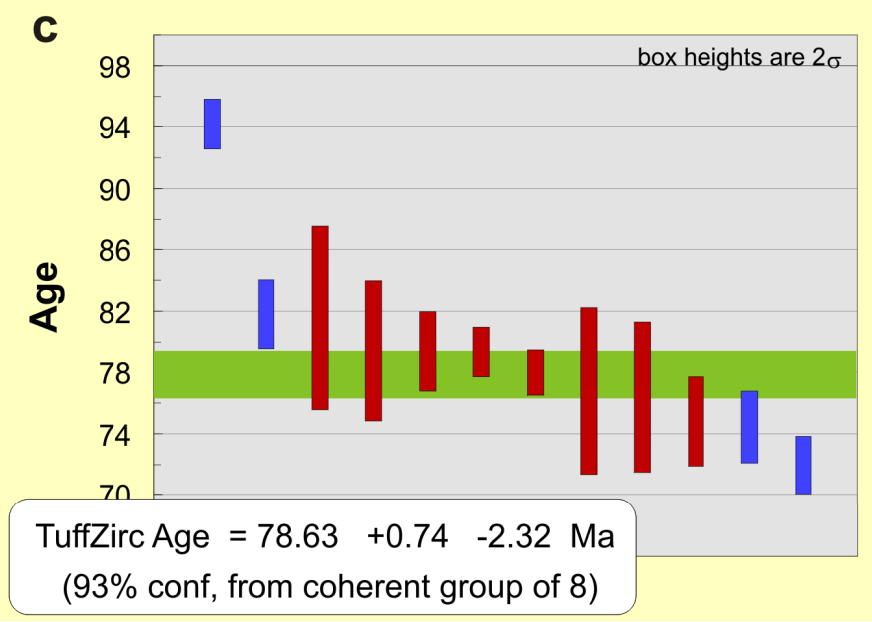

SG 030 - Latite, Southern Strandzha
Figure 3-16. Results from single zircon U-Pb LAICPMS dating for sample SG 028

This rock is from the southernmost

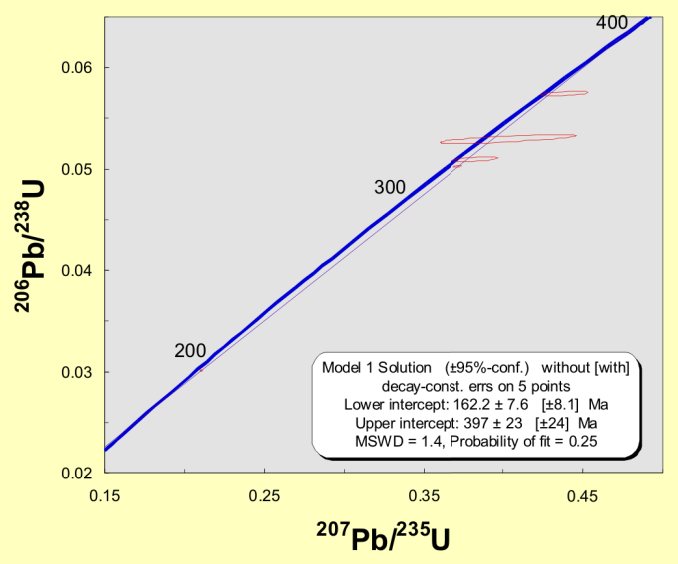
occurrence of basic/intermediate lavas in Eastern Srednogorie, south of Razdel village, and represents the only sizeable outcrop of volcanic rocks preserved in the Strandzha region. Five zircons grains were analyzed by ID-TIMS; three of them chemically abraded, the other two were not abraded. All grains are variably discordant and have ${ }^{206} \mathrm{~Pb} /{ }^{238} \mathrm{U}$ ages distinctly older than Late Cretaceous, some zircons overlap slightly the concordia band (Figure 3-17).

Figure 3-17. Results from single zircon U-Pb ID-TIMS dating for sample SG 030 
The discordance of chemically abraded zircons can be explained with the presence of older inherited cores. A model 1 discordia line calculated with all five points has an MSWD of 1.4 and upper intercept of $397 \pm 24 \mathrm{Ma}$. The lower intercept gives an age of 162.2 $\pm 8.1 \mathrm{Ma}$, suggesting that Devonian inherited cores were overgrown by variable amounts of Middle to Upper Jurassic rims.

\section{SG 032 - Basaltic dike, Gramatikovo pluton?}

The dike crosscuts the low-grade metamorphic rocks from the Strandzha allochtonous unit, south of the village of Gramatikovo. Three unabraded zircons analyzed by ID-TIMS have discordant ages (Figure 3-18). One grain with a ${ }^{206} \mathrm{~Pb} /{ }^{238} \mathrm{U}$ age of $85.31 \mathrm{Ma}$ indicates a possible Late Cretaceous event. The three zircons

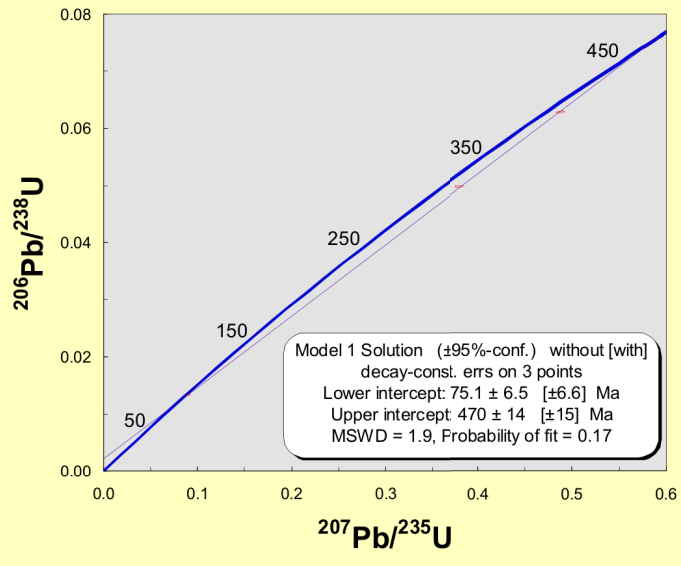

Figure 3-18. Results from single zircon U-Pb ID-TIMS dating for sample SG 032 form a discordia chord with lower intercept of 75.1 $\pm 6.6 \mathrm{Ma}$ and an upper intercept of $470 \pm 15 \mathrm{Ma}$ indicating an Ordovician magmatic event. The Late Cretaceous lower intercept is based on 3 points only (and only one of the Cretaceous) and therefore not considered a robust age estimate. Considering the proximity of Gramatikovo pluton and its $86 \mathrm{Ma}$ well defined crystallization age (see sample ST 25), it not unlikely that the studied dike is genetically related to the pluton and its single zircon poordefined concordia age of $85.23 \pm 3.6 \mathrm{Ma}$ at the $95 \%$ confidence level represents better the crystallization age of the dike than the lower intercept age. Additional analyses are needed to better constrain the crystallization age of the sample.

\section{SG 045 - Granite, Granitovo}

The sample is from a quarry near the village of Kamenna Reka. Four chemically abraded zircons were dated by ID-TIMS (Figure 3-19a). One zircon yields a concordant age of 79.66 $\pm 0.14 \mathrm{Ma}, 2$ sigma errors (Figure 3-19b), which is just slightly younger than the $79.94 \pm 0.14 \mathrm{Ma}$ age of the granodiorite phase from the same pluton (see sample AvQ 048). A second zircon with almost identical ${ }^{206} \mathrm{~Pb} /{ }^{238} \mathrm{U}$ age is discordant, having a slightly older ${ }^{207} \mathrm{~Pb} /{ }^{235} \mathrm{U}$ age of $80.21 \mathrm{Ma}$. Two discordant zircons with clearly older ${ }^{206} \mathrm{~Pb} /{ }^{238} \mathrm{U}$ ages the Late Cretaceous concordant zircon lie on a chord with upper intercept of $246 \pm 52 \mathrm{Ma}$ suggesting the presence of Permian inherited cores.
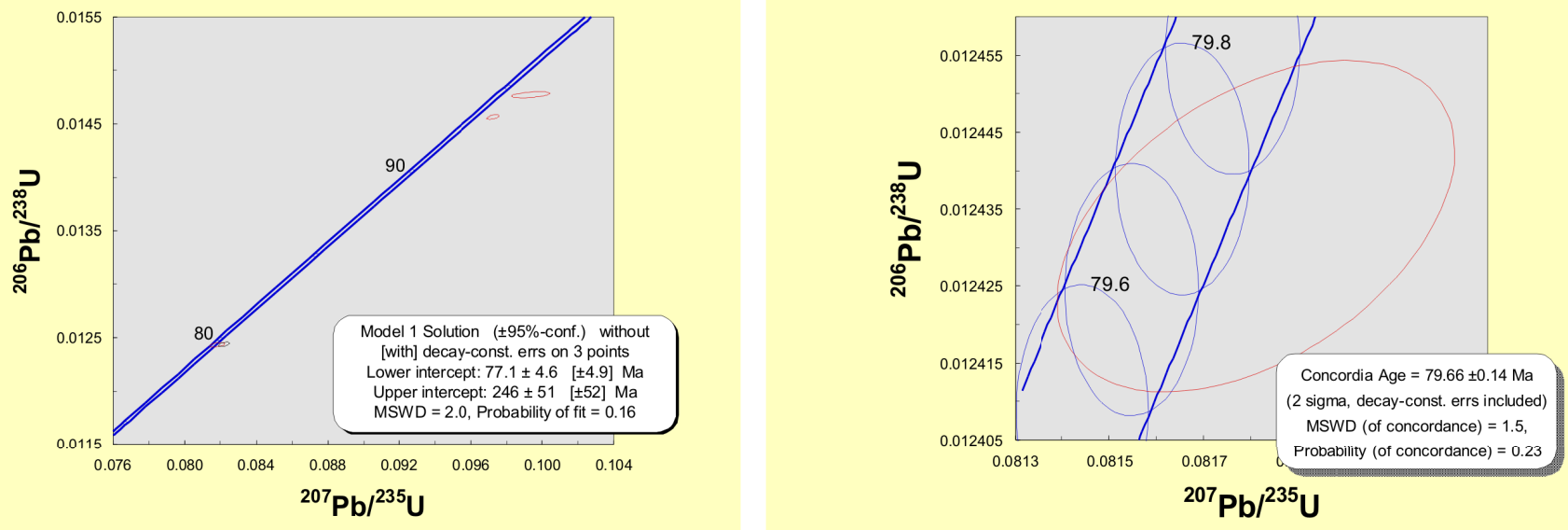

Figure 3-19. Results from single zircon U-PB ID-TIMS dating for sample SG 045 


\section{SG 047 - Gneiss-granite, Oman-Fakya}

The sample, taken between the villages of Dennitsa and Oman, is representative of the frame into which the Late Cretaceous Oman-Fakya pluton intruded. Ten zircon grains dated by U-Pb LA-ICPMS (Figure 3-20a-d) have a Permian/ Carboniferous concordant age of $293.8 \pm 7.6 \mathrm{Ma}$ at the $95 \%$ confidence limit. One older grain is concordant at $450 \mathrm{Ma}$.

a
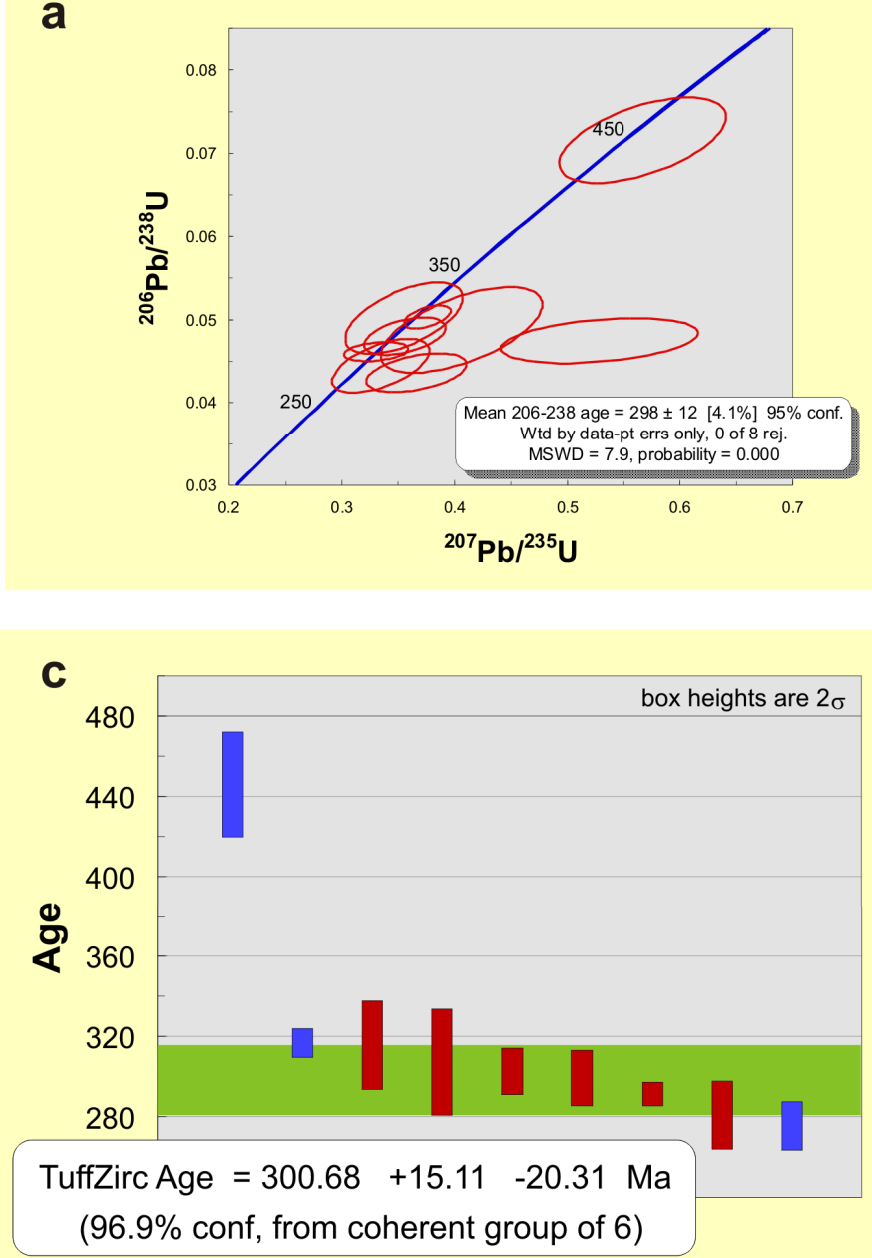

b

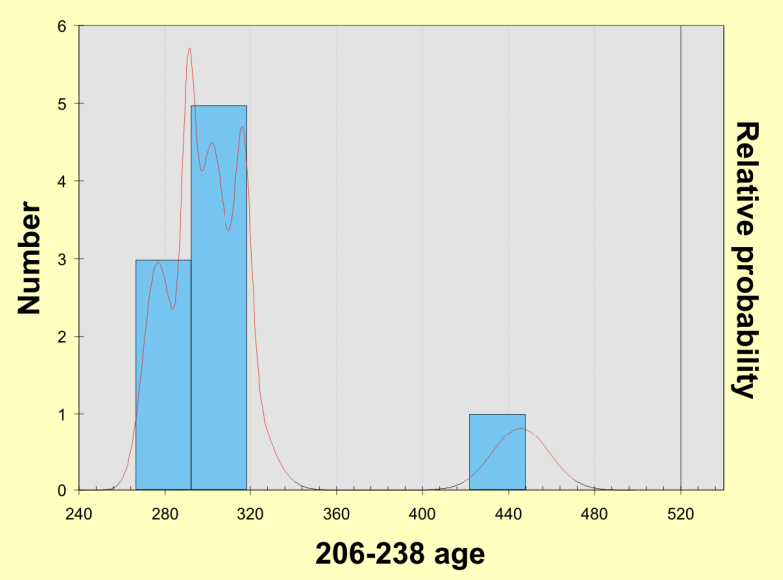

d

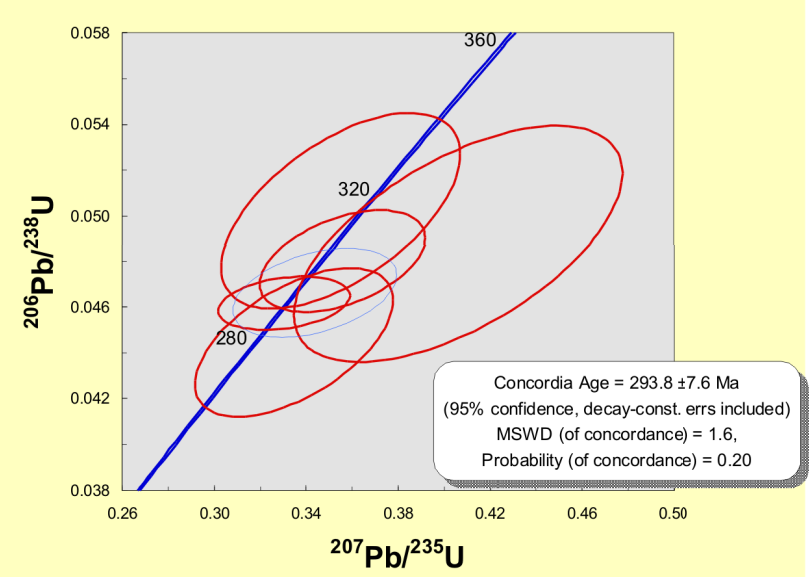

Figure 3-20. Results from single zircon U-Pb LA-ICPMS dating for sample SG 047

\section{SG 051 - hyd rothermally altered granite, Granitovo}

Six unabraded and air abraded for two hours zircon grains dated by ID-TIMS all show disturbed U-Pb systematics (Figure 3-21a). The youngest zircon has a ${ }^{206} \mathrm{~Pb} /{ }^{238} \mathrm{U}$ age of $76.54 \pm 1.01 \mathrm{Ma}$, with an imprecise ${ }^{207} \mathrm{~Pb} /{ }^{235} \mathrm{U}$ age. Four of the remaining zircons lie on a discordia line with an MSWD $=1.5$ and upper intercept at $268 \pm 37 \mathrm{Ma}$, pointing towards a possible Permian age and recent $\mathrm{Pb}$ loss (lower intercept close to present). Sixteen LA-ICPMS analyses have grossly disturbed U-Pb systematics (Figure 3-22). No meaningful age could be extracted from this population. 
a

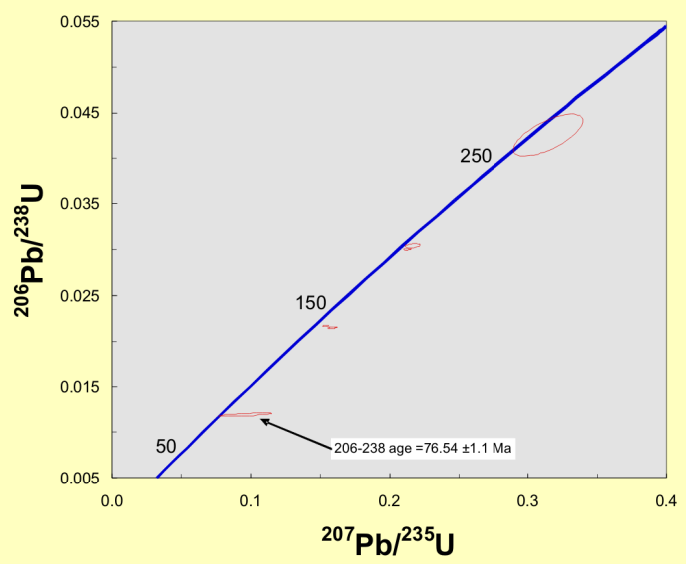

b

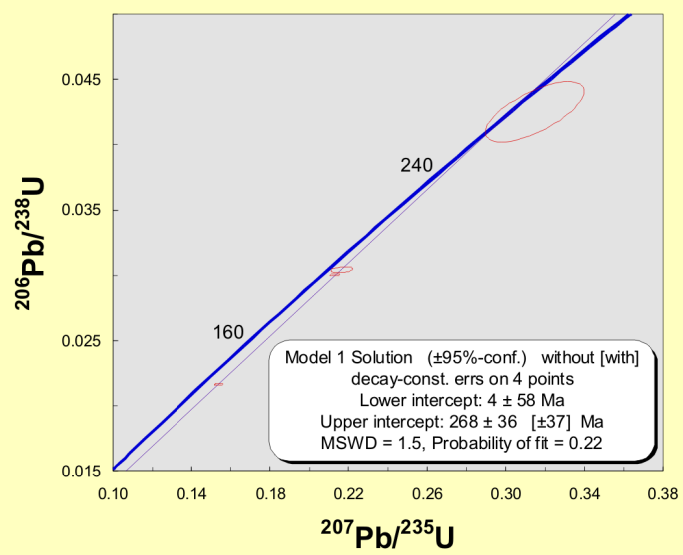

Figure 3-21. Results from single zircon U-Pb ID-TIMS dating for sample SG 051

a

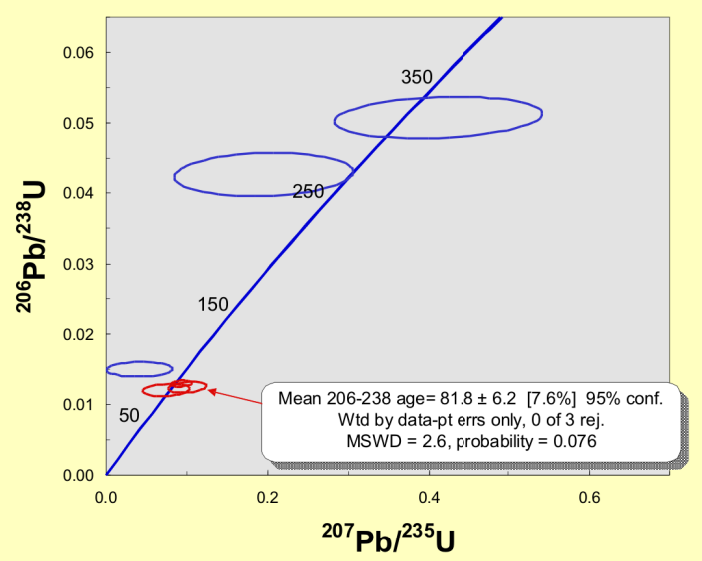

C

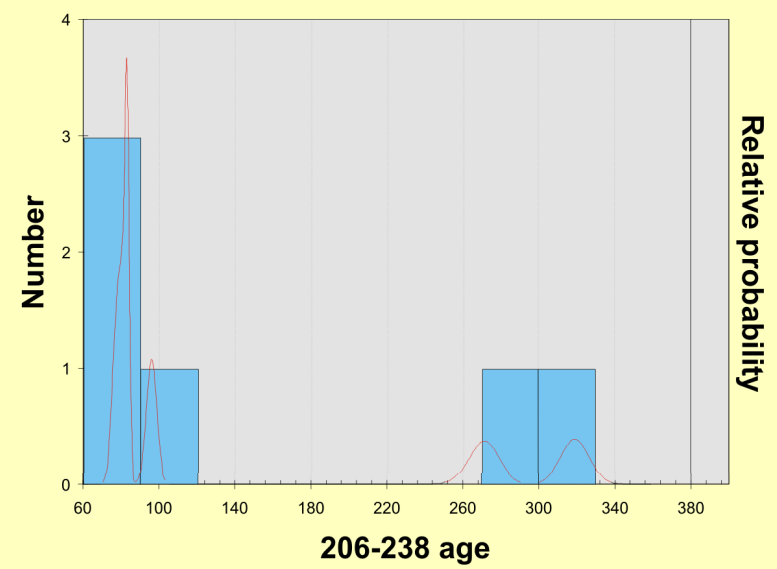

b

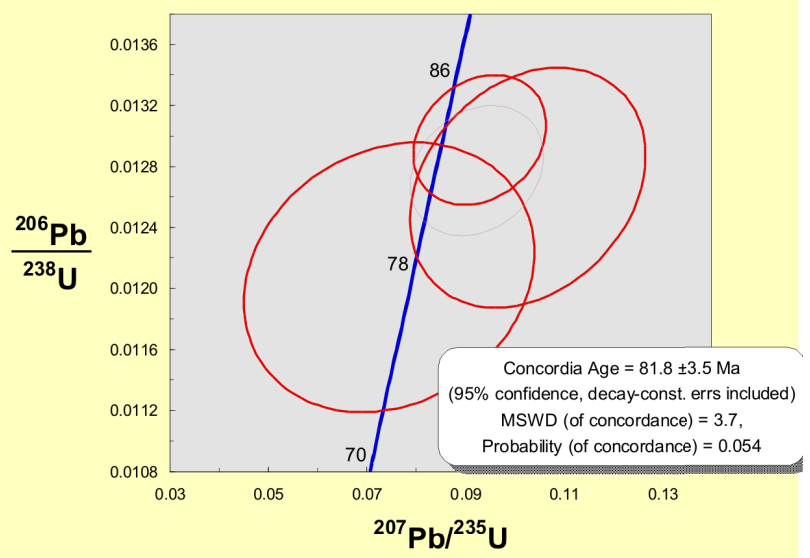

d

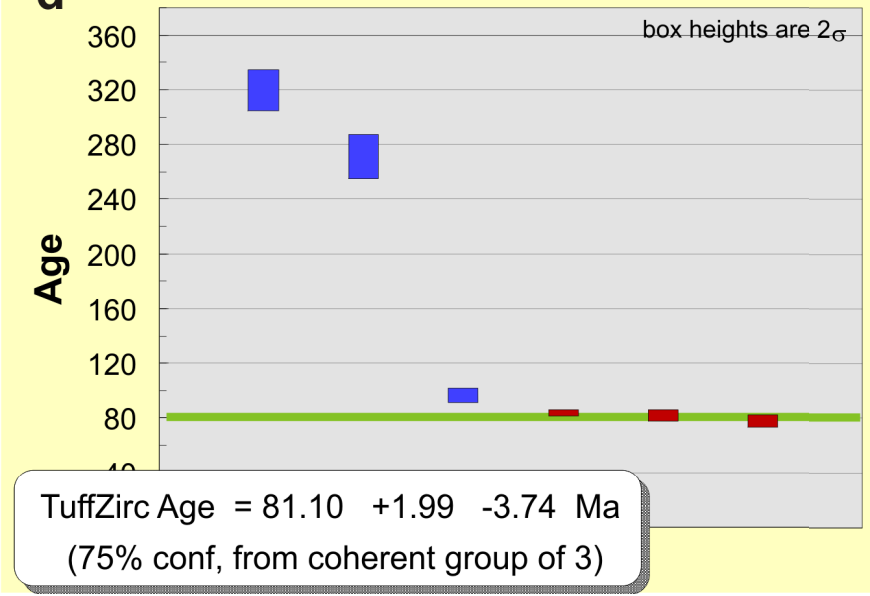

Figure 3-22. Results from single zircon U-Pb LA-ICPMS dating for sample SG 051

\section{SG 052 - Aplitic dike, Monastery Heights}

Three zircons and one monazite were analyzed by ID-TIMS (Figure 3-23a). The error ellipses of two zircons overlap, yielding a concordant age of $78.83 \pm 0.17 \mathrm{Ma}, 2$ sigma error (Figure 3-23b). The monazite is concordant at $74.75 \pm 0.20 \mathrm{Ma}$, while the third zircon is discordant, with unclear relations to the other grains.

Additional six zircons were dated by LA-ICPMS (Figure 3-24a). The unmix ages algorithm of ISOPLOT yields a ${ }^{206} \mathrm{~Pb} /{ }^{238} \mathrm{U}$ age of $78.76 \pm 1.7 \mathrm{Ma}$ for five zircons from the population (Figure 3-24b). One grains has a concordant Carboniferous age. 
a

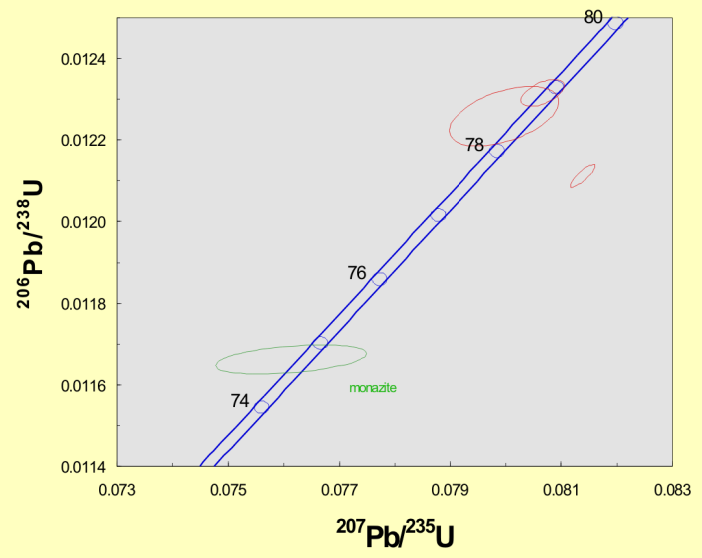

b

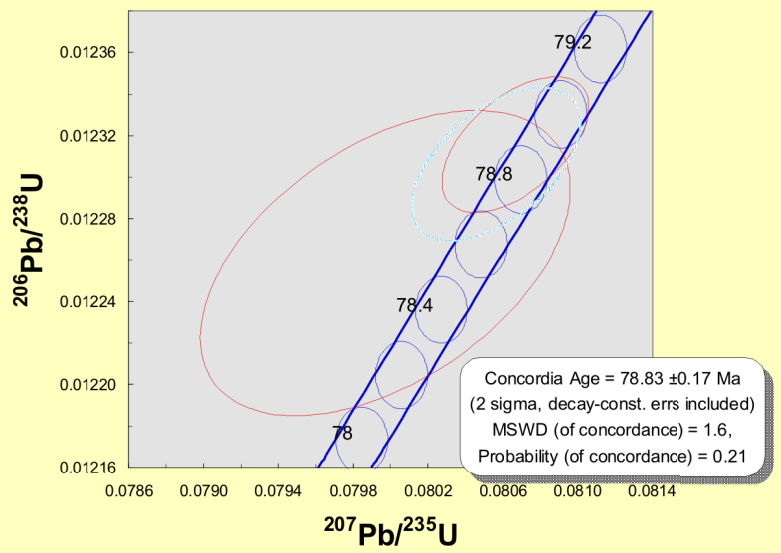

Figure 3-23. Results from single zircon U-Pb ID-TIMS dating for sample SG 052
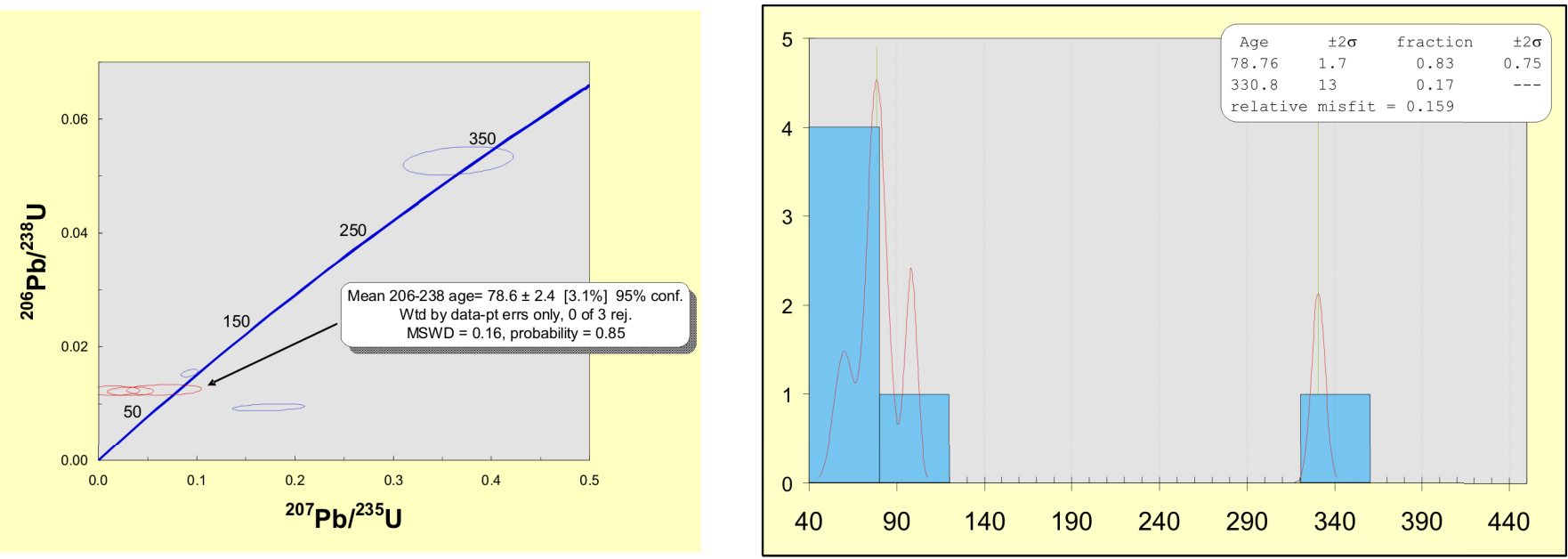

Figure 3-24. Results from single zircon U-Pb LA-ICPMS dating for sample SG 052

\section{SG 053 - Gabbro, Chernozem-Razdel}

Eight zircons were analyzed by U-Pb LA-ICPMS (Figure 3-25a). The zircon age extractor algorithm gives an age of 79.91 +1.07 -3.09 Ma (Figure 3-25b). Three grains have older ${ }^{206} \mathrm{~Pb} /{ }^{238} \mathrm{U}$ ages of 120,276 and $396 \mathrm{Ma}$.

a

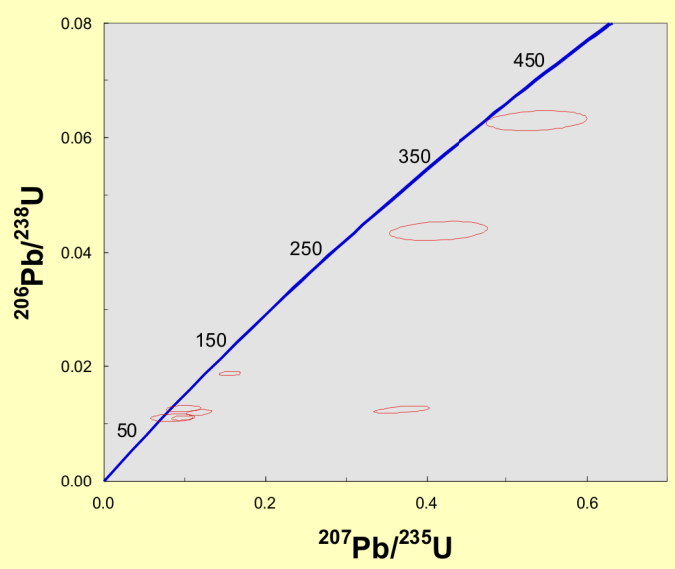

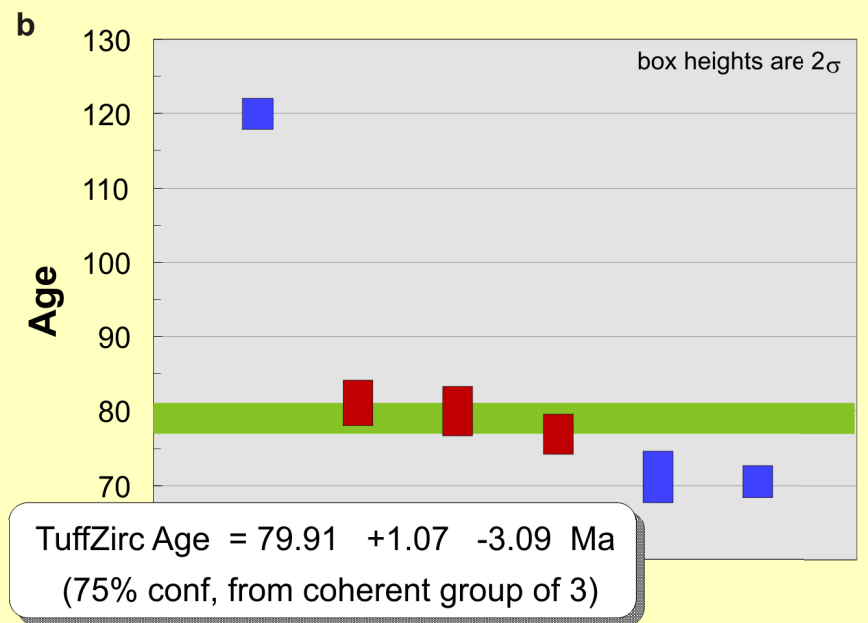

Figure 3-25. Results from single zircon U-Pb LA-ICPMS dating for sample SG 053 


\section{SG 057- Gabbro-diorite, southern Strandzha}

Six grains were analyzed by ID-TIMS, five air abraded for 3 hours and one grain air abraded for 6 hours. A wide spread of ages is observed (Figure 3-26a) and crystallization oag of the rock could not be determined. Three grains are concordant within their errors at 138, 291 and $433 \mathrm{Ma}$ (Figure 3-26 b, c, d). An additional grain is concordant at $216 \mathrm{Ma}$, but with a high error on the ${ }^{207} \mathrm{~Pb} /{ }^{235} \mathrm{U}$ ratio. Together with two other grains it lies on a discordia line with a $\mathrm{MSWD}=2$, lower intercept at $111.5 \pm 5.2 \mathrm{Ma}$ and upper intercept at $441.8 \pm 6.1 \mathrm{Ma}$ (Figure 3-26e). One discordant grain has a Late Cretaceous ${ }^{206} \mathrm{~Pb} /{ }^{238} \mathrm{U}$ age but this does not necessarily imply a Late Cretaceous age of the sample, because the analysis lies on the line of recent $\mathrm{Pb}$ loss of the 138 Ma old concordant zircon.

a

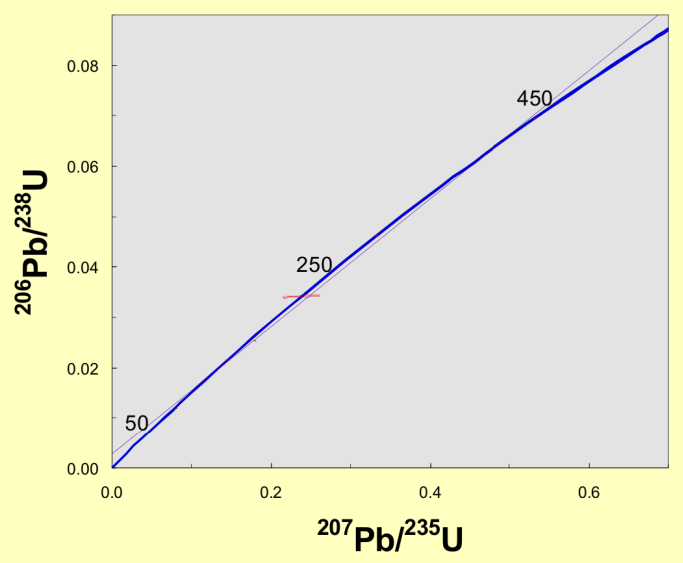

C

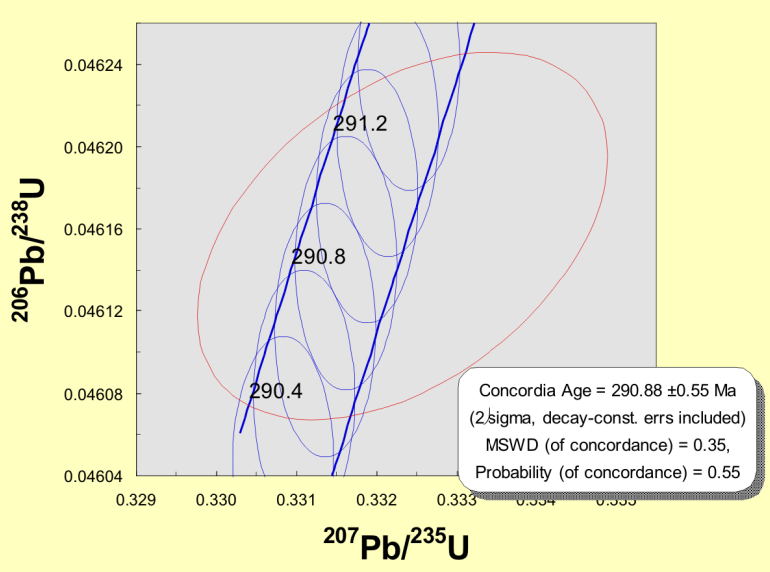

b

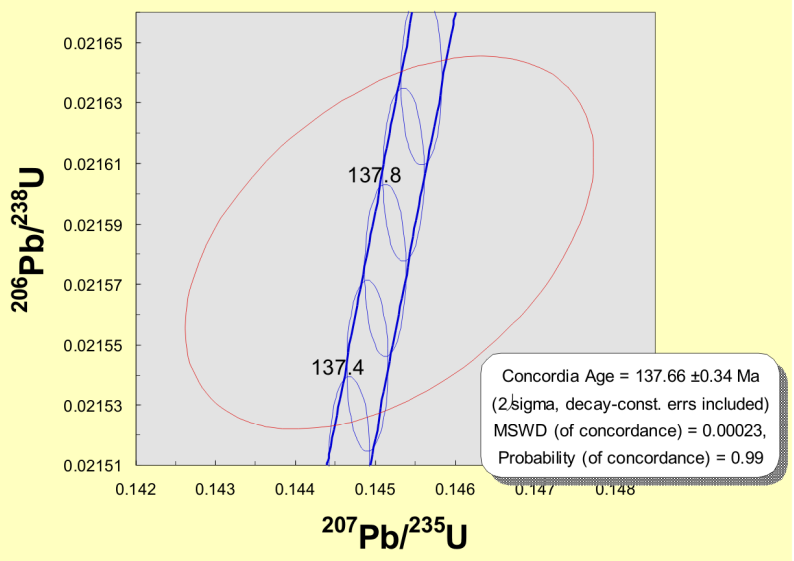

d

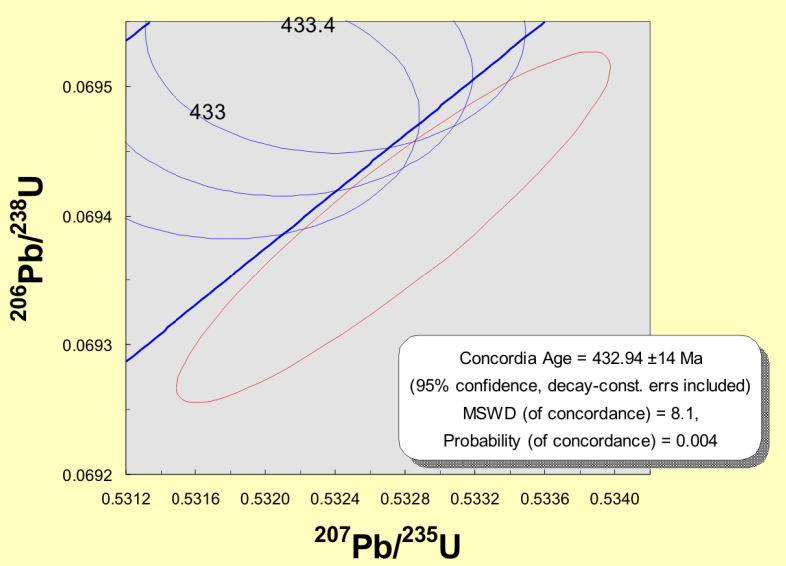

e

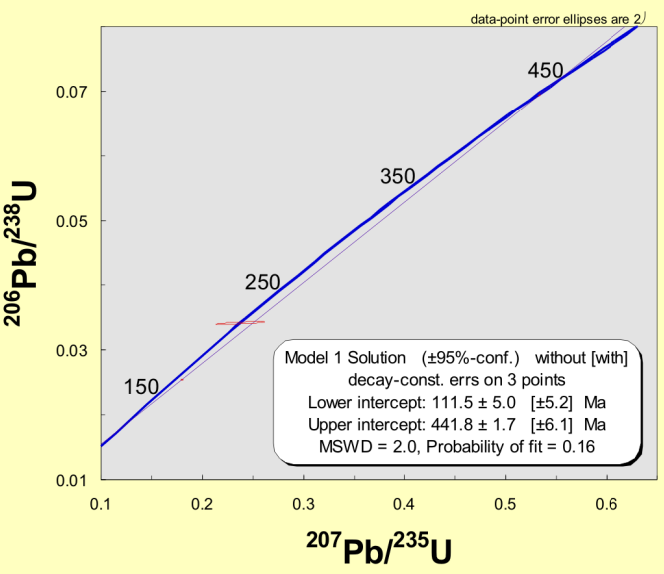

Figure 3-26. Results from single zircon U-Pb ID-TIMS dating for sample SG 057 
LA-ICPMS U-Pb ages of 11 zircons from this sample also show wide scatter (Figure 3-27) and do not resolve the age of the rock. Late Cretaceous ages are not detected by the LA dating; one grain has a ${ }^{206} \mathrm{~Pb} /{ }^{238} \mathrm{U}$ age of $47 \mathrm{Ma}$ with a slight reverse discordance. Four grains give a weighted average ${ }^{206} \mathrm{~Pb} /{ }^{238} \mathrm{U}$ age of $134 \pm 13$ $\mathrm{Ma}$ at the $95 \%$ confidence level and high scatter $(\mathrm{MSWD}=27)$. More analyses are needed for confident age determination of this sample.

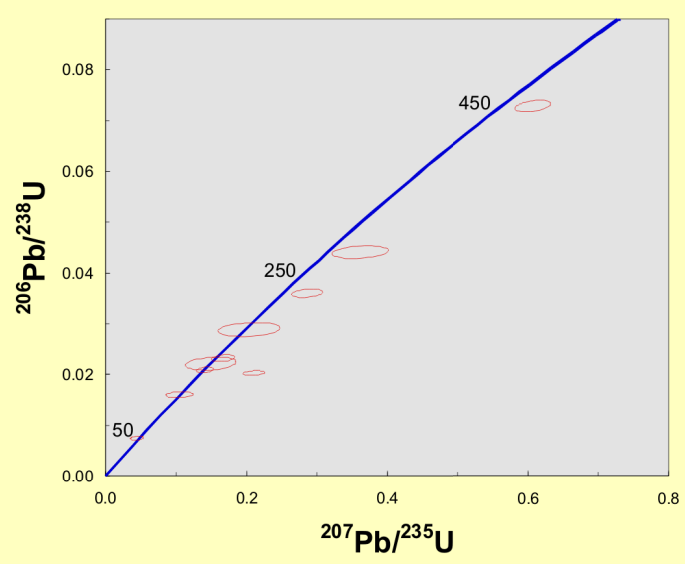

Figure 3-27. Results from single zircon U-Pb LA-ICPMS dating for sample SG 057

\section{SG 059- Gabbro, Zheljazkovo}

Four zircons dated by ID-TIMS are situated at or close to the concordia, and three of them yield a Carboniferous concordant age of 301.26 $\pm 0.97 \mathrm{Ma}, 2$ sigma errors (Figure 3-28).

a

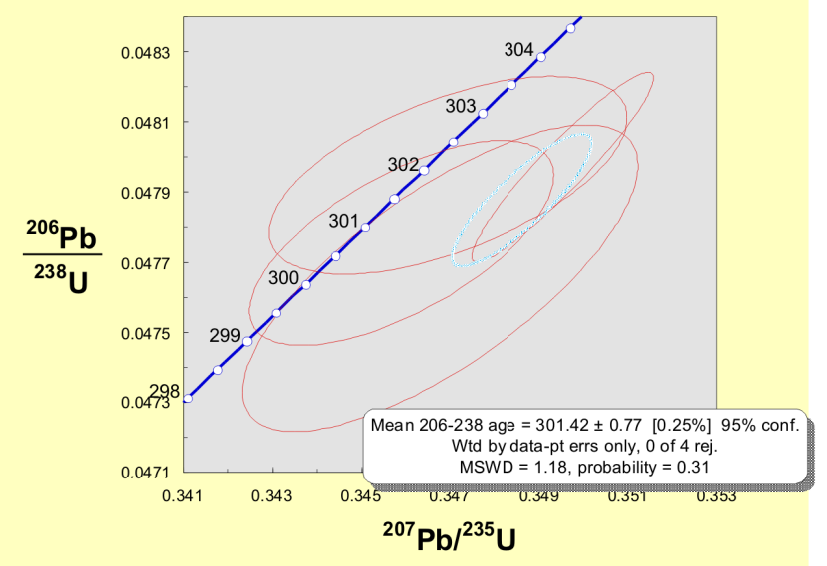

b

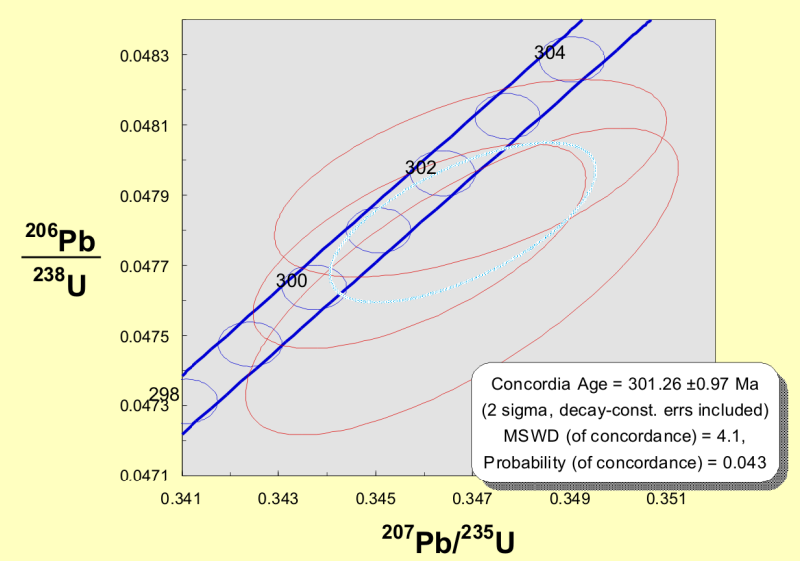

Figure 3-28. Results from single zircon U-Pb ID-TIMS dating for sample SG 059

\section{SG 070 - Gneiss-granite, Monastery Heights}

This sample is taken as representative for the basement rocks, into which the Late Cretaceous Monastery Heights pluton was intruded. Eleven zircons dated by LA-ICPMS are presented on Figure 3-29. Most grains have coherent ${ }^{206} \mathrm{~Pb} /{ }^{238} \mathrm{U}$ ages of about $270 \mathrm{Ma}$ (Figure 3-29b, c.). Five zircons overlap within their assigned errors with the concordia curve and yield a concordia age of 274.1 $\pm 4.5 \mathrm{Ma}$, which is considered to represent the crystallization age of the granite (Figure 3-29d). 
a
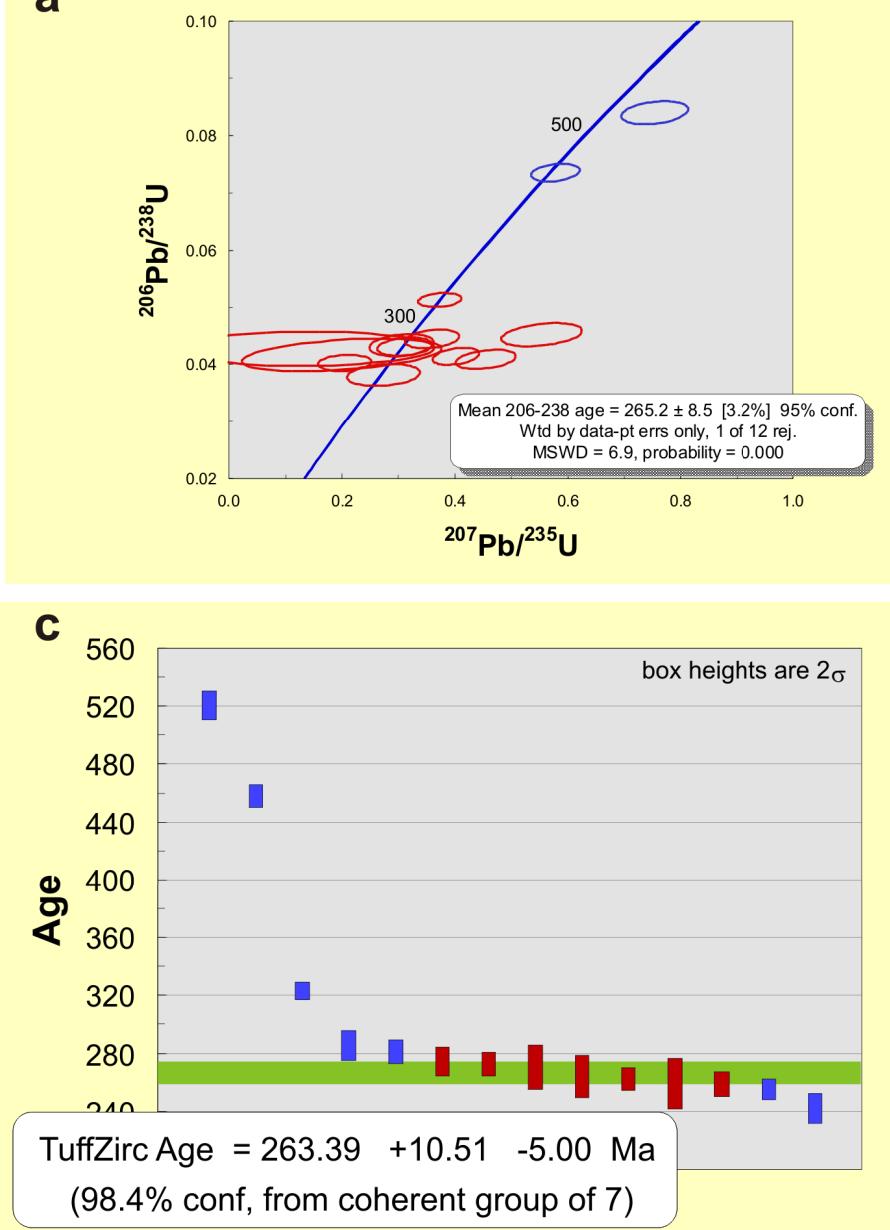

b

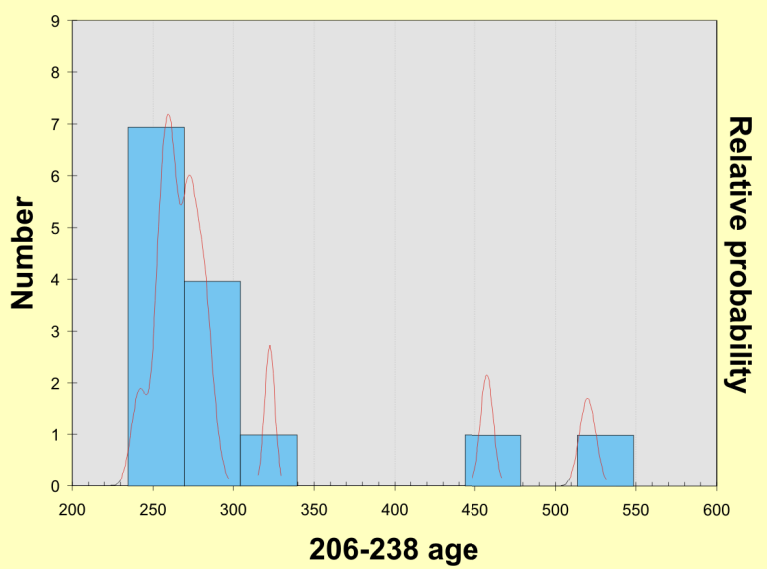

d

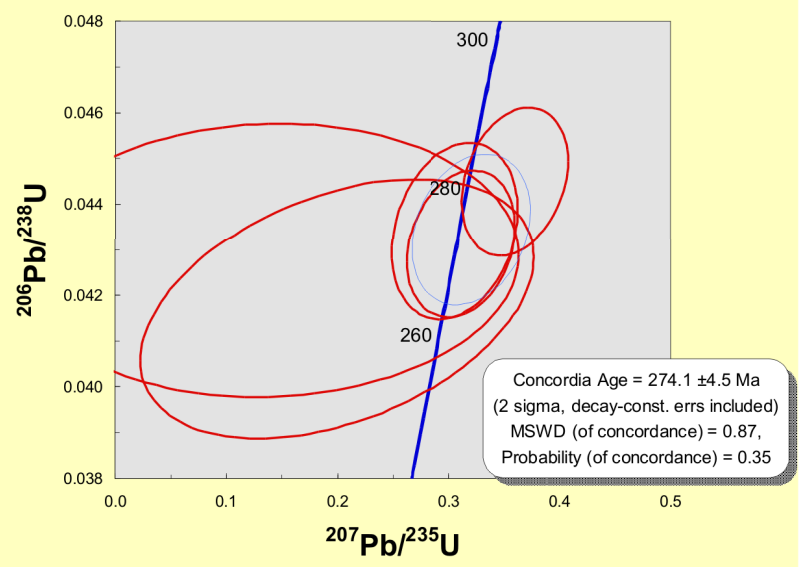

Figure 3-29. Results from single zircon U-Pb LA-ICPMS dating for sample SG 070

\section{ST 25 - Gabbro, Gramatikovo}

Four zircons analyzed by ID-TIMS yield a concordia age of $86.84 \pm 0.29 \mathrm{Ma}, 95 \%$ confidence limits, and a slightly older weighted average ${ }^{206} \mathrm{~Pb} /{ }^{238} \mathrm{U}$ age of $87.02 \pm 0.29$ (Figure 3-30). All grains have rather low ${ }^{206} \mathrm{~Pb}^{*} / 204 \mathrm{~Pb}$ ratios from 45 to 70 , which indicates a large proportion of common $\mathrm{Pb}$. Ages were calculated with an increased blank proportion of $6 \mathrm{pg} / \mathrm{g}$, and the zircon with highest ${ }^{206} \mathrm{~Pb}^{*} /{ }^{204} \mathrm{~Pb}$ has the lowest ${ }^{206} \mathrm{~Pb} /{ }^{238} \mathrm{U}$ age which suggests that the concordia age is more representative for the age of the rock compared to the weighted average ${ }^{206} \mathrm{~Pb} /{ }^{238} \mathrm{U}$ age.

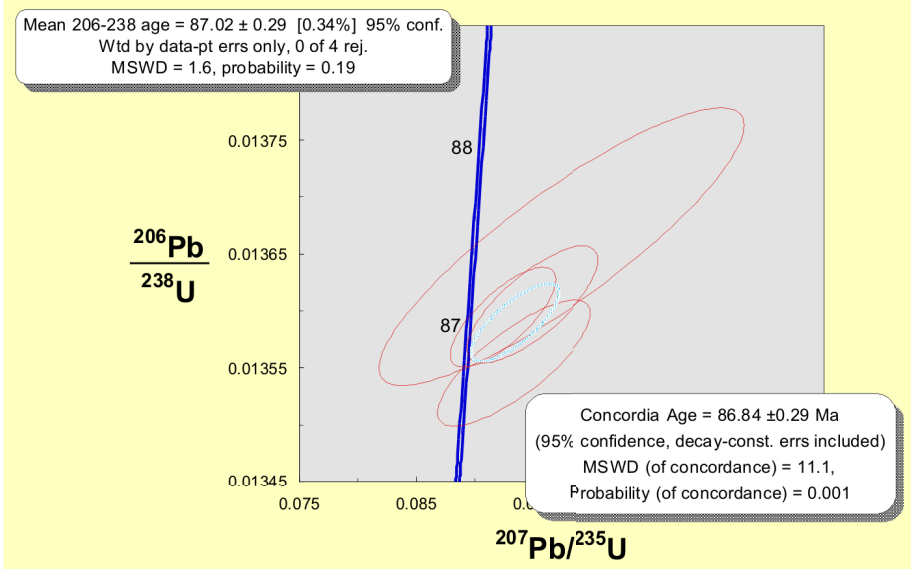

Additional five zircon and four sphene grains were dated by LA-ICPMS (Figure 3-31a). Four zircons yield a concordia age of $87.28 \pm 1.6$ Ma (Figure 3-31b), in good agreement with the IDTIMS age. The sphenes are largely discordant, even after applying ${ }^{204} \mathrm{~Pb}$ correction.

Figure 3-30. Results from single zircon U-Pb ID-TIMS dating for sample ST 25 
a

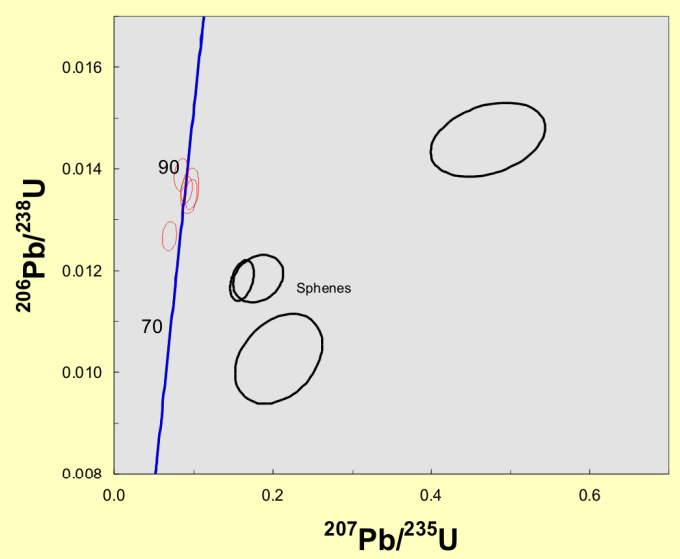

b

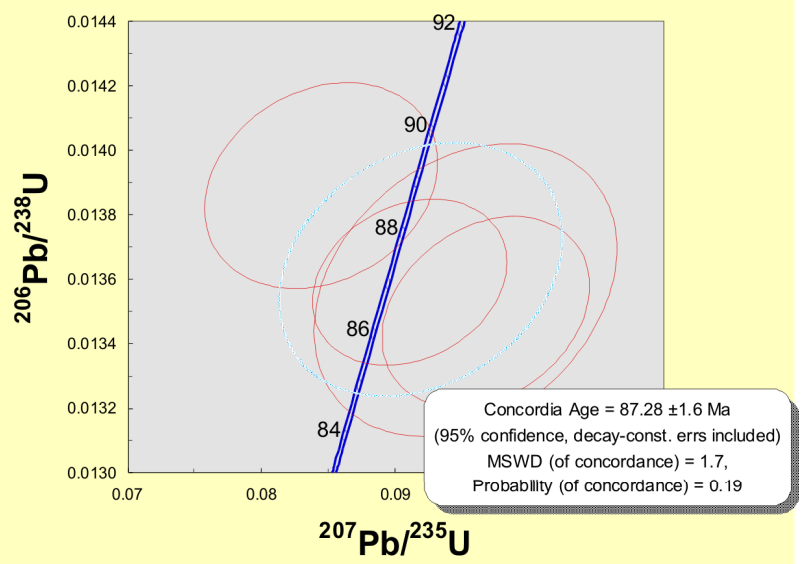

Figure 3-31. Results from single zircon U-PB LA-ICPMS dating for sample ST 25

\subsection{YAMBOL-BURGAS region}

\section{AvQ 052 - Monzo-syenite, Rossen}

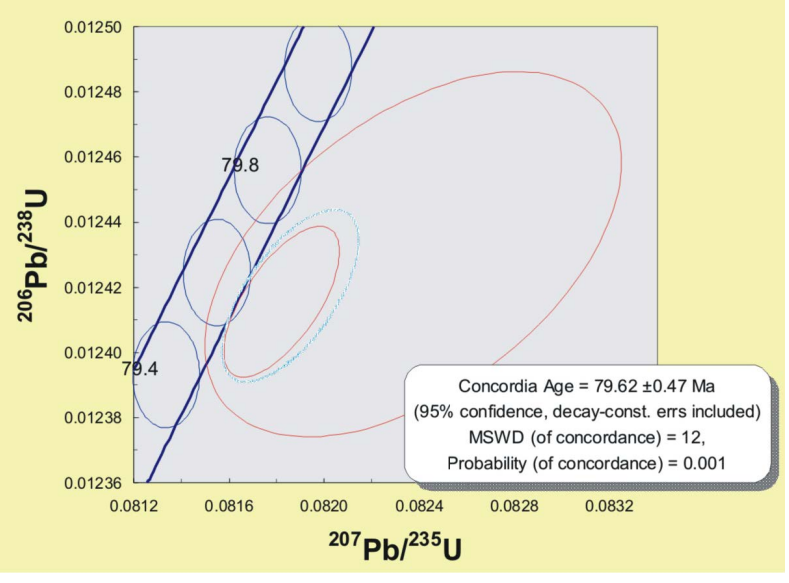

This monzo-syenite from Rossen volcanointrusive center is taken from the quarry near the village of Chernomoretz. The two zircons analyzed by U-Pb ID-TIMS (Figure 3-32) yield a Late Cretaceous concordant age of $79.62 \pm 0.47$ $\mathrm{Ma}(95 \%$ confidence level interval). Additional analyses are needed to better constrain the crystallization age.

Figure 3-32. Results from single zircon U-Pb ID-TIMS dating for sample AvQ 052

\section{AvQ 054 - Amphibole gabbro, Izgrev}

The sample was collected in the quarry of Izgrev pluton. Five zircon grains analyzed by ID-TIMS have concordant Late Cretaceous ages (Figure 3-33). Four zircons are concordant at $81.27 \pm 0.17 \mathrm{Ma}$; this age is interpreted to be the crystallization age of the rock. One grain has a ${ }^{206} \mathrm{~Pb} /{ }^{238} \mathrm{U}$ age slightly older than the four concordand zircons, probably due to incorporation of minor inherited component. The weighted average ${ }^{206} \mathrm{~Pb} /{ }^{238} \mathrm{U}$ age of all five zircons is $81.64 \pm 0.64 \mathrm{Ma}$, with a MSWD value of 8.1 . Only two prismatic grains were analyzed by LA ICPMS. Although this is insufficient for age calculation, they do have a Late Cretaceous ${ }^{206} \mathrm{~Pb} /{ }^{238} \mathrm{U}$ ages. 
a

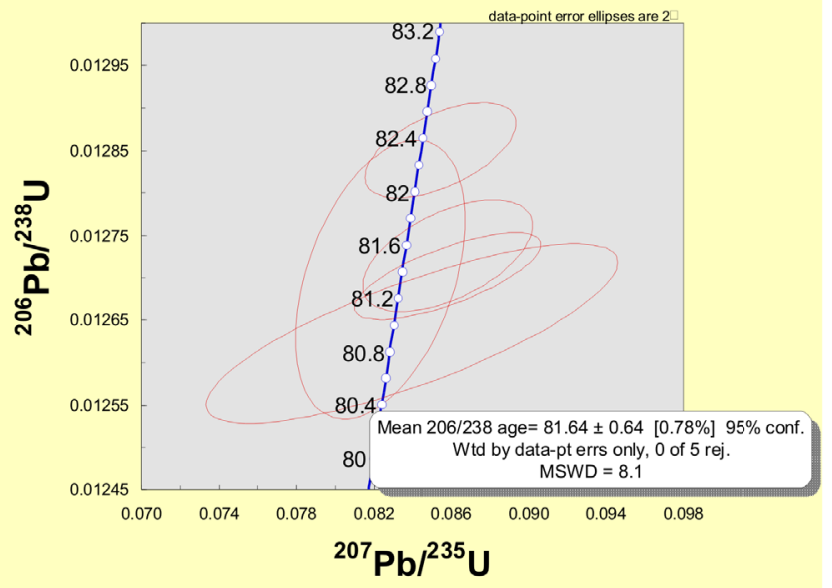

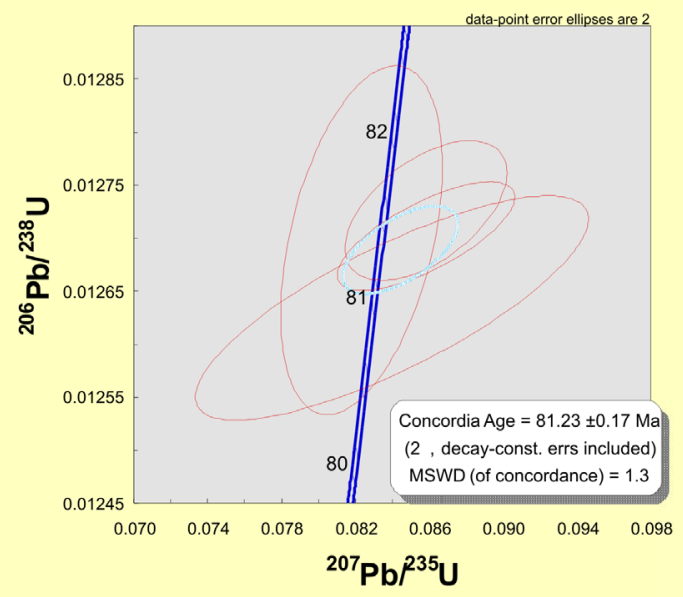

Figure 3-33. Results from single zircon U-Pb ID-TIMS dating for sample AvQ 054

\section{AvQ 055 - Amph gabbro, Izgrev}

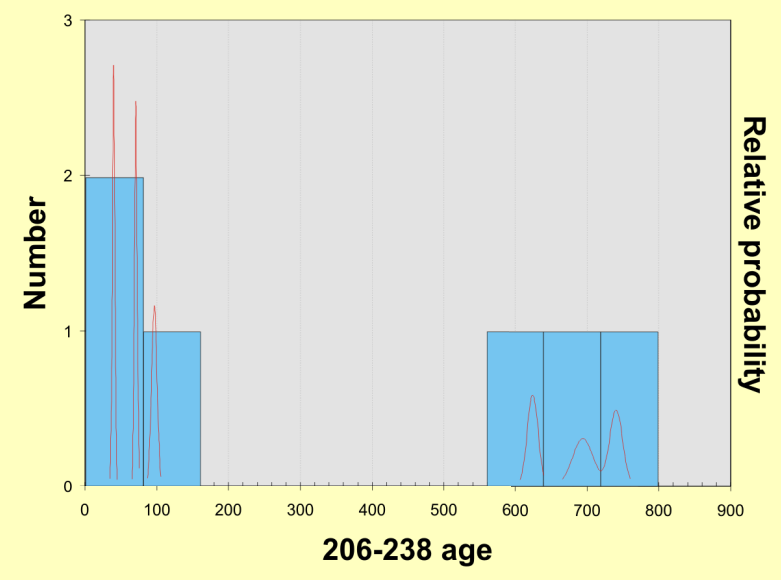

The sample is taken close to the locality where AvQ 054 is sampled; it represents a more finer-grained variety of the same rock as AvQ 054. Six zircons analyzed by LA-ICPMS are variably discordant. The relative probability distribution of the ${ }^{206} \mathrm{~Pb} /{ }^{238} \mathrm{U}$ ages indicates an old inherited age within 650-750 Ma (Figure 3-34). Three zircons have younger ages with limited overlap between two of them. Additional analyses are needed for age calculation. The TIMS crystallization age of $81.27 \pm 0.17 \mathrm{Ma}$ of sample AvQ 054 is most likely representative also for the finergrained variety in AvQ 055 .

Figure 3-34. Results from single zircon U-Pb LA-ICPMS dating for sample AvQ 055

\section{AvQ 057 - Olivine-Gabbro, Izgrev}

This sample is from Izgrev pluton, and was collected just outside of the quarry where AvQ 054 and AvQ 055 were sampled. We analyzed 13 zircons using conventional U-Pb ID-TIMS. The gabbro has a complicated inheritance pattern, with most of the points being concordant or lying close to the concordia curve (Figure 3-35a). The resulting precise zircon ages cover a wide range from ca. 80 to $460 \mathrm{Ma}$, and there is also an indication for a possible Mesoproterozoic magmatic event. The concordia age of the two youngest zircons at $79.93 \pm 0.22 \mathrm{Ma}$ (Figure 3-35b) is considered as the crystallization age of the rock.

The most prominent group of inherited zircons is clustered around $460 \mathrm{Ma}$ and four of them lie on a discordia line with upper intercept age of $464 \pm 14 \mathrm{Ma}$ (Figure 3-35c). The uppermost zircon on Figure 3-35c lies almost entirely within the concordia band and yields a well-defined Ordovician concordia age of 462.2 $\pm 1.2 \mathrm{Ma}$ (Figure 3-35f). The remaining zircons on Figure 3-35c have slightly younger U-Pb ages probably reflecting minor $\mathrm{Pb}$ loss. Two zircons have older ${ }^{206} \mathrm{~Pb} /{ }^{238} \mathrm{U}$ and ${ }^{207} \mathrm{~Pb} /{ }^{235} \mathrm{U}$ ages and together with the Ordovician concordant zircon form a discordia line with lower intercept in the Ordovician, and an upper intercept at 1353 \pm Ma (Figure 3-35d). The two older zircons probably crystallized in the Mesoproterozoic and were later overgrown by Ordovician rims. Two long prismatic grains are concordant at $403.63 \pm 0.86 \mathrm{Ma}$, indicative of a Lower Devonian magmatic event (Figure 3-35e). Additional two inherited zircon concordant ages can be recognized at $160.11 \pm 0.63 \mathrm{Ma}$ and $279.61 \pm 0.70 \mathrm{Ma}$ (Figure 3-35g,h). The relatively large errors on the Jurassic and Permian single zircons questions their concordance and their geologic meaning. However, part of 
the age data obtained from six LA ICPMS analyses (only single age domains) confirm a Jurassic event at 159 $\pm 2.6 \mathrm{Ma}$ (Figure 3-36). The LA-ICPMS dating also reveal 417.9 $\pm 8.5 \mathrm{Ma}$ age(Figure 3-36) which is close to the ID-TIMS well defined Devonian age of inherited grains.

In summary, the Izgrev gabbro AvQ 057 that crystallized in the Late Cretaceous carries evidence for a broad range of age events within the basement rocks of Izgrev pluton: Jurassic, Permian, Devonian, Ordovician and possibly Mesoproterozoic.

a

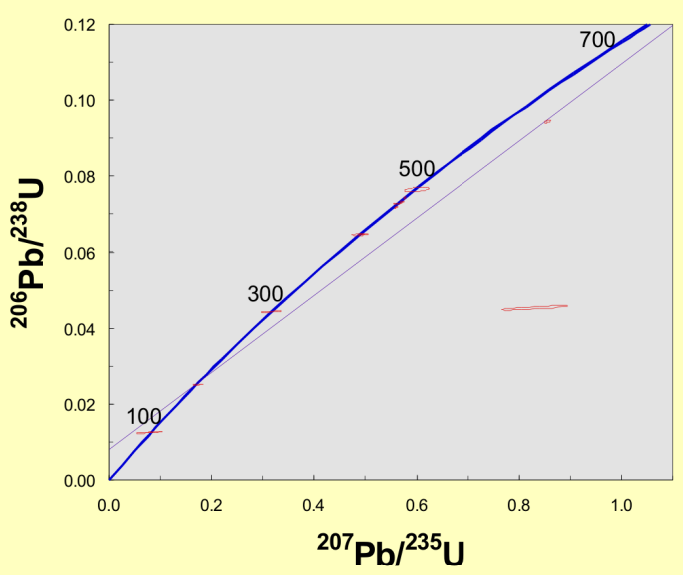

c

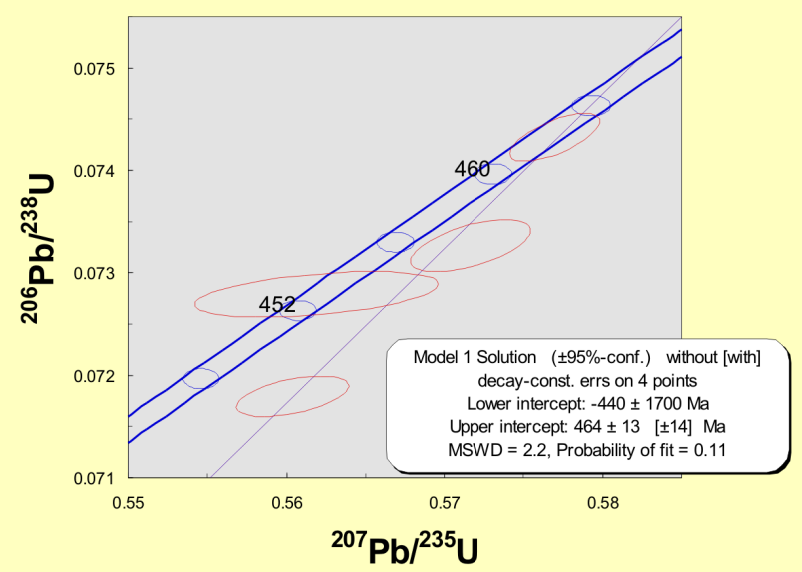

e

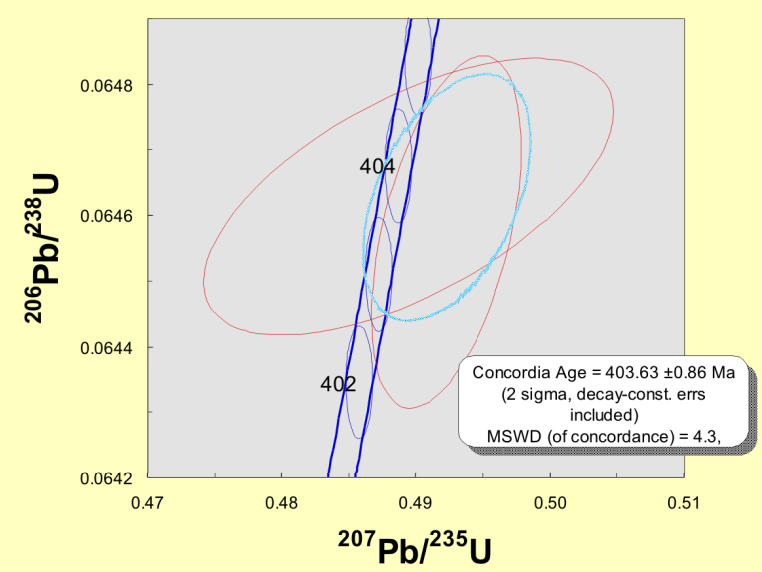

b

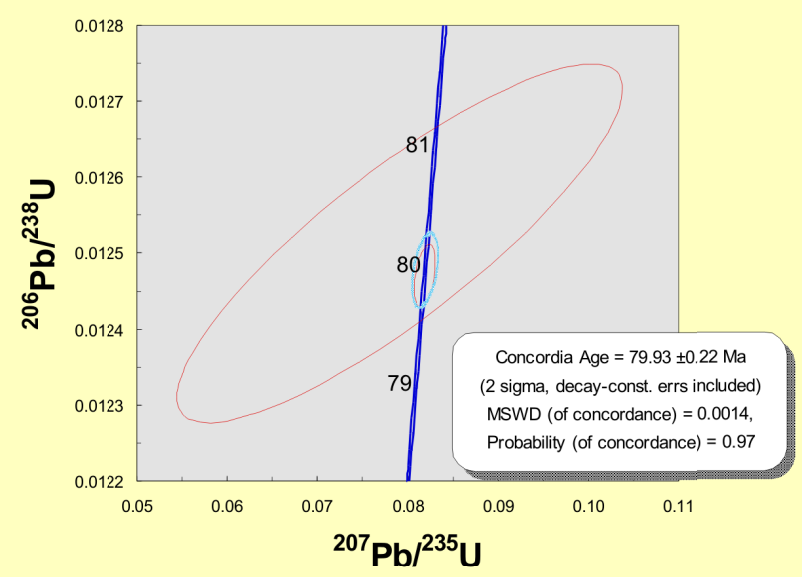

d

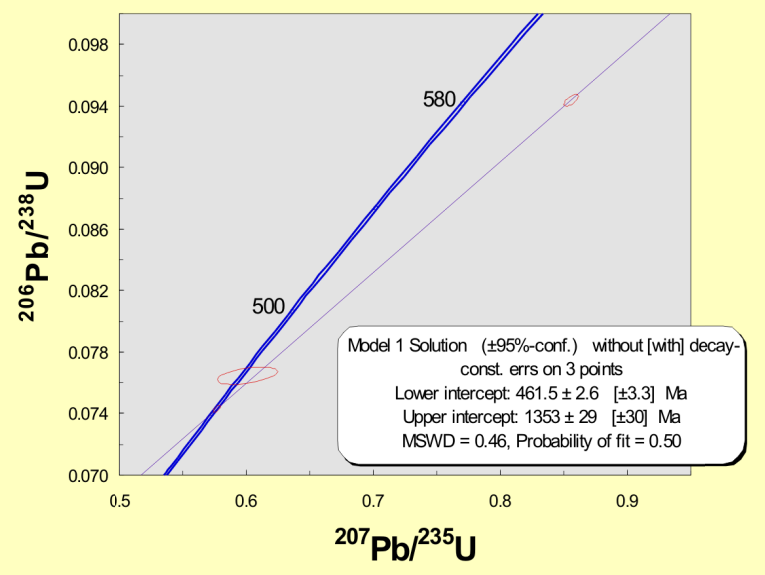

f

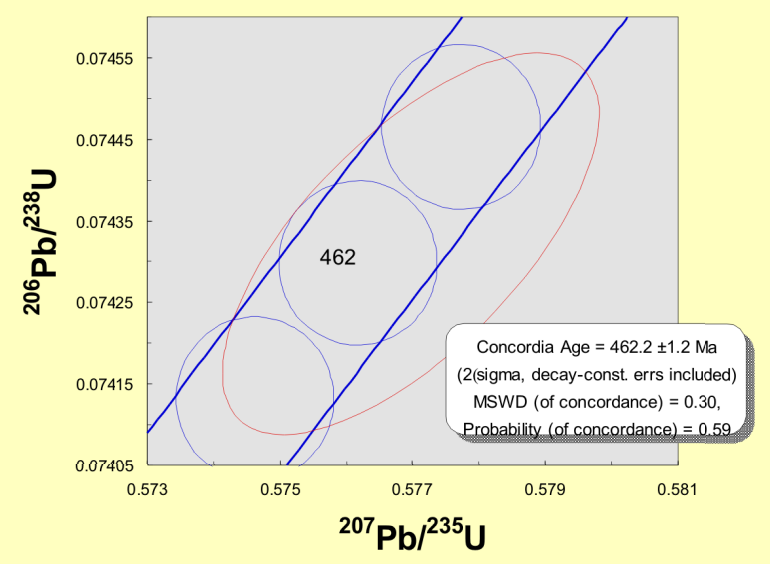

Figure 3-35. Results from single zircon U-Pb ID-TIMS dating for sample AvQ 057 
g

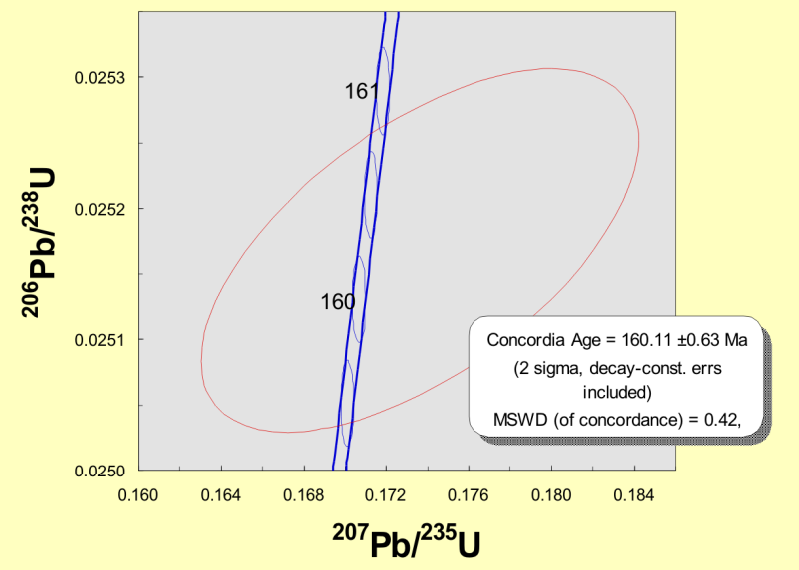

h

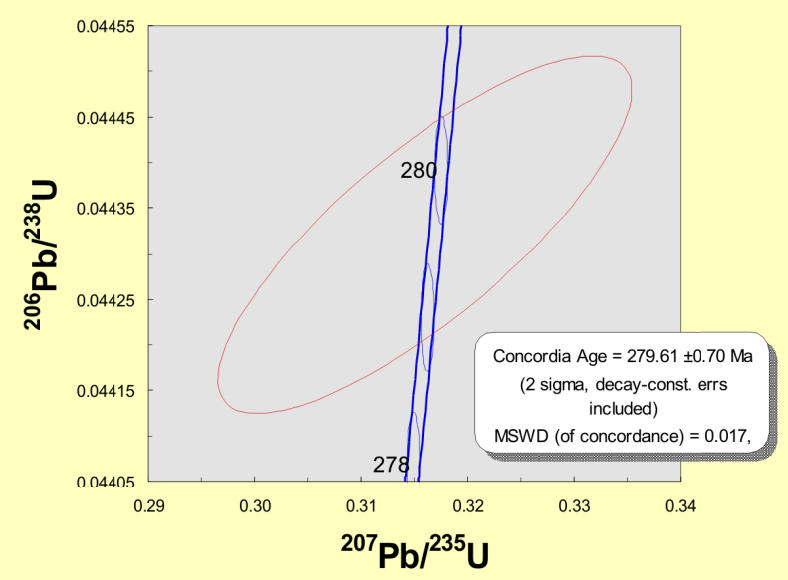

Figure 3-35-continued. Results from single zircon U-Pb ID-TIMS dating for sample AvQ 057

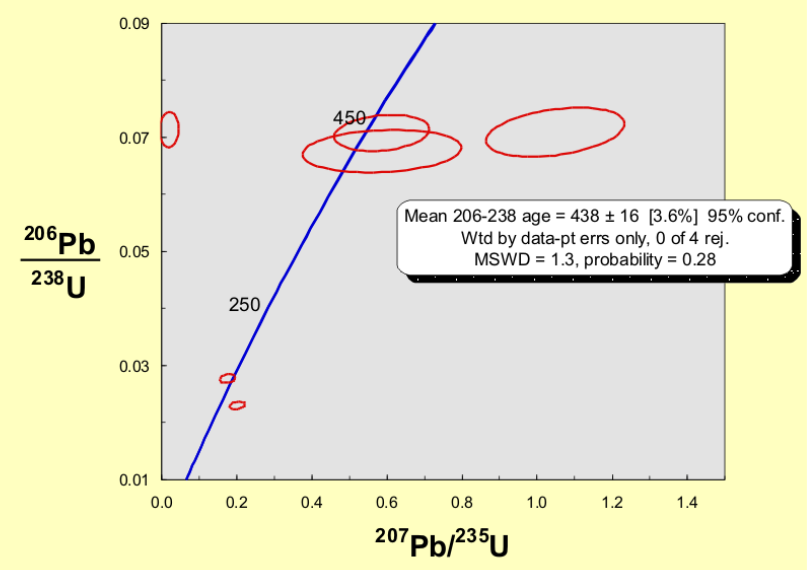

Figure 3-36. Results from single zircon U-Pb LA-ICPMS dating for sample AvQ 057

\section{AvQ 058 - Ankaramite, Izgrev}

The sample is taken from a small quarry exploiting volcanic rocks in Izgrev. All four ID-TIMS dated zircons exhibit an inherited age component (Figure 3-37a). Two grains are concordant at ca. 300 Ma (Figure 3-37 b), but they do not overlap each other. Together with a discordant older grain they form a discordia line with lower intercept at 295.6 $\pm 3.7 \mathrm{Ma}$ and upper intercept at $1948 \pm 37 \mathrm{Ma}$ and a MSWD of 0.6 (Figure 3-37c). One zircon is concordant at $445.5 \pm 1.6 \mathrm{Ma}$ (Figure $3-37 \mathrm{~d}$ ) but with a large ${ }^{207} \mathrm{~Pb} /{ }^{235} \mathrm{U}$ errorIt is possible that this zircon experienced some $\mathrm{Pb}$ loss and its crystallization age could be the $462.2 \pm 1.2 \mathrm{Ma}$ age observed in sample AvQ 057 (mafic intrusive from a nearby locality). In fact, this zircon lies on the discordia line formed by the Ordovician zircons from AvQ 057 which also show evidence of Pb loss. Five grains dated by LA-ICPMS have Late Cretaceous ages with limited overlap (Figure 3-38). Their weighted average ${ }^{206} \mathrm{~Pb} /{ }^{238} \mathrm{U}$ age of 75.7 \pm 7.0 at the $95 \%$ confidence limit has a high MSWD of 51 reflecting the data scatter. Additional analyses are needed to better constrain the crystallization age of the sample. 
a

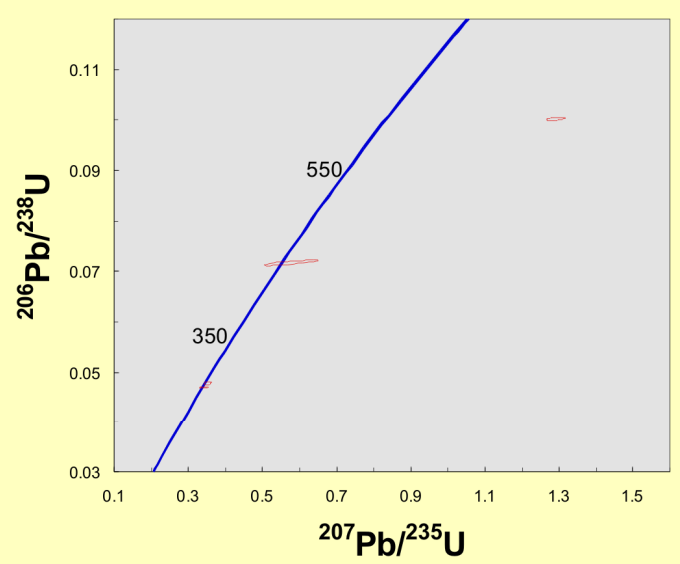

C

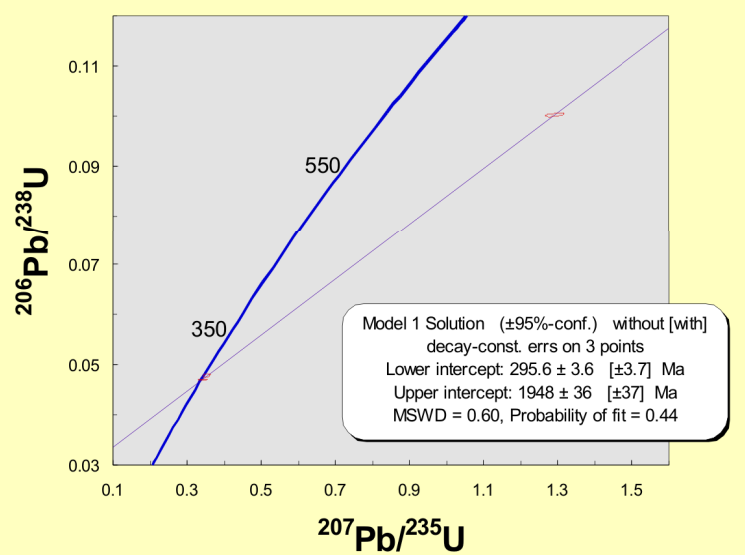

b

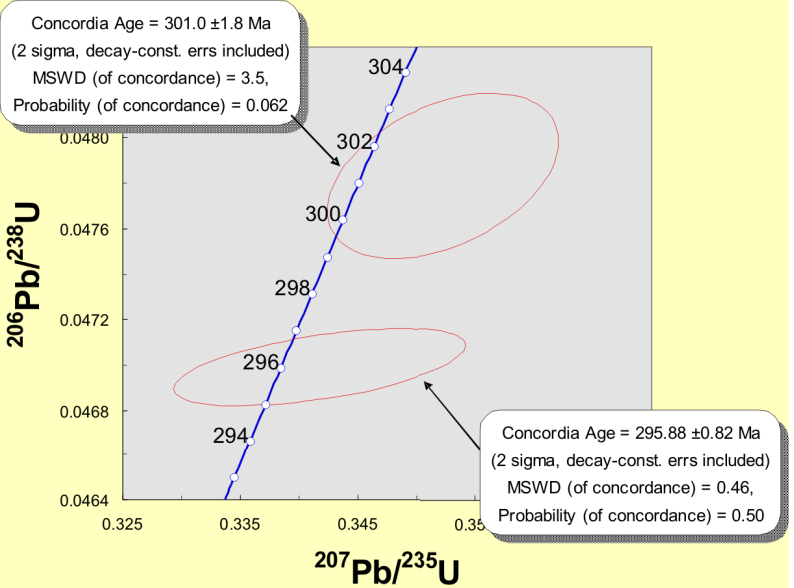

d

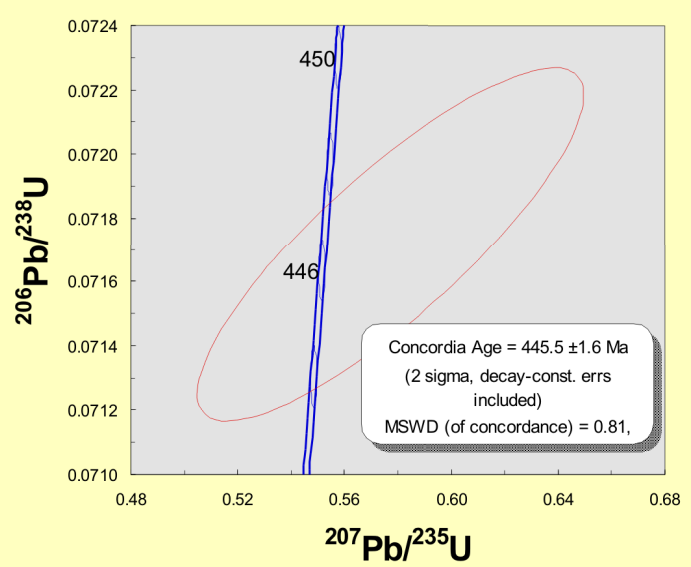

Figure 3-37. Results from single zircon U-Pb ID-TIMS dating for sample AvQ 058

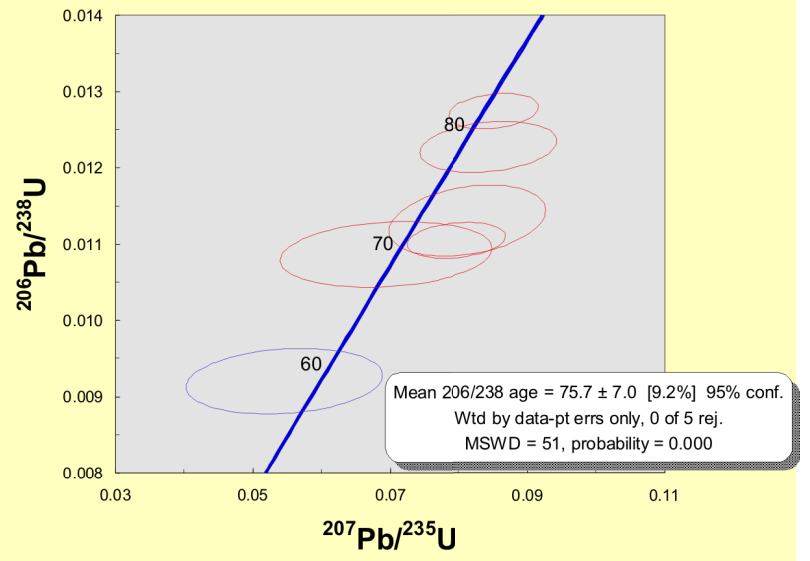

Figure 3-38. Results from single zircon U-Pb LA-ICPMS dating for sample AvQ 058 


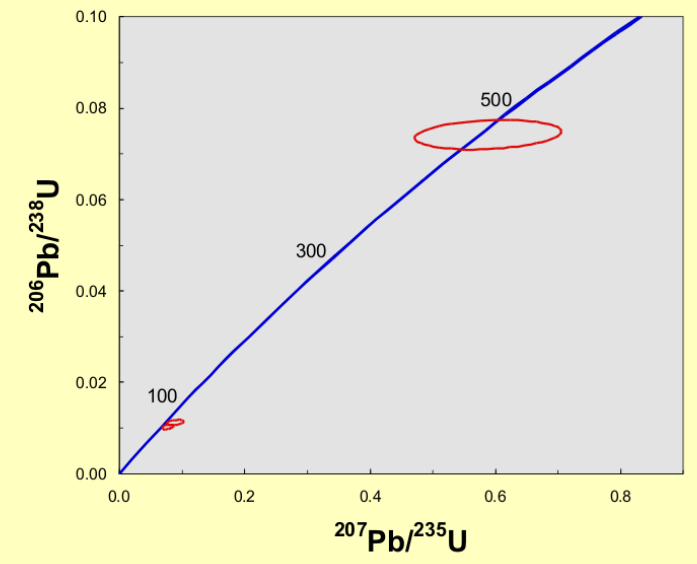

Three zircons were analyzed by LA-ICPMS $\mathrm{U}-\mathrm{Pb}$ method. One is concordant with large errors at ca. $450 \mathrm{Ma}$, and the remaining two have Late Cretaceous ${ }^{206} \mathrm{~Pb} /{ }^{238} \mathrm{U}$ ages (Figure 3-39). Additional analyses are needed to constrain the crystallization age of the sample.

\section{SG 040 - Diorite, Zidarovo pluton}

Nine zircons dated by LA-ICPMS suggestt a Late Cretaceous crystallization age of the sample (Figure 3-40a,b). One grain gives indication for an older component, while three grains are largely discordant (Figure 3-40a). The remaining four zircons form a somewhat coherent group at or near the concordia with a weighted average ${ }^{206} \mathrm{~Pb} /{ }^{238} \mathrm{U}$ age of $78.0 \pm 2.8 \mathrm{Ma}$ at the $95 \%$ confidence level and with a MSWD of 1.3 . The use of the zircon age extraction algorithm also yields a similar Late Cretaceous age with a smaller error (Figure 3-40b).

a

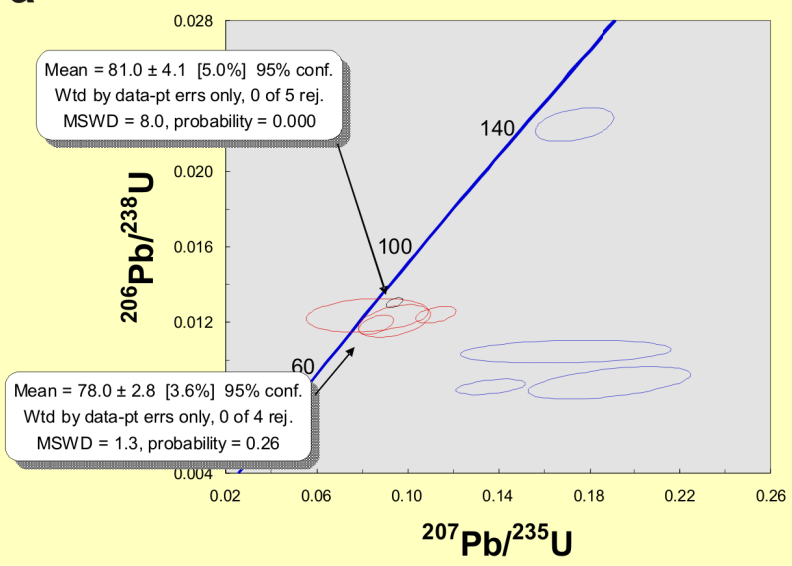

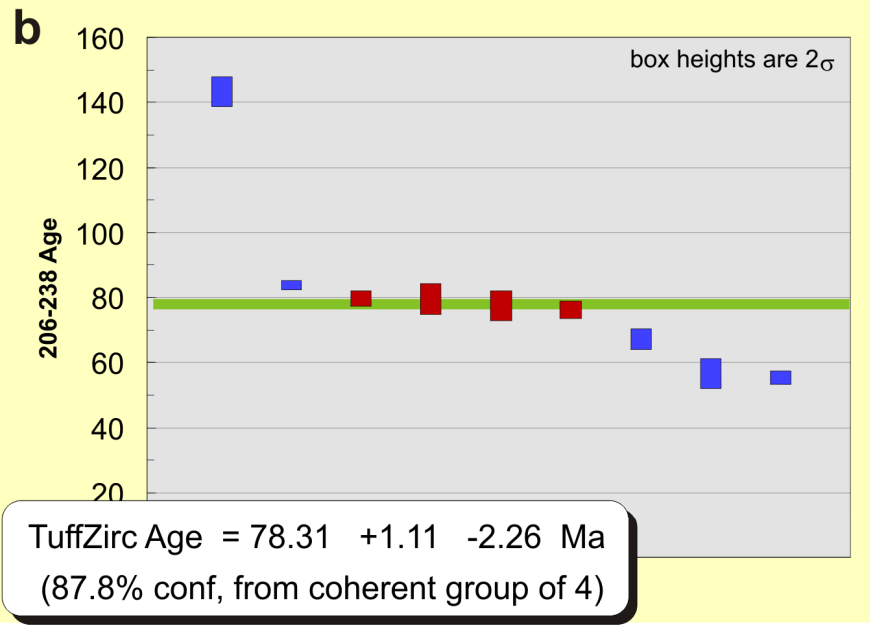

Figure 3-40. Results from single zircon U-Pb LA-ICPMS dating for sample SG 040

\section{SG 041 - fine-grained syenite, Vurli Brjag pluton}

LA-ICPMS dating on nine zircons shows disturbed U-Pb systematics (Figure 3-41a). The relative probability is highest for the group at $85 \mathrm{Ma}$ and this is also the age given by the zircon extraction age algorithm of ISOPLOT (Figure 3-41b, c). One grain with smaller errors is concordant at $80.97 \pm 0.70 \mathrm{Ma}$ and based on this age, it can be speculated that this syenite represents an earlier phase of the Vurli Brjag pluton (earlier compared to the SG 044 monzonite). However, the number of dated grains and their U-Pb systematics do not permit calculation of confident crystallization age of the sample. 
a

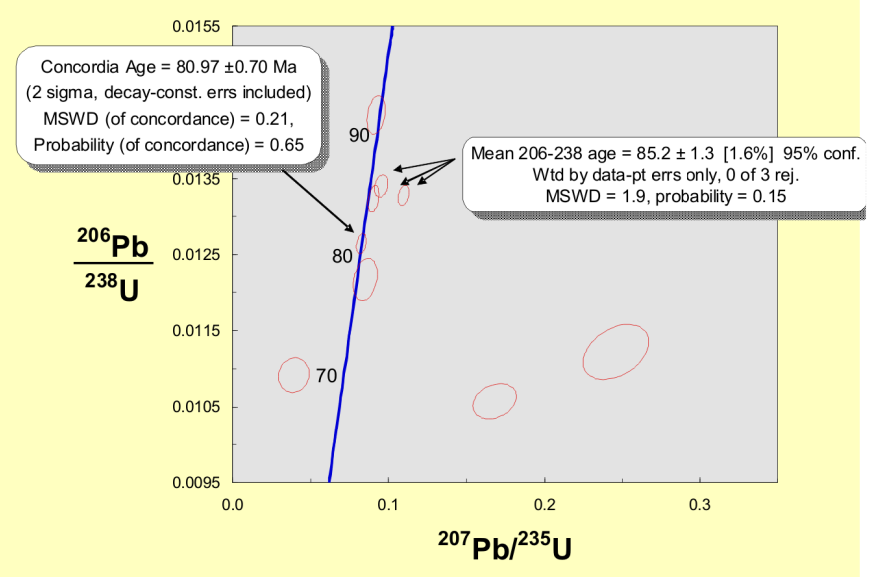

b

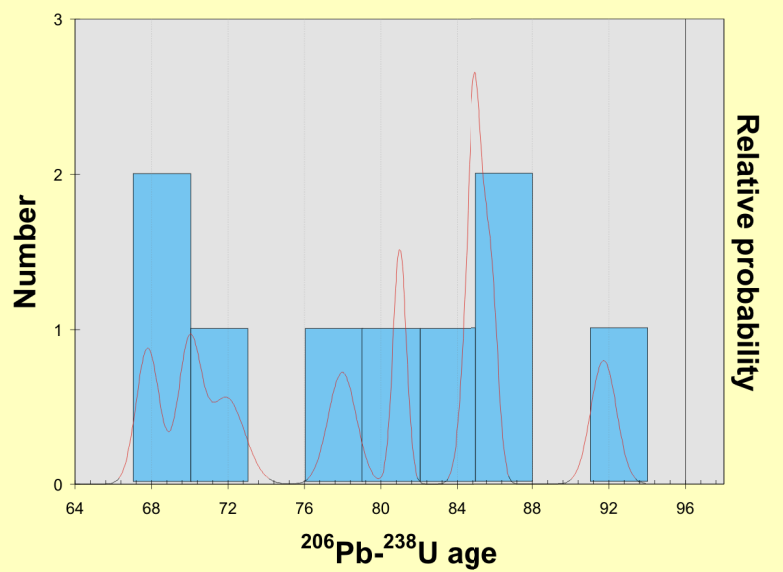

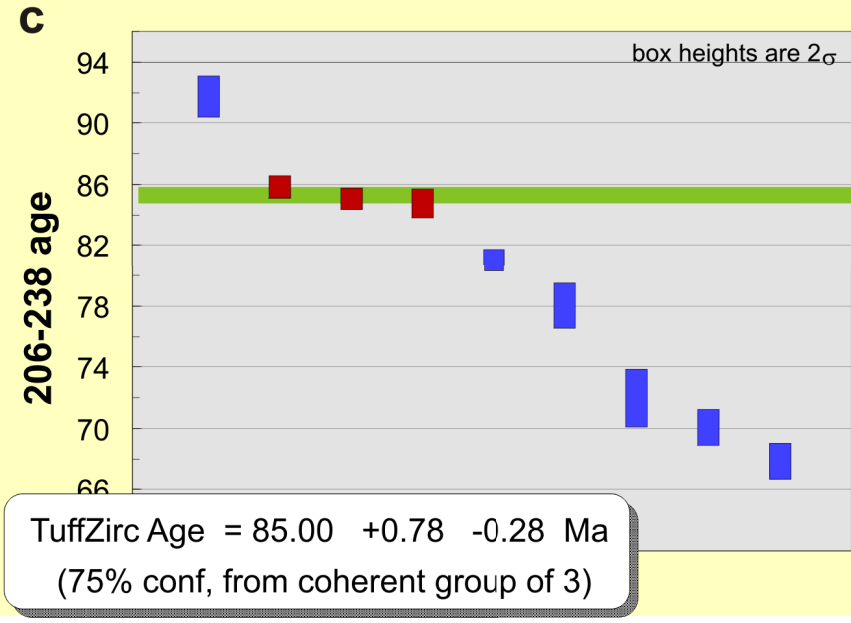

Figure 3-41. Results from single zircon $\mathrm{U}-\mathrm{Pb} \mathrm{LA}-$ ICPMS dating for sample SG 041

\section{SG 044 - Monzonite, Vurli Brjag pluton}

The sample is collected from a large quarry near the village of Gorno Ezerovo, close to the town of Burgas. The monzonite is intruded in a sequence of basalt and andesite lava flows and pyroclastic products with geochemically similar composition. Seven zircons air abraded for 3 hours were dated by ID-TIMS. They all have Late Cretaceous ages and lie at or next to the concordia band (Figure 3-42a). One grain apparently has a slightly older component and has a ${ }^{206} \mathrm{~Pb} /{ }^{238} \mathrm{U}$ age of $\sim 80.8 \mathrm{Ma}$. All remaining six zircons have ${ }^{206} \mathrm{~Pb} /{ }^{238} \mathrm{U}$ ages from 79.15 to $79.89 \mathrm{Ma}$ with a weighted average of $79.43 \pm 0.30 \mathrm{Ma}$. Four analyses form a discordia line with lower intercept of $78.98 \pm 0.31 \mathrm{Ma}$ and a MSWD of 1.5. Considering the large uncertainty of the upper

a

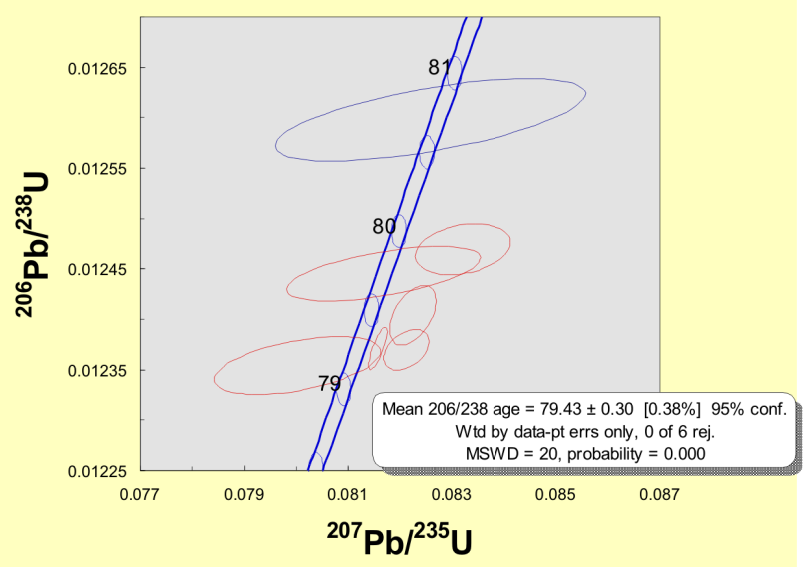

b

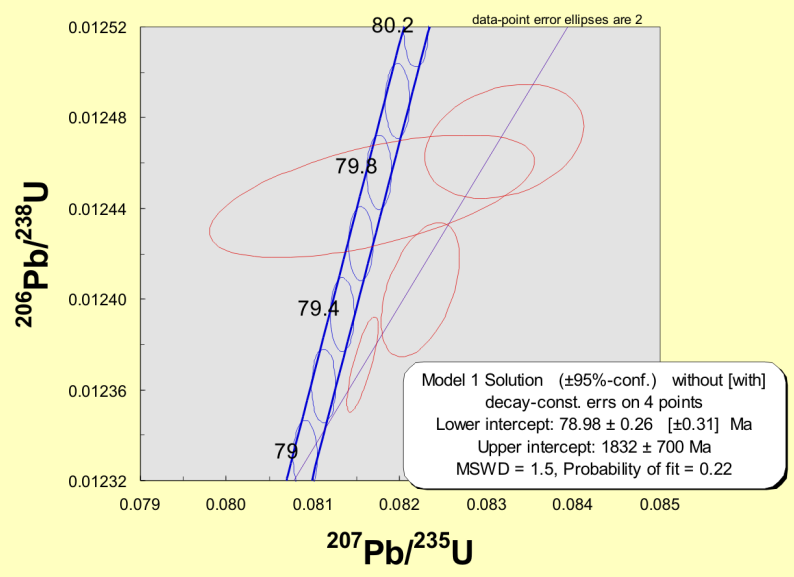

Figure 3-42. Results from single zircon U-Pb ID-TIMS dating for sample SG 044 
intercept and the evidence from CL and BSE imaging for homogeneous grains, we consider the weighted average ${ }^{206} \mathrm{~Pb} /{ }^{238} \mathrm{U}$ age of $79.43 \pm 0.30 \mathrm{Ma}$ a better estimate for the crystallization age of the rock than the lower intercept age. The relatively large scatter and small degree of discordance of the U-Pb ages could be due to limited amount of $\mathrm{Pb}$ loss.

Ten additional grains were analyzed by LA-ICPMS (Figure 3-43a). Seven grains overlap within their errors and give a concordia age of $79.42 \pm 0.96 \mathrm{Ma}$ at the $95 \%$ confidence limit (Figure 3-43b), which is in agreement with the ID-TIMS age of the rock.

a

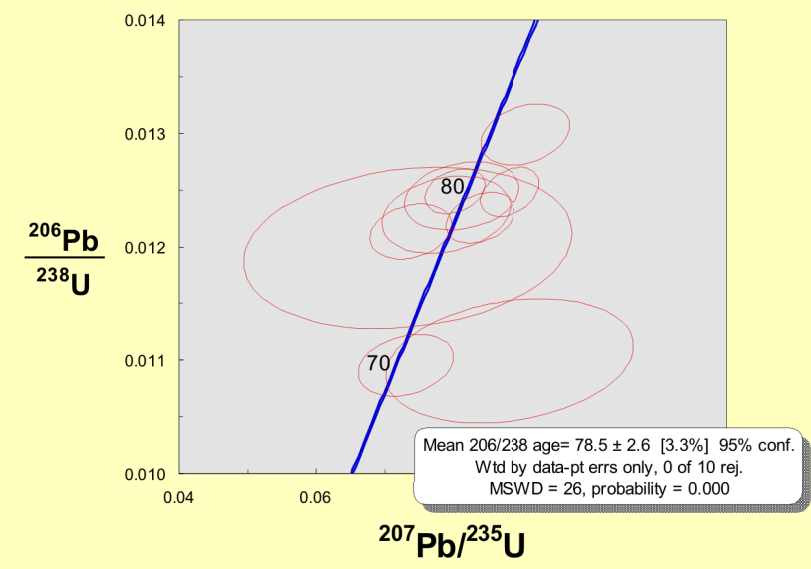

b

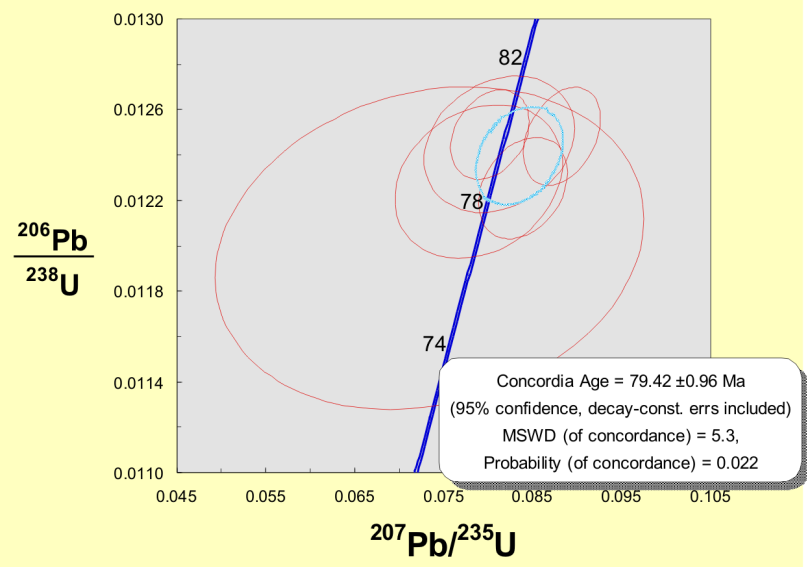

Figure 3-43. Results from single zircon U-Pb LA-ICPMS dating for sample SG 044

\section{SG 044b - Latite, Vurli Brjag}

The sample is from the same quarry as the SG 044 monzonite, from the volcanic sequence into which the monzonite was intruded. Four unabraded zircons were dated by ID-TIMS (Figure 3-44a). Two grains have Late Cretaceous ages: one discordant at $\sim 87 \mathrm{Ma}$, and one concordant with a larger error at $79.46 \pm 0.60 \mathrm{Ma}$ (Figure 3-44b). From the two older grains, one is broadly concordant at ca. $440 \mathrm{Ma}$ with a large ${ }^{207} \mathrm{~Pb} /{ }^{235} \mathrm{U}$ error, and one grain is concordant at 1039.3 $\pm 4.2 \mathrm{Ma}$ (Figure 3-44c). If the concordant grain at $1039 \mathrm{Ma}$ is excluded, the remaining three zircons form three different discordia chords with a Late Cretaceous lower intercept (Figure 3-44d, e, f). The constructed discordia line is not anchored on Figure 3-44d, anchored at the $443.53 \mathrm{Ma}{ }^{206} \mathrm{~Pb} /{ }^{238} \mathrm{U}$ age of the zircon (Figure 3-44e), or anchored at $462 \mathrm{Ma}$ (Figure 3-44f, $462 \mathrm{Ma}$ is the Ordovician age well documented in sample AvQ 057). The latter may be the most reliable age estimate, because it has the best MSDW from the three regressions. Regardless of whether we assume the concordant Late Cretaceous age (based on 1 grain), or either of the lower intercepts (based on 3-point regressions), we conclude that the SG 044b latite crystallization was broadly coeval with but still older than the intrusion of SG 044 monzonite. Additional analyses are needed to better constrain the age of the rock. 
a

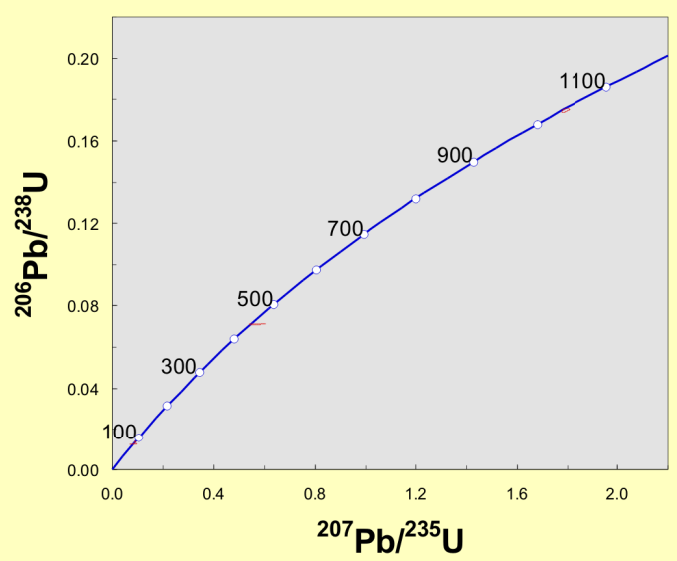

C

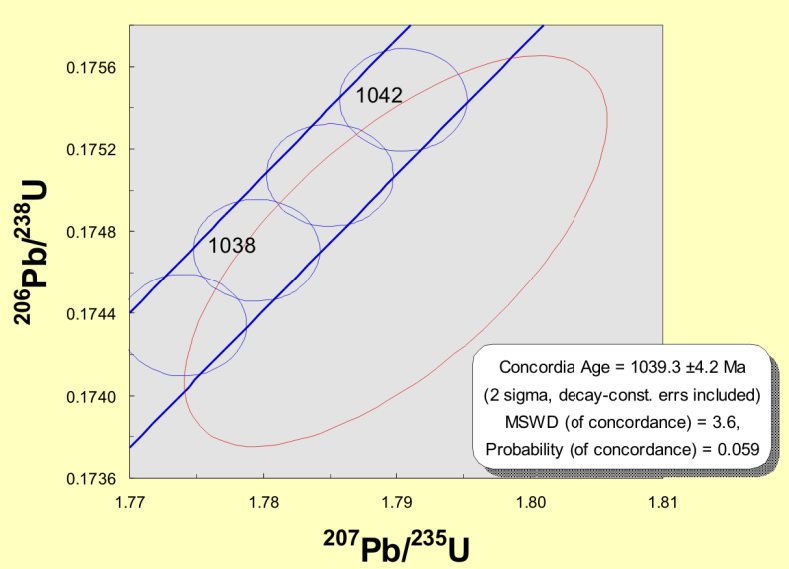

e

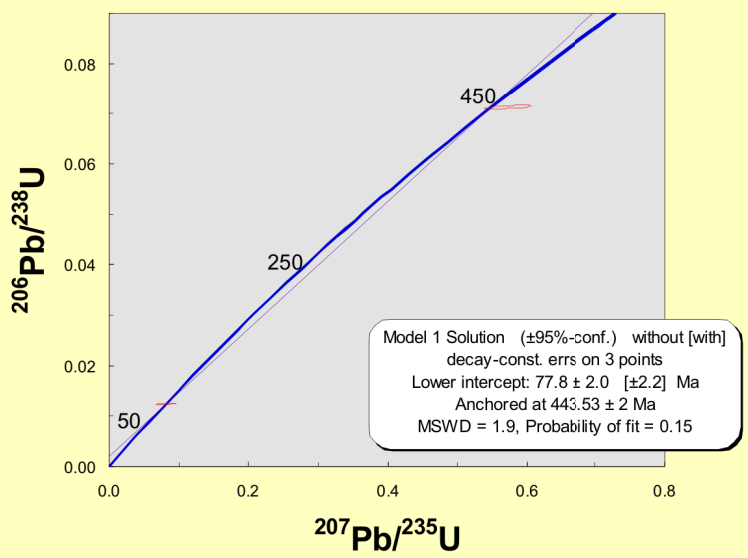

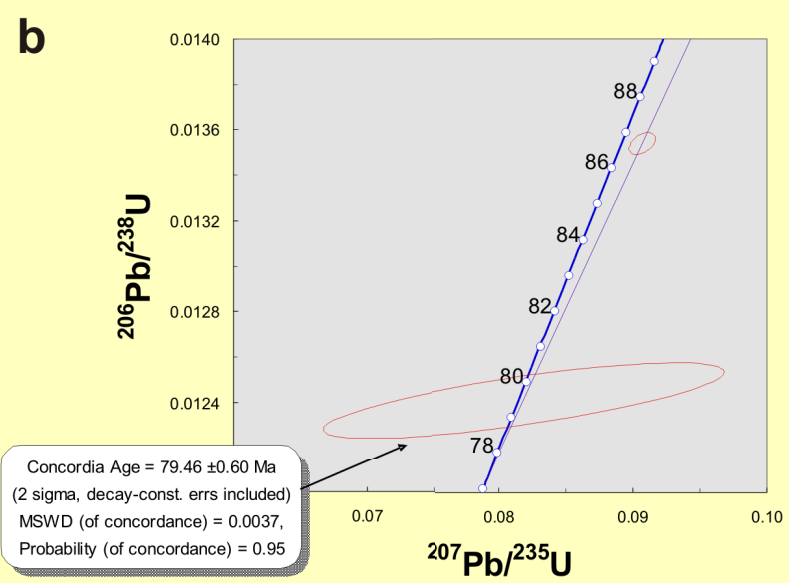

d

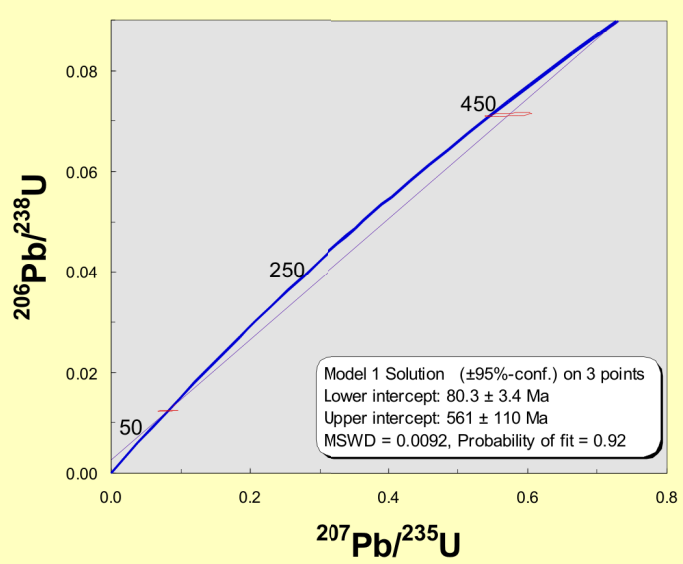

f

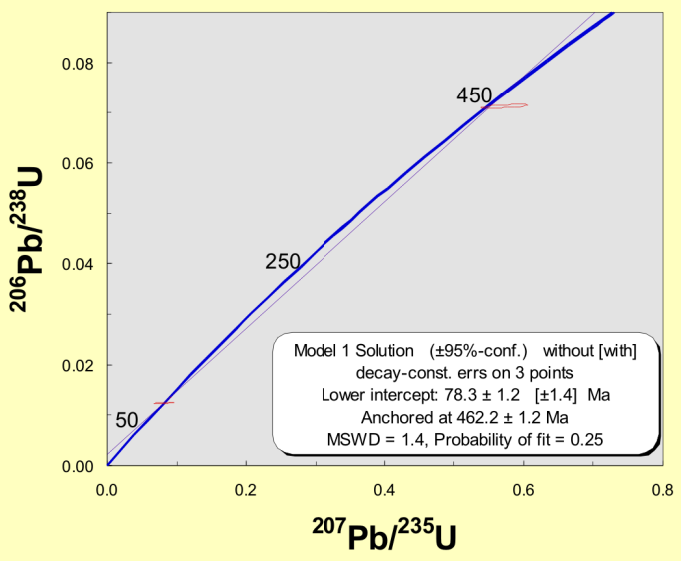

Figure 3-44. Results from single zircon U-Pb ID-TIMS dating for sample SG 044b 
SG 063 - Latite dike, near Izgrev

This dike cuts Late Cretaceous sediments from the Mitchurin group near the town of Tsarevo. Five air abraded for 6h zircons analyzed by ID-TIMS all show discordant ages (Figure 3-45a) ranging from 170 to $470 \mathrm{Ma}\left({ }^{206} \mathrm{~Pb} /{ }^{238} \mathrm{U}\right.$ ages). Currently, the best estimate for the crystallization age is the lower intercept age a three-point discordia line with a MSWD value of 0.56 that crosses the concordia at $104 \pm 28$ and $450 \pm 26 \mathrm{Ma}$ (Figure 3-45b). The Ordovician upper intercept age is relatively well defined and coincides within errors with the $\sim 460 \mathrm{Ma}$ inherited Ordovician ages observed in most studied rocks from the Yambol-Burgas region. The lower intercept however, with its large errors gives a broad range of ages from 76 to $132 \mathrm{Ma}$. Given the fact that the dike is intruded into Late Cretaceous sediments, its crystallization age has to be near the lower limit of this range. Additional analyses are needed to better constrain the age of the rock.

LA-ICPMS data for 14 zircon grains and one sphene are scattered along the concordia line with various degree of discordance and large errors (Figure 3-46a). Of them, two zircons and the sphene grain have Late Cretaceous ${ }^{206} \mathrm{~Pb} /{ }^{238} \mathrm{U}$ ages with a mean value of $73 \pm 19 \mathrm{Ma}$ with a high MSWD of 16 . The relative age probability plot of all grains graphically shows the large age spread and limited overlap (Figure 3-46b).

a

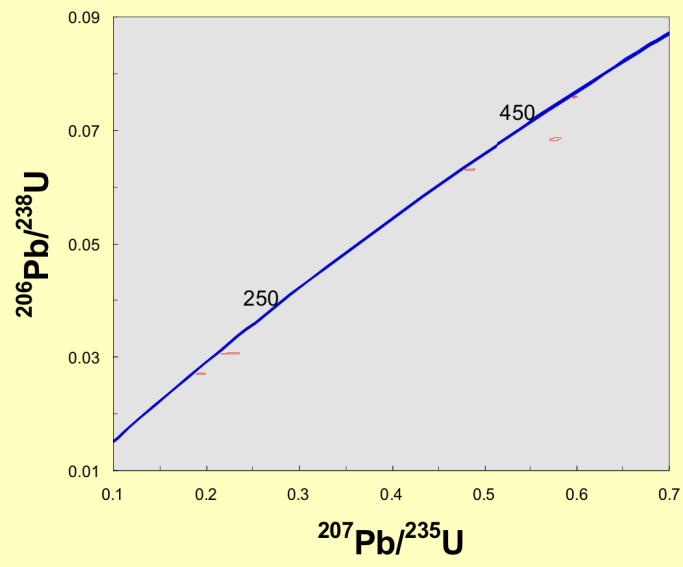

b

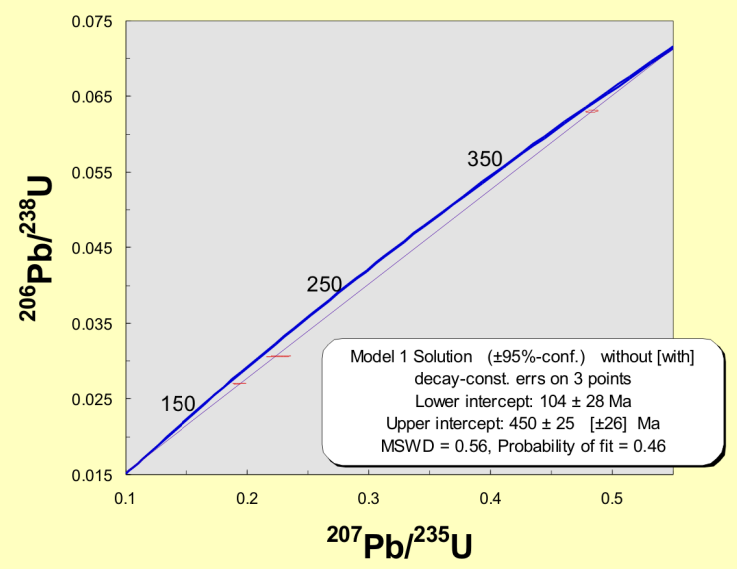

Figure 3-45. Results from single zircon U-Pb ID-TIMS dating for sample SG 063

a

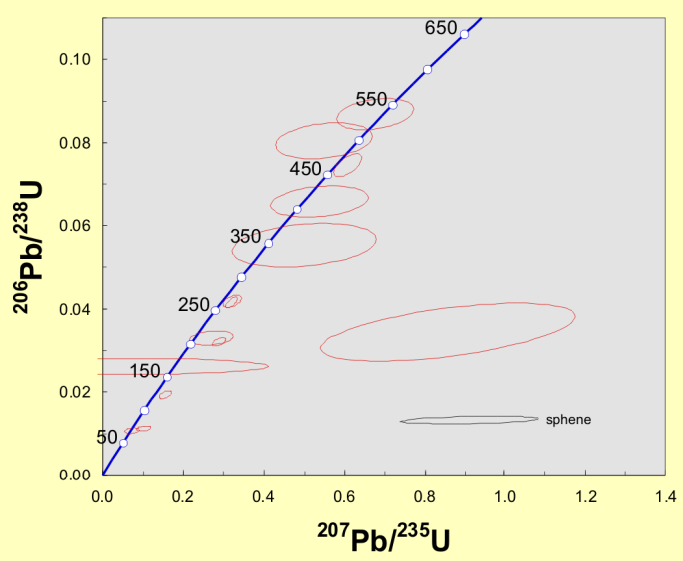

b

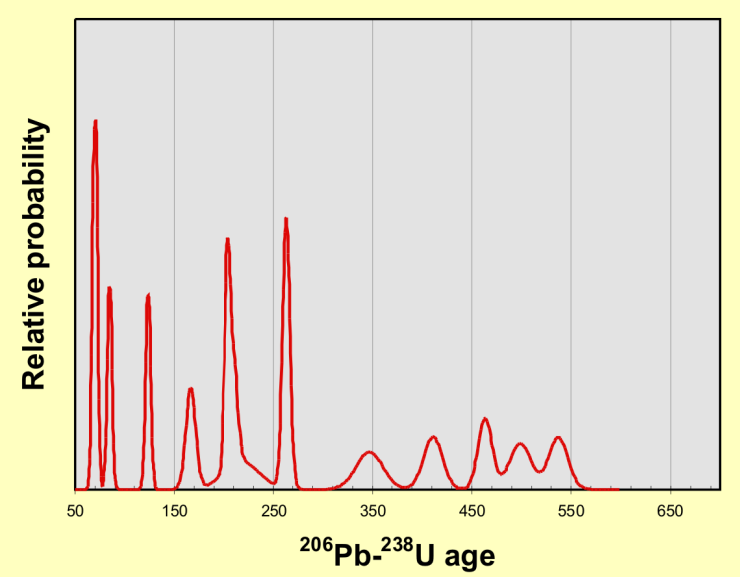

Figure 3-46. Results from single zircon U-Pb LA-ICPMS dating for sample SG 063 


\section{SG 066 - Qz-syenite dike, Vurli Brjag}

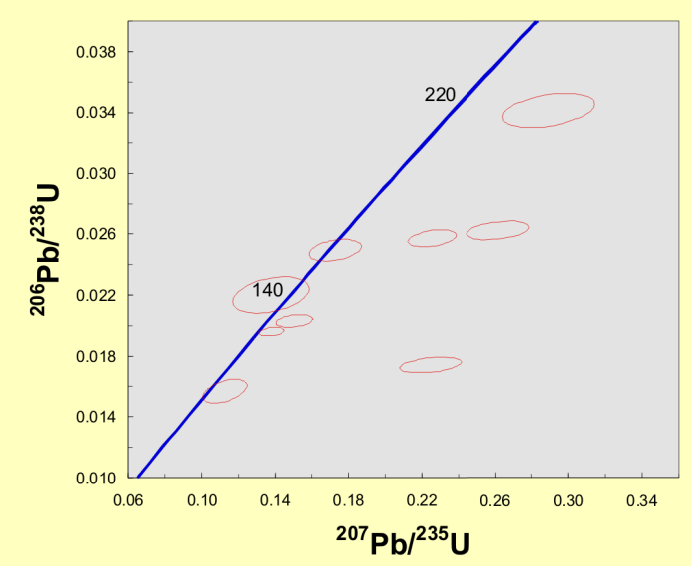

Nine variably discordant zircons dated by LA-ICPMS show scattered ${ }^{206} \mathrm{~Pb} /{ }^{238} \mathrm{U}$ ages (Figure 3-47). Additional analyses are needed to constrain the age of the rock.

Figure 3-47. Results from single zircon U-PB LA-ICPMS dating for sample SG 066

\section{SG 078 - Sub-alkaline granite, Rossen}

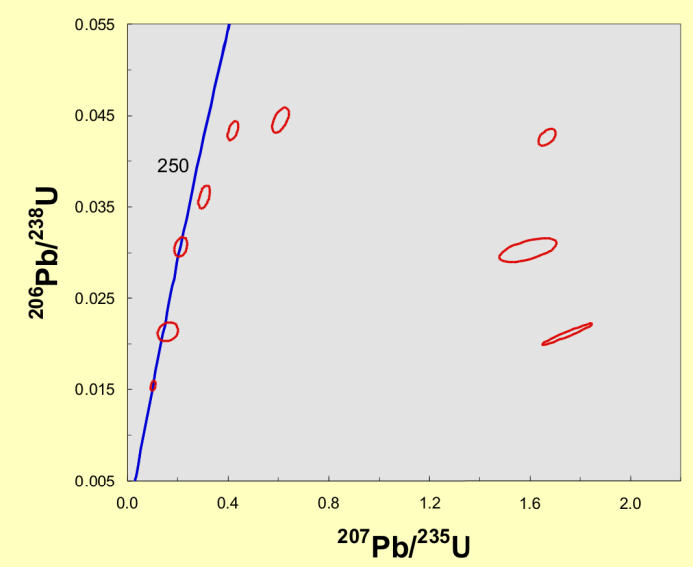

Nine zircons dated by LA-ICPMS show disturbed $\mathrm{U}-\mathrm{Pb}$ systematics and some of the analyses plot away from the concordia band (Figure 3-48). Three grains are concordant within their assigned errors at ca. 99, 136 and 194 Ma. Additional analyses are needed to constrain the age of the rock. This sample has unusually radiogenic whole-rock $\mathrm{Pb}$ and $\mathrm{Sr}$ isotopes resembling the values of the Variscan basement in the Strandzha region. However, the zircon data provide indications that its age is younger than Carboniferous/Permian.

Figure 3-48. Results from single zircon U-Pb LA-ICPMS dating for sample SG 078

\section{SG 079 - Diorite, Silistar}

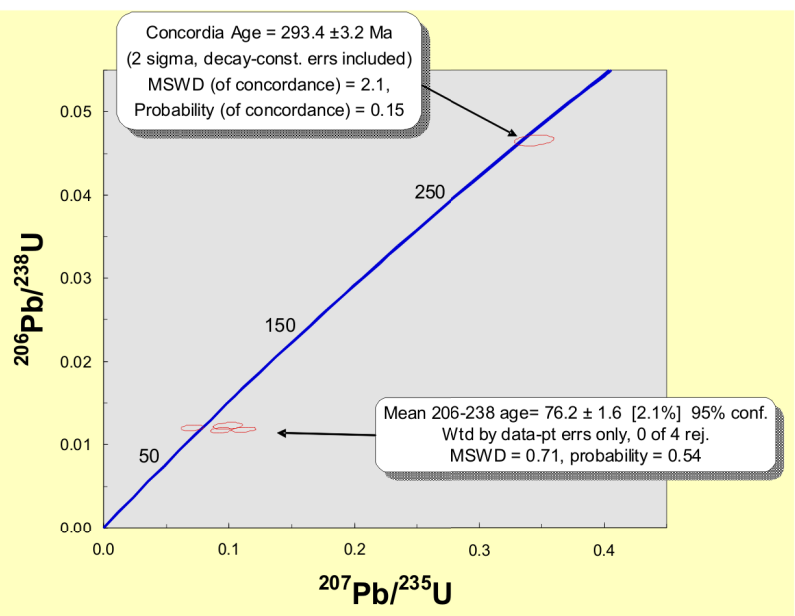

Five zircon were dated by LA-ICPMS. Four of them have similar ${ }^{206} \mathrm{~Pb} /{ }^{238} \mathrm{U}$ ages with a weighted average of 76.2 $\pm 1.6 \mathrm{Ma}$ and MSWD of 0.71 (Figure 3-49), which is considered to be the crystallization age of the rock. One older grain is concordant at $293.4 \pm 3.2 \mathrm{Ma}, 2$ sigma level.

Figure 3-49. Results from single zircon U-Pb LA-ICPMS dating for sample SG 079 


\section{SG 090 - Ankaramite, Krushevets}

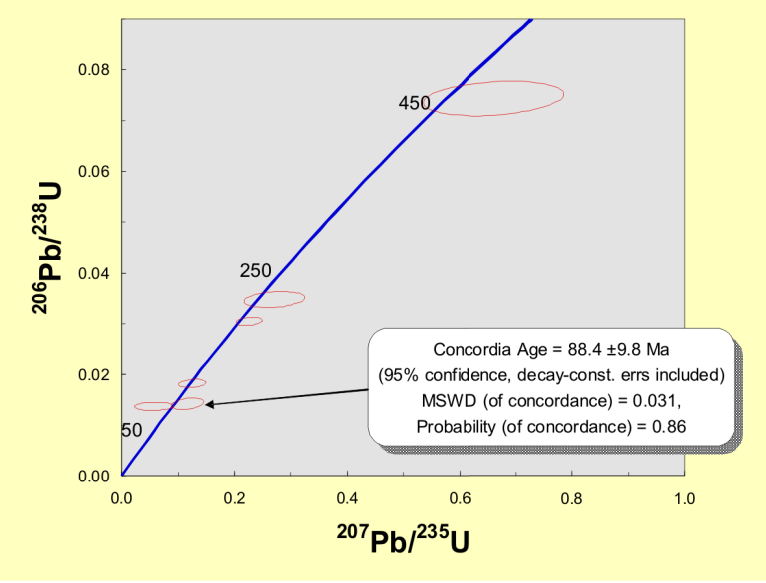

Six zircons analyzed by LA-ICPMS have ${ }^{206} \mathrm{~Pb} /{ }^{238} \mathrm{U}$ ages ranging from Late Cretaceous to Ordovician (Figure 3-50). The two youngest zircons have limited overlap and yield a poorly defined concordia age of $88.4 \pm 9.8 \mathrm{Ma}$ at the $95 \%$ confidence level. Additional analyses are needed to better constrain the age of the rock.

Figure 3-50. Results from single zircon U-Pb LA-ICPMS dating for sample SG 090

\section{SG 102d - Dacite, Tamarino Bakadzhik}

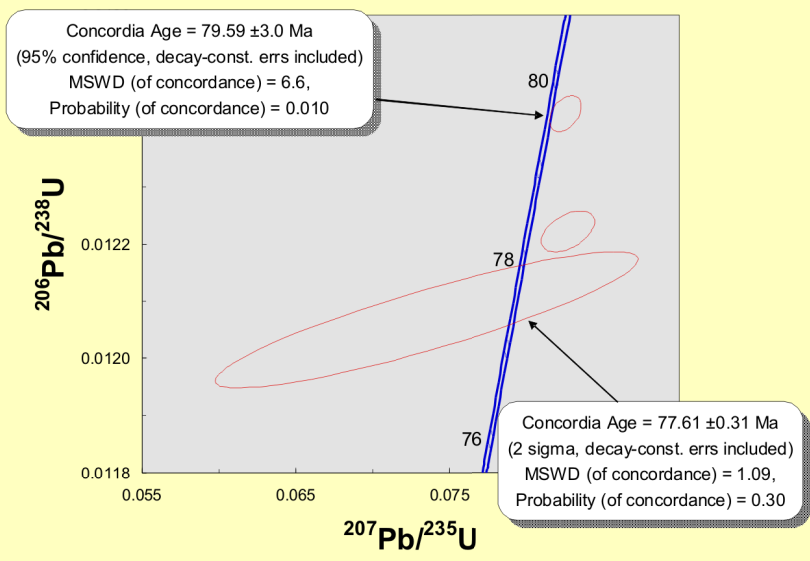

Figure 3-51. Results from single zircon U-PB ID-TIMS dating for sample SG $102 \mathrm{~d}$

The sample is from a weathered and altered dacite from the Tamarino Bakadzhik center. Three air abraded for 6 hours grains measured by IDTIMS all show evidence of $\mathrm{Pb}$ loss (Figure 3-51) Two zircons overlap with the concordia band, one with larger error gives a concordia age of 77.61 $\pm 0.31 \mathrm{Ma}$ at the 2 sigma level; the second zircon has smaller errors but overlaps only slightly with the concordia and yields an age of 79.59 \pm 3.0 Ma at the 95\% confidence levels. Published K_Ar ages for the Tamarino Bakadzhik are $\sim 80 \mathrm{Ma}$. The three studied zircons may also have crystallized at $\sim 80 \mathrm{Ma}$ but later experienced small amounts of $\mathrm{Pb}$ loss which shifted their position off the concordia. Additional analyses are needed to better constrain the age of the rock.

LA-ICPMS data for eight zircons show ${ }^{206} \mathrm{~Pb} /{ }^{238} \mathrm{U}$ ages ranging from 60 to $80 \mathrm{Ma}$ (Figure 3-52a). Three grains overlap at $\sim 80 \mathrm{Ma}$ and yield a weighted average ${ }^{206} \mathrm{~Pb} /{ }^{238} \mathrm{U}$ age of $80.1 \pm 5.6 \mathrm{Ma}$. If all younger grains are considered, a discordia line can be constructed 73.0 $\pm 6.6 \mathrm{Ma}$ and $1469 \pm 240 \mathrm{Ma}$ for the lower and upper intercept, respectively. The relative probability plot shows a Late Cretaceous peak, in addition to indications of a Permian-Triassic event (Figure 3-52c), whereas the Jurassic peak comes from a single, largely discordant zircon and is therefore less informative. 
a

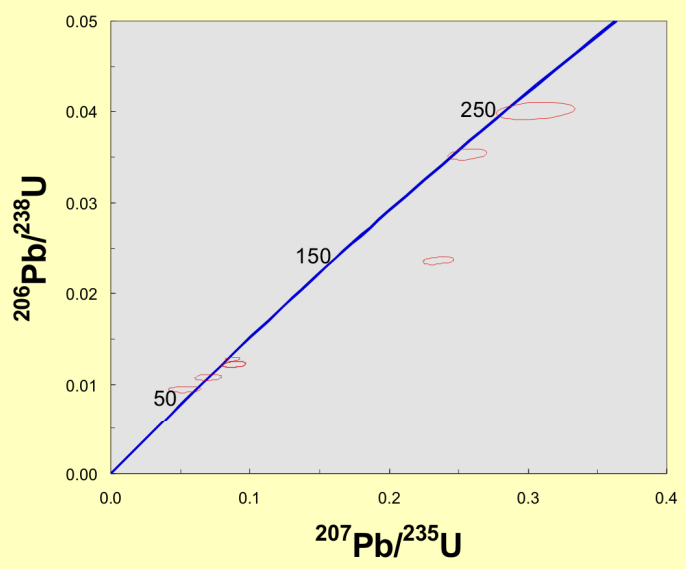

b

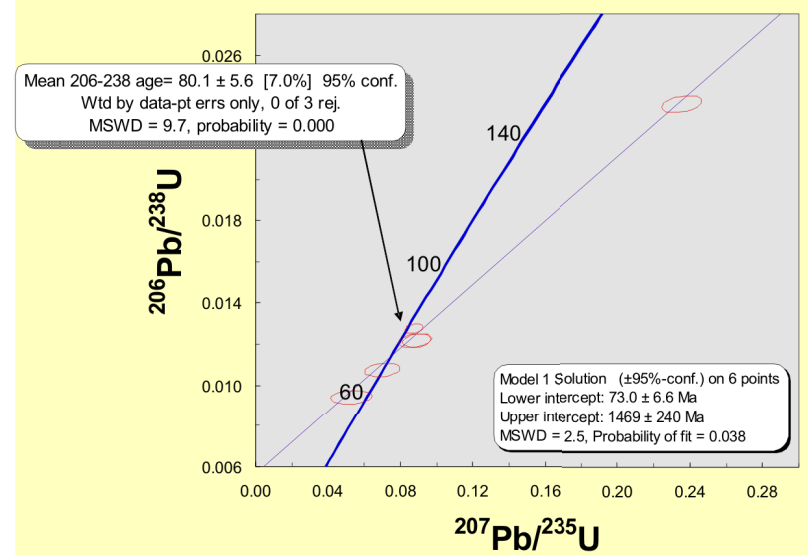

C

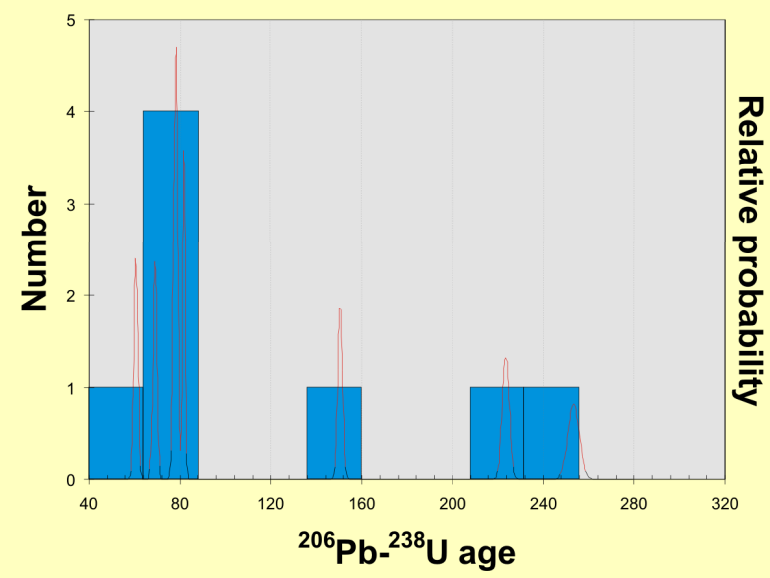

Figure 3-52. Results from single zircon U-Pb LA-ICPMS dating for sample SG 102d

SG 103 - Latite, Sv.Spaski Bakadzhik

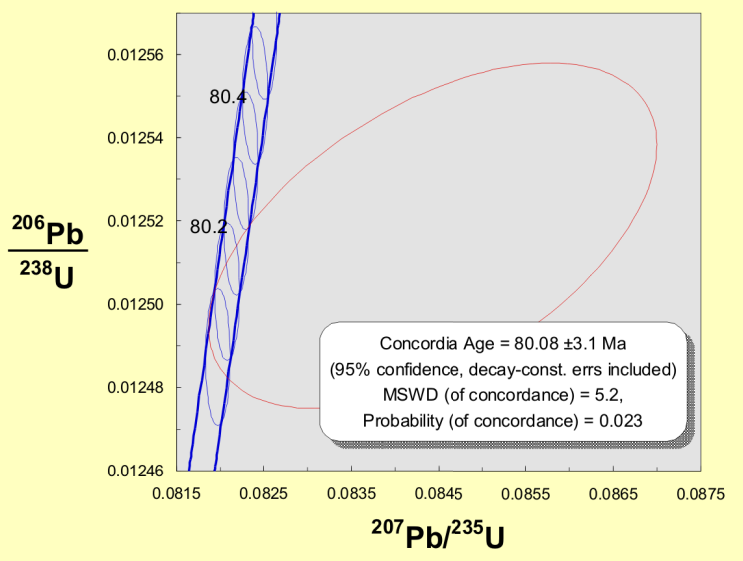

Figure 3-53. Results from single zircon U-Pb ID-TIMS dating for sample SG 103
The single grain analyzed by ID-TIMS has a concordia age of $80.08 \pm 3.1 \mathrm{Ma}, 95 \%$ confidence level (Figure 3-53), with a slight discordance.

Eight zircons dated by LA-ICPMS all show Late Cretaceous ages and plot at or near the concordia curve (Figure 3-54a). Their ${ }^{206} \mathrm{~Pb} /{ }^{238} \mathrm{U}$ ages range from 72.3 to $81.3 \mathrm{Ma}$ and produce a wide peak on the probability plot (Figure 3-54b). Five of the grains overlap within their error and yield a concordia age of $74.7 \pm 1.9 \mathrm{Ma}$ at the 95\% confidence level (Figure 3-54c). A slightly older age of $75.69 \mathrm{Ma}$ is given by the zircon age extraction algorithm (Figure 3-54d).

Given that the only ID-TIMS analyses has an older ${ }^{206} \mathrm{~Pb} /{ }^{238} \mathrm{U}$ age of $\sim 80 \mathrm{Ma}$, we consider the $76.8 \pm 2.9 \mathrm{Ma}$ weighted average ${ }^{206} \mathrm{~Pb} /{ }^{238} \mathrm{U}$ age of all analyzed grains (Figure 3-54a) as the best 
estimate for the crystallization age of the sample, regardless of the high MSWD value of 7. Additional analyses are needed to better constrain the age of the rock.

a

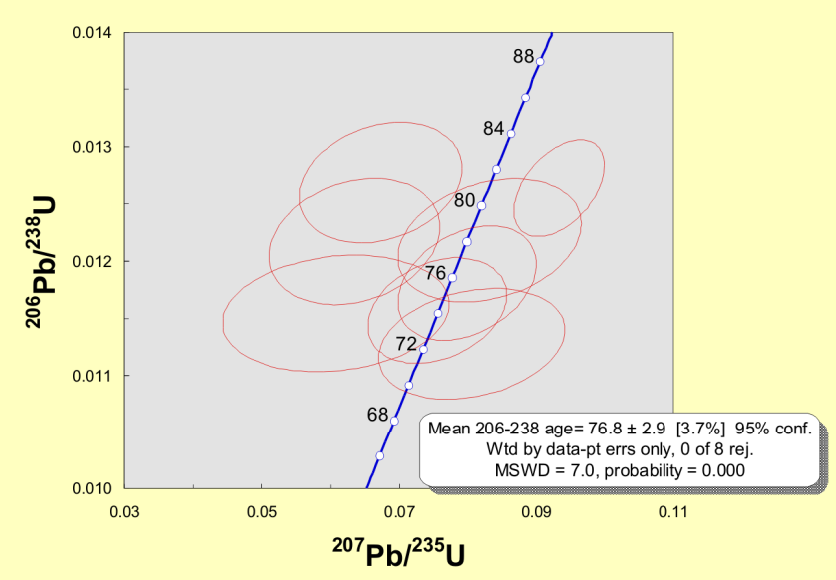

C

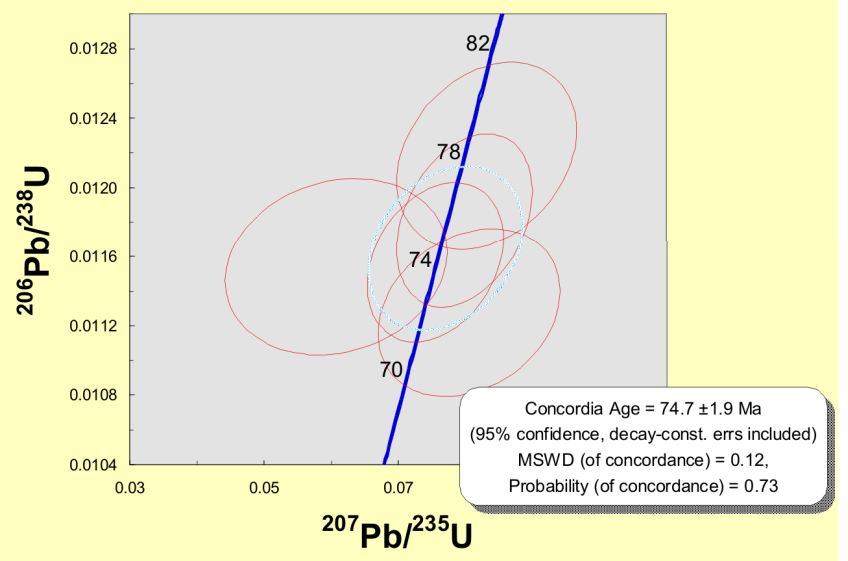

b
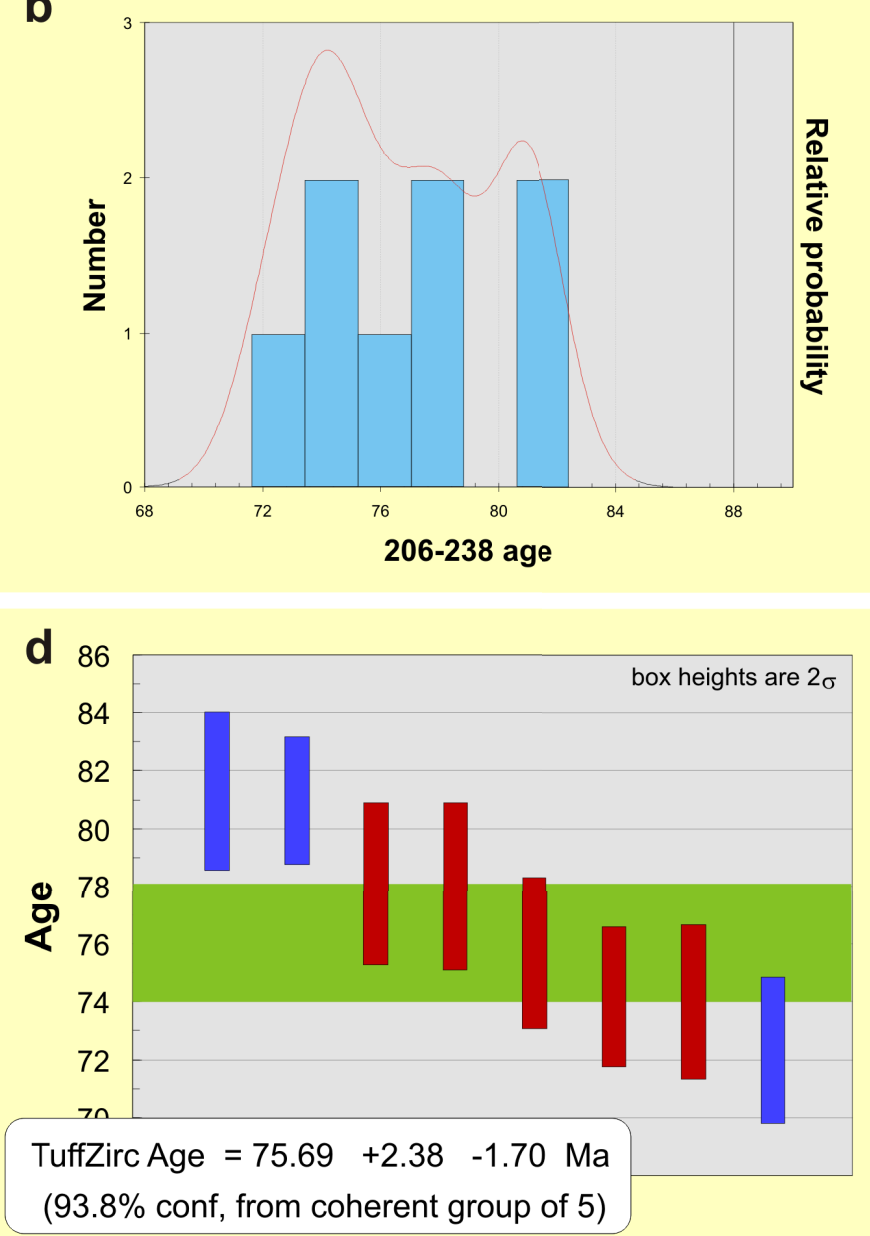

Figure 3-54. Results from single zircon U-Pb LA-ICPMS dating for sample SG 103

\subsection{NORTH BURGAS region}

\section{SG 085 - Alkaline trachyte, Balgarovo}

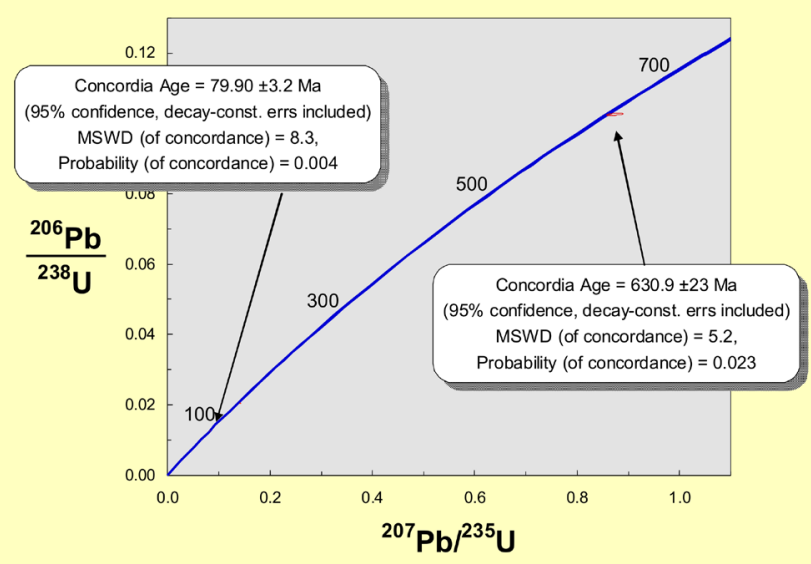

Figure 3-55. Results from single zircon U-Pb ID-TIMS dating for sample SG 085
Three grains analyzed by ID-TIMS yielded three different and slightly discordant ages (Figure 3-55). At the $95 \%$ confidence limit one zircon has a concordia age of $79.90 \pm 3.2 \mathrm{Ma}$ and the oldest grain yields a concordia age of $630.9 \pm 23 \mathrm{Ma}$ (Figure 3-55).

Both grains have older ${ }^{207} \mathrm{~Pb} /{ }^{235} \mathrm{U}$ ages and it is possible that they experienced $\mathrm{Pb}$ loss, or that they have an older inherited component. Three zircons and one apatite grain, analyzed by LA-ICPMS have largely discordant and older than Late Cretaceous ages. Additional analyses are needed to constrain the age of the rock. 


\section{SG 068 - Diorite porphyry}

The sample is collected at Assara peak in the Eastern Balkan Mountains, near the village of Zvezda. Thirteen zircon grains and four monazites were analyzed by ID-TIMS. The analyzed air abraded and chemically abraded zircons show a wide range of ${ }^{206} \mathrm{~Pb} /{ }^{238} \mathrm{U}$ ages from ca. 41 to $366 \mathrm{Ma}$ (Figure 3-56a). Four zircons are concordant within their relatively large errors at 41.55 $\pm 0.10 \mathrm{Ma}, 61.18 \pm 0.27 \mathrm{Ma}, 136.23 \pm 0.44$ Ma and 290.7 \pm 2.9 Ma respectively (Figure 3-57).

Two chemically abraded zircons are concordant with considerably smaller error ellipses at $298.98 \pm 0.50$ Ma, 303.49 \pm 0.45 Ma respectively and demonstrate the upper limits of precision and concordance achieved in this study (Figure 3-58, b). The zircons with the oldest ${ }^{206} \mathrm{~Pb} /{ }^{238} \mathrm{U}$ ages are slightly displaced from the concordia band and yield concordia ages of $349.94 \pm 9.6 \mathrm{Ma}$ and $366.20 \pm 12 \mathrm{Ma}$ within their $95 \%$ confidence interval (Figure 3-58c, d). Despite the large number of concordant grains, the analyses do not overlap and the age of the rock cannot be determined. There seem to be no systematic relation between the ${ }^{206} \mathrm{~Pb} /{ }^{238} \mathrm{U}$ age and the variable external morphology of the zircons.

None of the chemically abraded zircons shows the Eocene-Paleocene (42 and $61 \mathrm{Ma}$ ) ages. The younger 42 and 61 Ma zircons have comparatively larger errors, which hinders detail age interpretation. An attempt was made to calculate possible discordia lines with the remaining discordant zircons. The three scenarios that yield statistically reasonable MSWD ( Figure 3-56 b, c, d) indicate a possible Early Cretaceous event in addition to the well defined from the concordant zircons Carboniferous/Permian inheritance. In an unsuccessful attempt to determine the age of the rock, additional ten zircons (Figure 3-59) and two sphene grains were analyzed by

a

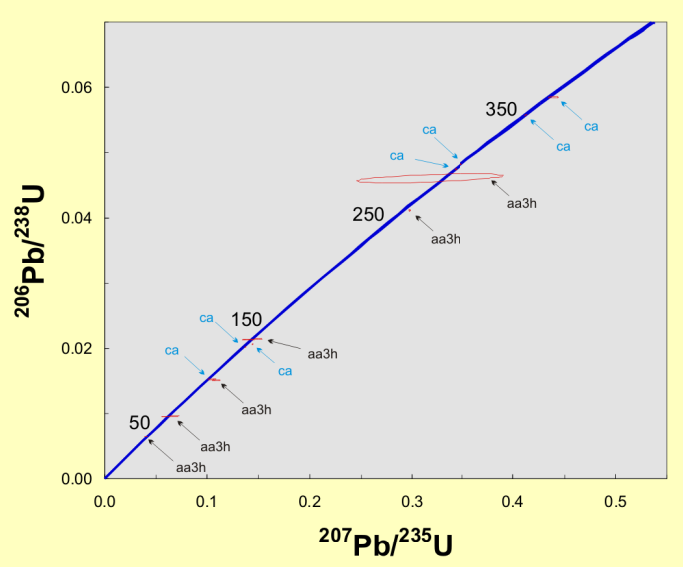

C

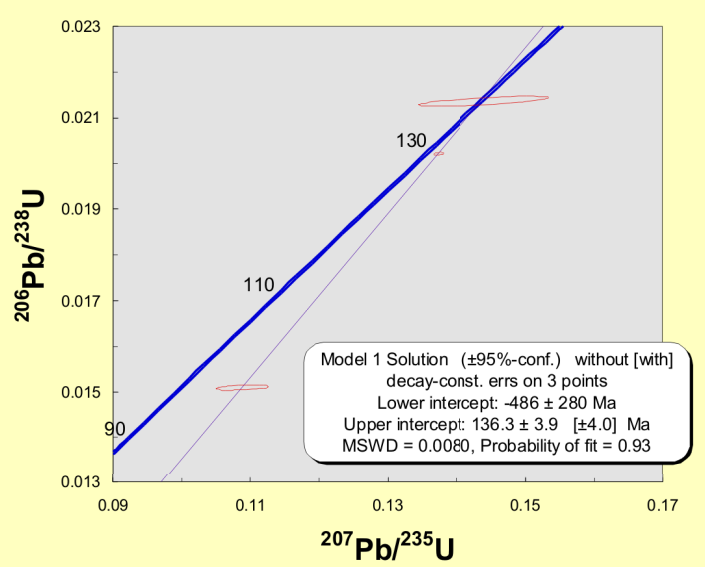

b

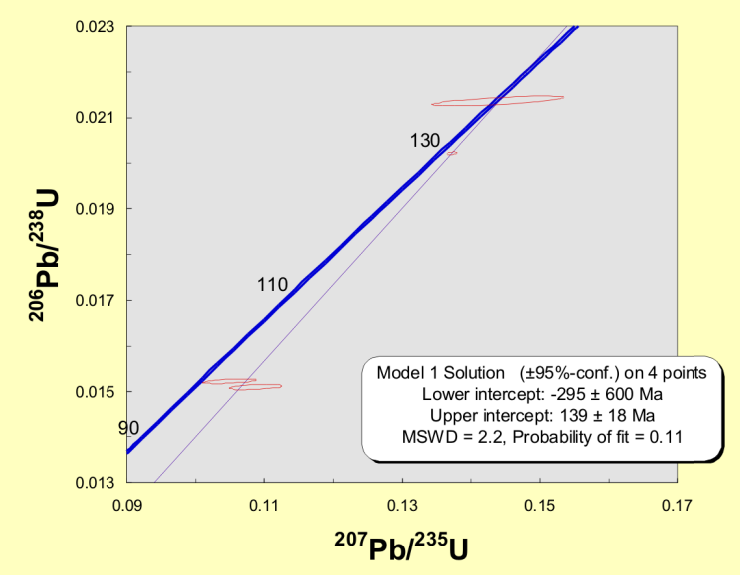

d

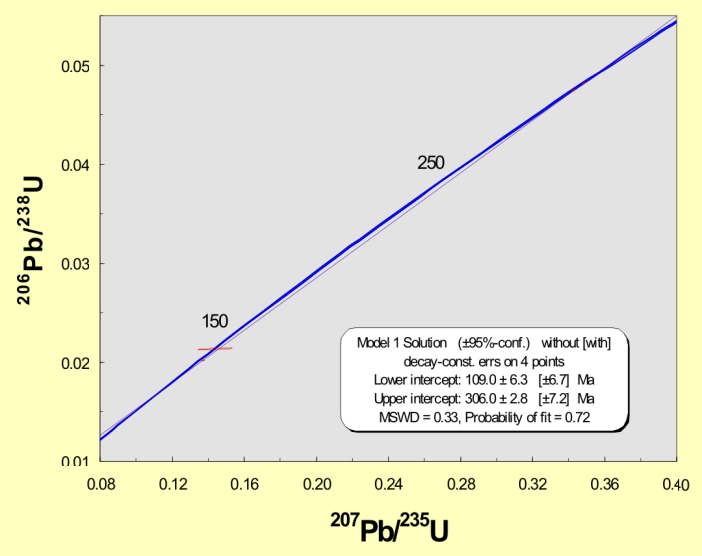

Figure 3-56. Results from single zircon U-Pb ID-TIMS dating for sample SG 068 
LA-ICPMS. Zircon data is scattered and several possible groups can be recognized based on their ${ }^{206} \mathrm{~Pb} /{ }^{238} \mathrm{U}$ age, including the clustering of three data points at ca. $80 \mathrm{Ma}$. The sphene grains are grossly discordant.

The combined ID-TIMS and LA-ICPMS age data for SG 068 zircons are presented on Figure 3-60.

The relative probability of the zircon measurements indicates peaks at ca. 61,96 and 131 Ma in addition to the Variscan peaks. The position and height of the peaks are controlled dominantly the more precise ID-TIMS data.

a

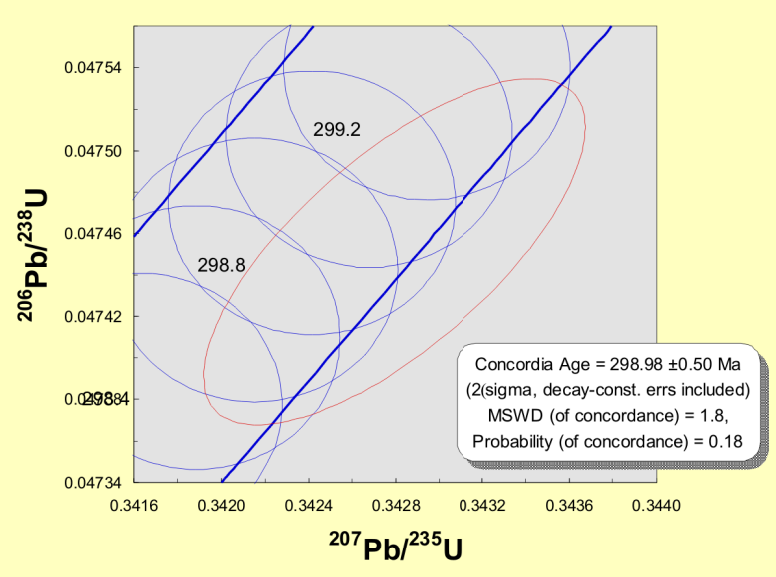

C

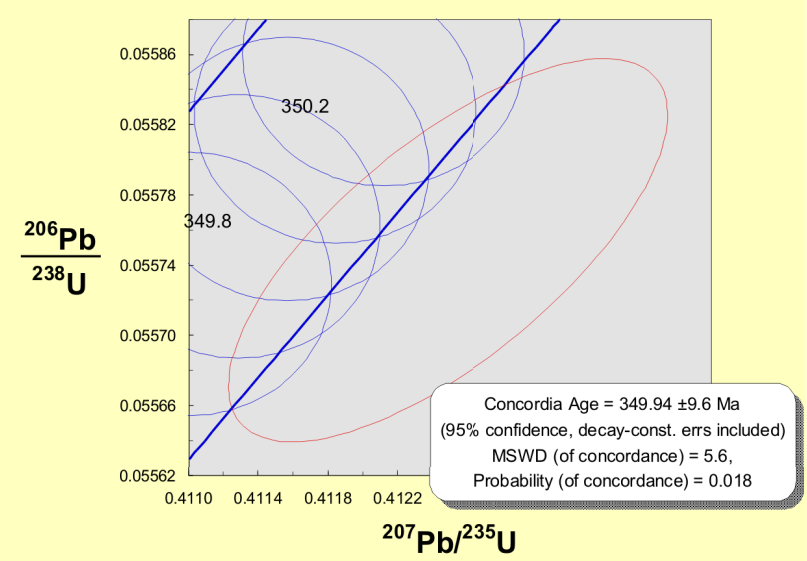

b

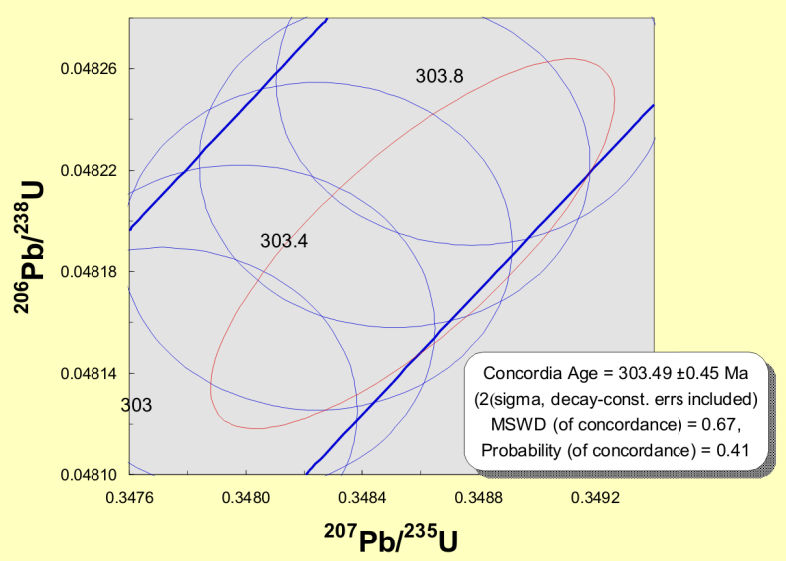

d

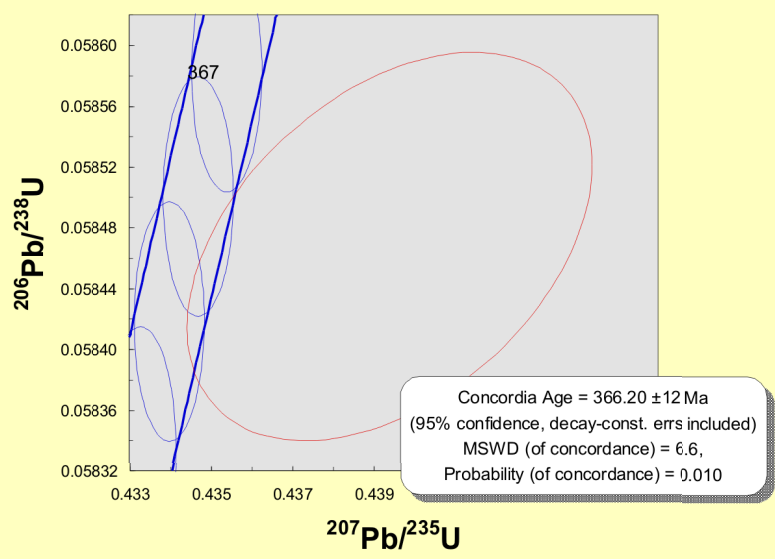

Figure 3-57. Results from single zircon U-Pb ID-TIMS dating for sample SG 068
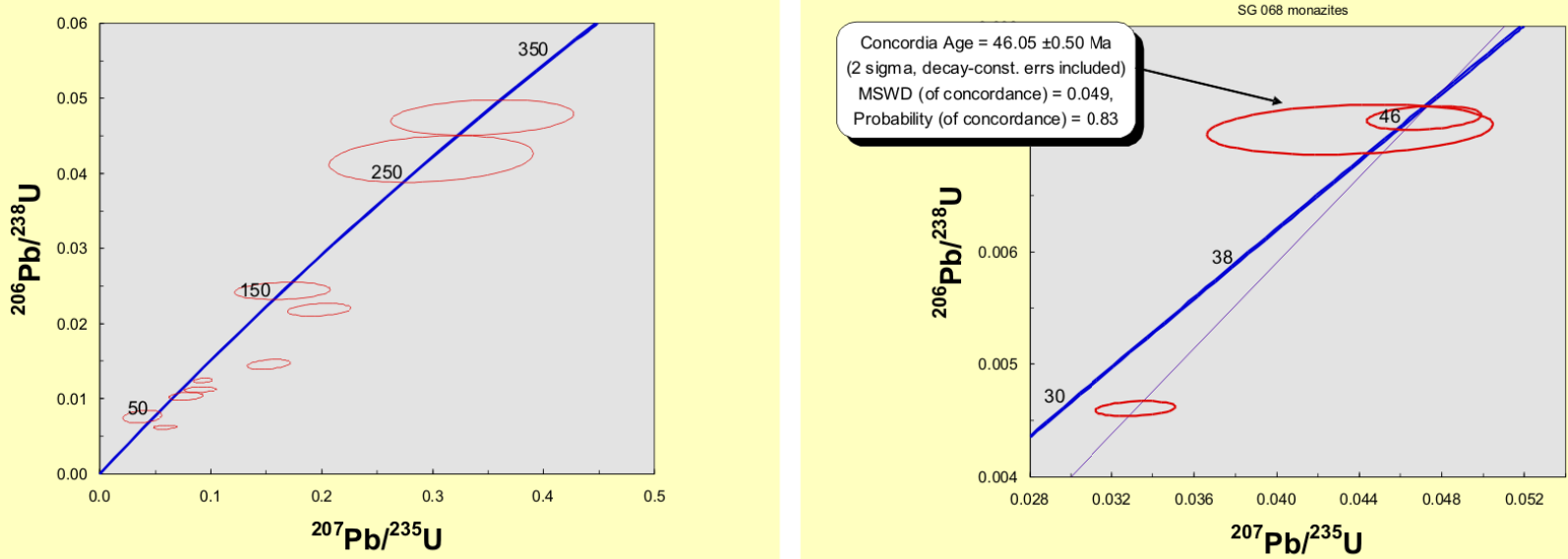

Figure 3-59. Results from single zircon U-PB LA-ICPMS dating for sample SG 068 
a

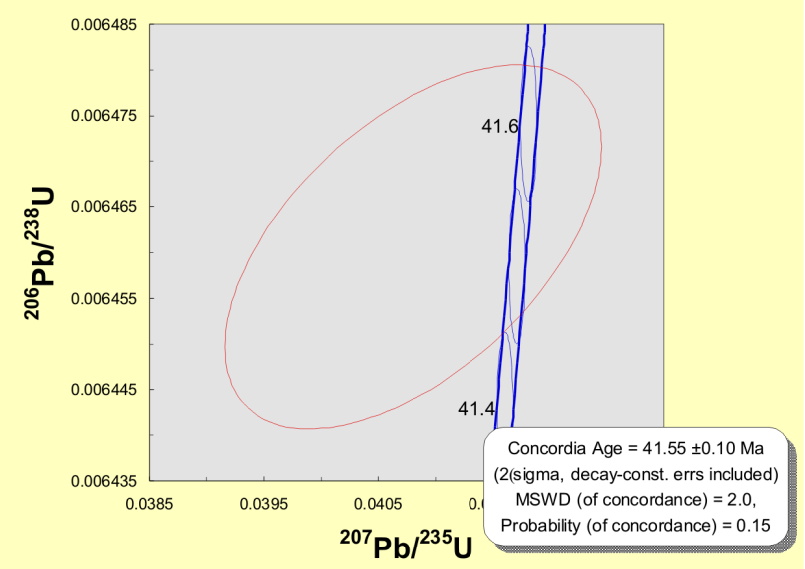

c

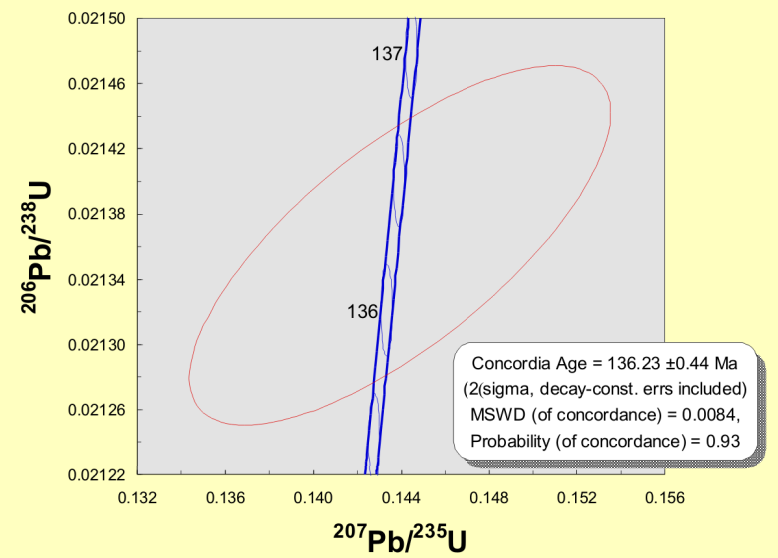

b

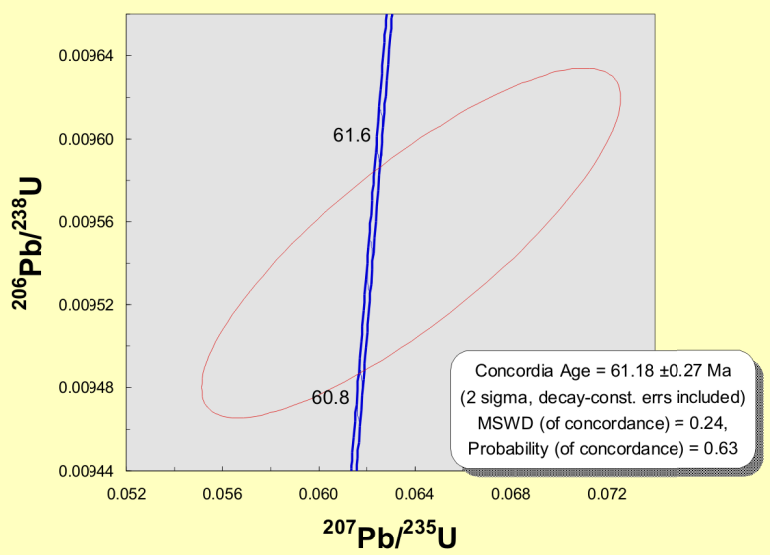

d

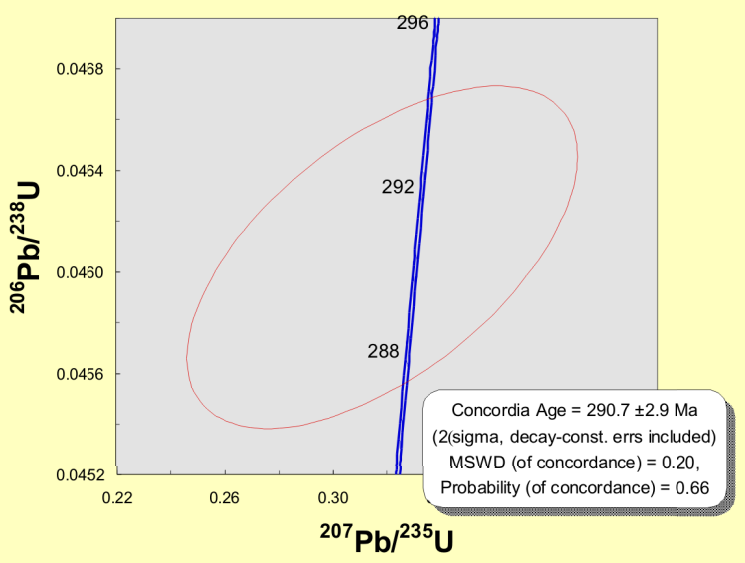

Figure 3-58. Results from single zircon U-Pb ID-TIMS dating for sample SG 068

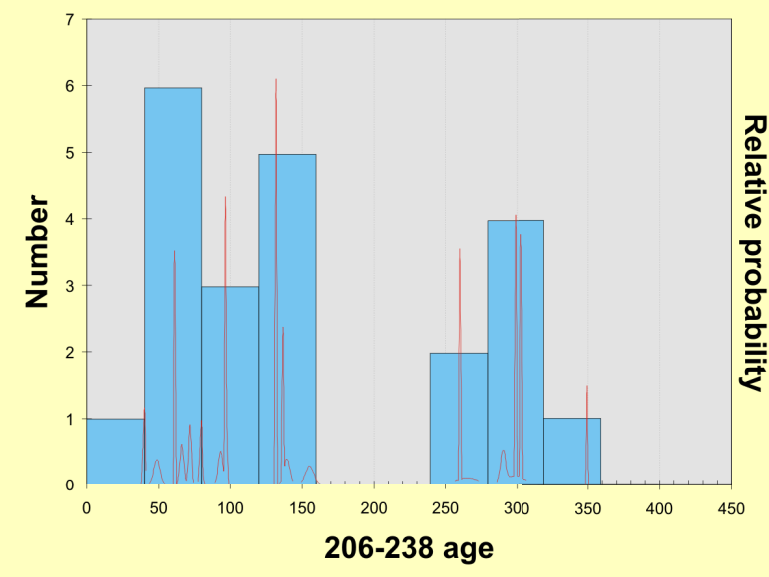

Figure 3-60. Combined results from single zircon U-PB ID-TIMS and LA-ICPMS dating for sample SG 068 


\section{SG 069 - Qz-diorite dike}

The studied dike cut Triassic flysch sediments near the village of Zvezda. Three chemically abraded zircons analyzed by ID-TIMS all cross the concordia line and single zircon concordia ages can be calculated at $\sim 52,97$ and $281 \mathrm{Ma}$ for each analysis (Figure 3-61). The zircon with the youngest age has high $\mathrm{Pb}$ content and anomalously low ${ }^{206} \mathrm{~Pb}^{*} / 204 \mathrm{~Pb}$ ratios and was probably contaminated with common $\mathrm{Pb}$.

The measurements do not lie on a discordia line and the crystallization age of the dike cannot be determined. LA-ICPMS data for 9 zircons indicate the presence of a 250-350 Ma old inherited component (Figure 3-62). One zircon has a ${ }^{206} \mathrm{~Pb} /{ }^{238} \mathrm{U}$ age of $71 \mathrm{Ma}$, while the youngest grain is concordant at $53.71 \pm 0.69$ $\mathrm{Ma}$, two sigma errors. This age alone cannot be confidently considered as a crystallization age of the sample, but nevertheless indicates, in a similar way as data for sample SG 068 that compared to the other regions of Eastern Srednogorie, the rocks from the East Balkan region were affected by some younger, post-Late Cretaceous event.

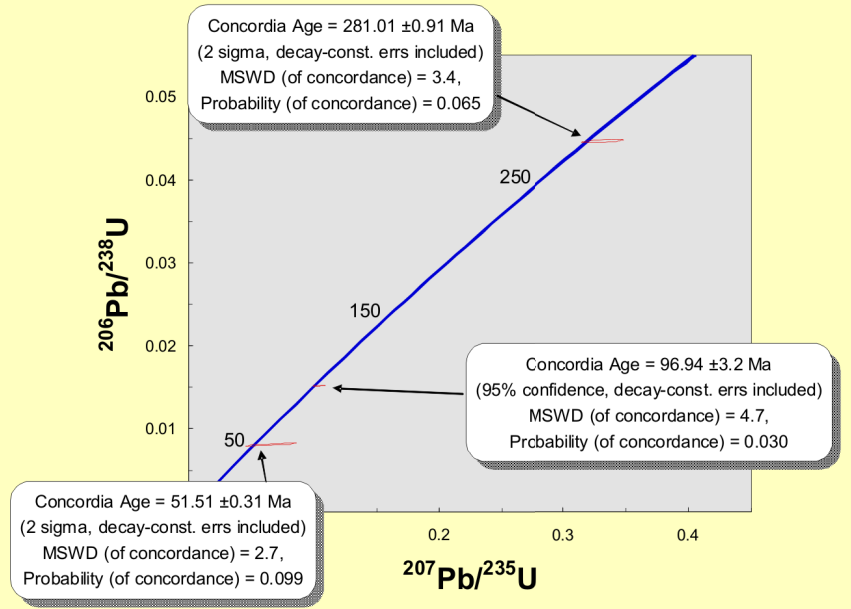

Figure 3-61. Results from single zircon U-PB ID-TIMS dating for sample SG 069

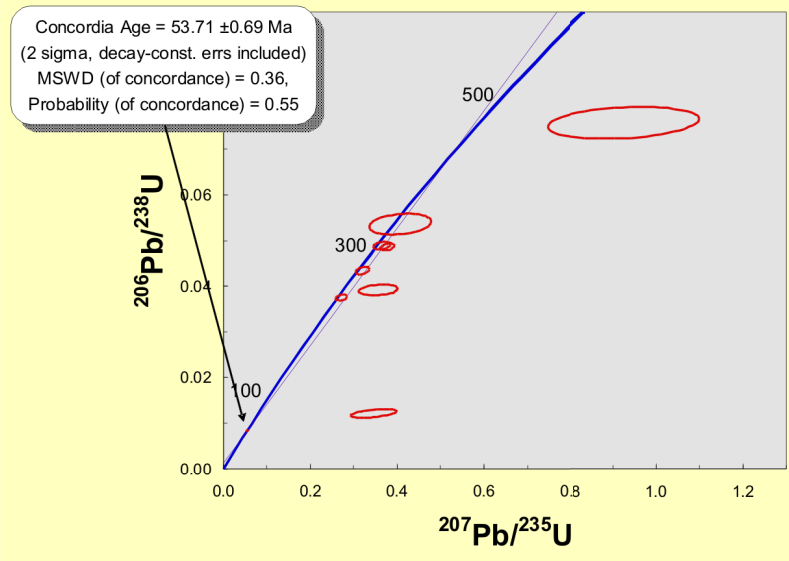

Figure 3-62. Results from single zircon U-PB LA-ICPMS dating for sample SG 069

\section{SG 093 - Andesite, Zaimchevo}

This sample is collected between the villages of Zaimchevo and Kamnjak. The three non-abraded zircons dated by ID-TIMS lie on a discordia with an upper intercept of $577 \pm 57 \mathrm{Ma}$ and a lower intercept at $258 \pm 15 \mathrm{Ma}$, with a MSWD of 0.13 (Figure 3-63a). The youngest grain alone yields a concordia age of 270.65 $\pm 0.69 \mathrm{Ma}, 2$ sigma errors, reflecting assimilation of Variscan basement by the Late Cretaceous magmas.

a

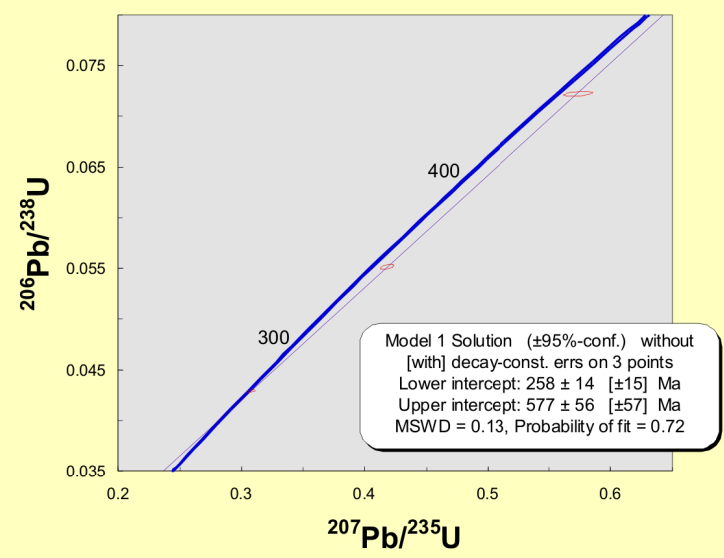

b

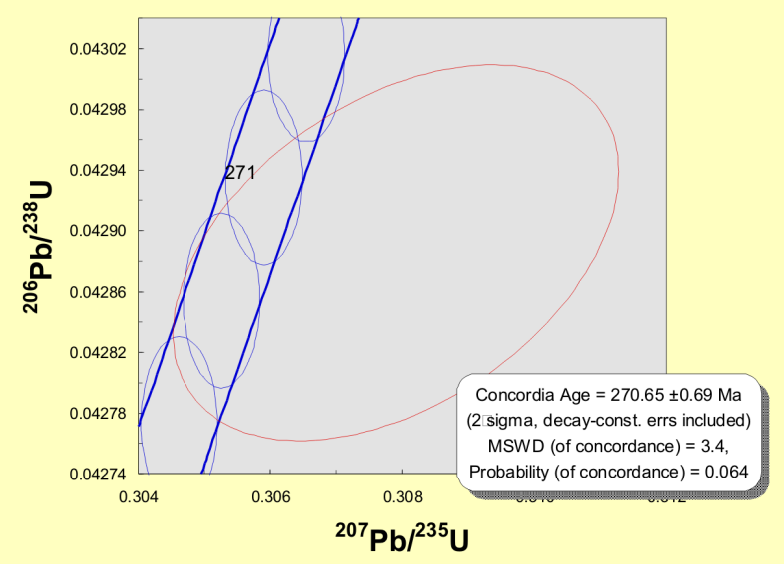

Figure 3-63. Results from single zircon U-PB ID-TIMS dating for sample SG 093 


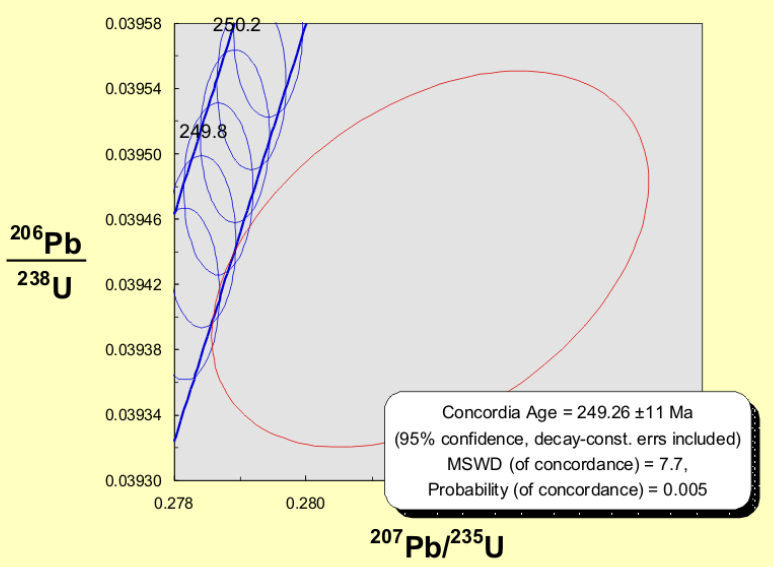

Figure 3-64. Results from single zircon U-PB ID-TIMS dating for sample SG 107

\section{SG 107 - Rhyolite, Karandila}

A single zircon dated by ID-TIMS shows slight discordance, but crosses the concordia band and gives and age of 249.26 $\pm 1 \mathrm{Ma}$ at the $95 \%$ confidence limit (Figure 3-64). Additional analyses are needed to constrain the age of the rock. 


\section{Appendix 4. CL and BSE images with LA-ICPMS ${ }^{206} \mathrm{~Pb}-{ }^{238} \mathrm{U}$ ages}

Cathodoluminiscence (CL) and backscattered images (BSE) of zircons, showing the location and diameter of laser craters (solid circles) and the calculated ${ }^{206} \mathrm{~Pb}_{-}{ }^{238} \mathrm{U}$ age with corresponding $2 \sigma$ uncertainties. The grain number (lower right) and lab number of the LA-ICPMS dating analyses (e.g. Ar01c04) are also provided, as a reference to Appendix 2. Samples are arranged alphabetically, starting with AvQ samples (pages 1-6) followed by SG-samples (pages 7-19) and sample St 25 (page 19).

AvQ 046
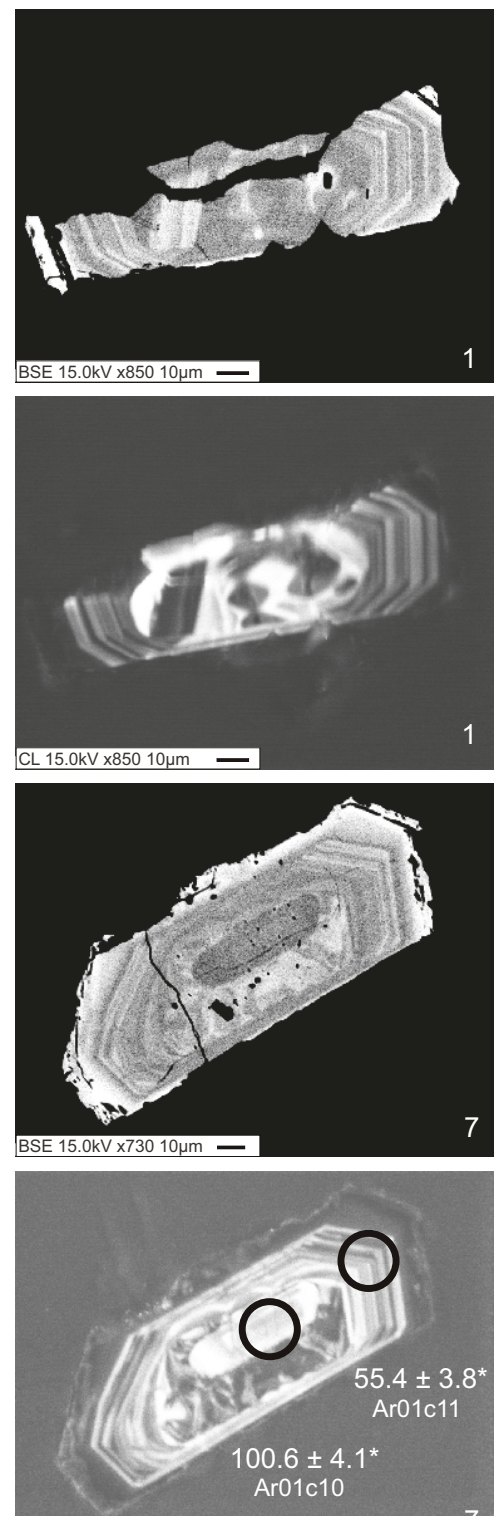
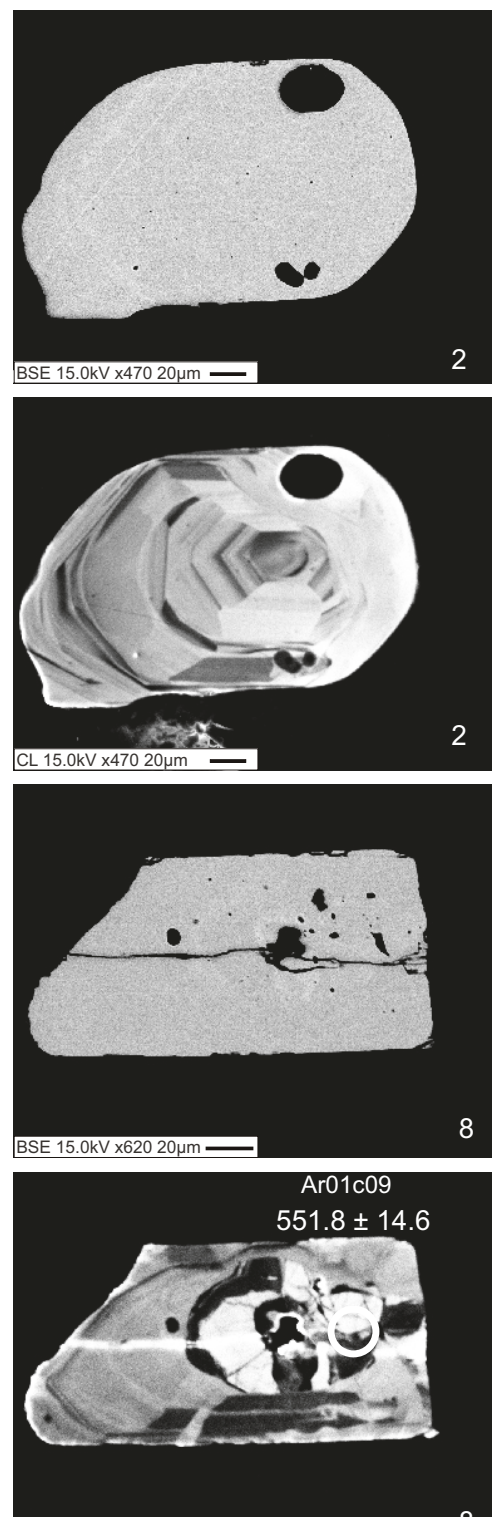
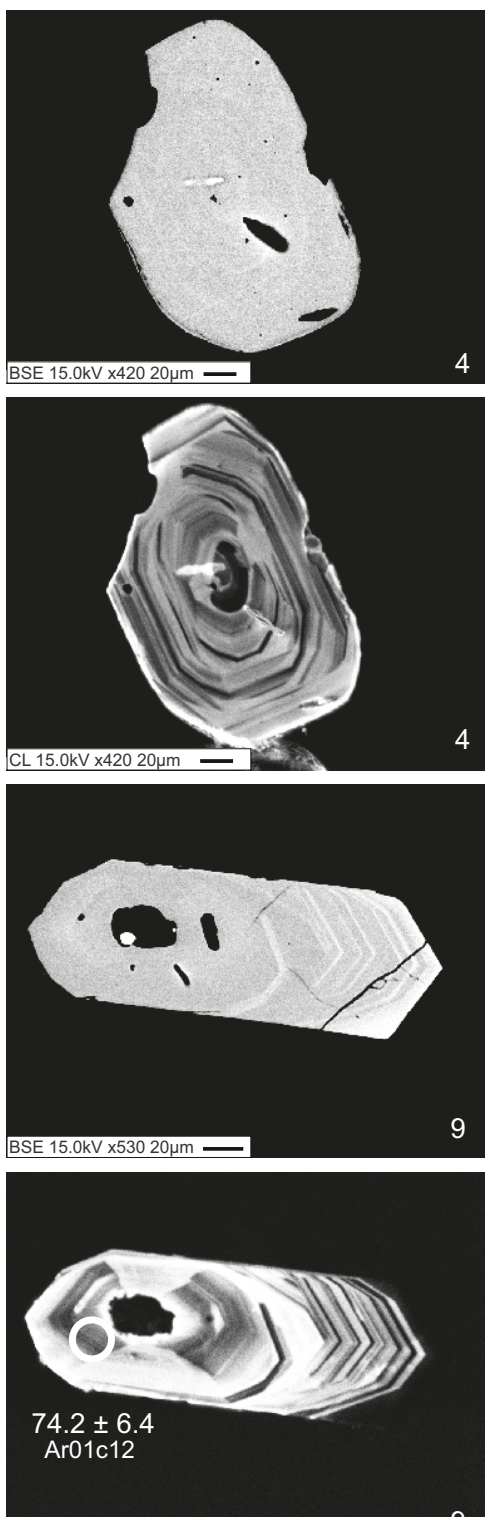
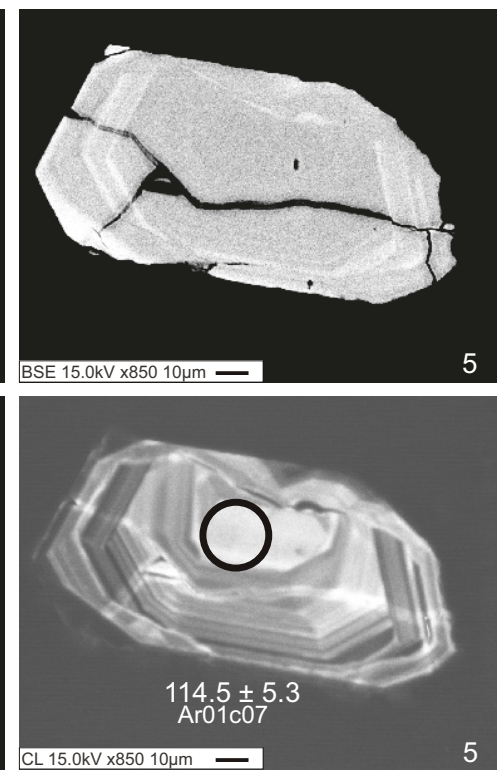

$\mathrm{CL} 15.0 \mathrm{kV} \times 85010 \mu \mathrm{m}$ 

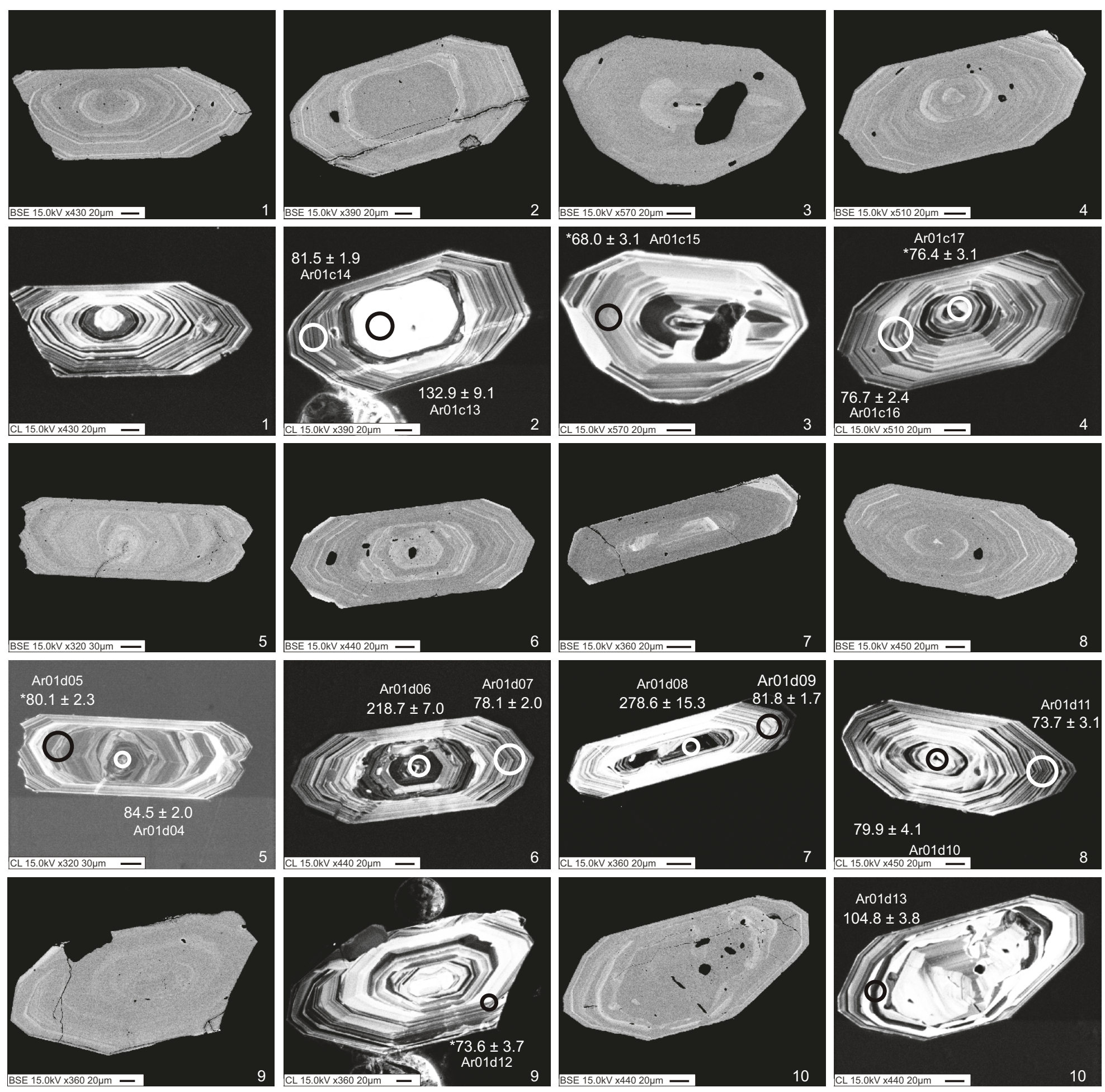

AvQ 050
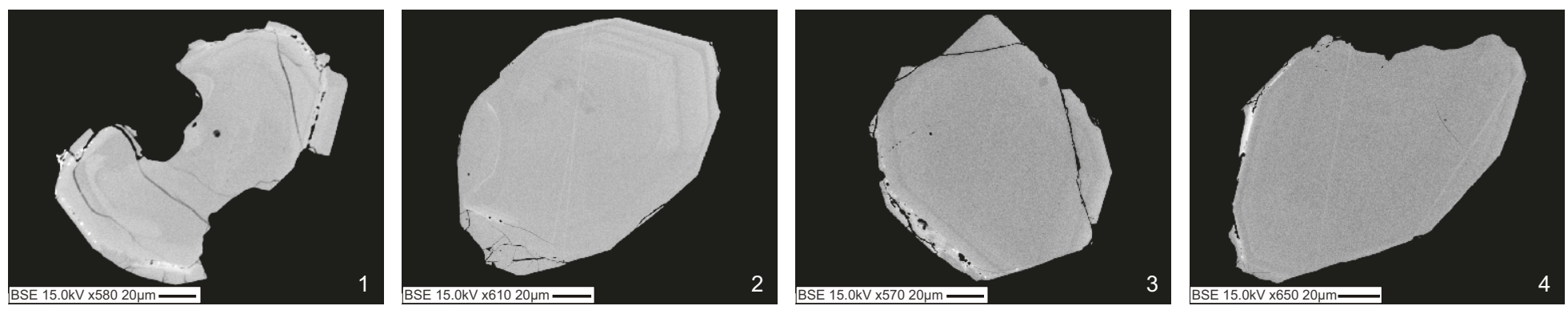


\section{AvQ 050-continued}
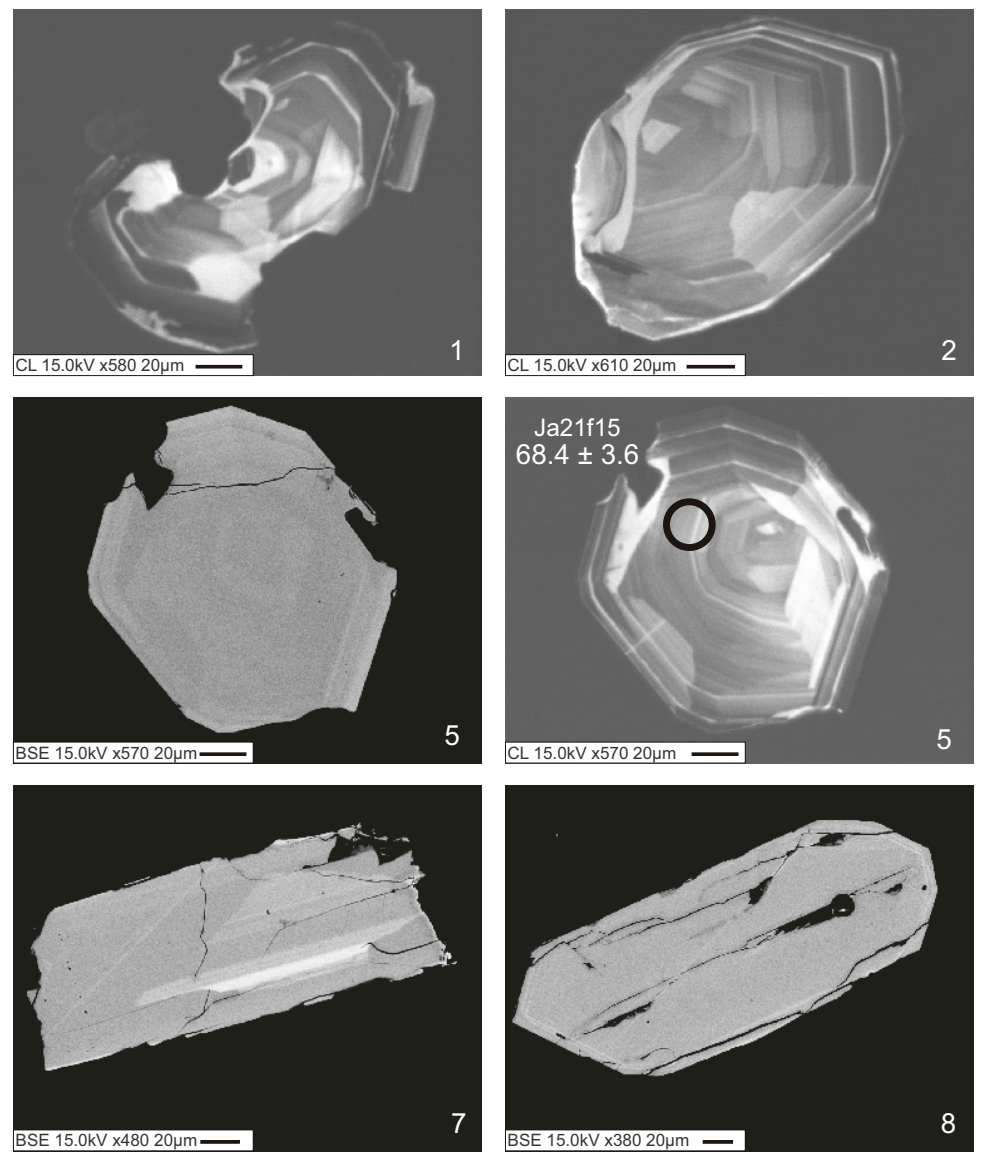
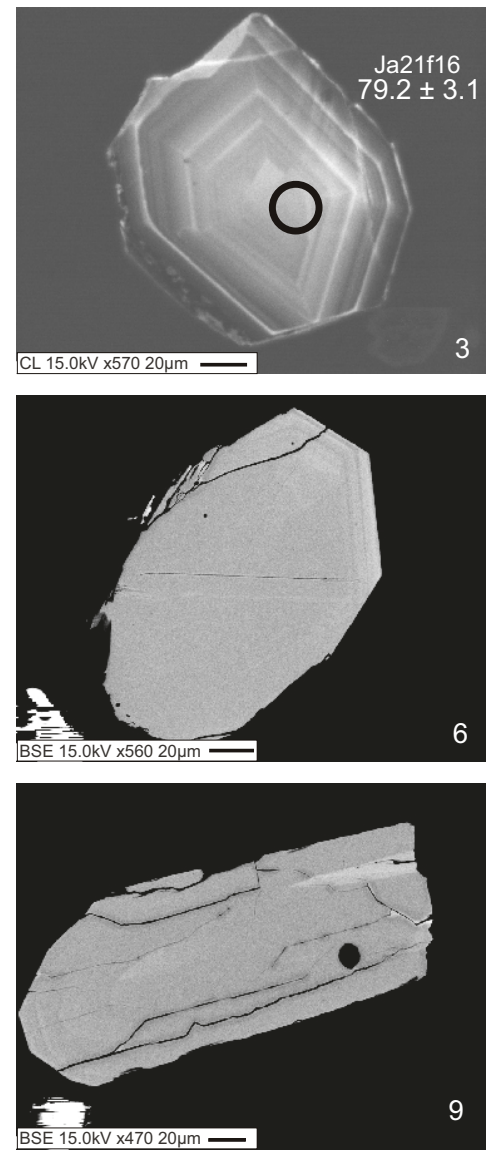

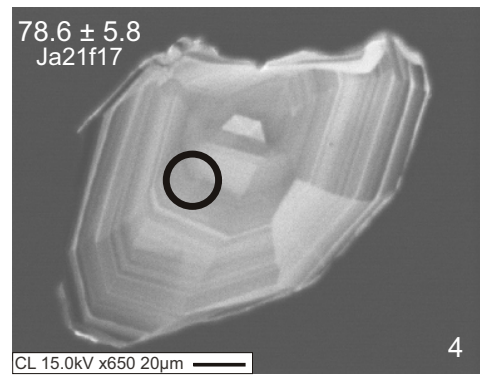

AvQ 051
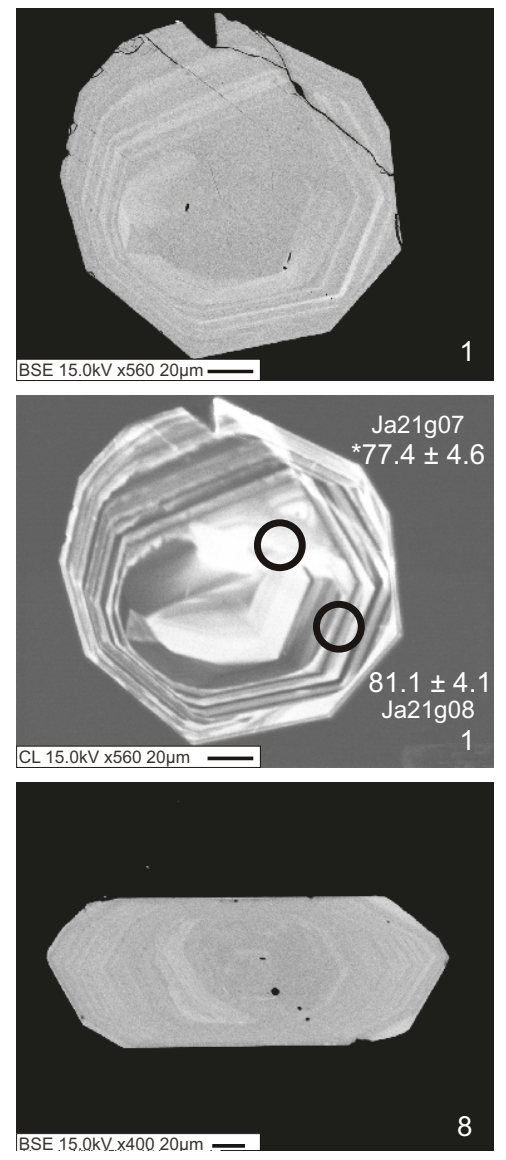

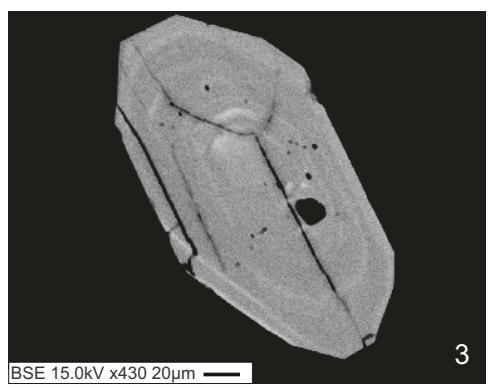

3
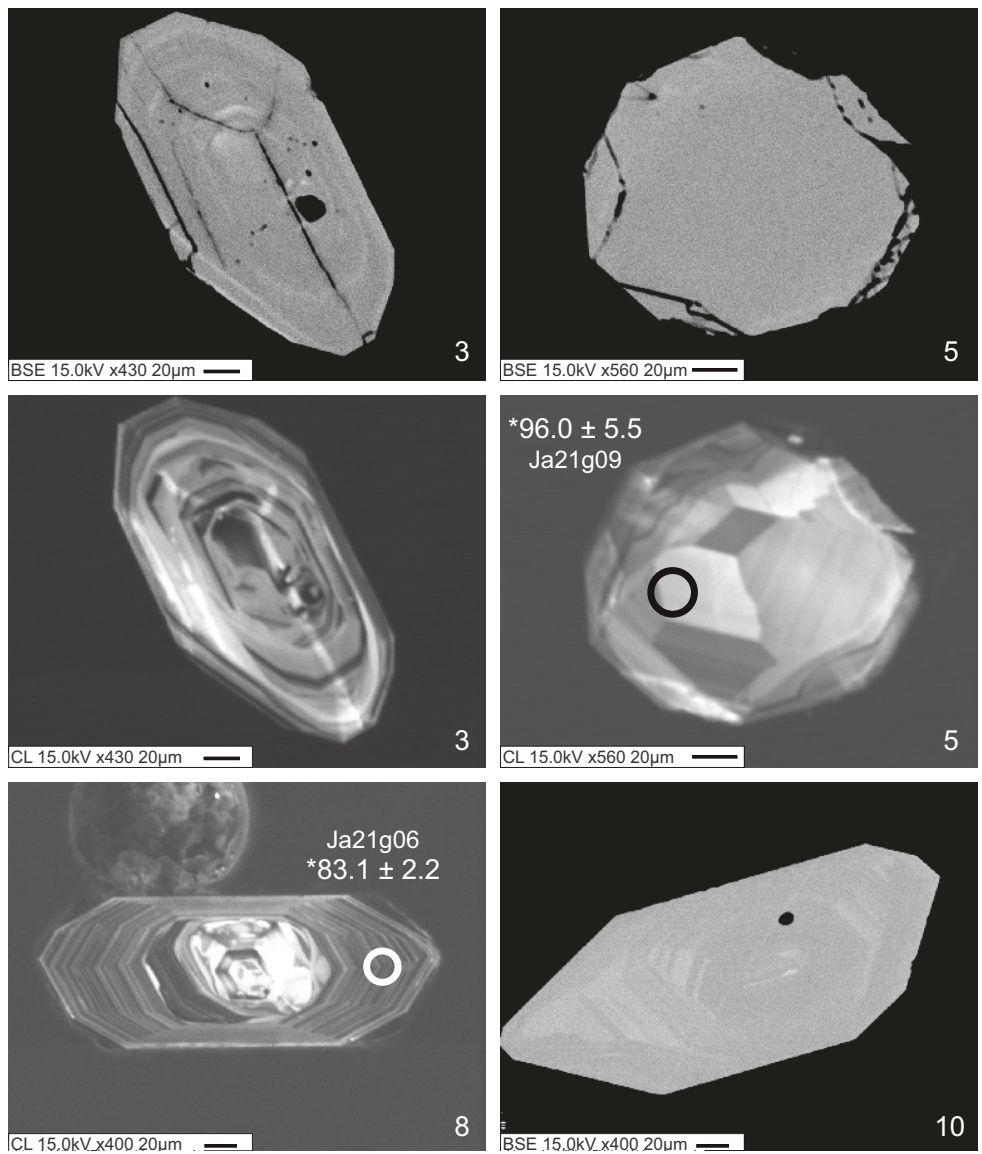
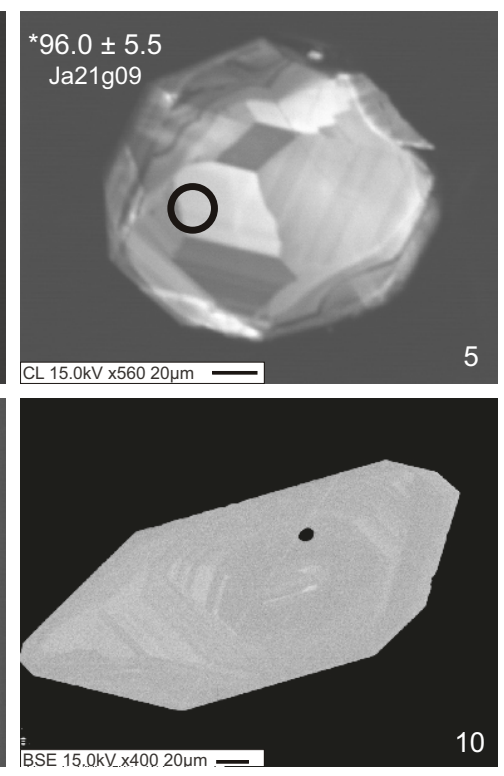
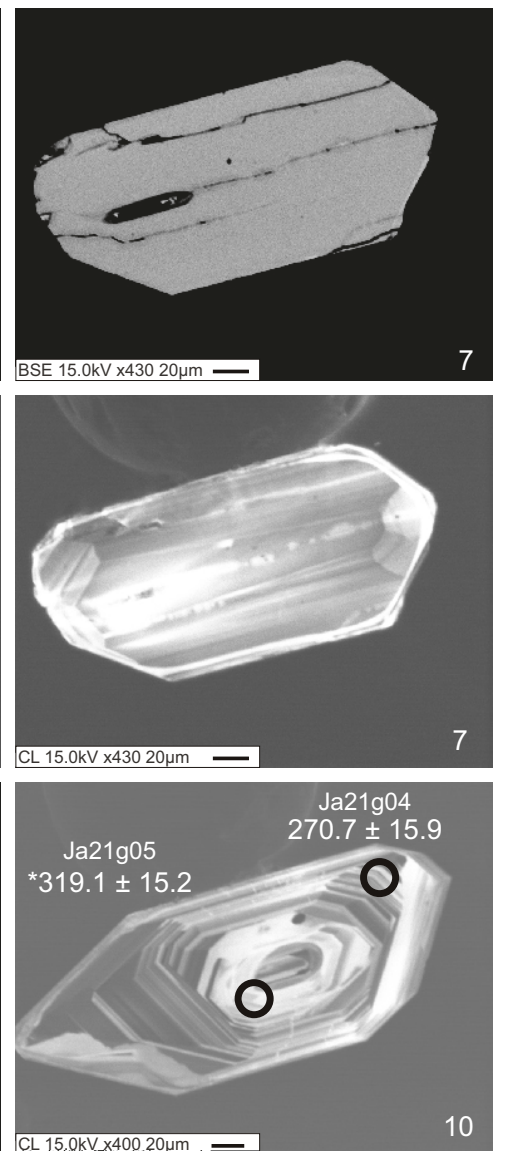


\section{AvQ 054}
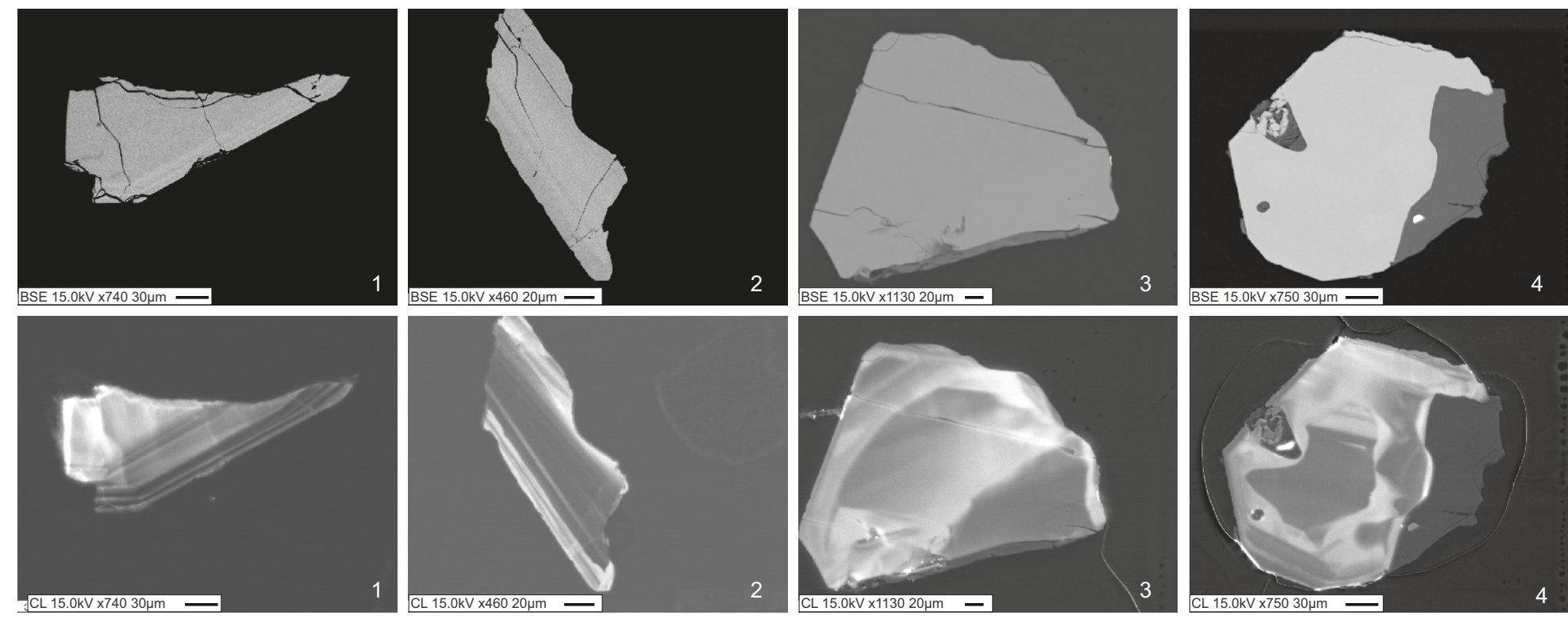

(3)
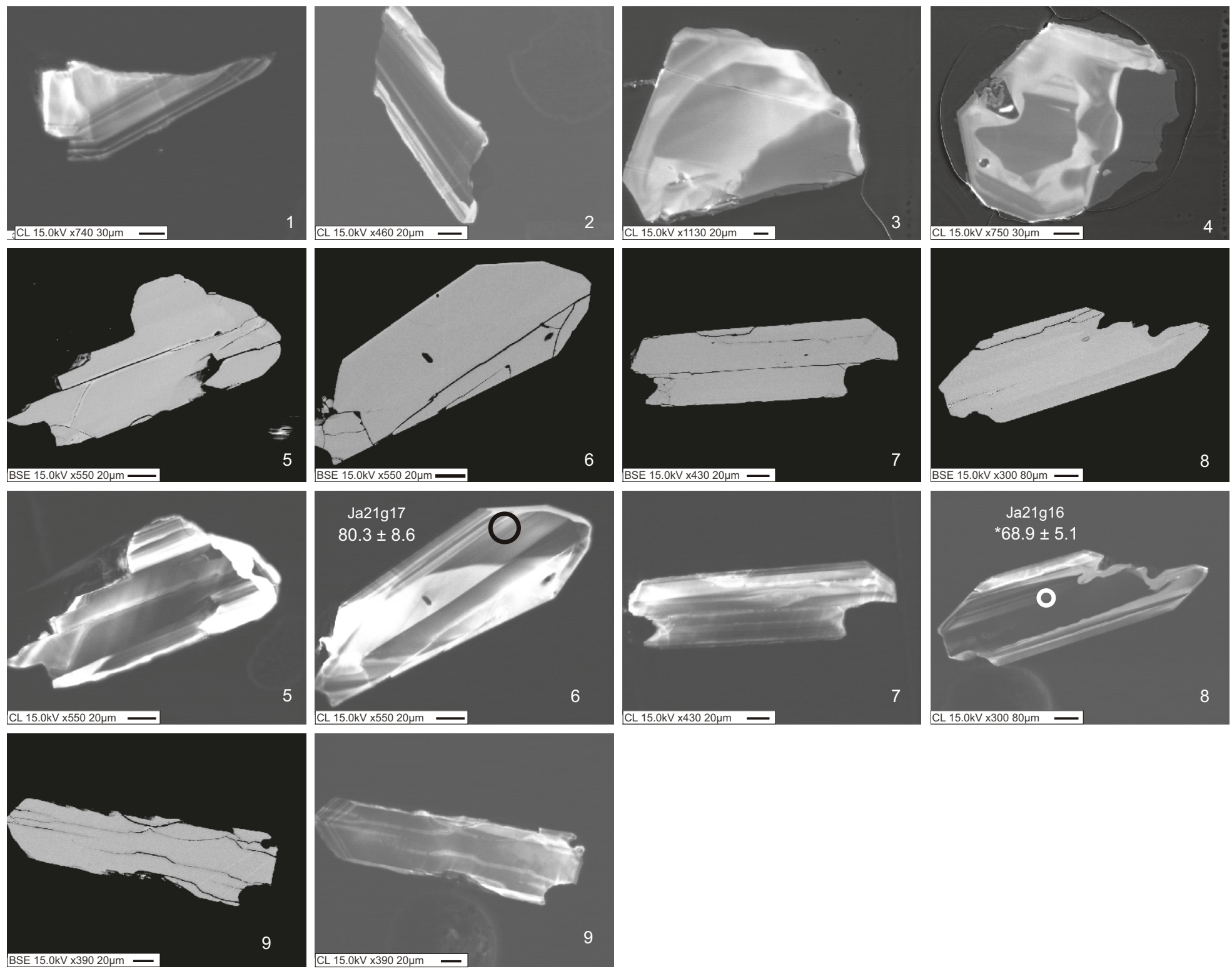

AvQ 055
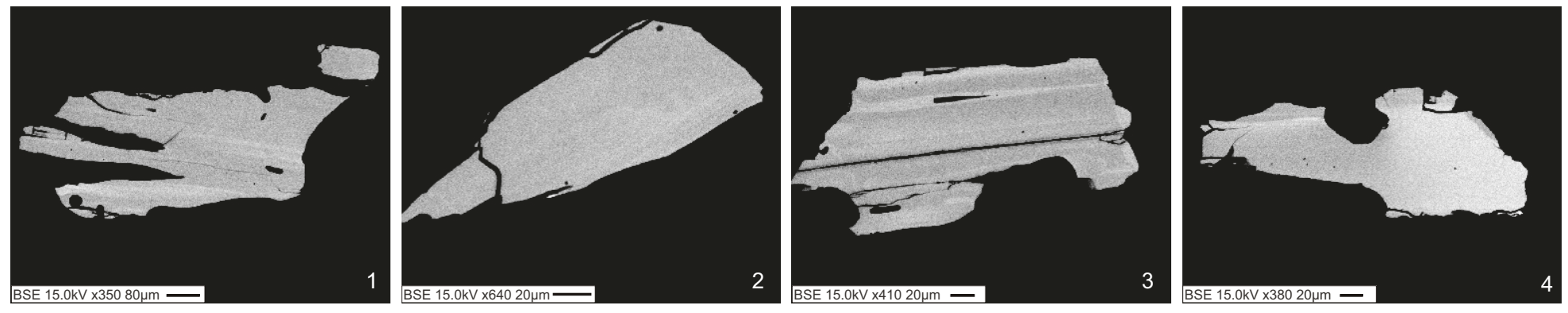


\section{AvQ 055-continued}
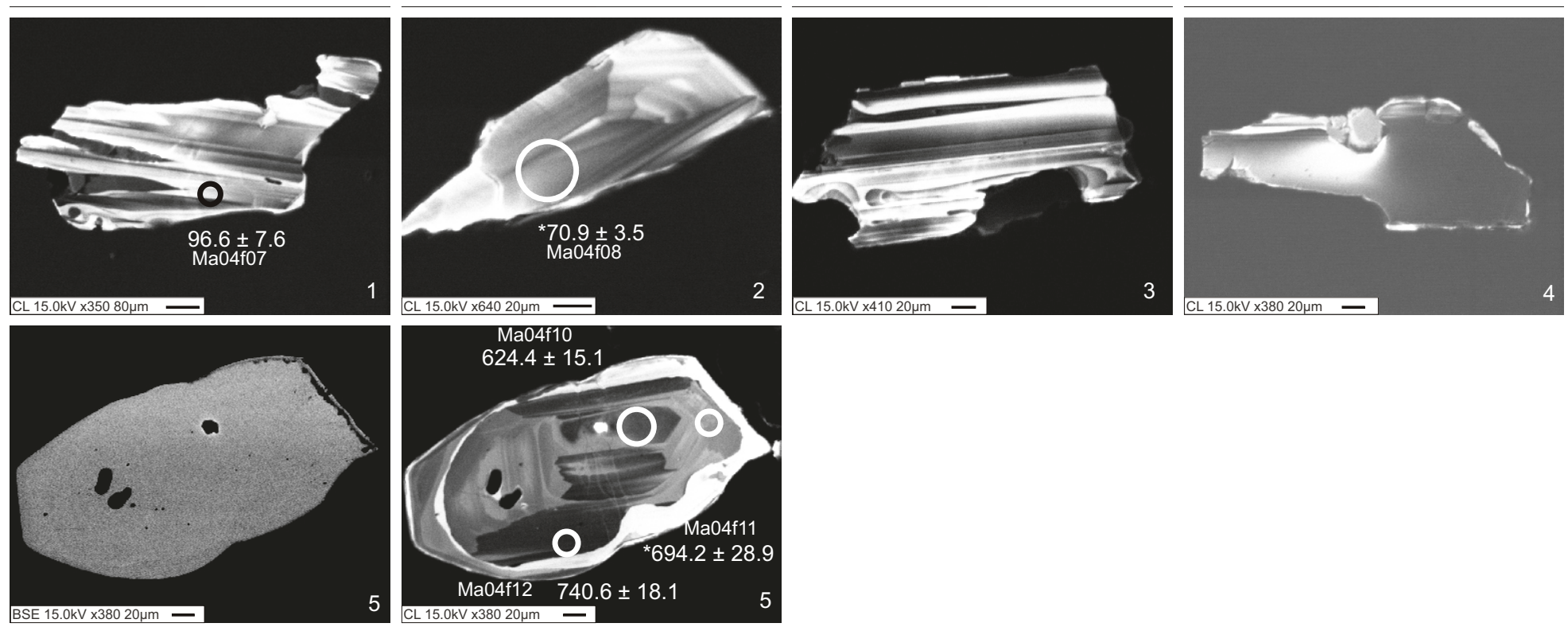

\section{AvQ 057}
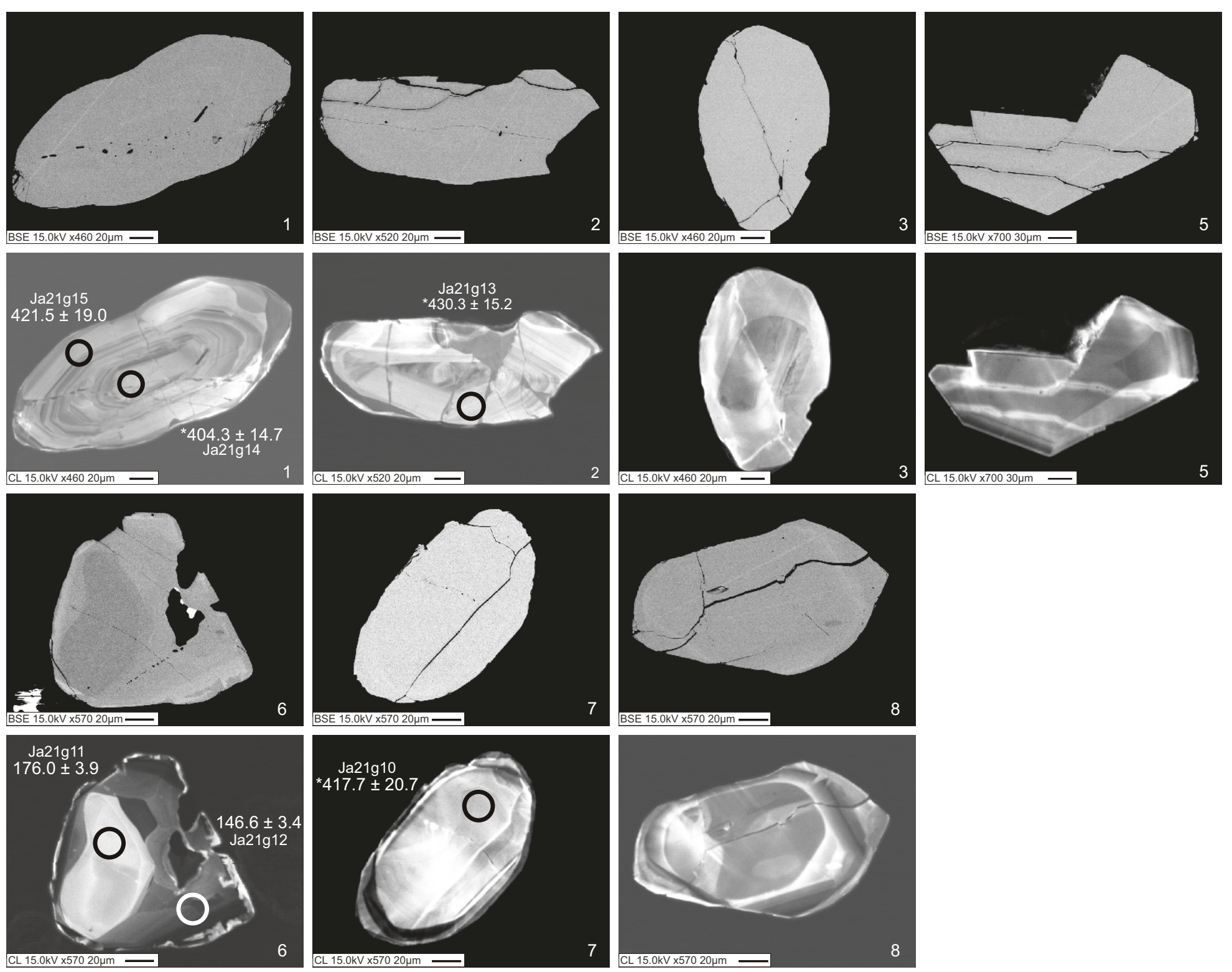


\section{AvQ 058}
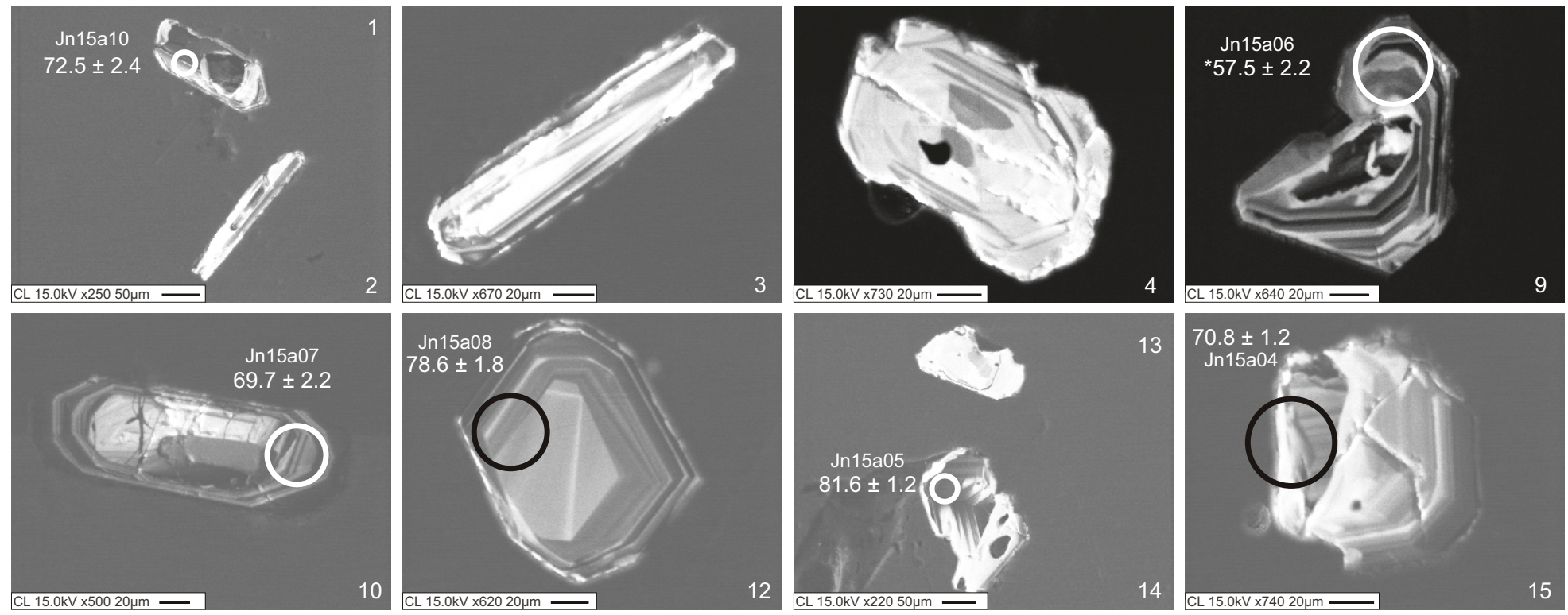

\section{AvQ 142}
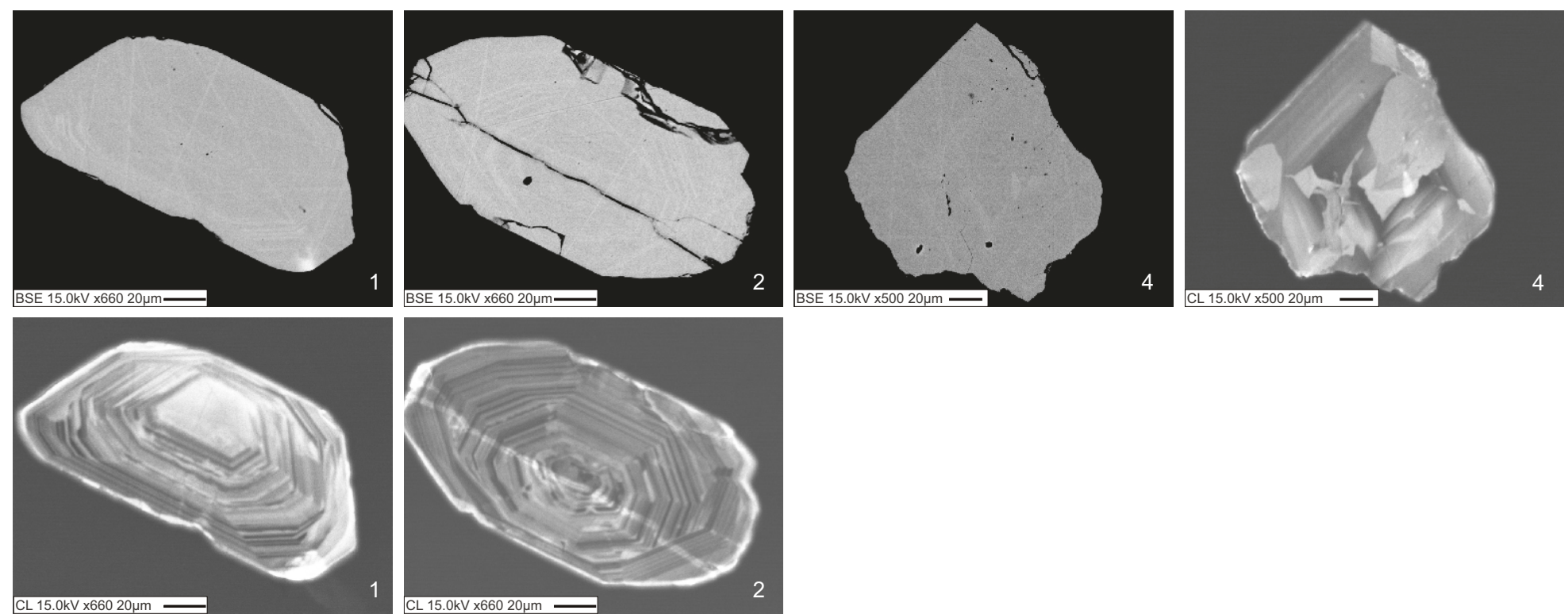


\section{SG 001}
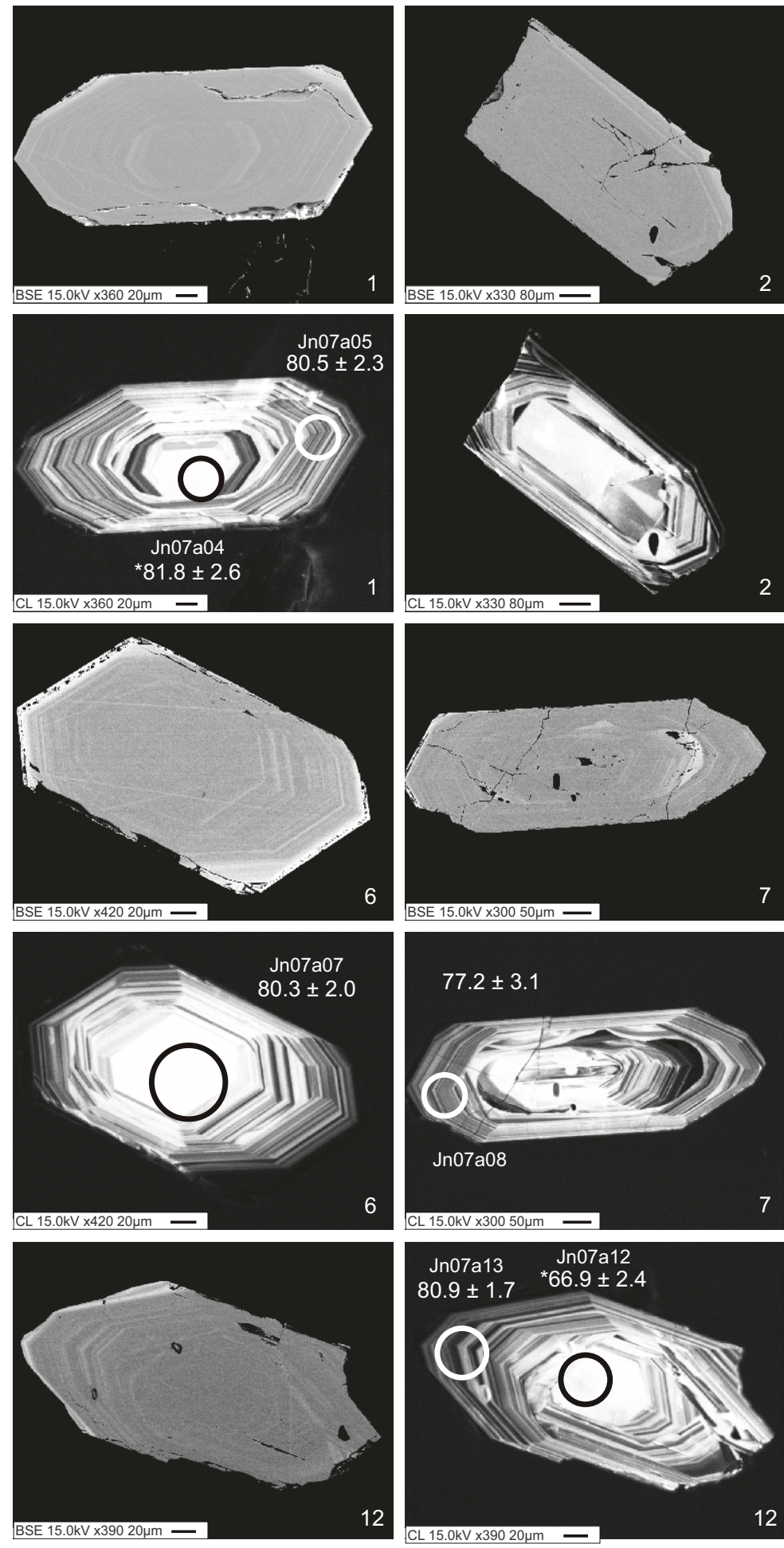
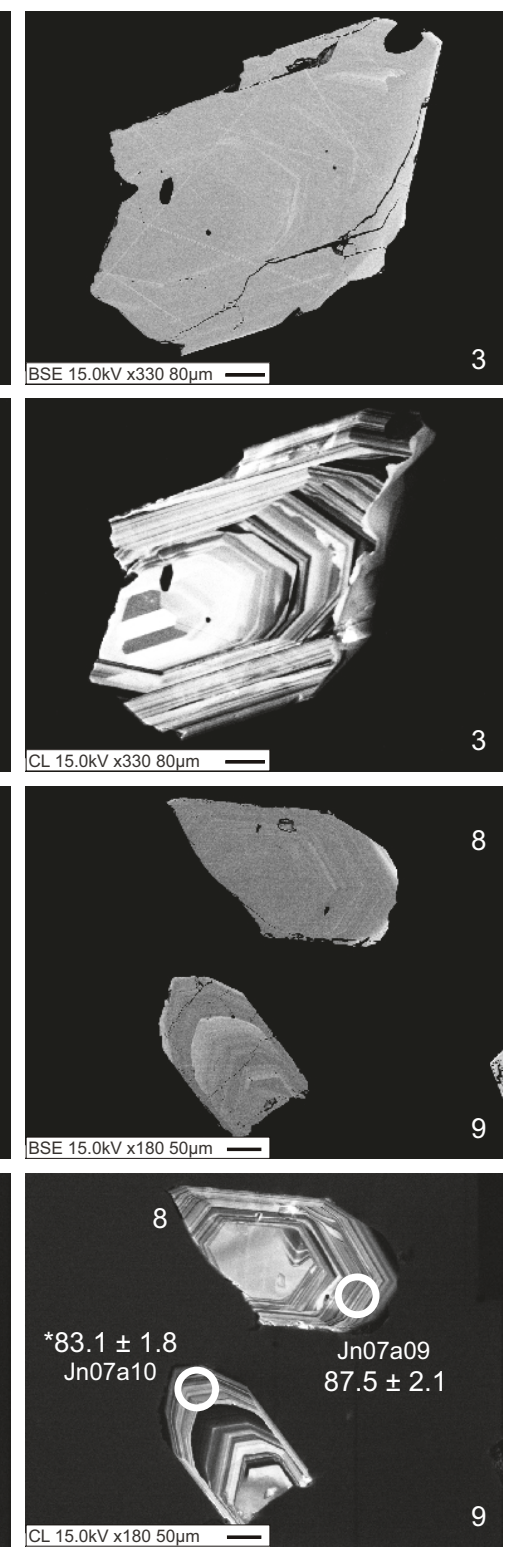

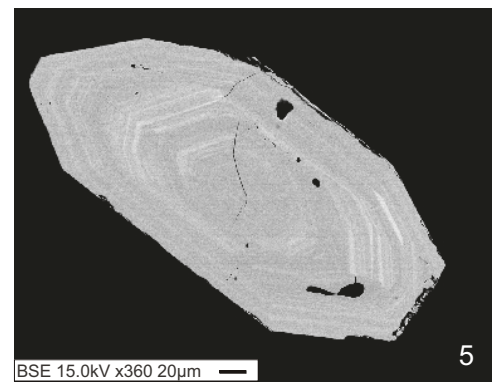

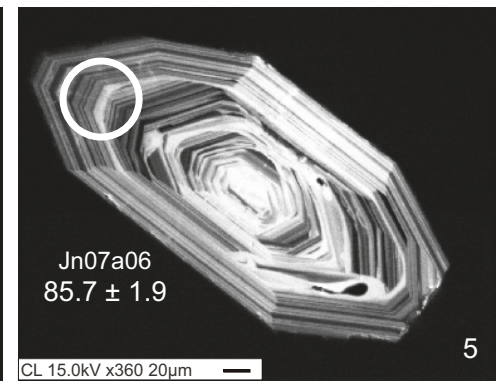
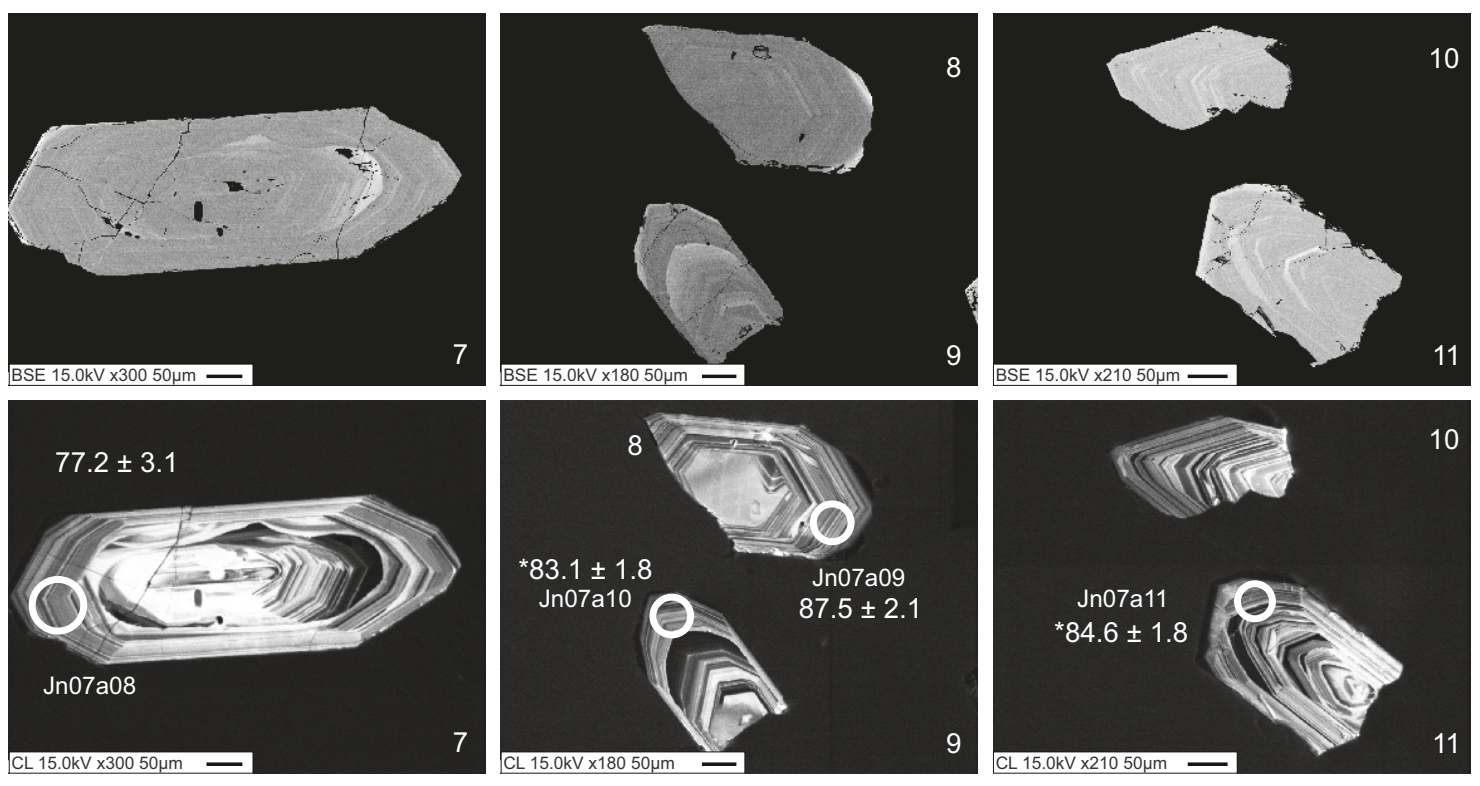

\section{SG 011}
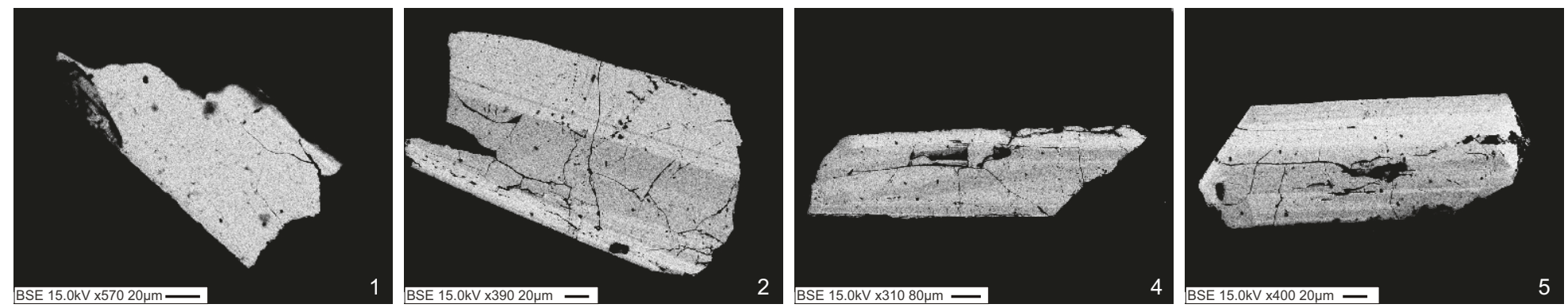

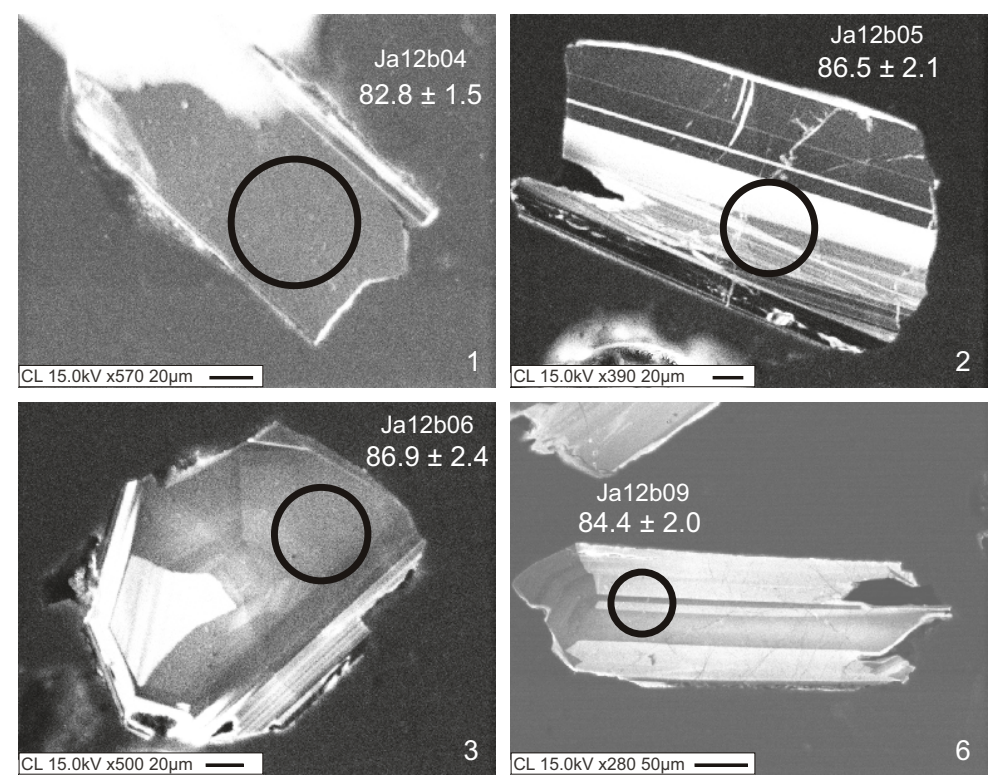

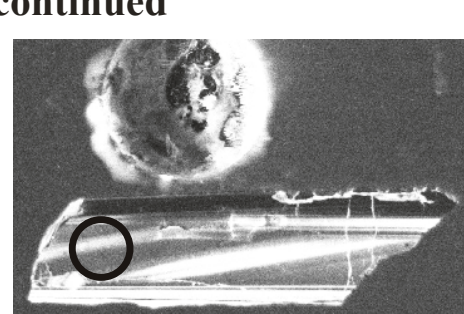

$\mathrm{Ja} 12 \mathrm{~b} 07$

$79.2 \pm 2.3^{\circ}$

CL $15.0 \mathrm{kV} \times 31080 \mu \mathrm{m}$

$\mathrm{Ja} 12 \mathrm{~b} 08$

$94.5 \pm 1.7$

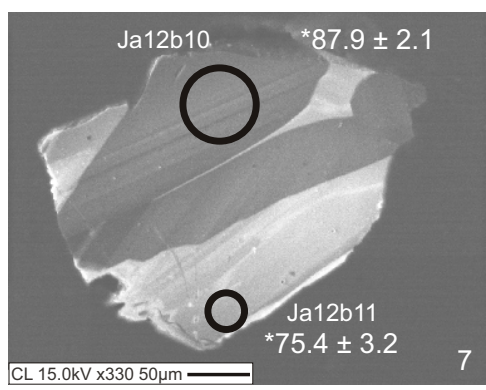

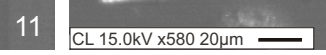

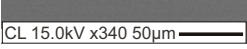
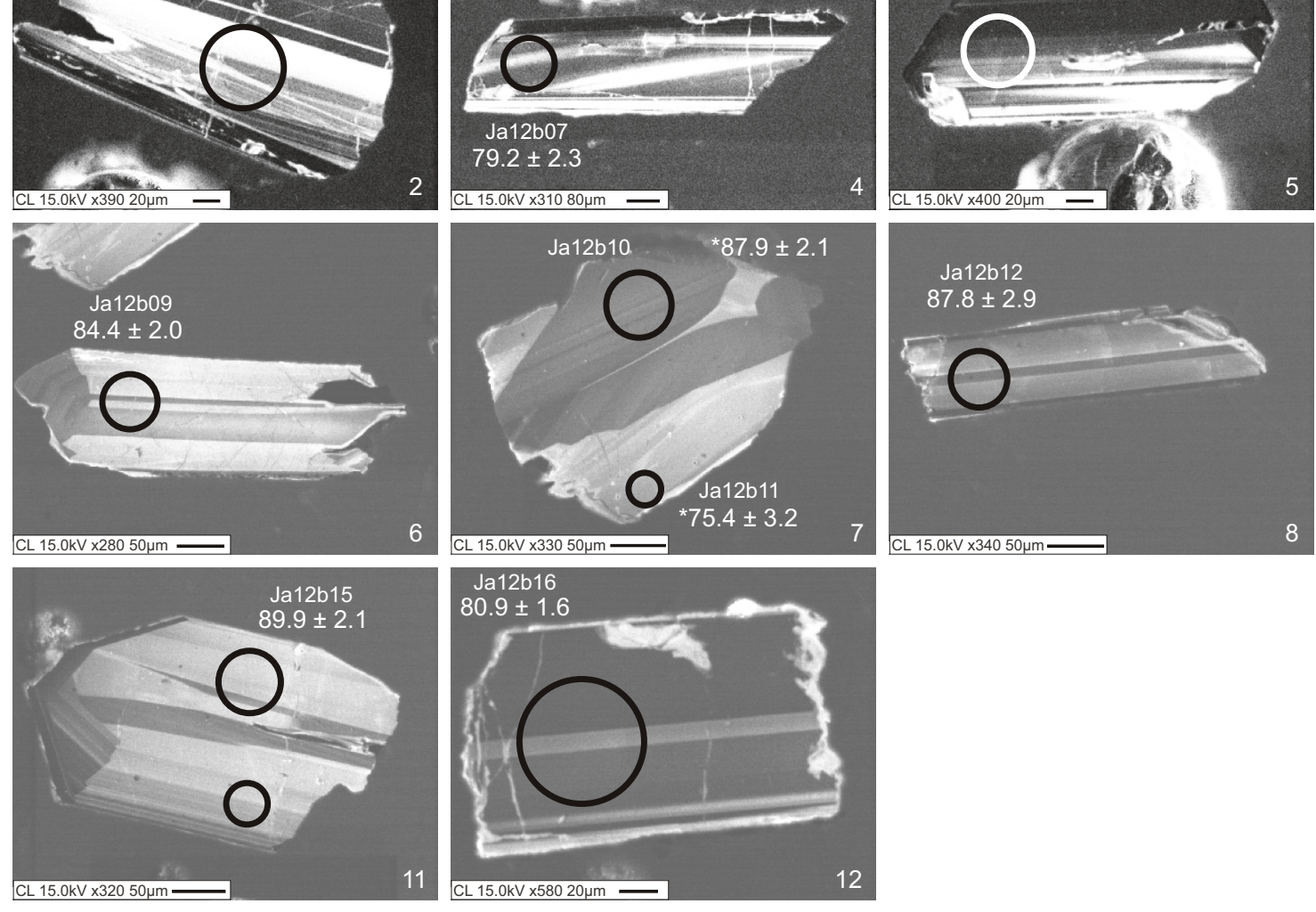
CL $15.0 \mathrm{kV} \times 40020 \mu \mathrm{m}-\mathrm{P}$ : 15

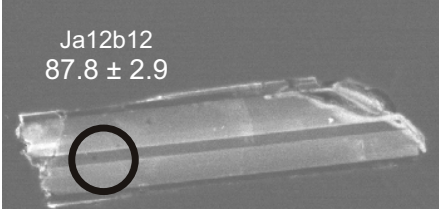

SG 028
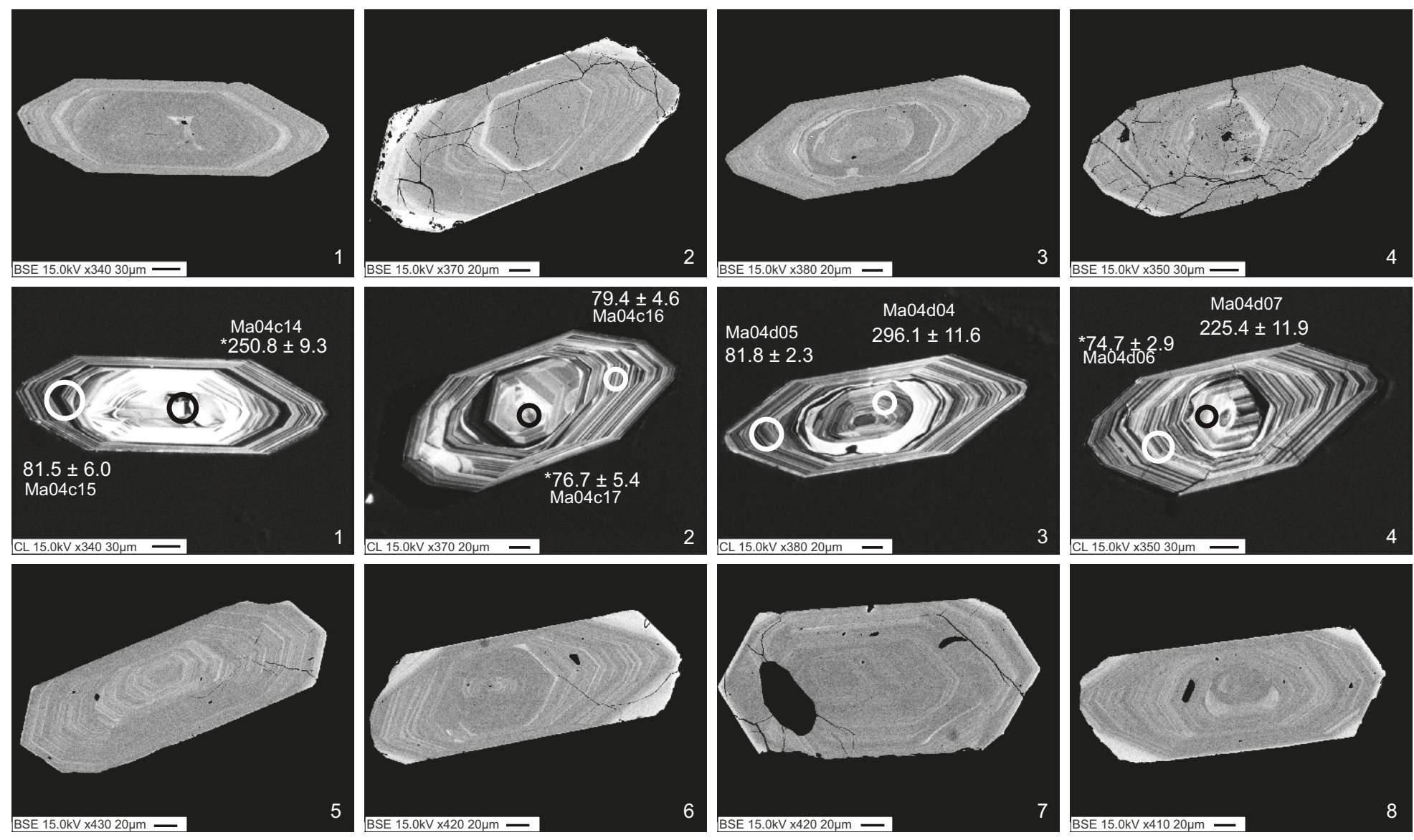


\section{SG 028-continued}
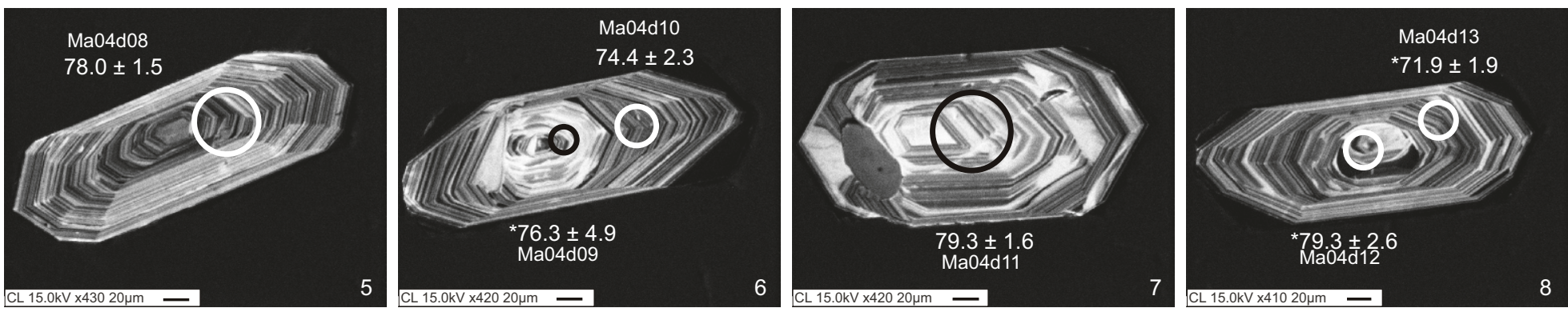

SG 040
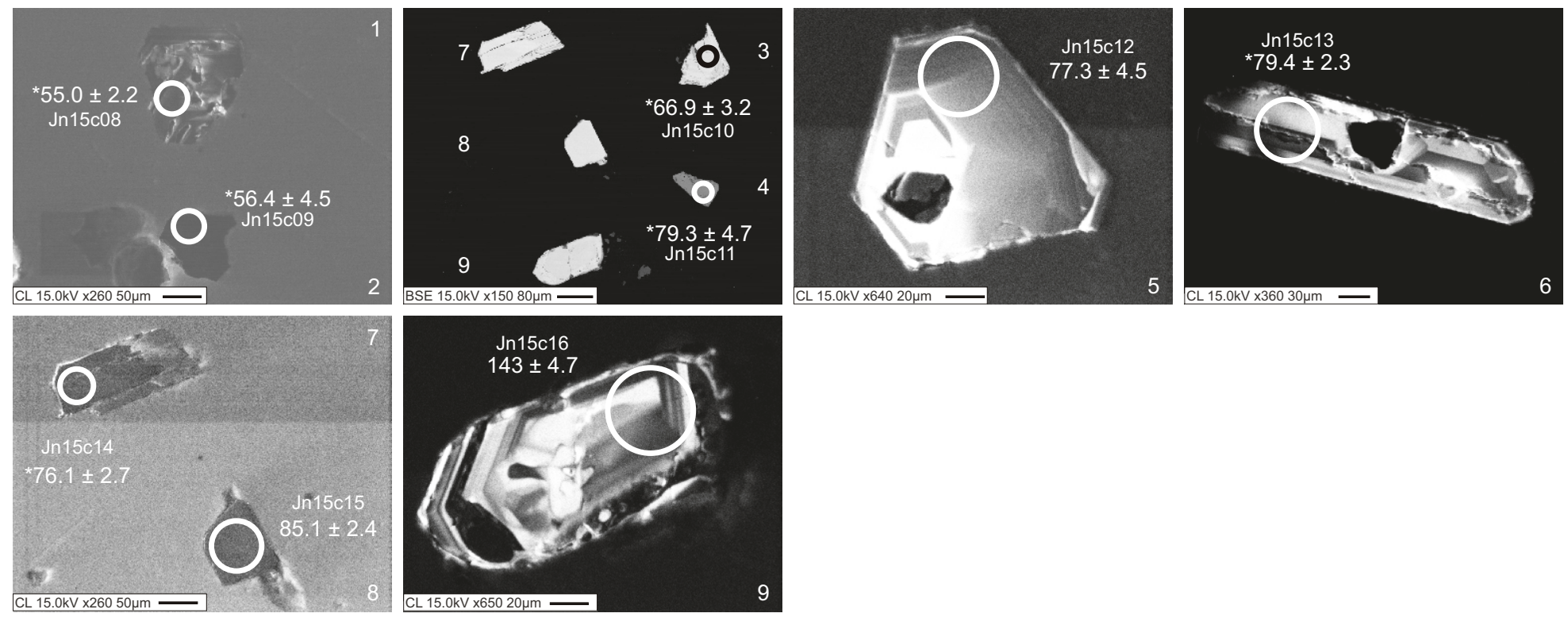

SG 041
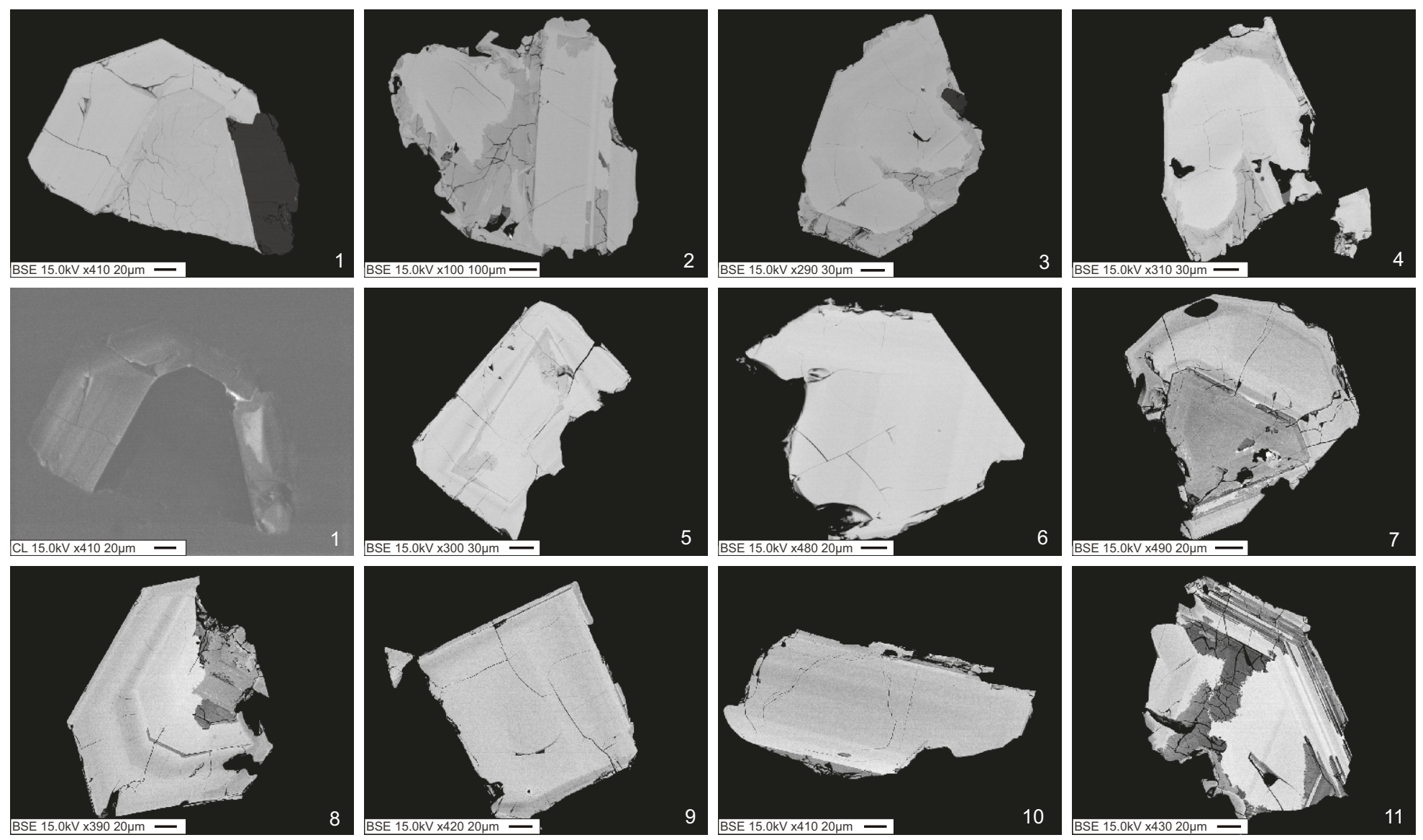


\section{SG 041-continued}
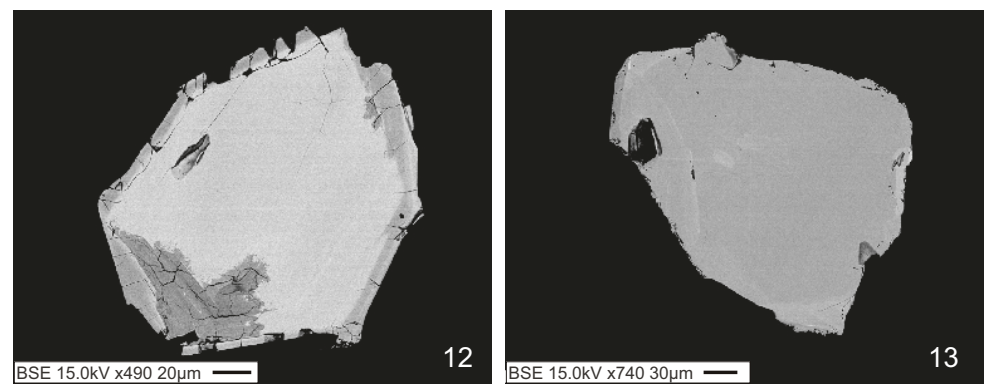

SG 044
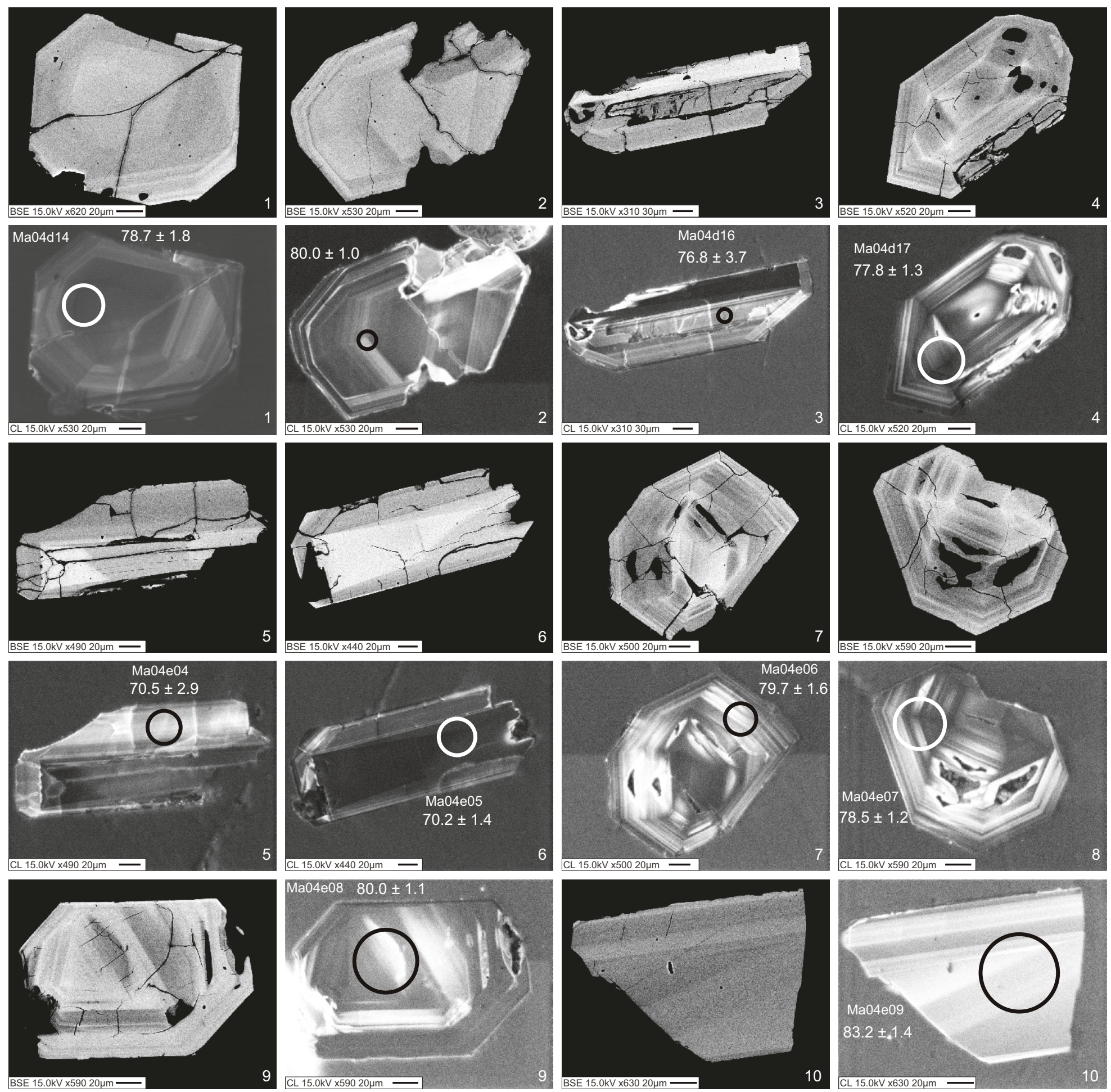

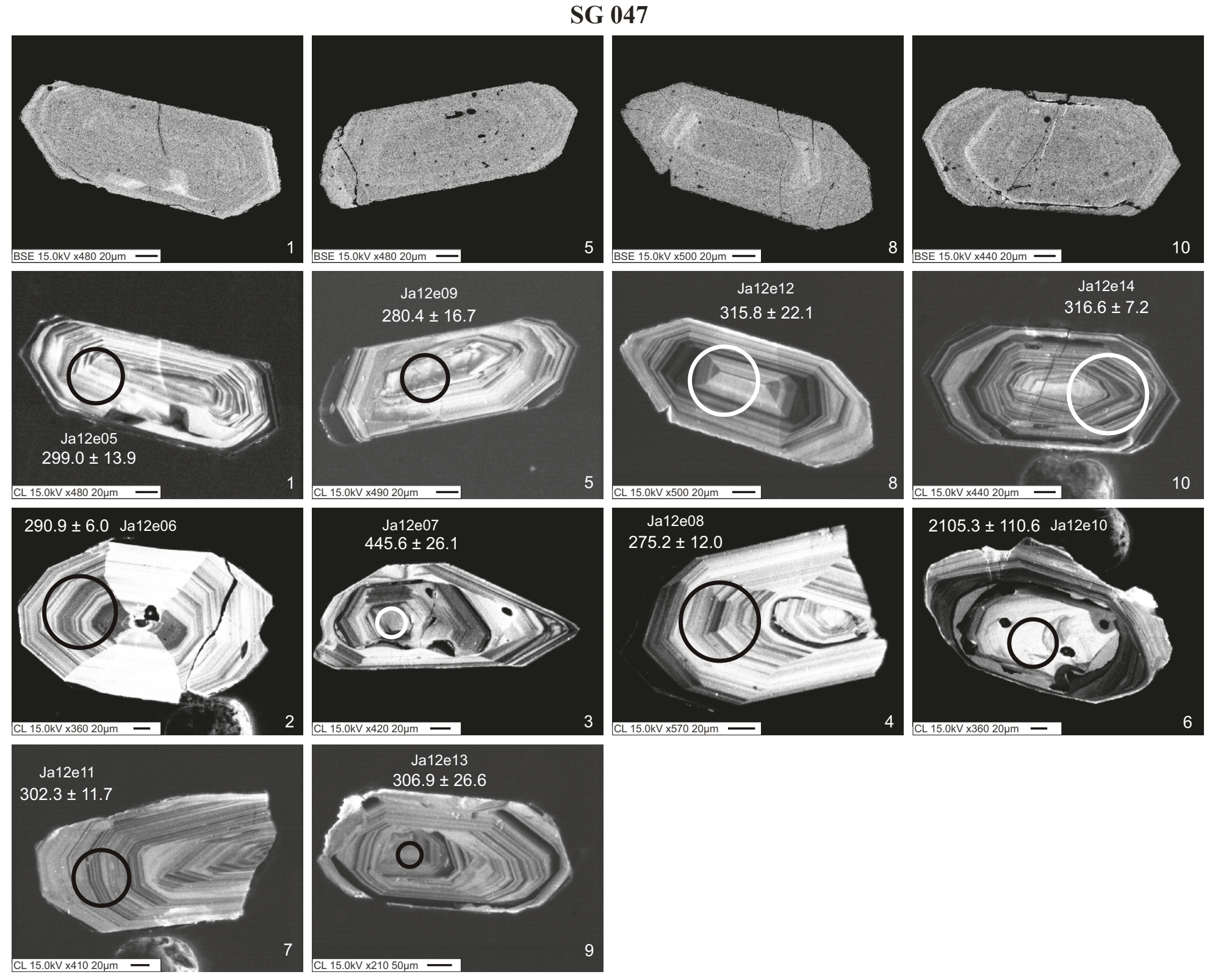

\section{SG 051}
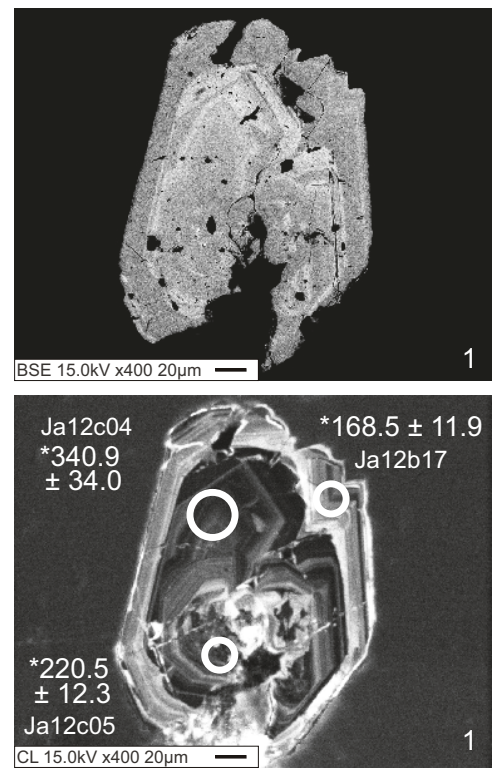
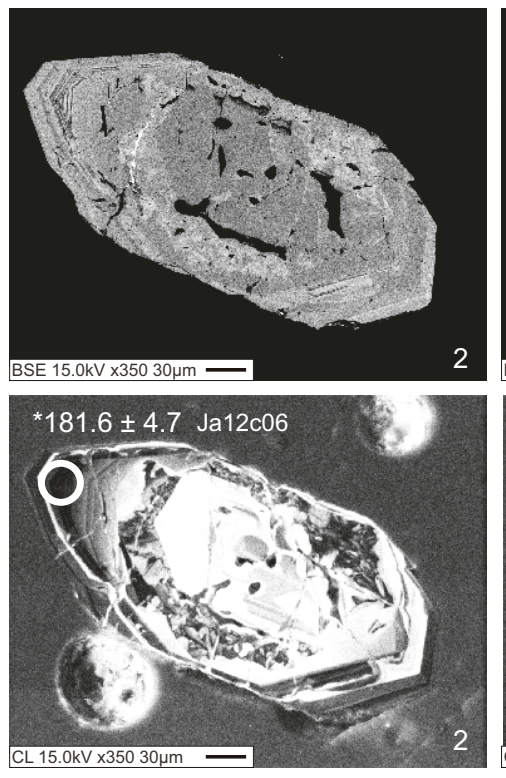
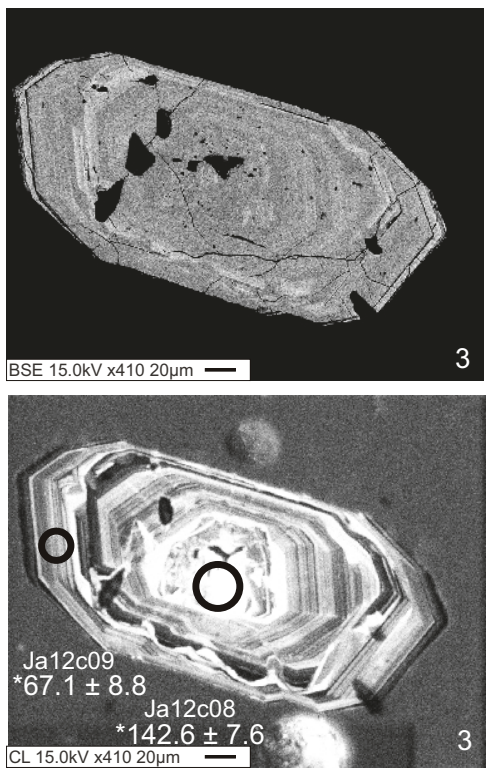

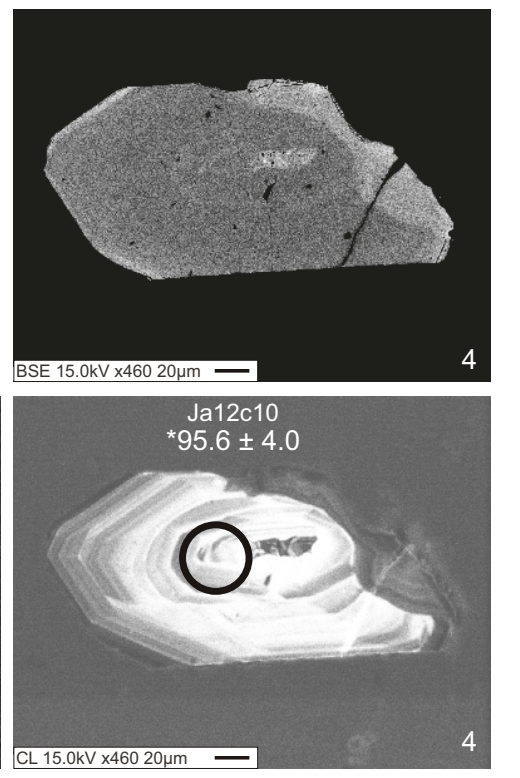




\section{SG 051-continued}
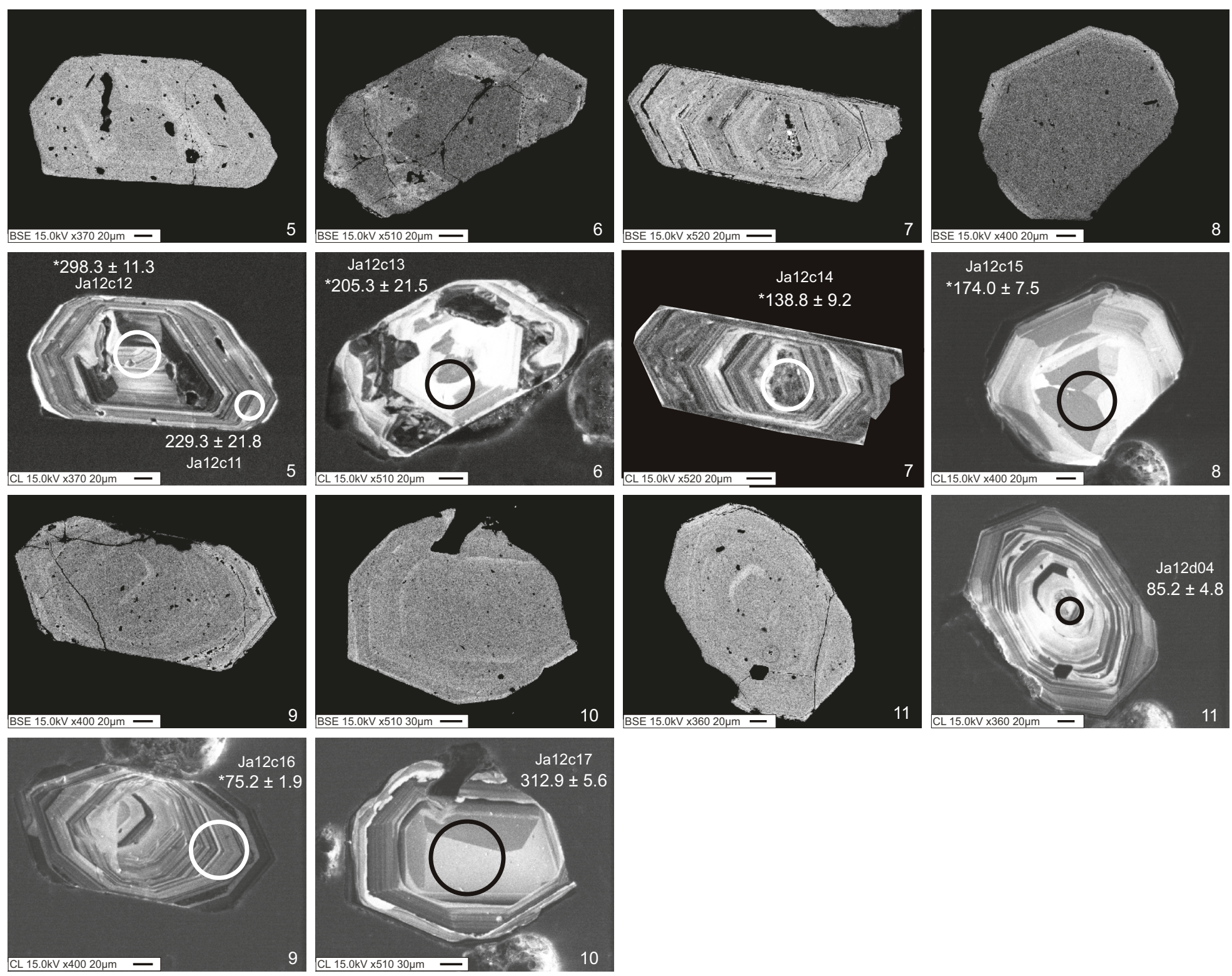

SG 052
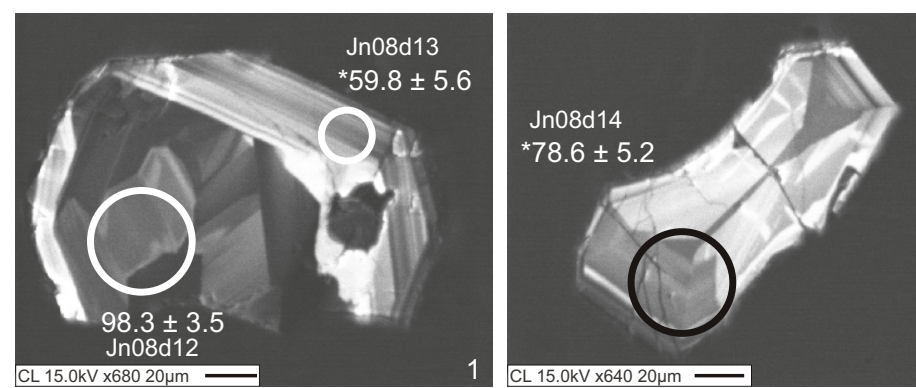

1

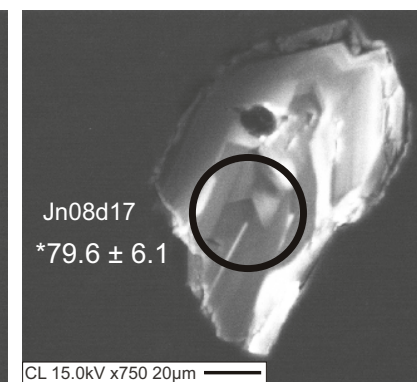

5
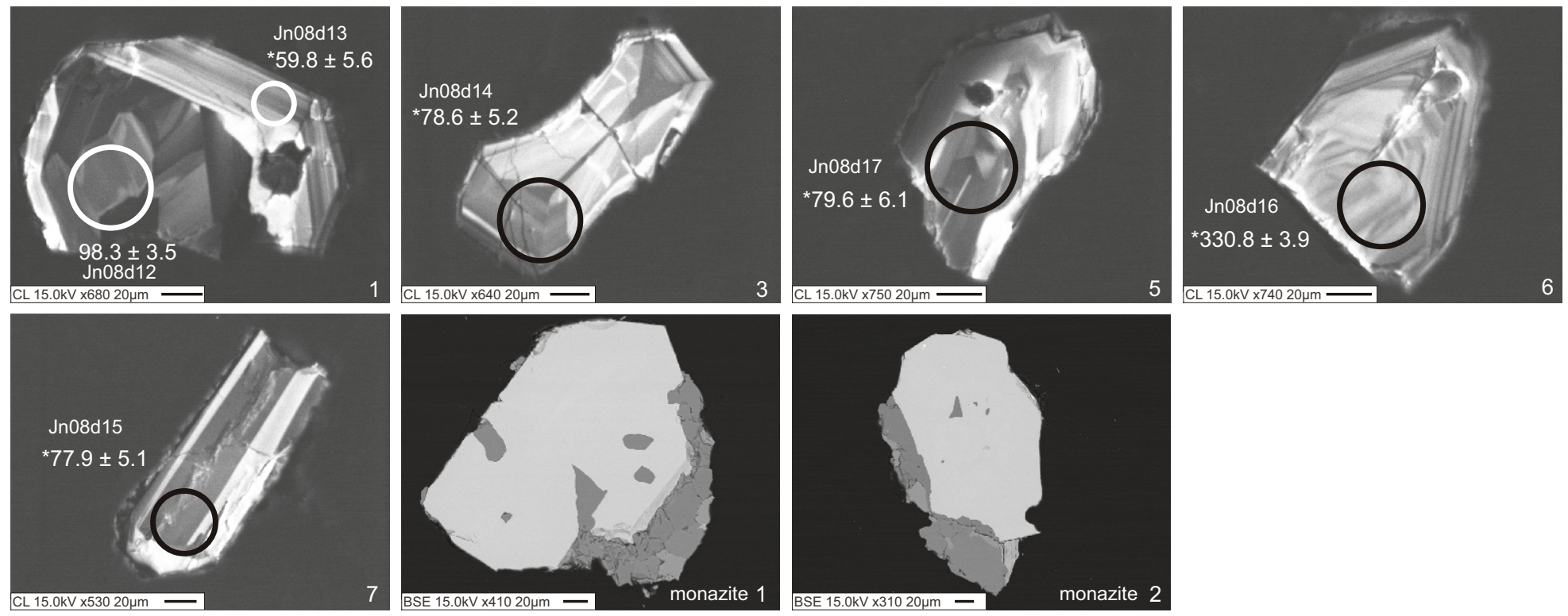


\section{SG 053}
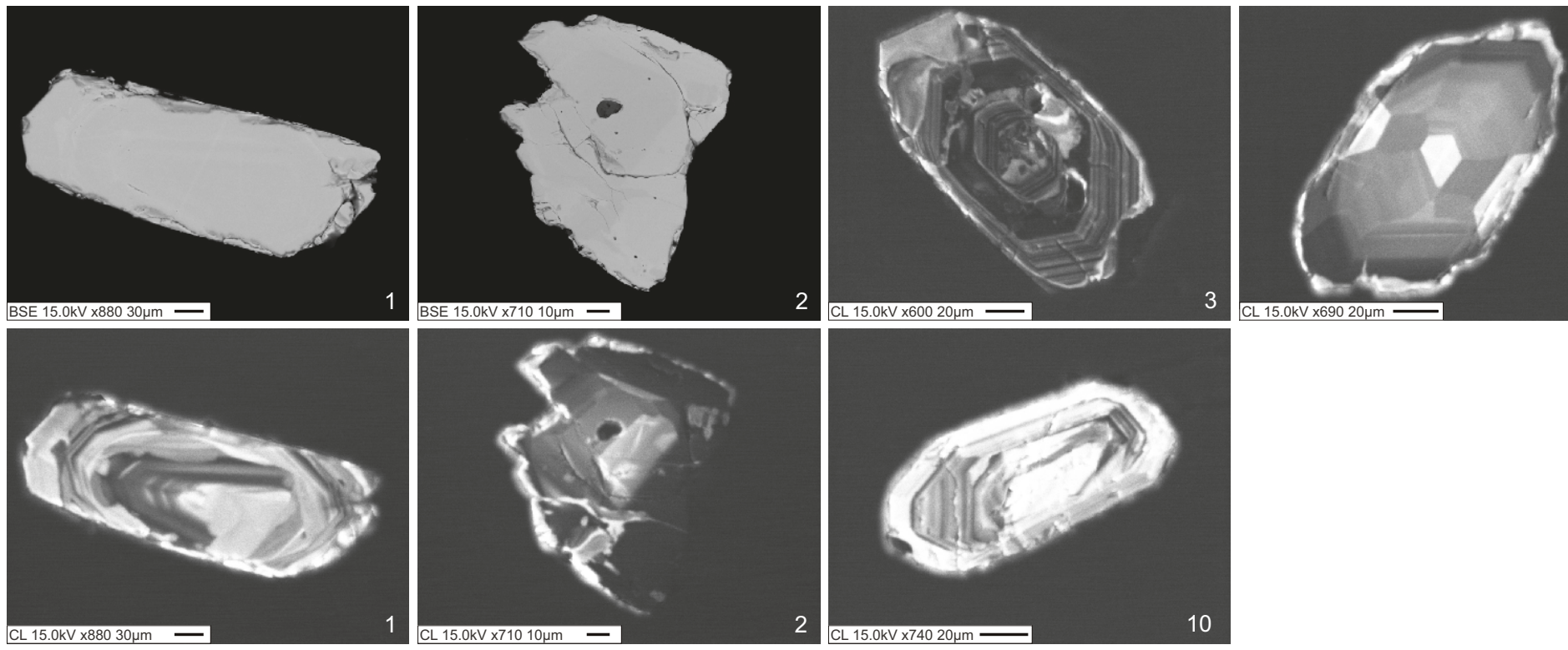

\section{CL}

SG 057
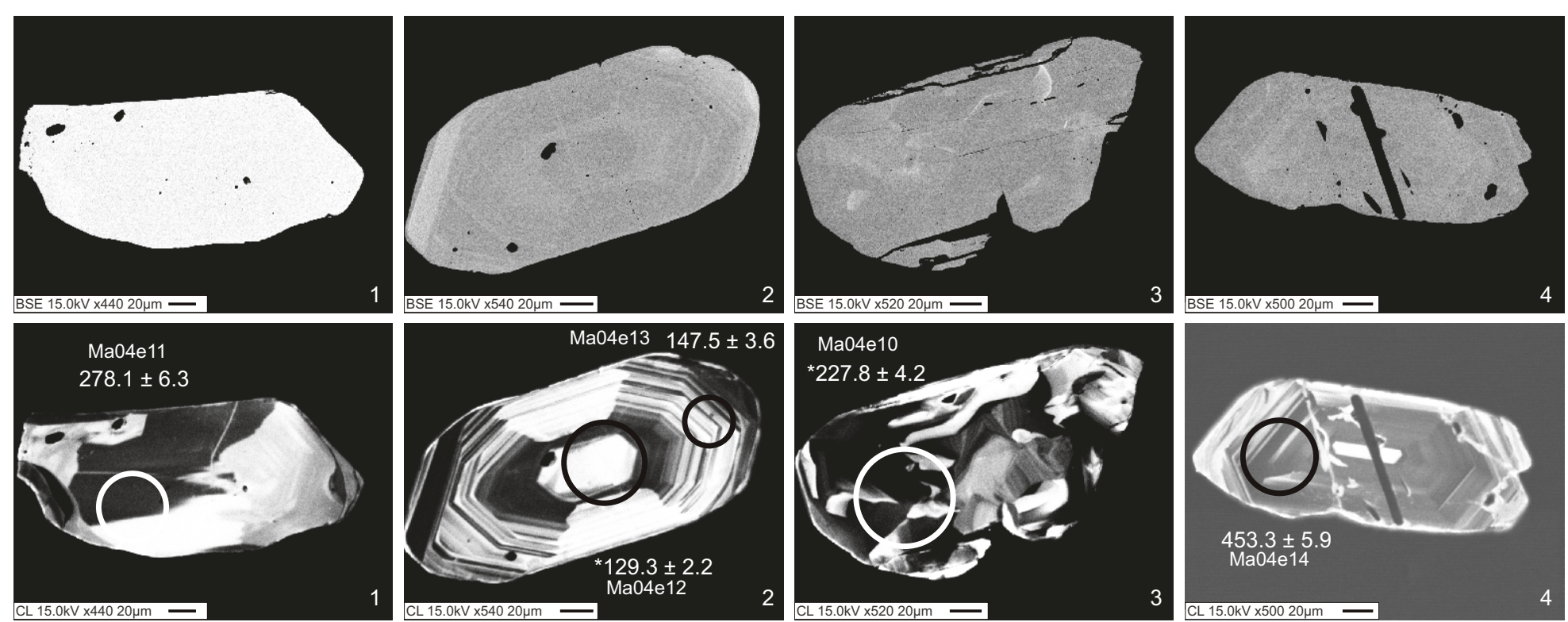

$453.3 \pm 5.9$

Ma04e14

3 CL 15.0kV x500 20um -
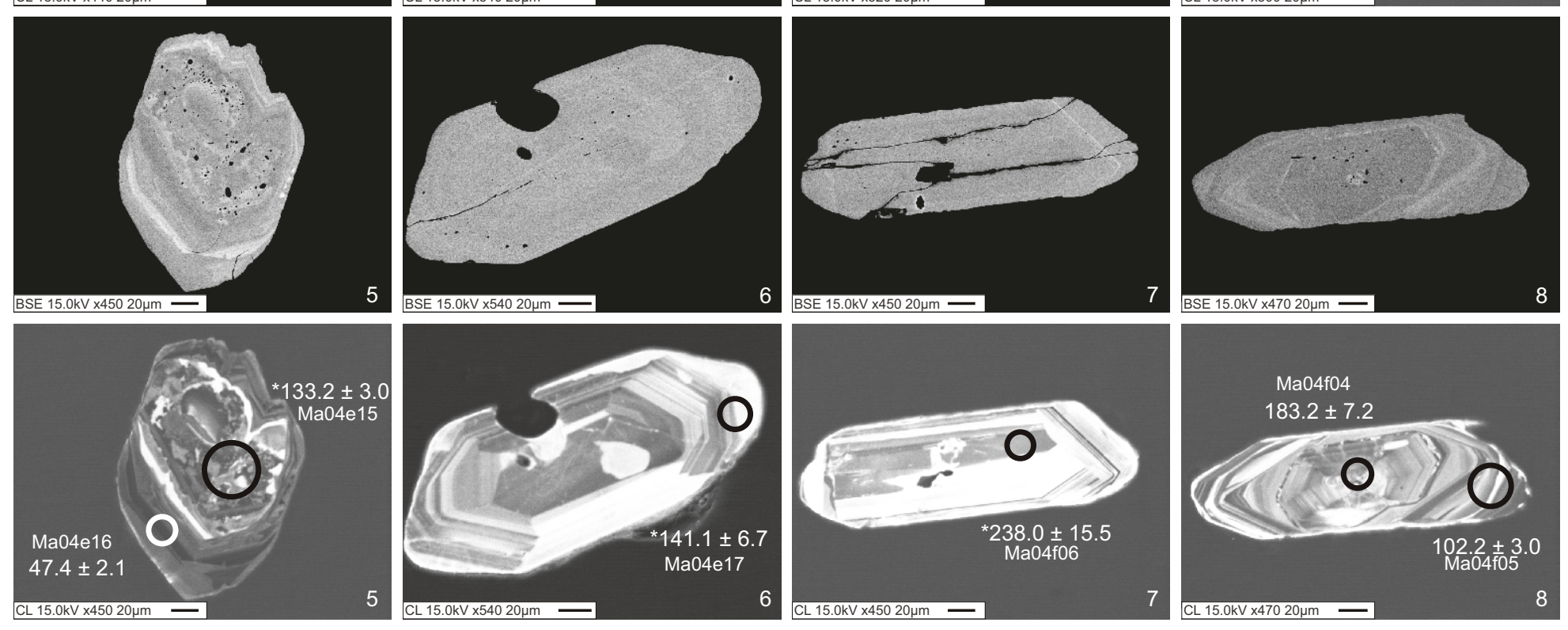


\section{SG 063}
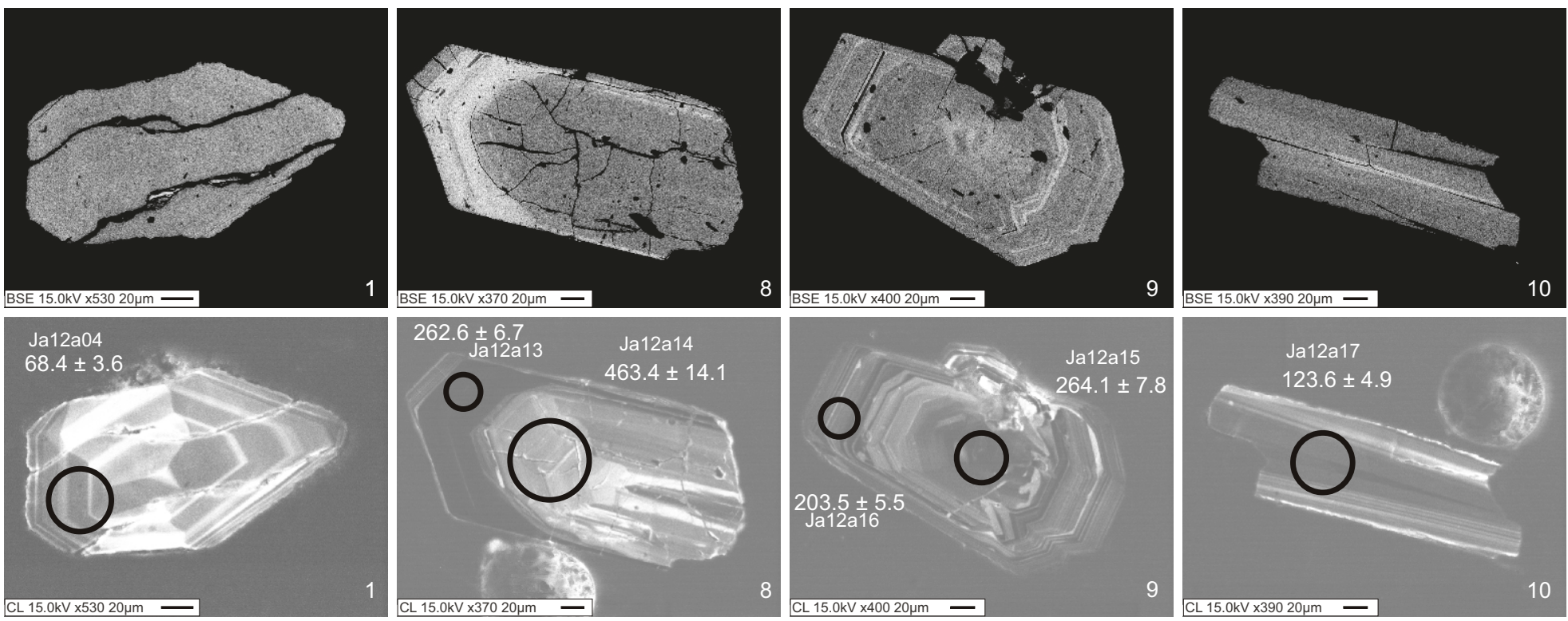

CL 15.0kV ×530 20um -
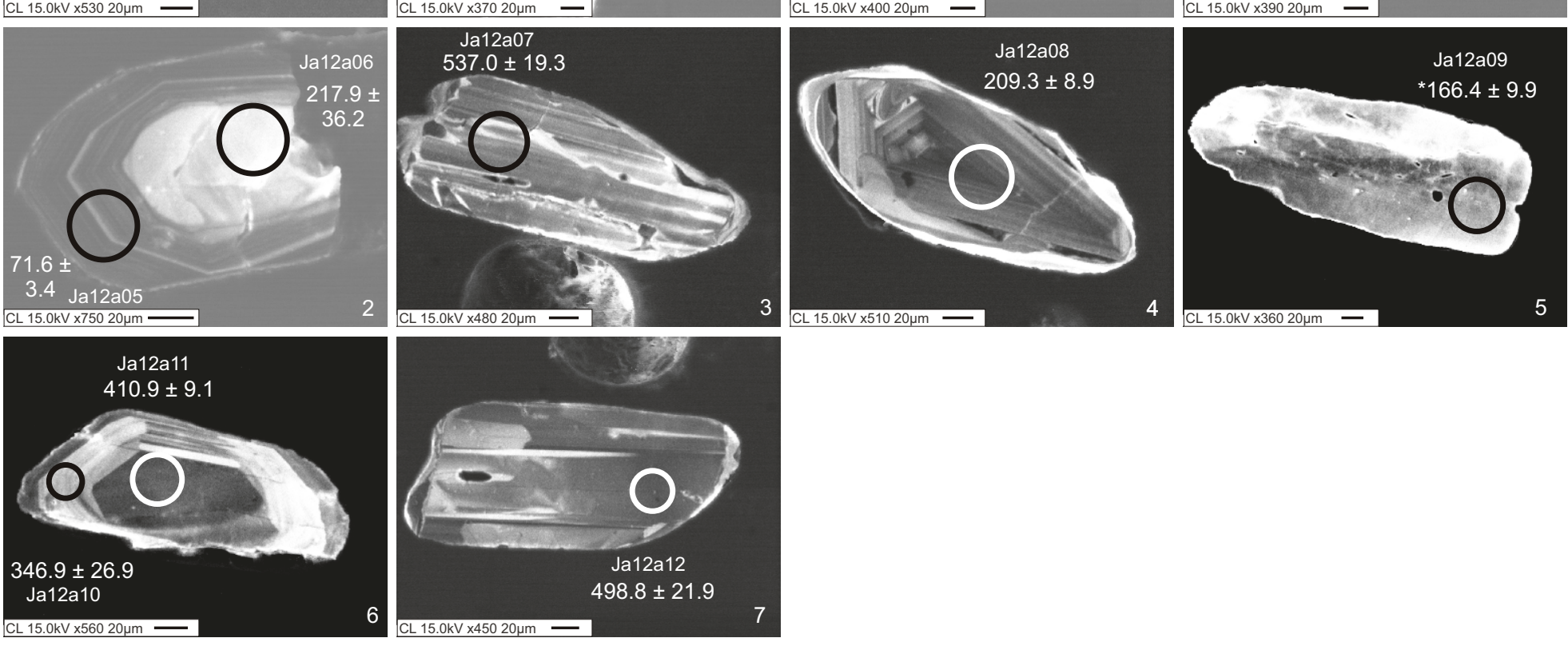

SG 066
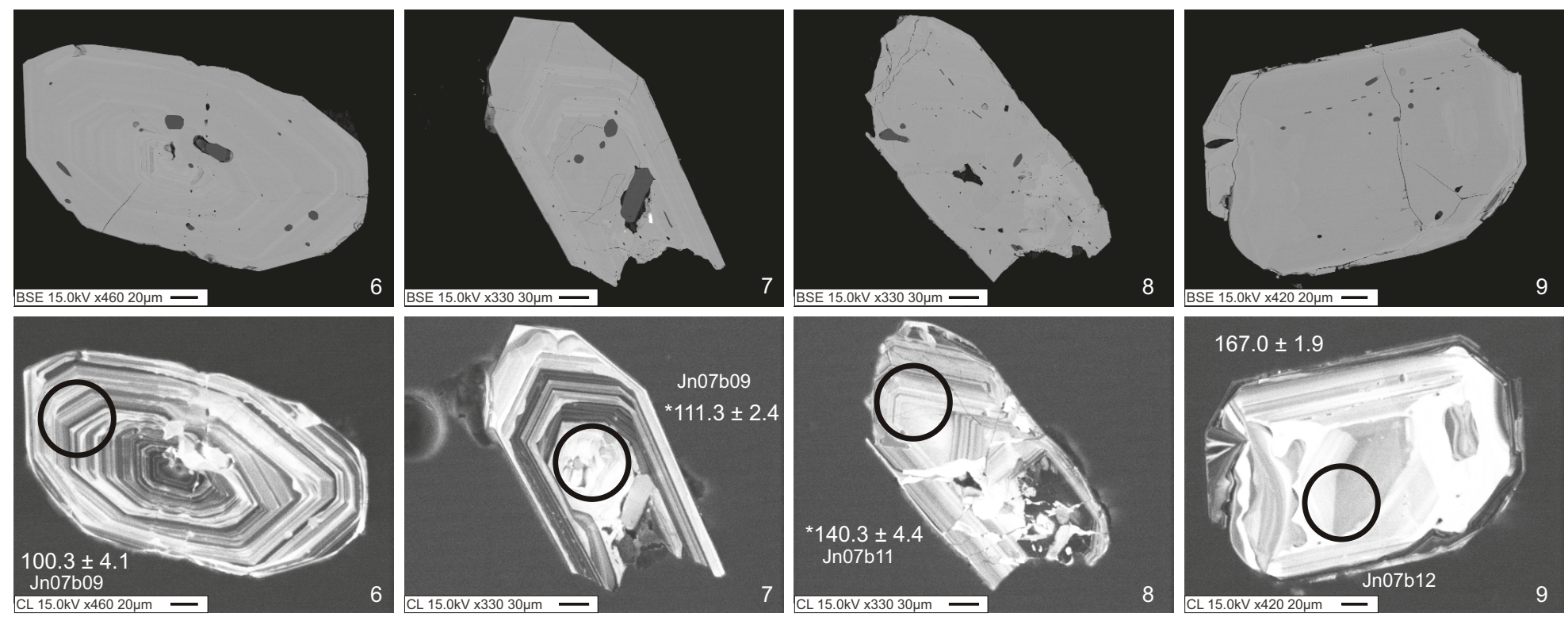


\section{SG 066-continued}
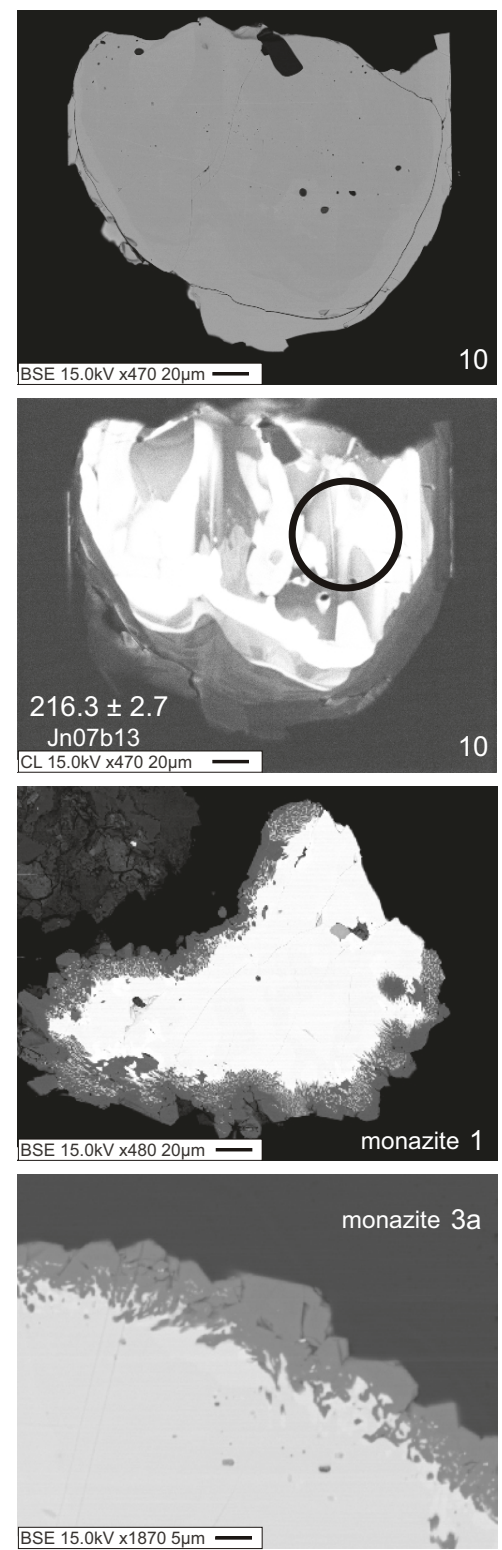

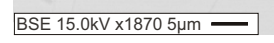

10
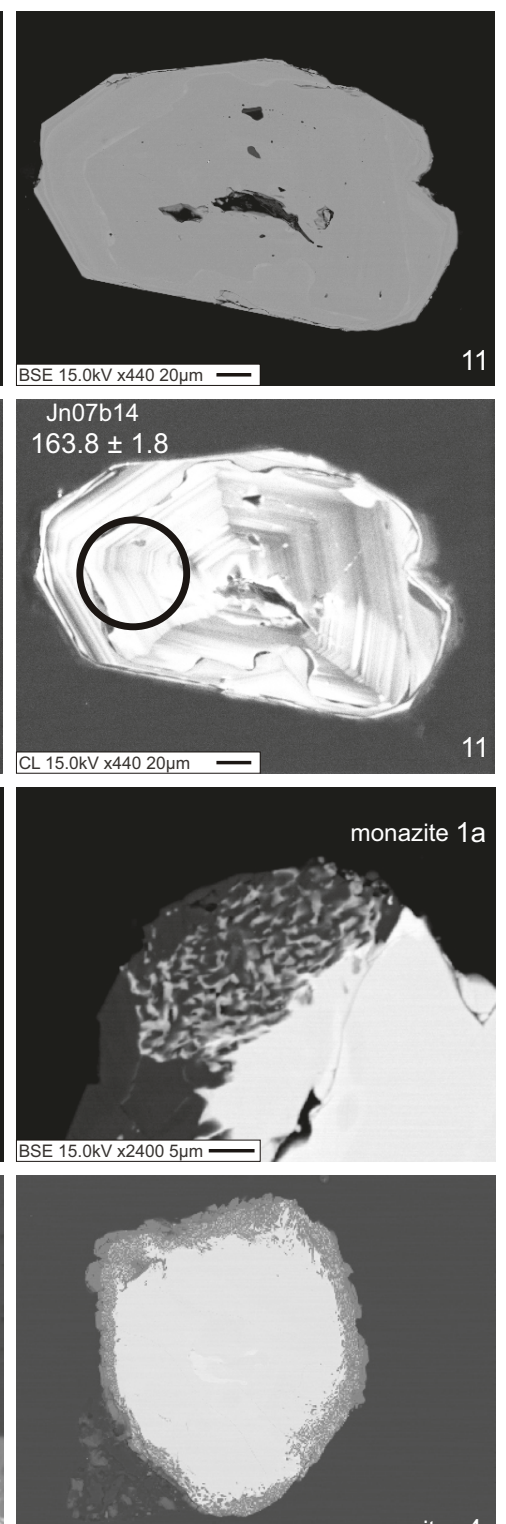

monazite 4
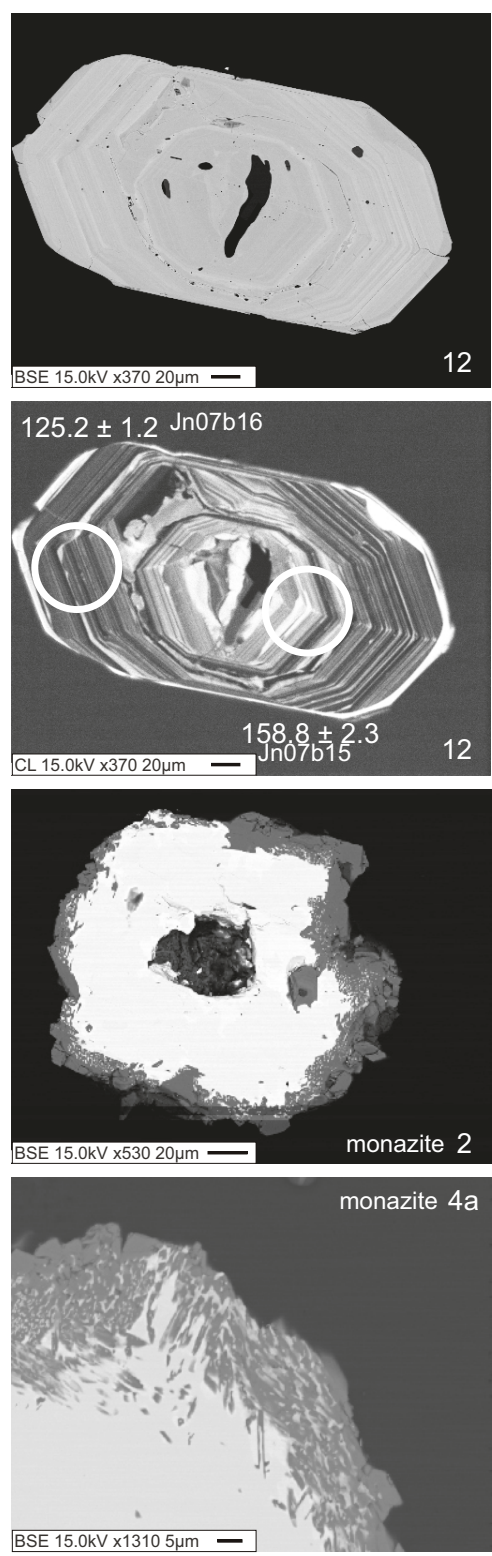

monazite 4 a

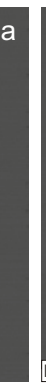

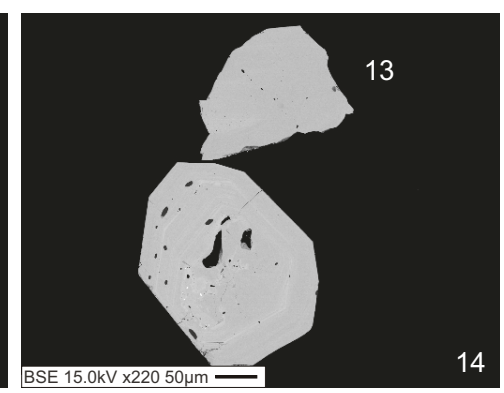
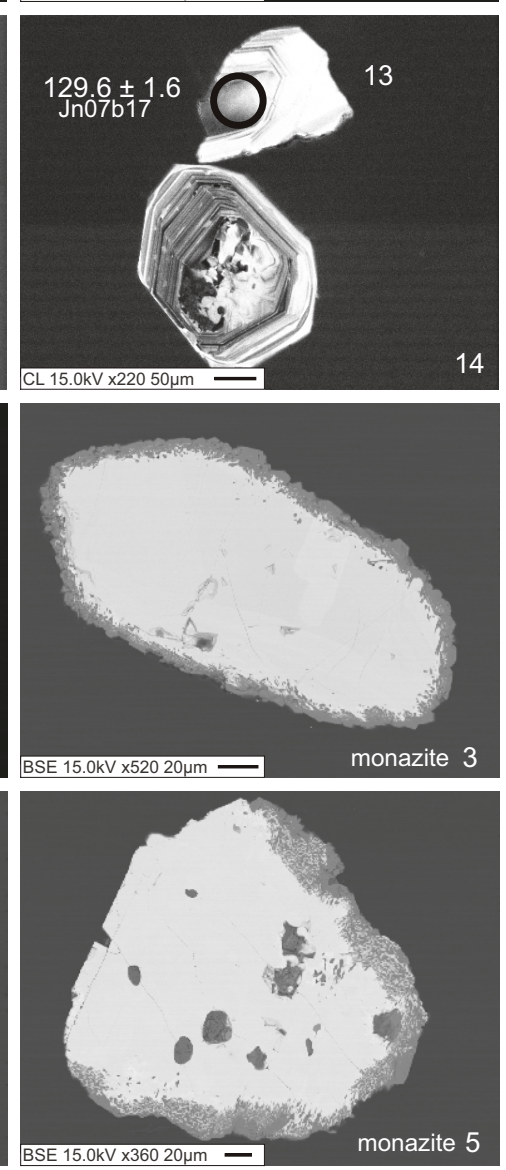

\section{SG 068}
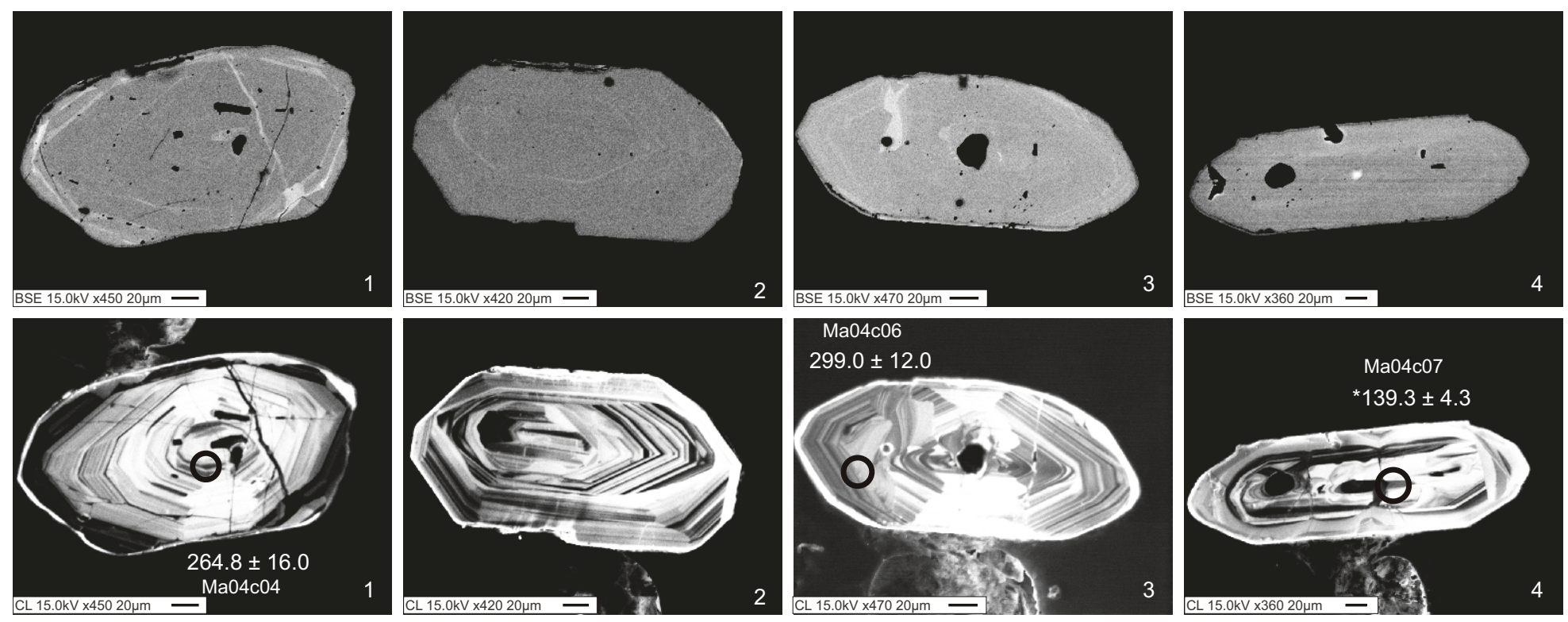


\section{SG 068-continued}
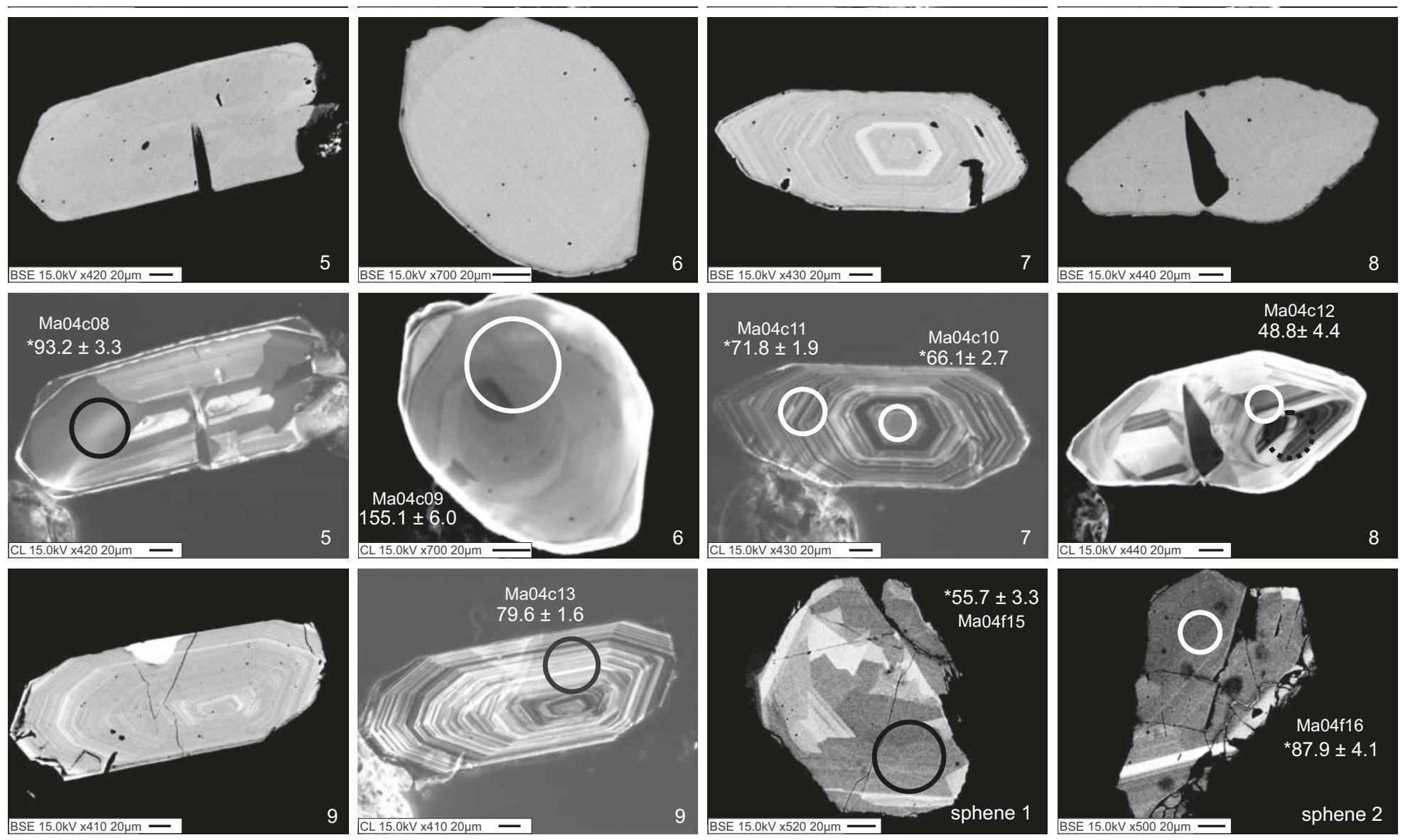

SG 069
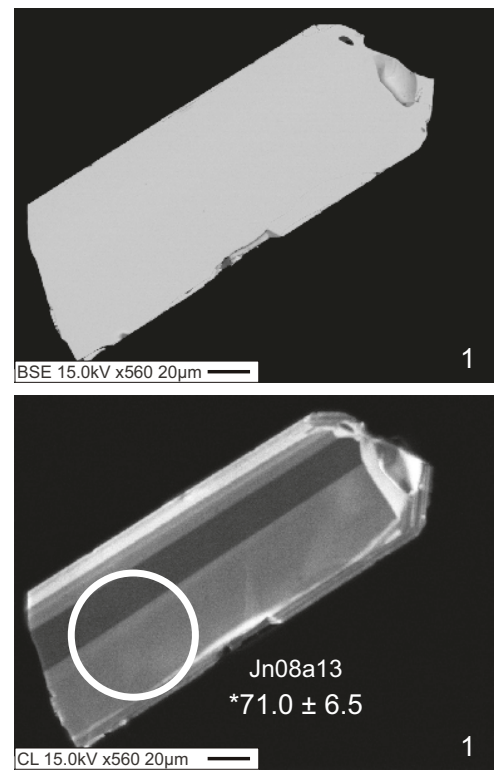
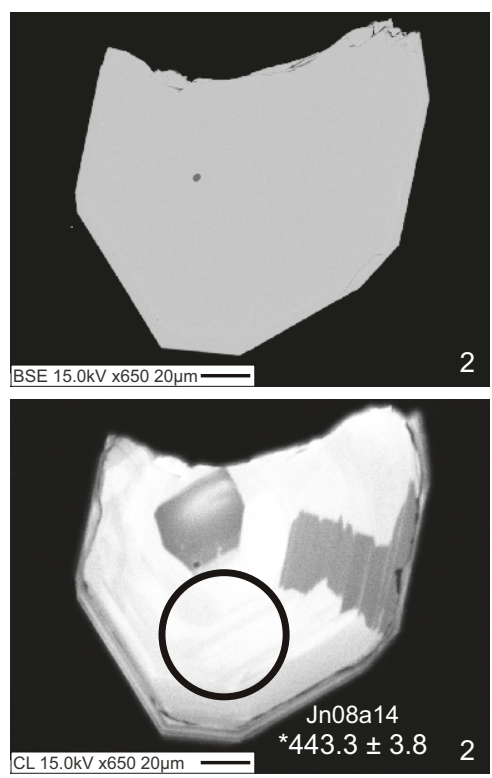
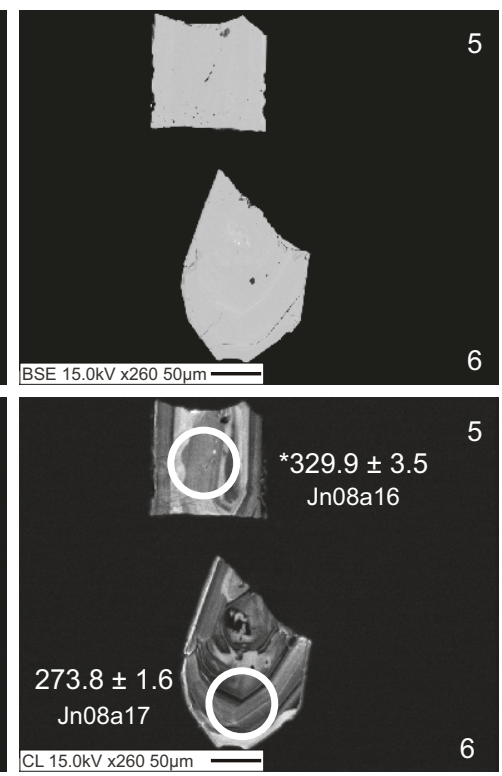
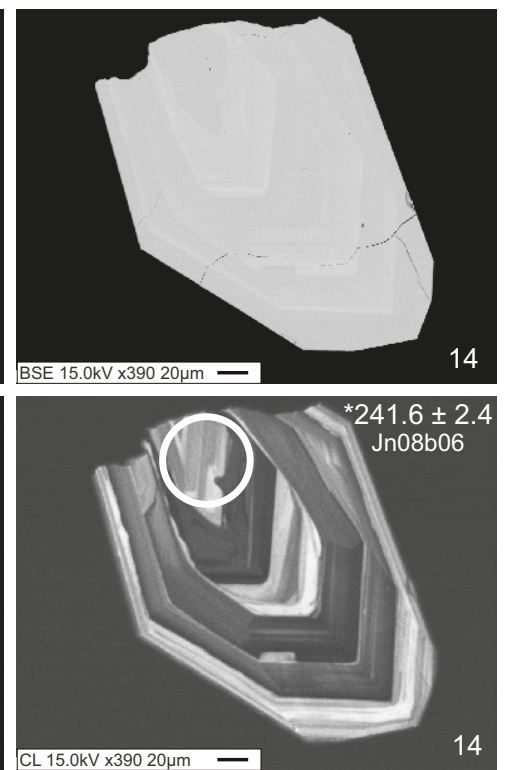


\section{SG 069-continued}
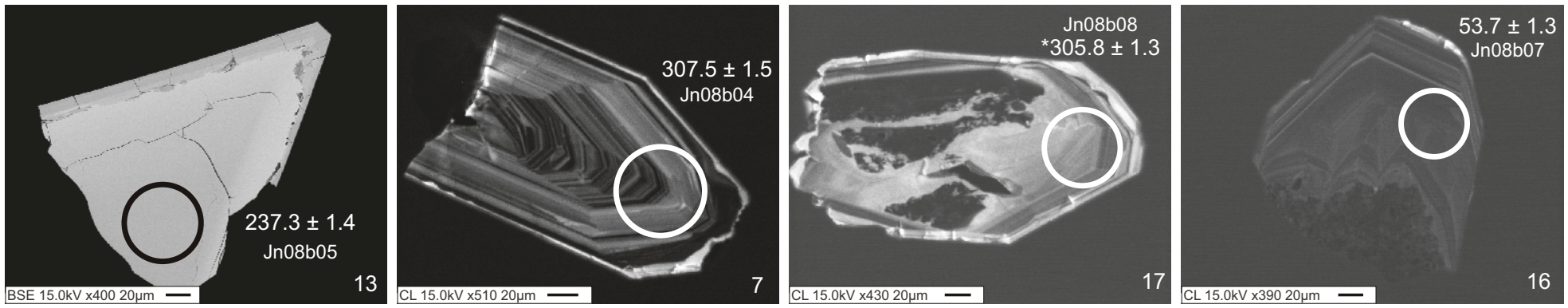

SG 070
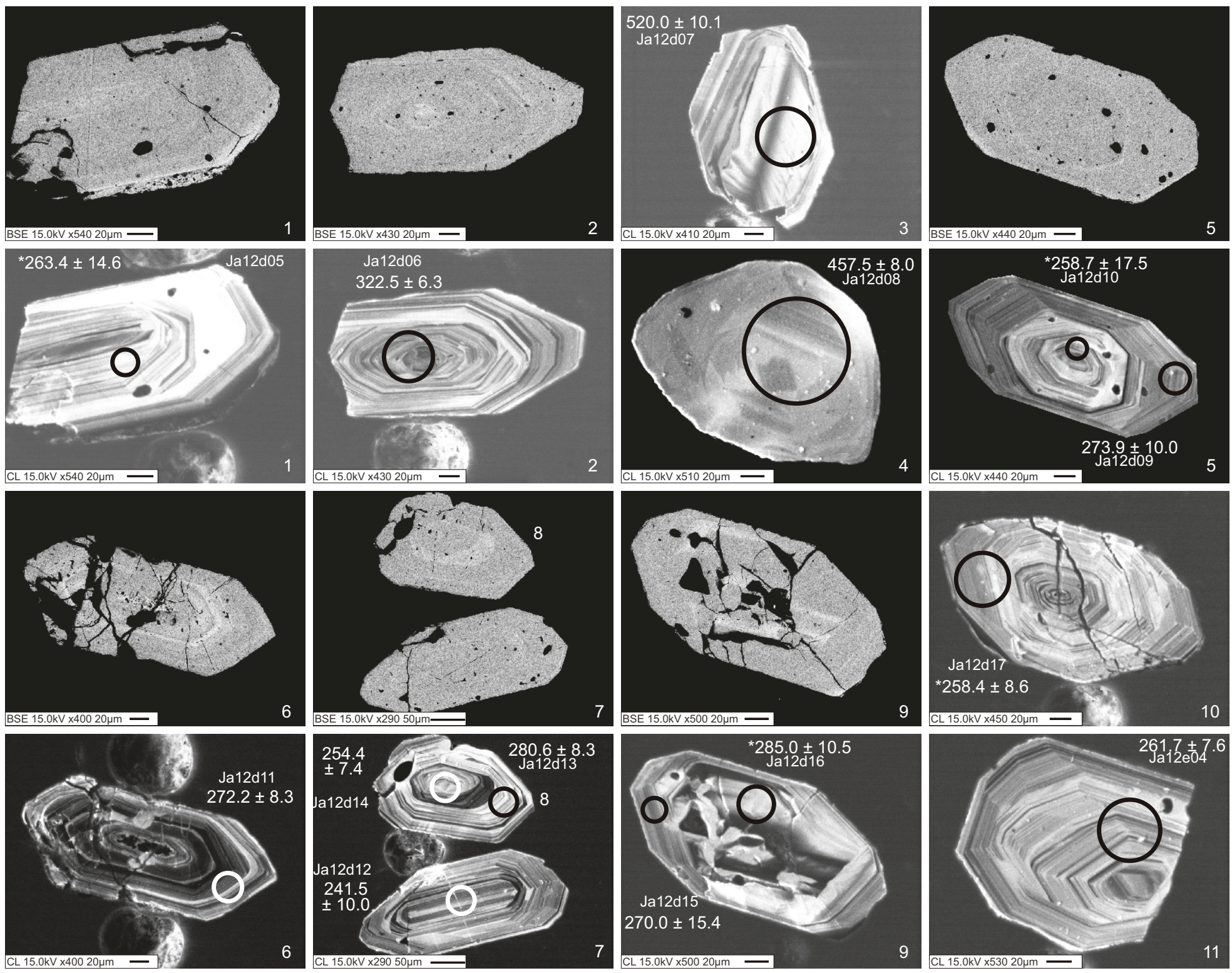


\section{SG 078}
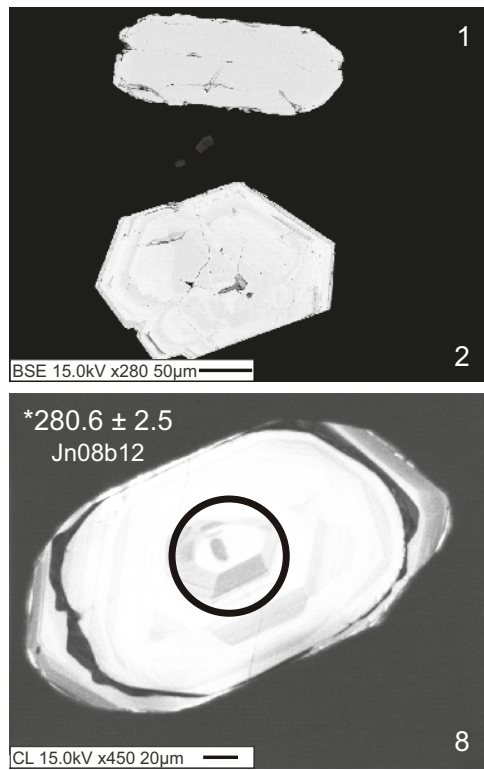

2.

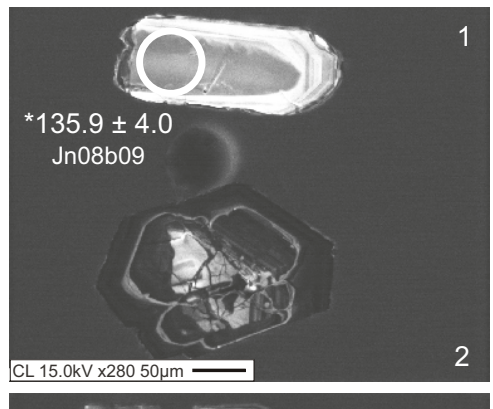

8

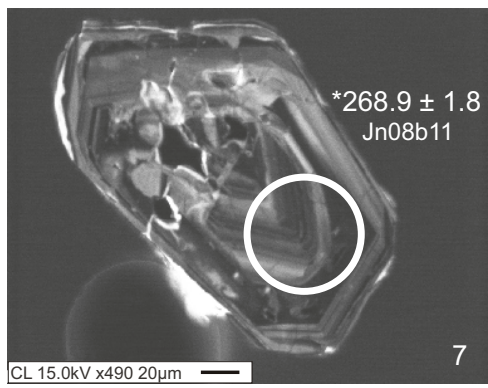

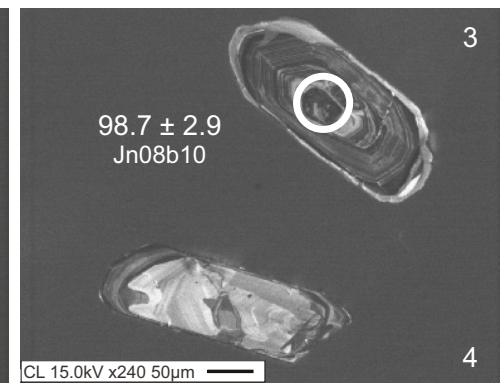

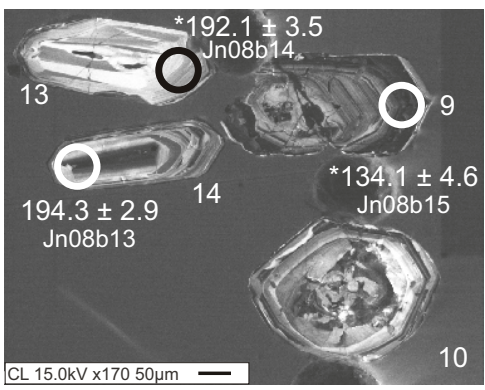

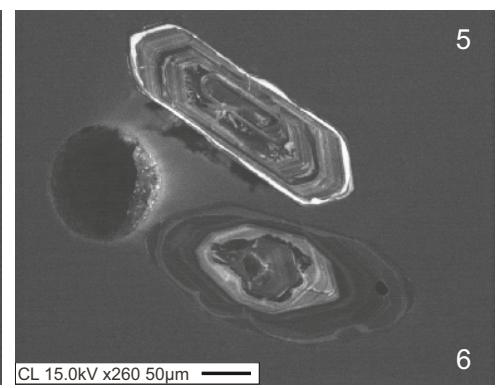

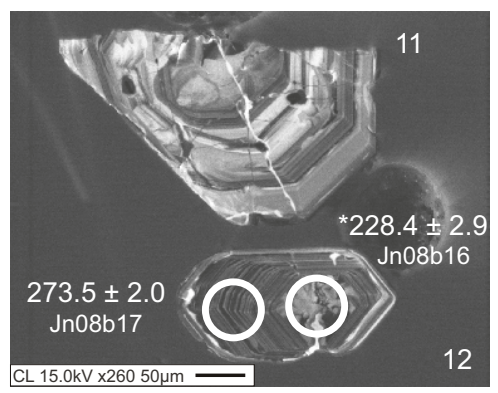

\section{SG 079}
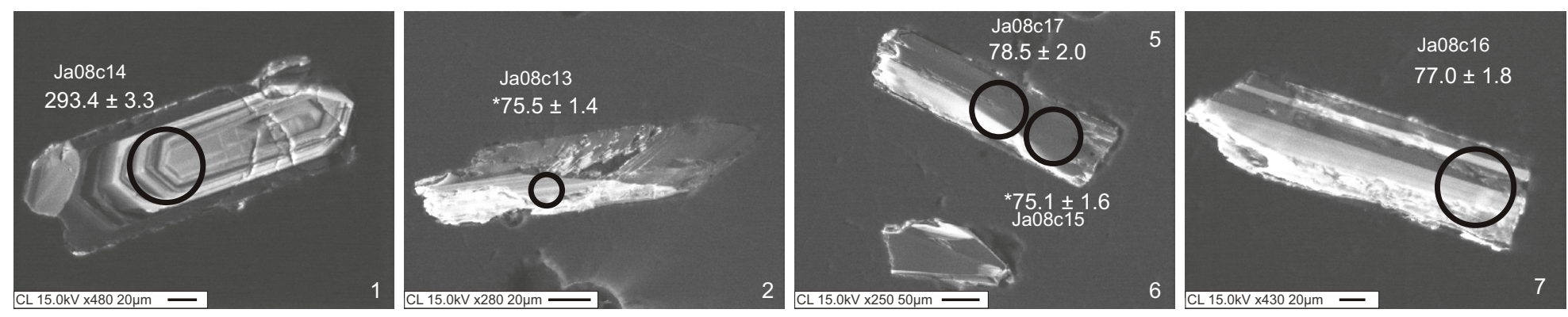

\section{SG 085}
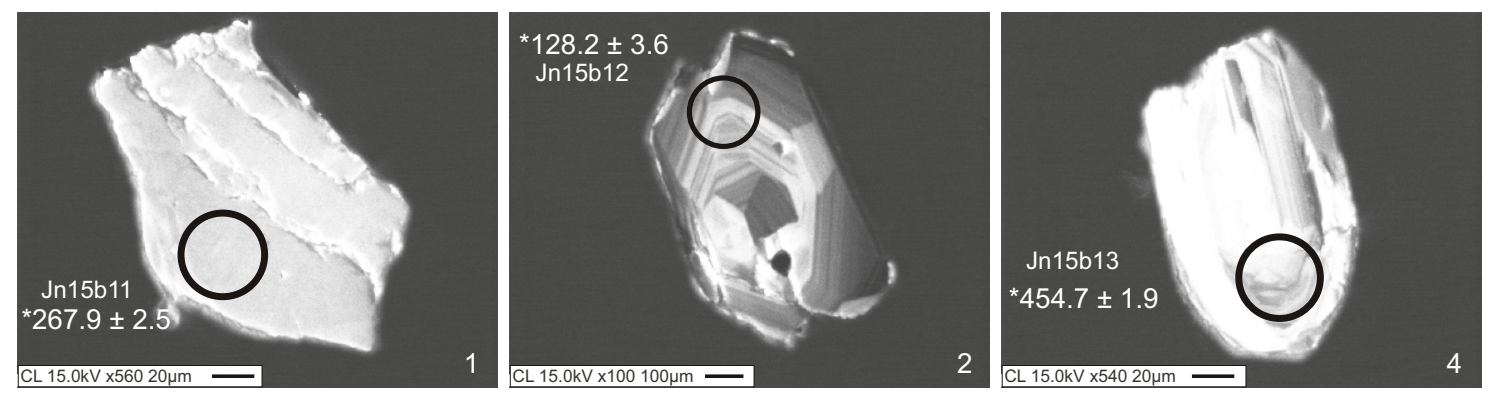

\section{SG 090}
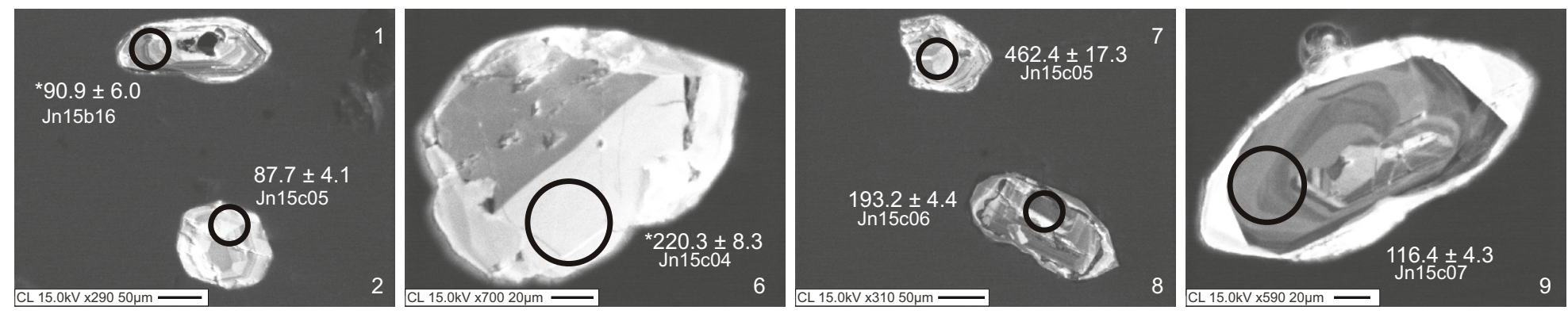
SG 102d
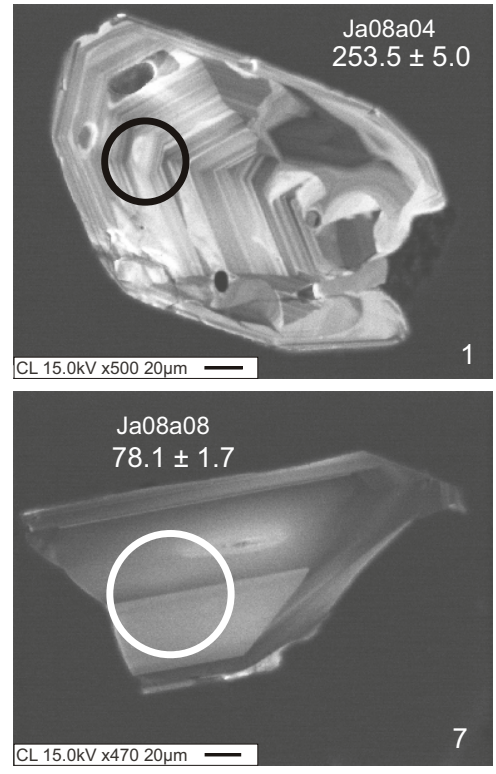

CL 15.0kV x470 20um -
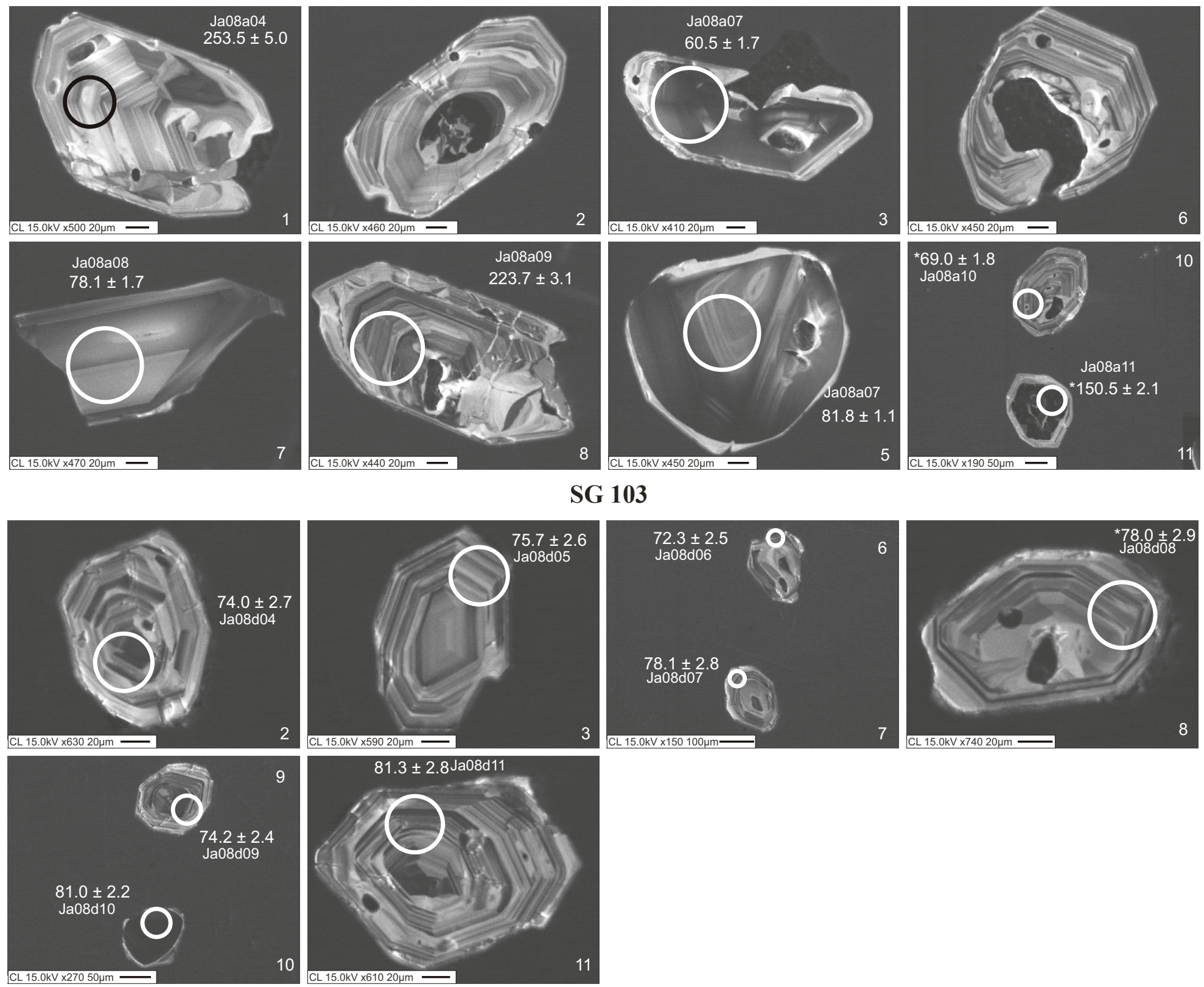

SG 103
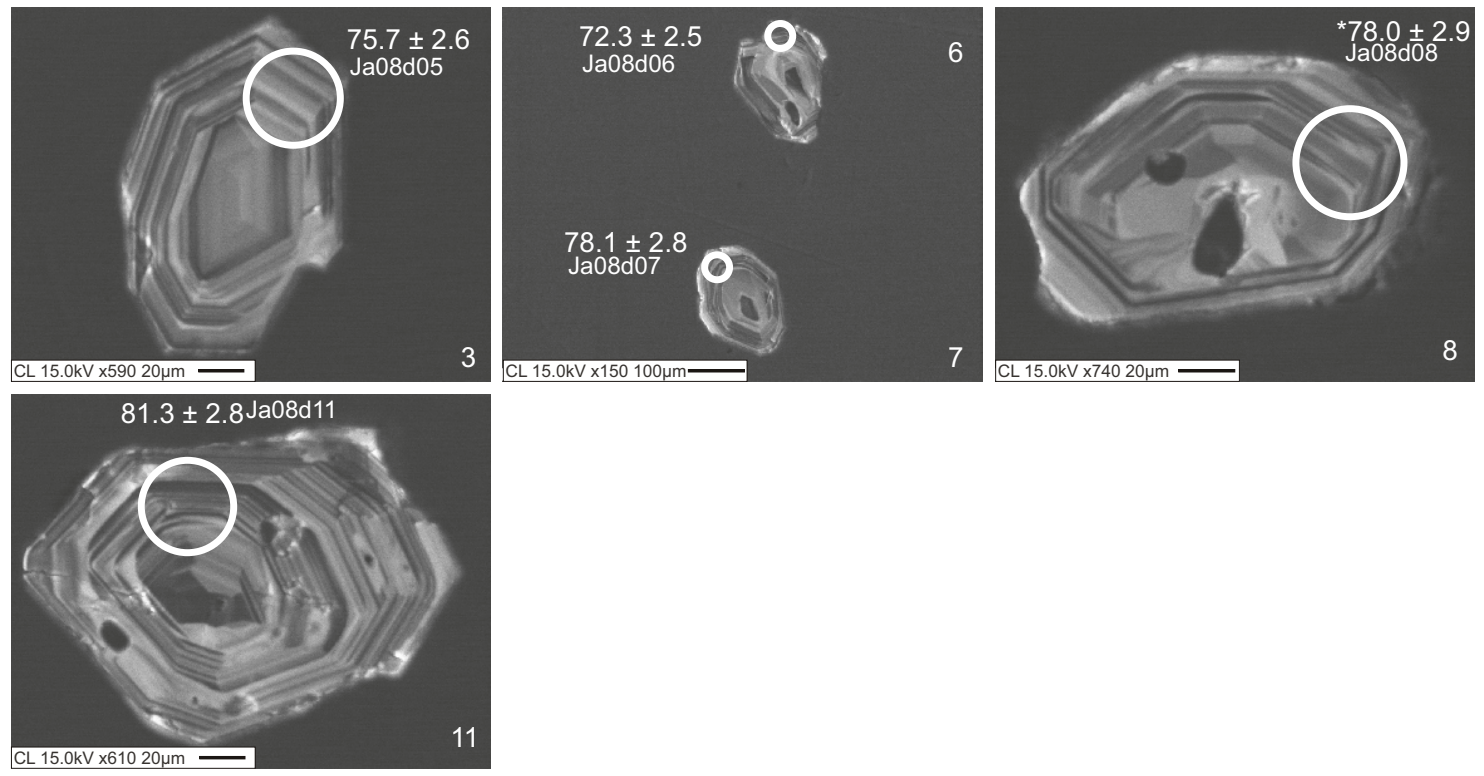

\section{St 25}
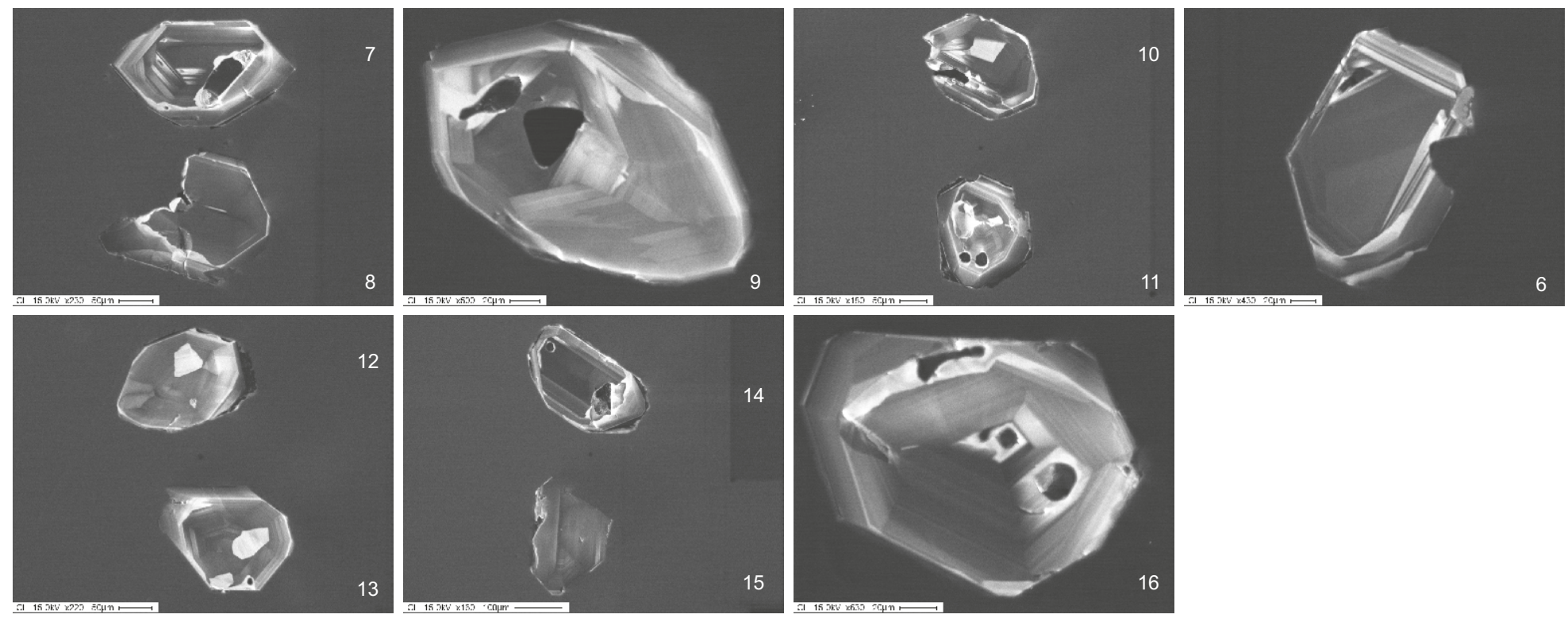